\title{
Holocene vegetation dynamics and disturbance regimes in north Patagonia Argentina $\left(40^{\circ} \mathrm{S}\right)$
}

\author{
Dissertation \\ for the award of the degree \\ "Doctor of Philosophy" (Ph.D. Division of Mathematics and Natural Sciences) \\ of the Georg-August-Universität Göttingen
}

within the doctoral program Biodiversity and Ecology

Submitted by

Valentina Andrea Álvarez Barra

from Santiago de Chile

Göttingen, April 2020 


\section{Thesis Committee}

Prof. Dr. Hermann Behling

(Dept. Palynology and Climate Dynamics / A.-v.-H. Institute for Plant Sciences)

Prof. Dr. Frank Schäbitz (From July 2019 to April 2020)

(Dept. of Education in Mathematics and Natural Science / Institute of Geography and Education, University of Cologne, Germany)

Prof. Dr. Erwin Bergmeier (From July 2019 to April 2020)

(Dept. of Vegetation and Phytodiversity Analysis / A.-V.-H. Institute for Plant Sciences)

Dr. Thomas Giesecke (from April 2016 to July 2019)

(Dept. Palynology and Climate Dynamics / A.-v.-H. Institute for Plant Sciences; Department of Physical Geography, Faculty of Geosciences, Utrecht University, Netherlands)

Dr. Sonia L. Fontana (From April 2016 to July 2019)

(Dept. Palynology and Climate Dynamics / A.-v.-H. Institute for Plant Sciences)

\section{Members of the Examination Board}

Prof. Dr. Hermann Behling

(Dept. Palynology and Climate Dynamics / A.-v.-H. Institute for Plant Sciences)

Prof. Dr. Frank Schäbitz

(Dept. of Education in Mathematics and Natural Science / Institute of Geography and Education, University of Cologne, Germany)

Prof. Dr. Erwin Bergmeier

(Dept. of Vegetation and Phytodiversity Analysis / A.-V.-H. Institute for Plant Sciences)

Prof. Dr. Daniela Sauer

(Department of Geography - Section Physical Geography)

Prof. Dr. Michaela Dippold

(Dept. for Crop Sciences / Faculty of Agriculture)

Date of the oral examination: 29.04 .2020 
Dedicated to my parents, Judith and Nelson and in memory of my grandmother Otilia, who passed away one week before I started this journey 
Vino a quemar el bosque, a incendiar las entrañas de la tierra, vino a sembrar un saco de fréjoles y a dejarnos una herencia helada: la eternidad del hambre.

Rozó con fuego el alto nivel de los mañíos, el baluarte del roble, la ciudad del raulí, la rumorosa colmena de los ulmos, y ahora desde las raíces quemadas, se va la tierra, nada la defiende, bruscos socavones, heridas que ya nada ni nadie puede borrar del suelo: asesinada fue la tierra mía, quemada fue la copa, originaria.

Oda a la erosión en la Provincia de Malleco (1956).

Pablo Neruda. Nobel prize for Literature, 1971

En montañas me crié

con tres docenas alzadas.

Parece que nunca, nunca,

aunque me escuche la marcha,

las perdí, ni cuando es día

ni cuando es noche estrellada,

$y$ aunque me vea en las fuentes

la cabellera nevada,

las dejé ni me dejaron

como a hija trascordada.

$Y$ aunque me digan el mote

de ausente y de renegada,

me las tuve y me las tengo

todavía, todavía,

y me sigue su mirada.

Montañas Mías. Poema de Chile (1967)

Gabriela Mistral. Nobel Prize for Literature 1945. 


\section{Table of content}

$\begin{array}{ll}\text { Summary } & 1\end{array}$

List of Figures and Tables $\quad 2$

$\begin{array}{lr}\text { Preface } & 6\end{array}$

Chapter 1: Introduction $\quad 8$

1.1 The Lanín National Park $\quad 8$

1.2 Climate $\quad 9$

$\begin{array}{ll}1.3 \text { The three dominant vegetation of } & 11\end{array}$

Northwestern Patagonia

1.4 The vegetation of the Lanín National Park 13

$\begin{array}{ll}\text { References } & 15\end{array}$

Chapter 2: Ecology and current investigations on Nothofagus alpina and Nothofagus obliqua

2.1 General overview of the ecology of Nothofagus alpina 18

2.2 General overview of the ecology of Nothofagus obliqua 20

2.3 Summary of the palynological records with Nothofagus alpina-Nothofagus obliqua presence in southern South America $\quad 22$

2.4 Some examples of genetic studies on Nothofagus alpina and Nothofagus obliqua 25

$\begin{array}{ll}\text { References } & 26\end{array}$

Chapter 3: Disturbance processes in northern Patagonia

$\begin{array}{ll}3.1 \text { Disturbance } & 29\end{array}$

3.2 Disturbance agents in northern Patagonia $\quad 29$

$\begin{array}{ll}3.3 \text { Volcanism and vegetation responses in Patagonia } & 30\end{array}$

3.4 Fire regimes in Patagonia $\quad 34$

$\begin{array}{ll}\text { References } & 37\end{array}$

Chapter 4: Palaeoecology and Palynology

4.1 What is palaeoecology? General concepts 40

4.2 Links between palaeoecology, ecology, and nature 40

conservation

4.3 Palynology and past vegetation reconstructions $\quad 41$

References $\quad 43$

Chapter 5: Late Holocene vegetation dynamics and disturbance regimes in north Patagonia Argentina $\left(40^{\circ} \mathrm{S}\right)$

$\begin{array}{ll}\text { Abstract } & 46\end{array}$

$\begin{array}{ll}5.1 \text { Introduction } & 46\end{array}$

$\begin{array}{ll}5.2 \text { Modern environmental setting } & 48\end{array}$

$\begin{array}{lr}5.3 \text { Material and Methods } & 50\end{array}$

$\begin{array}{ll}5.4 \text { Results } & 53\end{array}$

5.4.1 Chronology, Lithology, and Loss on Ignition 53

5.4.2 Avutarda and Bruja pollen record and Fire History of Lake Bruja 56

$\begin{array}{ll}\text { 5.4.3 PCA and RDA } & 59\end{array}$

$\begin{array}{ll}5.5 \text { Discussion } & 64\end{array}$

5.5.1 Vegetation history and population increase of Nothofagus alpina 64

5.5.2 Disturbance history 66

$\begin{array}{ll}\text { 5.5.3 Human impact } & 69\end{array}$

$\begin{array}{ll}5.6 \text { Conclusions } & 70\end{array}$

$\begin{array}{ll}\text { References } & 71\end{array}$ 
Chapter 6: 11000 years of vegetation dynamics, fire regimes, and volcanic activity near Lake Lácar Basin, Lanín National Park, Province of Neuquén, Argentina

$\begin{array}{ll}\text { Abstract } & 79\end{array}$

$\begin{array}{ll}6.1 \text { Introduction } & 79\end{array}$

6.2 Study area $\quad 81$

6.2.1 Climate and topography $\quad 81$

6.2.2 Vegetation 81

6.2.3 Study site 83

6.3 Material and methods $\quad 84$

$\begin{array}{ll}6.4 \text { Results } & 87\end{array}$

$\begin{array}{ll}\text { 6.4.1 Chronology and stratigraphy } & 87\end{array}$

$\begin{array}{ll}\text { 6.4.2 Pollen record } & 90\end{array}$

6.4.3 Numerical analysis of data $\quad 92$

$\begin{array}{ll}\text { 6.4.4 Fire record } & 97\end{array}$

$\begin{array}{ll}6.5 \text { Discussion } & 99\end{array}$

6.5.1 Vegetation reconstruction $\quad 99$

6.5.2 Disturbance regimes and their effects on the local vegetation dynamics nearby

$\begin{array}{ll}\text { Lake Vizcacha } & 102\end{array}$

$\begin{array}{ll}6.6 \text { Conclusions } & 107\end{array}$

$\begin{array}{ll}\text { References } & 109\end{array}$

Chapter 7: Nothofagus obliqua pollen type in southern South America: A revision of palynological records and Postglacial history

$\begin{array}{ll}\text { Abstract } & 118\end{array}$

$\begin{array}{ll}7.1 \text { Introduction } & 118\end{array}$

$\begin{array}{ll}7.2 \text { Environmental setting } & 120\end{array}$

$\begin{array}{ll}\text { 7.2.1 Topography and climate of the study } & 120\end{array}$

site

$\begin{array}{ll}\text { 7.2.2 Vegetation } & 123\end{array}$

$\begin{array}{ll}7.3 \text { Material and Methods } & 127\end{array}$

$\begin{array}{ll}7.4 \text { Results } & 129\end{array}$

$\begin{array}{ll}7.5 \text { Discussion } & 133\end{array}$

$\begin{array}{ll}7.6 \text { Conclusions } & 138\end{array}$

$\begin{array}{ll}\text { References } & 139\end{array}$

Chapter 8: Synthesis of the main research outcomes and conclusions

$\begin{array}{ll}8.1 \text { Vegetation history } & 148\end{array}$

8.2 Postglacial history of Nothofagus obliqua-type 152

8.3 Influence of ash deposition on the vegetation 156

$\begin{array}{ll}8.4 \text { Fire history } & 157\end{array}$

$\begin{array}{ll}8.5 \text { Conclusions } & 160\end{array}$

$\begin{array}{ll}\text { References } & 161\end{array}$

$\begin{array}{ll}\text { Acknowledgements } & 163\end{array}$

Declaration of Integrity 164

$\begin{array}{ll}\text { Appendices } & 165\end{array}$

Appendix 1: Table of identified pollen, spores and NPP taxa

Appendix 2: Identified pollen types pictures

Appendix 3: Full pollen diagram of Lake Avutarda, Bruja, and Vizcacha 


\section{Summary}

Northern Patagonia in Argentina $\left(40^{\circ} \mathrm{S}\right)$ offers a great opportunity to analyse the influence of volcanic ash deposition and fire on the vegetation composition. Here, three lakes located strategically along the forest-steppe ecotone within the Lanín National Park (LNP) were analysed with the aim to reconstruct past vegetation and fire history. Additionally, given the presence of tephra layers, it was possible to assess the impact of ash deposition on the vegetation composition. The results indicate that ash deposition did not trigger significant changes on the local vegetation nearby Lake Bruja (3600 cal. yr BP), Avutarda (2700 cal. yr BP), and Vizcacha (11700 cal. yr BP). However, it was observed a slight decrease in the percentage of Poaceae pollen. Overall, the results obtained from Lake Vizcacha suggest that during the Early Holocene, the vegetation nearby the Lácar basin was characterized by an open Nothofagus forest with a diverse shrub and herbaceous stratum associated to warm and dry climatic conditions. The Mid-Holocene featured a closed Nothofagus forest concomitant with more humid climatic conditions, and the presence of a small population of Austrocedrus chilensis. Finally, the Late Holocene on the three records indicates stable forest conditions, associated with the establishment of the modern rain winter/summer drought climatic regime in the region. Past fire regimes were reconstructed applying the analysis of macro charcoal particles ( $\geq 125 \mu \mathrm{m}$ ) in the cores Bruja and Vizcacha. For the Early Holocene, the results suggest moderate local fires, likely due to the dry and warm climatic conditions inferred for this period. The Mid-Holocene was characterized by a shift from low-moderate fires to fires of high magnitude. Long fire return intervals (FRI) resulted in the accumulation of biomass that given the proper climatic and ignition conditions, resulted in the severe fires detected for the Mid-Holocene. The Late Holocene featured low severity fires in both records, however, the last 2000 years show differences in the fire activity documented on Bruja and Vizcacha, probably attributed to vegetational dissimilarities. The redundancy analysis indicated a nonsignificant effect of fire on the local vegetation composition documented in Bruja. Nevertheless, this analysis showed a positive correlation between FRI and Austrocedrus chilensis, suggesting the persistence of this conifer during long periods without fires. The anthropogenic signal was detected in the last 200 years but their impact on the vegetation was almost negligible, except for the decline in Nothofagus obliqua-type, associated with the timber activities developed during the 1800 s. Moreover, the establishment of the modern climate during the last 3000 years may be responsible for the expansion of the Nothofagus obliqua-type forest within the Lácar basin, being one of the main findings of this work. 


\section{List of Tables}

Table 1. Radiocarbon ages for the cores Avutarda and Bruja based on bulk sediment. Control points based on first pollen appearance: CPa marks the establishment of Pinus plantations. CPb arrival of first European settlers indicated by Rumex acetosella.

Table 2. Sediment description of cores Avutarda and Bruja.

Table 3. Vegetation history of Avutarda and Bruja records.

Table 4. Rare pollen types (up to 3 pollen grains per sample) at Lakes Avutarda and Bruja (not shown in the pollen diagrams).

Table 5. RDA results performed on pollen percentages of Lakes Avutarda and Bruja.

Table 6. Chronological control points.

Table 7. Sediment description. Depths are given relative to the water level of the lake.

Table 8. Vegetation history of Vizcacha record.

Table 9. Simple effect derived from the RDA.

Table 10. Schematic representation by arrows of the decrease/increase in the percentage of selected taxa relative to the prior sample after a tephra deposition. Tephra thickness is shown in centimetres. Equal sign indicates no change in percentage.

Table 11. List of the records available with the presence of Nothofagus obliqua pollen type.

\section{List of Figures}

Figure 1. (a) Map with the location of the Province Neuquén in Argentina. (b) Province Neuquén and the Lanín National Park highlighted in green. (c) Close-up of the Lanín National Park with its lakes. (d) Topographic map and isohyets indicating the annual precipitation in the region taken from Lamy et al. (2010); yellow rectangle shows the location of the Lanín National Park.

Figure 2. Schematic representation of the orographic effect in the Andes Chile-Argentina.

Figure 3. Transect of annual precipitation across the Andes at $40^{\circ}-42^{\circ} \mathrm{S}$ from Viale et al. (2019).

Figure 4. Different landscapes in northern Patagonia: a) Nothofagus forest in Neuquén; b) outlook from Mario "Moro" Paschetta viewpoint in the LNP; c) slope with isolated individuals of Austrocedrus chilensis within the steppe.

Figure 5. Schematic distribution of Nothofagus alpina in Chile and Argentina based on Donoso (2013) and Sabatier et al. (2011) respectively. Notice that the grey shaded is just representing the distribution and it is not a representation of the populations size. The blue line indicates the limit of the country. 
Figure 6. Distribution of Nothofagus obliqua in Chile and Argentina (in green) modified from Azpilicueta et al. (2016). Blue areas represent lakes and rivers.

Figure 7. Map with the location of some of the records discussed in this chapter.

Figure 8. Map of the southern border between Chile and Argentina and the location of volcanos along the Andes Cordillera from Fontijn et al. (2014).

Figure 9. Consequences of the Chaitén eruption taken from Swanson et al. (2013) (Photo by J. Jones, January 2010).

Figure 10. a) Fire in a slope with $A$. chilensis close to San Martín de los Andes city (NeuquénArgentina) taken from Canal 5 Noticias (February $7^{\text {th }}, 2018$ ); b) Fire in the steppe nearby San Martín de los Andes, taken from Info Los Andes (2019).

Figure 11. Schematic representation of the multiproxy approach used in this thesis. a) Schematic representation of the phenomena captured in small lakes (fires, local vegetation, human impact). b) Multiproxy approach conducted in the present work and the possible reconstructions.

Figure 12. Schematic representation of the procedure in a palaeoecological study. Extracted from Birks and Birks (2011).

Figure 13. Location of the study sites: (a) Lake Avutarda and (b) Lake Bruja photographs; (c) position of the study sites (red stars), and the actual modern distribution of Nothofagus alpina, Nothofagus obliqua and Austrocedrus chilensis on the Argentinean side around Lake Lácar basin based on Sabatier et al. (2011); Administración de Parques Nacionales (2012); and Dezzotti and Sancholuz (1991). Notice that the studied lakes are small (Avutarda 0.75 and Bruja 1.6 hectares), and therefore not distinguishable on the map.

Figure 14. Lithology and age-depth model of (a) Avutarda, and (b) lithology, macrocharcoal (particles $/ \mathrm{cm}^{2}$ ), and age-depth model of Bruja. Notice adjusted depth in $\mathrm{Y}$ axis in age-depth model.

Figure 15. Percentage pollen diagram from (a) Avutarda record and percentage pollen diagram and macrocharcoal results from (b) Bruja, including pollen sums. Outline curve represent 10x exaggeration for minor taxa.

Figure 16. Species/sample scores of the PCA of pollen percentage data of (a) Lake Avutarda and (b) Lake Bruja. Grouping by CONISS shown by different symbols in the PCA: rhombus= zone 1; squares= zone 2; and circles= zone 3. (c) Combined ordination of Lake Bruja (squares) and Lake Avutarda (circles).

Figure 17. Redundancy analysis (RDA) biplot of selected species and samples, and explanatory variables for (a, b) Lake Bruja and (c, d) Lake Avutarda.

Figure 18. a) Map with the location of the study site referred in this study (red star), and the current distribution of Nothofagus alpina, Nothofagus obliqua, and Austrocedus chilensis around Lake Lácar basin based on Sabatier et al. (2011); Dezotti and Sancholuz (1991); Administración de Parques 
Nacionales (2012). b) topography around Lake Vizcacha taken from @Google Earth. c) photography of Lake Vizcacha taken during fieldwork.

Figure 19. Age-depth model of Vizcacha record. Blue points represent 6 calibrated ages on bulk sediment while green points represent control points. Grey area represents $0.95 \%$ confidence interval.

Figure 20. Lithology and loss on ignition results of Vizcacha core. Notice that loss on ignitions was conducted only on peat and gyttja sections excluding sediment dominated by tephra. Y axis indicates original depths.

Figure 21. Percentage pollen, spores, and NPP's diagram showing selected taxa from Vizcacha record. A 10X exaggeration (grey pattern) was used to highlight less frequent taxa. Micro charcoal particles are expressed as percentage based on terrestrial pollen sum. Notice that the lithology shown here is just representing the main changes in sediment composition excluding tephras.

Figure 22. PCA scatterplot of samples and selected taxa of Lake Vizcacha. Grouping by CONISS shown by different symbols in the PCA.

Figure 23. Summary diagram with the main result obtained from Vizcacha record. See upper label for details. Peat sections are highlighted in green.

Figure 24. Redundancy analysis (RDA) biplot of samples/species/environmental variables of Lake Vizcacha. The shows the 15 best fitting species indicated by the ordination analysis. Notice only the most significant variables according to the analysis are shown in the RDA.

Figure 25. Pollen concentration diagram of selected taxa. On the left side of the diagram, tephra layers identified on Vizcacha core are represented as bars. Grey lines represent the location of the tephra.

Figure 26. Holocene fire characteristic reconstructed from Vizcacha core. Charcoal accumulation rates (CHAR), fire episodes, fire magnitude, fire frequency, and fire return interval and their units are indicated. Zones were defined based on palynological zones.

Figure 27. Images taken under the stereomicroscope of the particles that composed the tephra layers described in Table 7 between $716-813 \mathrm{~cm}$ (10200-10700 cal. yr BP). See figure 20. Notice the pumice pebbles shown at the right.

Figure 28. Fire record and pollen concentration of selected taxa from Lake Vizcacha.

Figure 29. Map of the study area. At the right, the list of sites is displayed latitudinally $\left(34^{\circ}\right.$ to $\left.51^{\circ} \mathrm{S}\right)$.

Figure 30. Distribution of Nothofagus obliqua in Chile and Argentina (green areas), adapted from Azpilicueta et al. (2016). Blue areas represent lakes.

Figure 31. Schematic representation of the distribution of Nothofagus alpina in Chile and Argentina based on Donoso, 2013. Notice that the grey area only represents the location of the population and not the size. 
Figure 32. Maps with the changes in the percentage of $N$. obliqua-type since the LGM to the last 200 years in the sites located at the north of the study area. Percentages are represented as coloured circles. See the label at the right-bottom for the period.

Figure 33. Maps with the changes in the percentage of $N$. obliqua-type since the LGM to the last 200 years, indicated as coloured circles on the map, of the sites located in the south of the study area. See the label at the right-bottom for the period. The sites named on each map correspond to those that report the presence of the pollen type in the specified time period. Continue next page.

Figure 33. Continuation.

Figure 34. Summary diagram with the main records from mid-latitudes southern South America discussed in this work.

Figure 35. Map with the location of the study sites respect to the Lácar basin. Different colours represent the modern distribution of the species indicated in the legend, based on Administración de Parques Nacionales (2012); Sabatier et al. (2011) and Dezzotti and Sancholuz (1991).

Figure 36. Species/samples scores of the PCA of pollen percentage data of Avutarda, Bruja, and Vizcacha.

Figure 37. Comparison of the percentage of Nothofagus obliqua-type on Lake Avutarda, Bruja, and Vizcacha.

Figure 38. Map with the location of the sites analysed with the presence of Nothofagus obliquatype.

Figure 39. Matrix plot with the changes in the percentage of Nothofagus obliqua-type through time in grey scale. The sites are arranged from north (top) to south (bottom).

Figure 40. Summary of the main fire components documented in Bruja and Vizcacha core for the last 3600 cal. yr BP. 


\section{Preface}

North Patagonia Argentina $\left(40^{\circ} \mathrm{S}, 71^{\circ} \mathrm{W}\right)$ is a region that offers the opportunity to asses the impact on the vegetation of some of the main disturbance agents in the world: fire and volcanism. Since this region also comprises the forest-steppe transition, the influence of anthropogenic forces on the ecosystem and landscape process can be evaluated (Kitzberger, 2012; Risser, 1993). Here, covering a narrow band of forest at the eastern Andean slopes is located the Lanín National Park (LNP), which encompasses the main population of Nothofagus obliqua and Nothofagus alpina in Argentina (Sabatier et al., 2011). Both species have been largely studied for silvicultural strategies. Nevertheless, little is known about their past dynamic in this region.

The main objective of the present work is to reconstruct the past vegetation history near the Lácar basin and to analyse the possible influence of volcanism and fire on the vegetation at long-term scale. In order to achieve this purpose, I present the results obtained from three lake sediment cores collected in the southernmost limit of the Lanín National Park in the Province Neuquén. The overall aims are 1) to describe the changes in vegetation composition during the Holocene near the foreststeppe ecotone in northern Patagonia, 2) to analyse the variation of the populations of Nothofagus alpina and Nothofagus obliqua through the Holocene, and 3) to assess the influence of fire, volcanic ash deposition, and human impact, on the vegetation composition.

This monography is structured as follows:

Chapter 1 gives an introduction to the region of northern Patagonia, Argentina with regard to its climate and vegetation, especially of the Lanín National Park area. Additionally, special attention is given to both Nothofagus obliqua and Nothofagus alpina analysing their ecology and current investigations in Chapter 2. Chapter 3 discusses the influence of natural disturbance processes on the vegetation composition with a focus on volcanic ash deposition and fire. Chapter 4 describes briefly the palaeoecological and palynological approach.

The analyses carried out on the three sediment cores are presented in two different chapters: Chapter 5 shows the results and discusses the findings regarding ash deposition, fire and the Late Holocene vegetation history of Nothofagus obliqua and Nothofagus alpina from Lake Bruja and Lake Avutarda, whereas Chapter 6 presents the results from Lake Vizcacha with emphasis on the vegetation changes during the last 11000 years and the influence of ash deposition and fire regimes. The Holocene vegetation history of Nothofagus alpina and Nothofagus obliqua is discussed as well. 
Chapter 7 is a review of palynological records available in public data repositories as well as in the literature regarding the presence of Nothofagus obliqua pollen type. Finally, Chapter 8 synthesizes the main research outcomes and conclusions of this work. Full pollen diagrams and photographs of the pollen and non-pollen palynomorphs found during this research can be observed in the Appendices.

\section{References}

Kitzberger T (2012) Ecotones as Complex Arenas of Disturbance, Climate, and Human Impacts: The Trans-Andean Forest-Steppe Ecotone of Northern Patagonia. In: Ecotones between Forest and Grassland. R.W. Myster (ed.) New York. Springer Science+Bussiness Media, pp 59-88. DOI 10.1007/978-1-4614-3797-0_3.

Risser PG (1993) Ecotones. Ecological Applications 3:367-368.

Sabatier Y, Azpilicueta M.A, Marchelli P et al. (2011) Distribución natural de Nothofagus alpina y Nothofagus obliqua (nothofagaceae) en Argentina, dos especies de primera importancia forestal de los bosques templados norpatagónicos. Boletín de la Sociedad Argentina de Botánica 46 (1-2):131138. 


\section{Chapter 1: Introduction}

\subsection{The Lanín National Park}

The LNP is located south of the Province Neuquén, along the eastern slopes of the Andes Cordillera (Figure 1a, b, and c). Its northern limit is approximately at Lake Ñorquinco (39 $10^{\circ} \mathrm{S}$ ) while the southern limit is at $40^{\circ} 40^{\prime} \mathrm{S}$ close to the Lake Filo Hua Hum. The Park got its name from the Lanín volcano ( $39^{\circ} 38^{\prime} \mathrm{S}$; summit $3418 \mathrm{~m}$ ) whose last known eruption was at $560 \mathrm{CE}$ (Global Volcanism Program, Smithsonian Institution. Web page visited in 2019). In 1937 the area was declared a natural protected area and in 1945 it was declared as National Park (Administración de Parques Nacionales, 2012).
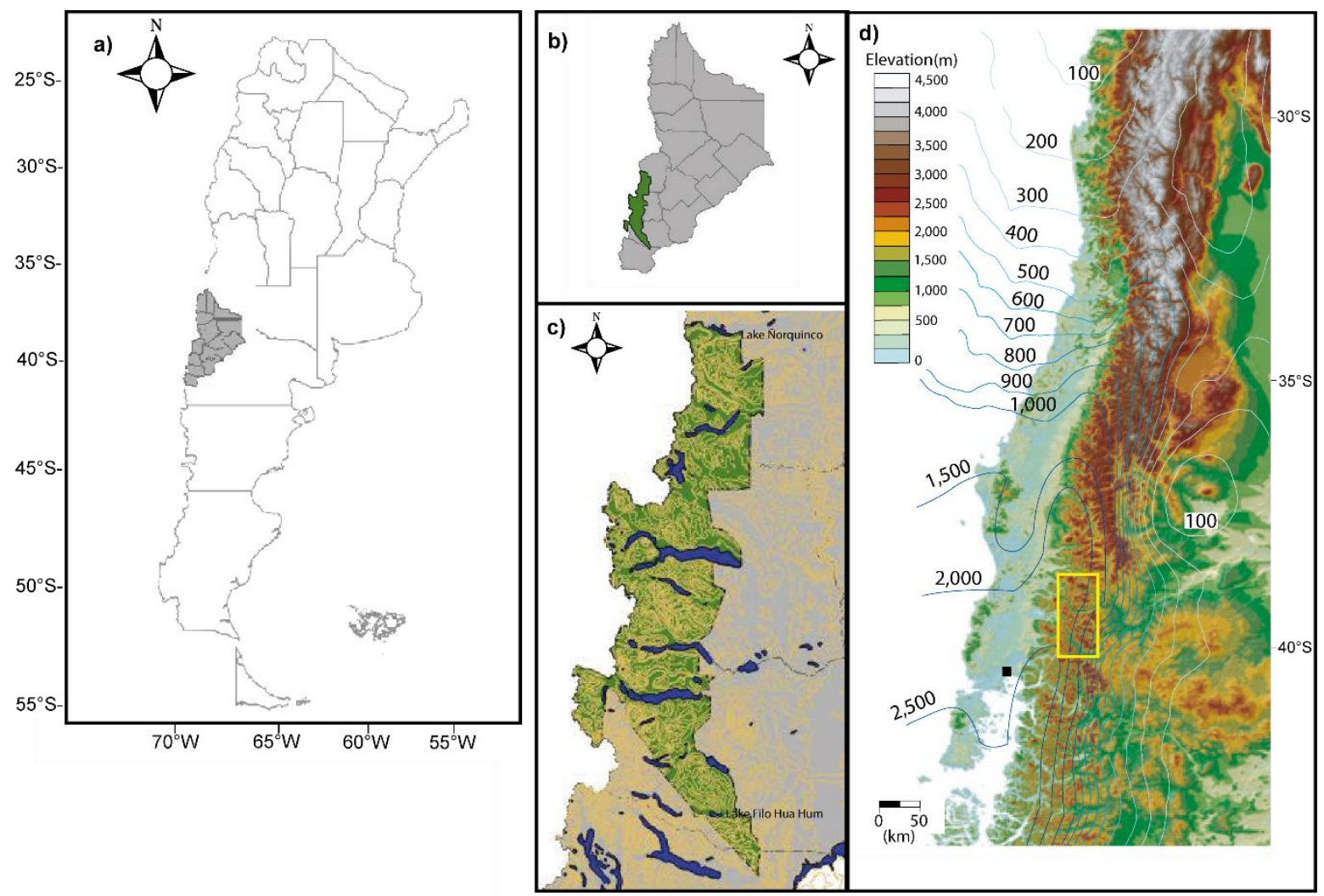

Figure 1. (a) Map with the location of the Province Neuquén in Argentina. (b) Province Neuquén and the Lanín National Park highlighted in green. (c) Close-up of the Lanín National Park with its lakes. (d) Topographic map and isohyets indicating the annual precipitation in the region taken from Lamy et al. (2010); yellow rectangle shows the location of the Lanín National Park.

The LNP is located on ancient volcanic rocks, mainly characterized by basaltic plateau and given its proximity to the Andes Cordillera, pebble fans occur as a consequence of the tectonic uplift (Iriondo, 1989). The topography in this region was affected by the advance and retreat of ice-sheet caps that 
covered broad areas in Patagonia during the Last Glacial Maximum (hereinafter LGM; Hulton et al., 2002). The presence of moraines, cirques, glacial lineation, and other glacial geomorphology features account for the influence of the ice cover on the landscape (Glasser et al., 2008; Coronato et al., 2004). The lakes located in the Park have a glacial origin as well with an elongated-shape oriented west-east (Figure 1c, Diaz et al., 2000; Iriondo, 1989). Some of these lakes are surrounded by hills with dense Nothofagus forest and are located at high elevation ( $>800 \mathrm{~m}$ a.s.l.) except for the Lake Lácar (640 $\mathrm{m}$ a.s.I.).

\subsection{Climate}

The climate in Patagonia is largely influenced by the presence of the Andes Cordillera which acts as a wall for the tropospheric flow (Garreaud et al., 2008). This mountain intercepts the equatorial belt of low pressure, the subtropical area of high pressure and the extratropical westerlies (Garreaud, 2009). Variation in the latitudinal position and intensity of the westerly winds of the southern hemisphere have been proposed as drivers of the changes on the deep-ocean circulation and atmospheric $\mathrm{CO}_{2}$ (Rojas et al., 2009). The orographic effect produced by the Andes Cordillera is responsible for the sharp precipitation gradient in Patagonia (Viale et al., 2019).

Humid air masses formed in the Pacific Ocean are transported by westerly winds towards the Andes Cordillera which is located perpendicular to the horizontal direction of these wind system (Viale and Nuñez 2011; Figure 2). The presence of this natural barrier forces an uplift of these air masses, enhances condensation, the formation of clouds, and triggers precipitation on the windward slope (Garreaud et al., 2013).

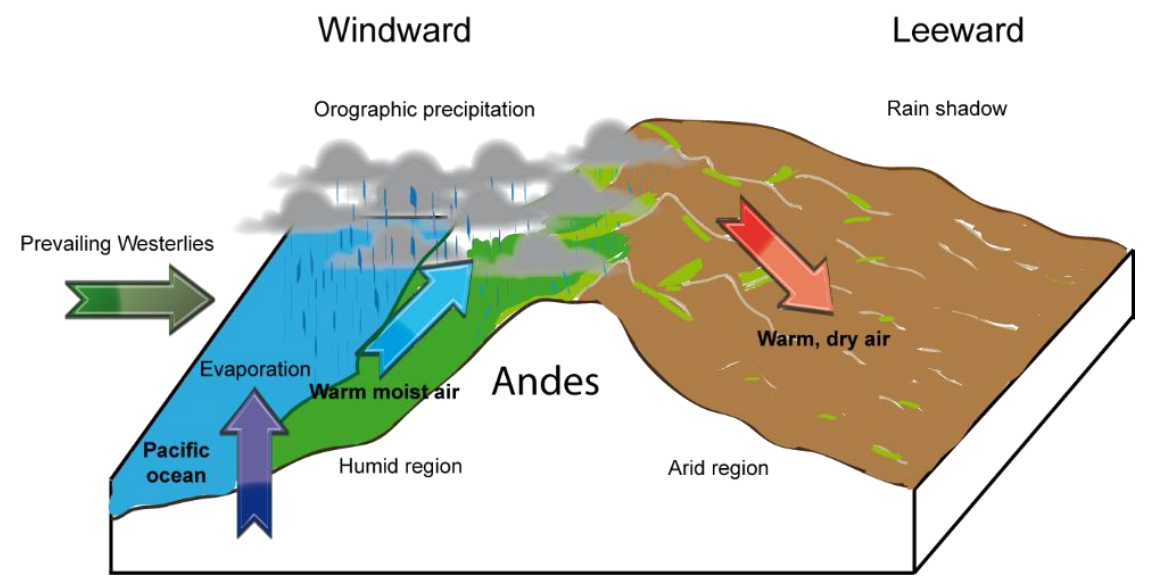

Figure 2. Schematic representation of the orographic effect in the Andes Chile-Argentina 
The origin of orographic clouds is explained by an adiabatic process on the unsaturated air parcel embedded in the flow (Barros and Lettenmaier, 2004) which turns into cold air with the altitude. Once it is above the cloud level the air parcel becomes saturated and promotes condensation, and therefore precipitation. The air parcel moves downward (east) and becomes warm adiabatically, leading to evaporation and less precipitation on leeward slopes (i.e. rain shadow effect; Barros and Lettenmaier 2004; Viale, 2010; see Figure 2). According to Viale et al. (2019), the differences in mean annual precipitation between windward (west) and leeward (east) slope of the Andes Cordillera at $40^{\circ}-42^{\circ} \mathrm{S}$ are $\sim 2400 \mathrm{~mm}$ and $<600 \mathrm{~mm}$ respectively (Figure 3 ).

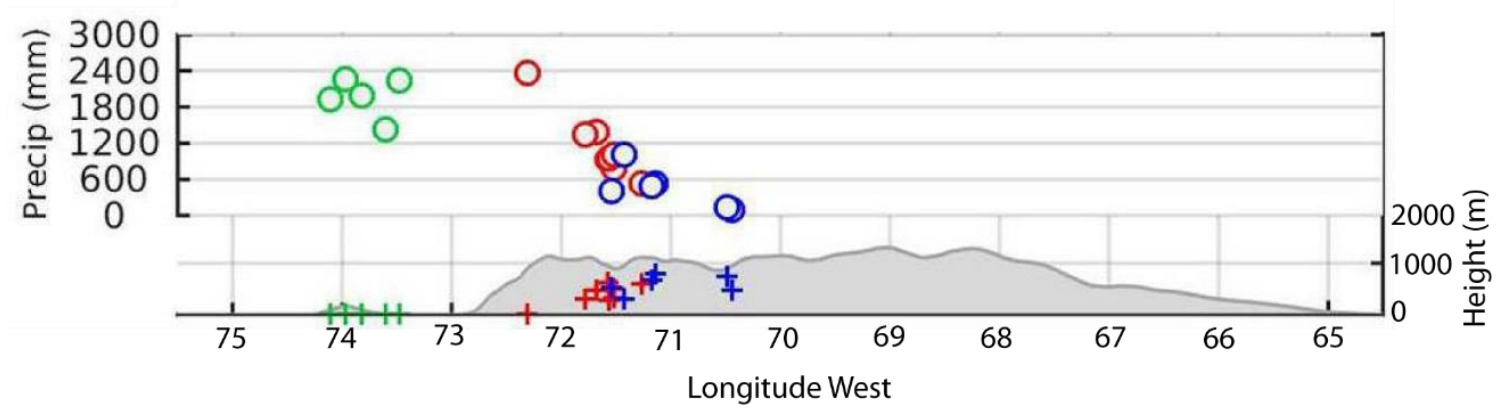

Figure 3. Transect of annual precipitation across the Andes at $40^{\circ}-42^{\circ} \mathrm{S}$ from Viale et al. (2019).

One important aspect that influences the climate in southern South America is El Niño/Southern Oscillation (ENSO) phenomenon, being a key factor in the climate variability in the region. The ENSO is the result of the interaction between the ocean and the atmosphere that occurs across its core region in the tropical-subtropical Pacific to Indian Ocean basin (Allan, 2000). This irregular phenomenon (2-7 years periodicity; Garreaud, 2009) has two different phases: El Niño and La Niña. Garreaud (2009) states the following patterns associated with El Niño episodes: 1) below average rainfall over tropical South America, 2) above average precipitation over subtropical South America, and 3) warmer than normal air temperature at tropical and subtropical latitudes. During La Niña episodes, inverse conditions predominate. Analysing the influence of El Niño events on the variability of Andean river flows, Compagnucci and Araneo (2007) established that the streamflow of Northern Patagonia rivers has a direct relationship with the sea surface temperature anomalies related to El Niño events. In addition, interannual variability on Argentinean rivers related to ENSO episodes indicates streamflow below normal during La Niña (cold phase) and normal or above average streamflow during El Niño (warm phase).

Regarding the climate of the LNP, Administración de Parques Nacionales (2012) established that the climate in general is temperate-humid with major precipitation during the winter season (May- 
August). Mean annual precipitation fluctuates between 3000 and $700 \mathrm{~mm}$ and the average temperature during winter is $4.1^{\circ} \mathrm{C}$ and $20^{\circ} \mathrm{C}$ during summer.

\subsection{The three dominant vegetation of Northwestern Patagonia}

Primarily, the drastic change in precipitation drives the current vegetation in the region. Dense forest occurs in areas with high precipitation (1500-2500 mm). Shrublands or intermediate areas occur with average precipitation between $1000-1500 \mathrm{~mm}$. Areas bordering the steppe present a precipitation regime of $600 \mathrm{~mm}$ (Kitzberger, 2012; Paruelo et al., 1998; Viale and Garreaud, 2015). This west-east variation in precipitation triggers the presence of the forest-steppe ecotone characteristics of Patagonia (Figure 4). Kitzberger (2012) provided a complete overview about the forest-steppe ecotone of northern Patagonia, highlighting the abiotic and biotic feature characteristics of this transition and describing the forest-steppe transition as a dynamic region and as a place where global change consequences will earlier become most evident. 


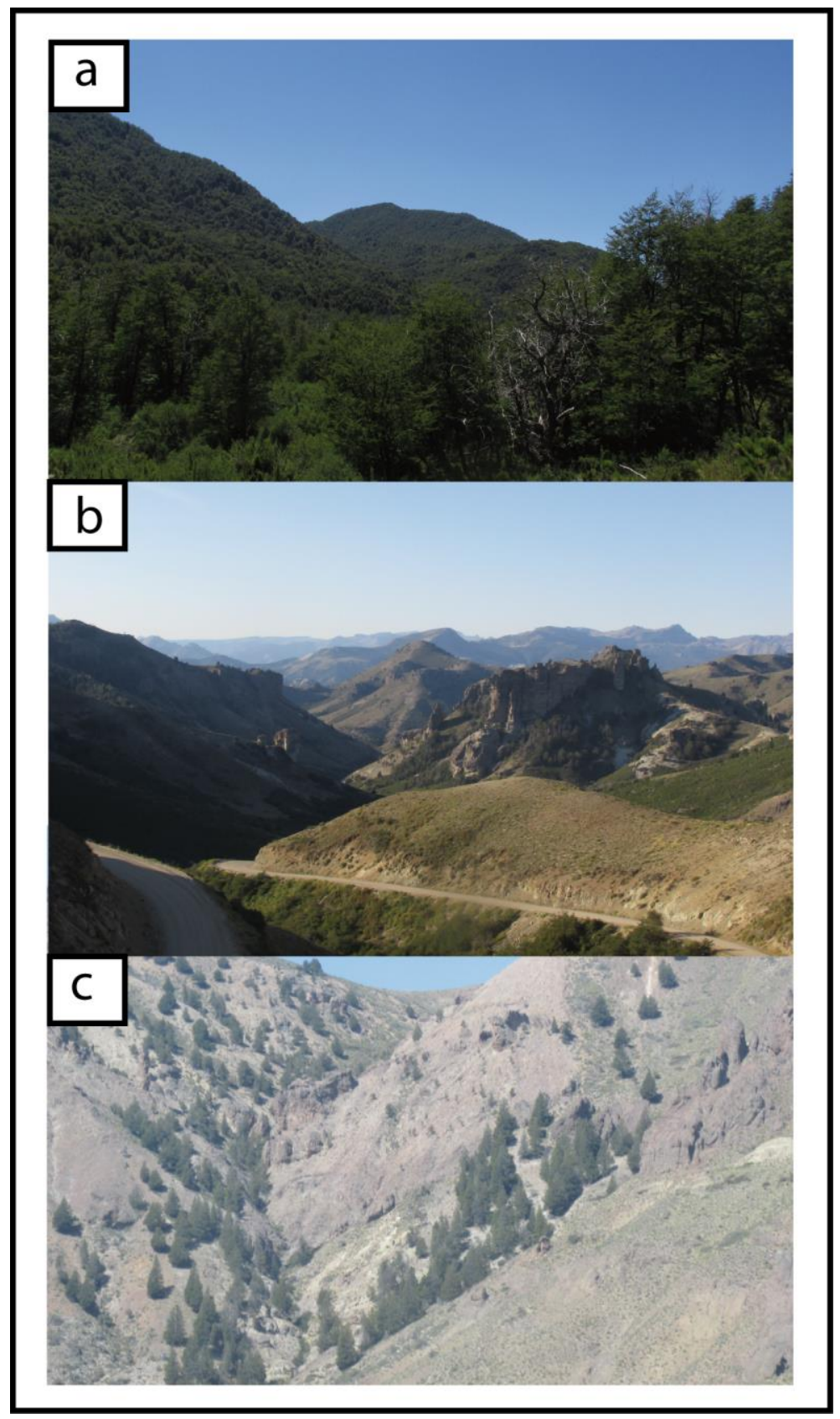

Figure 4. Different landscapes in northern Patagonia: a) Nothofagus forest in Neuquén; b) outlook from Mario "Moro" Paschetta viewpoint in the LNP; c) slope with isolated individuals of Austrocedrus chilensis within the steppe.

The changes in precipitation together with the topography determine the vegetation across westeast Andes. On the western slope of the Andes (Chilean territory, $\sim 39^{\circ} \mathrm{S}$ ), annual precipitation fluctuates between 1200 and $1600 \mathrm{~mm}$ and mean annual temperatures vary between $10^{\circ}$ and $13^{\circ} \mathrm{C}$ (Luebert and Pliscoff, 2017). Different vegetation communities can be distinguished here (from west to east, based on Luebert and Pliscoff, 2017): Deciduous Temperate Forest of Nothofagus obliqua - 
Laurelia sempervirens (0-600 m a.s.I.); Andean Temperate Deciduous Forest with Nothofagus alpina - Dasyphyllum diacanthoides (300-900 m a.s.I.); Andean Temperate Deciduous Forest with Nothofagus alpina - Nothofagus dombeyi (700-1300 m a.s.I.); Andean Temperate Deciduous Forest of Nothofagus pumilio - Araucaria araucana (600-1400 m a.s.I.); Andean Temperate Deciduous Forest of Nothofagus pumilio - Azara alpina (1400-1800 m a.s.I.); Andean Temperate Resinous Forest of Araucaria araucana - Nothofagus dombeyi (1200-1600 m a.s.I.); Andean Temperate owscrubland of Discaria chacaye - Berberis empetrifolia (1600-2300 m a.s.I.); and the Andean Temperate low-scrubland of Adesmia longipes - Senecio bipontinii (1300-2500 m a.s.l.).

On leeward slopes of the Andes (Argentinian territory), the forest is characterized by several Nothofagus species. For example, the evergreen Nothofagus dombeyi occurs between 500 and 1100 m a.s.l. whereas the deciduous Nothofagus pumilio grow between 1100-1600 m a.s.l. Nothofagus obliqua and Nothofagus alpina (deciduous trees) codominate with $N$. dombeyi (see Sabatier et al., 2011 and next chapters for more details). On bottom valleys, on rocky and xeric slopes the deciduous southern beech species Nothofagus antarctica occurs as a tall tree or as a shrub according to the environmental conditions (Donoso 2013; Veblen et al., 1996). The Nothofagus forest may also occur with some conifers like Araucaria araucana, Austrocedrus chilensis, and Fitzroya cupressoides (Donoso 2013; Veblen et al., 1995). The understory is dominated mainly by the bamboo Chusquea culeou (Pearson et al., 1994).

As the precipitation decreases towards the east, Austrocedrus chilensis and Nothofagus antarctica become dominant. Maytenus boaria, Lomatia hirsuta, Schinus patagonicus, Embothrium coccineum, and other species are part of this landscape. At the boundary with the steppe, isolated individuals of Austrocedrus chilensis occur (Villalba and Veblen, 1997). Within the steppe, bunchgrasses of Stipa speciosa, Festuca pallescens, and cushion shrubs of Mulinum spinosum occur.

\subsection{The vegetation in the Lanín National Park}

According to Administración de Parques Nacionales (2012), the vegetation in the LNP is subdivided into two phytogeographic provinces: Altoandina (High Andean) and Subantárctica (Subantarctic). The High Andean and the Subantarctic province are phytogeographic regions defined by Cabrera (1971), who stated that the High Andean Province in Neuquén corresponds to those sites above $1600 \mathrm{~m}$ a.s.I. characterized by species belonging to the genus Poa, Festuca, Deyeuxia, Deschampsia, and Cortaderia. The author separated the Subantarctic region into four different districts: 1) Araucaria araucana; 2) Deciduous forest; 3) Valdivian and 4) Magellanic. Among these, the first 
three districts with its corresponding vegetation assemblages are present in the LNP. In the next paragraphs, I will briefly mention the features of each district.

The Araucaria araucana district is located from $37^{\circ} 51^{\prime} \mathrm{S}$ to $40^{\circ} 01^{\prime} \mathrm{S}$ (northern limit of LNP is $39^{\circ} 08^{\prime} \mathrm{S}$ ). Here, Araucaria araucana occurs between 900-1800 m a.s.l. and is codominant with Nothofagus pumilio at high elevations. The shrub layer is characterized by Chusquea culeou, Berberis microphylla, Gaultheria mucronata, Maytenus disticha, Ribes magellanicum, Escallonia virgata, Nardophyllum, among others. The herbaceous stratum is composed by Lathyrus magellanicus, Adenocaulon chilense, Acaena pinnatifida, Cortaderia and Chloraea alpina.

The Deciduous district, as its name indicates, is composed of deciduous species such as Nothofagus pumilio and Nothofagus antarctica. The conifer Austrocedrus chilensis appears as an important component in this region, especially at north and east aspects (driest sites). Nothofagus antarctica occurs at low and humid sites, while Nothofagus pumilio forms the treeline ( $1800 \mathrm{~m}$ elevation). However, under extreme environmental conditions (e.g. low temperatures, strong winds) both $N$. antarctica and N. pumilio adopt a "krummholz" structure (Donoso, 2013; Veblen et al., 1996). Other species present in this district are Lomatia hirsuta, Schinus patagonicus, Maytenus boaria, Azara microphylla, Aristotelia chilensis, Fabiana imbricata, Gaultheria mucronata, Berberis darwinii and Berberis microphylla. Additionally, this district comprises of two important deciduous trees: Nothofagus alpina and Nothofagus obliqua, whose ecology will be discussed in Chapter 2.

Finally, the Valdivian district is a restricted area in Argentina, located at the border to Chile in the Provinces of Neuquén, Rio Negro and Chubut. The precipitation in this zone is abundant (> 2000 $\mathrm{mm})$, a characteristic that makes the development of Nothofagus dombeyi forest possible. This species is also present in the LNP on slopes with western aspect and around rivers. Other species present in this district are Eucryphia cordifolia, Gevuina avellana, Persea lingue, Weinmannia trichosperma, Rhaphithamnus, Drimys winteri, Embothrium coccineum, Chusquea sp and Misodendrum sp.

A floristic census done by Conticello et al. (1996) close to Lake Lácar basin indicated that Nothofagus dombeyi, Nothofagus antarctica, Nothofagus obliqua and Nothofagus alpina are the most important arboreal components around this basin. The understory is primarily composed of Chusquea culeou, Maytenus chubutensis, Berberis darwinii, Embothrium coccineum, Lomatia hirsuta, Ribes magellanicum and Gaultheria poeppigii. Among herbs Osmorhiza chilensis, Holcus lanatus, Acaena ovalifolia, Alstroemeria aurea and Blechnum dominate. 


\section{References}

Administración de Parques Nacionales (2012) Plan de Gestión Parque Nacional Lanín. Tomo I Caracterización y Diagnóstico.

Allan RJ (2000) ENSO and climatic variability in the past 150 years. In: El Niño and the Southern Oscillation. Multiscale variability and global and regional impacts. Díaz HF and Markgraf V (eds.) Cambridge University Press. pp 3-55.

Barros AP, Lettenmaier DP (1994) Dynamic modelling of orographically induced precipitation. Reviews of Geophysics 32(3):265-284.

Cabrera AL (1971) Fitogeografia de la República Argentina. Boletín de la Sociedad Argentina de Botánica 14(1-2):1-42.

Cavallotto JL, Violante RA, Hernández-Molina FJ (2011) Geological aspects and evolution of the Patagonian continental margin. Biological Journal of the Linnean Society 103:346-362.

Compagnucci RH, Araneo DC (2007) Alcances de El Niño como predictor del caudal de los ríos andinos argentinos. Ingenieria Hidráulica en México vol. 22, n 3, pp. 23-35, julio-septiembre de 2007.

Coronato A, Martínez O, Rabassa J (2004) Glaciations in Argentine Patagonia, southern South America. Quaternary Glaciations-Extent and Chronology, Part III. Ehlers J and Gibbard PL (ed).

Diaz M, Pedrozo F, Baccala N (2000) Summer classification of Southern Hemisphere temperate lakes (Patagonia, Argentina). Research and Management 5:213-229.

Donoso C (2013) Las especies arbóreas de los bosques templados de Chile y Argentina. Autoecología. Valdivia, Chile.

Glasser NF, Jansson KN, Harrison S, Kleman J (2008) The Glacial geomorphology and Pleistocene history of South America between $38^{\circ} \mathrm{S}$ and $56^{\circ} \mathrm{S}$. Quaternary Science Reviews 27:365-390.

Garreaud R, Lopez P, Minvielle M, Rojas M (2013) Large-scale control on the Patagonian climate. Journal of Climate 26:215-230.

Garreaud RD (2009) The Andes climate and weather. Advances in Geosciences 22:3-11.

Garreaud RD, Vuille M, Compagnucci R, Marengo J (2008) Present-day South American climate. Palaeogeography, Palaeoclimatology, Palaeoecology 281 (3-4):180-195.

Hulton NRJ, Purves RS, McCulloch RD, Sugden DE, Bentley MJ (2002) The Last Glacial Maximum and deglaciation in southern South America. Quaternary Science Reviews 21:233-241.

Iriondo M (1989) Quaternary lakes of Argentina. Palaeogeography, Palaeoclimatology, Palaeoecology 70:81-88. 
Kitzberger T (2012) Ecotones as Complex Arenas of Disturbance, Climate, and Human Impacts: The Trans-Andean Forest-Steppe Ecotone of Northern Patagonia. In: Ecotones between Forest and Grassland. R.W. Myster (ed.) New York. Springer Science+Bussiness Media, pp 59-88. DOI 10.1007/978-1-4614-3797-0_3.

Lamy F, Kilian R, Arz HW, Francois JP, Kaiser J, Prange M, Steinke T (2010) Holocene changes in the position and intensity of the southern westerly wind belt. Nature Geoscience 3:695-699. DOI: 10.1038/NGEO959

Luebert F, Pliscoff P (2017) Sinopsis bioclimatica y vegetacional de Chile. Editorial Universitaria.

Paruelo JM, Beltrán A, Jobbägy E, Sala OE, Golluscio RA (1998) The climate of Patagonia: general patterns and controls on biotic processes. Ecología Austral 8:85-101.

Pearson AK, Pearson OP, Gomez IA (1994) Biology of the bamboo Chusquea culeou (Poaceae: Bambusoideae) in southern Argentina. Vegetatio 111:93-126.

Rojas M, Moreno P, Kageyama M, Crucifix M, Hewitt C, Abe-Ouchi A, Ohgaito R, Brady EC, Hope P (2009) The Southern Westerlies during the last glacial maximum in PMIP2 simulations. Climate Dynamics 32:525-548.

Sabatier Y, Azpilicueta M.A, Marchelli P et al. (2011) Distribución natural de Nothofagus alpina y Nothofagus obliqua (nothofagaceae) en Argentina, dos especies de primera importancia forestal de los bosques templados norpatagónicos. Boletín de la Sociedad Argentina de Botánica 46 (1-2):131138.

Veblen TT, Donoso C, Kitzberger T, Rebertus AJ (1996) Ecology of Southern Chilean and Argentinean Nothofagus forest. In: Veblen TT, Hill, RS and Read J (eds). The ecology and Biogeography of Nothofagus Forest. Yale University Press, pp 293-353.

Veblen TT, Armesto JJ, Burns BR, Kitzberger T, Lara A, León B, Young KR (1995) The coniferous forest of South America. In: Andersson F (ed). Ecosystems of the World 6: coniferous forest. Elsevier, pp 701-725.

Viale M, Bianchi E, Cara L, Ruiz LE, Villalba R, Pitte P, Masiokas M, Rivera J, Zalazar L (2019) Contrasting climates at both sides of the Andes in Argentina and Chile. Frontiers in Environmental Science 7(69):1-15. doi: 10.3389/fenvs.2019.00069

Viale M, Garreaud R (2015) Orographic effects of the subtropical and extratropical Andes on upwind precipitation clouds. Journal of Geophysical Research: Atmospheres 120:4962-4974. doi:10.1002/2014JD023014.

Viale M, Nuñez MN (2011) Climatology of winter orographic precipitation over the subtropical central Andes and associated synoptic and regional characteristics. Journal of Hydrometeorology 12:481-507. DOI: 10.1175/2010JHM1284.1

Viale M (2010) Características de las precipitaciones orográficas de invierno sobre los Andes Subtropicales Centrales. Facultad de Ciencias Exactas y Naturales. Universidad de Buenos Aires. Ph.D. Thesis. 
Villalba R, Veblen $\Pi T$ (1997) Spatial and temporal variation in Austrocedrus growth along the foreststeppe ecotone in northern Patagonia. Canadian Journal of Forest Research 27:580-597. 


\section{Chapter 2: Ecology and current investigations on Nothofagus alpina and Nothofagus obliqua.}

\subsection{General overview of the ecology of Nothofagus alpina}

Nothofagus alpina is a deciduous southern beech species, characteristic of the Chilean and Argentinean forest. Geographically their distribution differs at both sides of the Andes Cordillera, reaching the largest latitudinal distribution gradient in Chile, and a more restricted area of distribution in Argentina (see Figure 5; Sabatier et al., 2011). This characteristic explains the pronounced clinal variation in their morphological features (Donoso et al., 2004). N. alpina is a windpollinated tree, a semi-shade tolerant species, and a monoecious tree (Riveros et al., 1995) that can grow up to 35-40 m tall and reach a diameter of even $3 \mathrm{~m}$ (Donoso, 2013). The species exhibits a rapid growth rate and due to the quality of its wood, it has been the focus of timber extraction (Marchelli and Gallo, 1999). Overexploitation and the need for timber production triggered the development of silvicultural strategies in order to promote sustainable management of this species (Echeverría and Lara, 2004).

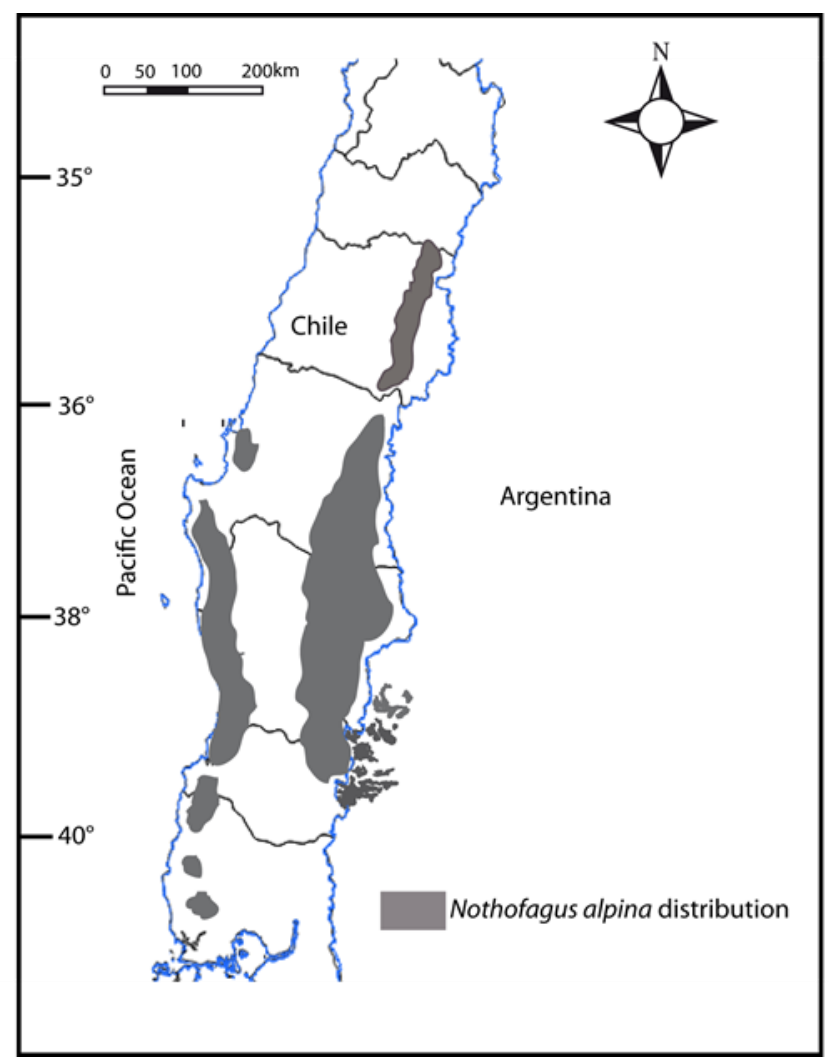

Figure 5. Schematic distribution of Nothofagus alpina in Chile and Argentina based on Donoso (2013) and Sabatier et al. (2011) respectively. Notice that the grey shaded is just representing the distribution and it is not a representation of the populations size. The blue line indicates the limit of the country. 
Given its wide latitudinal distribution (Chilean populations), N. alpina occurs in different climates, and precipitation is a key variable for the development of the species. Therefore, $N$. alpina does not develop under climate conditions characterized by severe dry summers and extreme temperatures (Donoso et al., 1993). Veblen et al. (1996) indicated that in the range of $N$. alpina in southern Chile and southwestern Argentina the precipitation varies between 1500 to $4000 \mathrm{~mm}$ and in most sites, the dry season is at least 3 months. In its northern distribution in Chile, N. alpina is located between 700 and $1000 \mathrm{~m}$ a.s.l. and occurs between 400 and $1200 \mathrm{~m}$ a.s.l. towards the south. On the other hand, in Argentina N. alpina occurs in valleys and lakes longitudinally oriented with respect to the Andes. Here, the populations are located between 800 and $1000 \mathrm{~m}$ a.s.l. Nevertheless, the species may also occur at $650 \mathrm{~m}$ a.s.l. on humid and shade slopes, i.e. south-east oriented (Donoso, 2013).

$N$. alpina can occur in association with several species according to the environmental conditions and topography. For example, N. alpina occurs together with Nothofagus obliqua, N. glauca, Aextoxicon punctatum, Persea lingue, Gevuina avellana and Jovellana punctata in the Coastal Cordillera in Chile (Donoso, 2013). Towards the south, in the Nahuelbuta Cordillera (Chile) N. alpina occurs with Laurelia sempervirens, Gevuina avellana, Persea lingue, N. obliqua, Lomatia dentata, and Aextoxicon punctatum (Donoso, 2013). Within the Andes Cordillera, at elevations $<500 \mathrm{~m}$ a.s.l. $N$. alpina is limited by $N$. obliqua and is replaced by $N$. pumilio at altitudes $>1100 \mathrm{~m}$ a.s.l. Nevertheless, in both cases these Nothofagus species can occur simultaneously (Donoso, 2013). In Argentina, N. alpina occurs together with $N$. obliqua between 600 and $800 \mathrm{~m}$ a.s.l. and with $N$. dombeyi at the highest elevations (Veblen et al., 1996).

Most of the investigation related to the ecology and dynamics of $N$. alpina are focused on its timber potential, and therefore from a silvicultural management perspective. Despite this, these works allow a better understanding of the natural regeneration of this deciduous tree. According to Weinberger and Ramirez (1999), in many areas where N. alpina populations were exploited, new individuals developed by a stump-root system (stump-resprouting). Weinberg and Ramirez (2001) also analysed the natural regeneration of $N$. obliqua, $N$. dombeyi, and $N$. alpina in south-central Chile concluding that $N$. alpina grows under low relative luminosity, reduced evaporation, and moderate temperatures. However, prolongate frost periods diminish its development. Not less important is the fact that the regeneration of several Nothofagus species depends on altitude, topography, and arboreal cover (Weinberger and Ramirez, 1999). 


\subsection{General overview of the ecology of Nothofagus obliqua}

Nothofagus obliqua, as well as N. alpina, is a deciduous tree and a wind-pollinated species. Its distribution is wider in Chile, while in Argentina it is narrower and more restricted to five lake basins and a river margin (Azpilicueta et al., 2014; Sabatier et al., 2011). Interesting is the fact that $N$. obliqua occurs in sympatry with $N$. alpina and hybridization is common between both species (Donoso et al., 1990; Marchelli and Gallo, 2004). This characteristic has been one of the many focusses in genetic studies and it will be discussed in the next paragraph.

In Chile, N. obliqua occurs between $30^{\circ} 30^{\prime}$ to $41^{\circ} \mathrm{S}$, and in Argentina the populations are divided into two different locations. One is located at $36^{\circ} 49^{\prime} \mathrm{S}, 71^{\circ} 04^{\prime} \mathrm{W}$ and $1500 \mathrm{~m}$ a.s.l. (around Lagunas de Epulauquen; Azpilicueta et al., 2014). The second population is located approximately between $39^{\circ}$ and $40^{\circ} \mathrm{S}$ around four lake basins: east of Lake Aluminé, Lake Ñorquinco, Lake Quillén, and Lake Lácar. At $39^{\circ} 30^{\prime} \mathrm{S}$ the easternmost population of $\mathrm{N}$. obliqua is located nearby Aluminé river $\left(39^{\circ} \mathrm{S}\right.$, $70^{\circ} \mathrm{W}$ ) (Sabatier et al., 2011). In the Chilean Andes, this species occurs between 1000 and $2000 \mathrm{~m}$ a.s.I. further north and close to the sea level to $500 \mathrm{~m}$ a.s.I. In the Coastal Cordillera it is present between 700 and $2000 \mathrm{~m}$ a.s.I. in its northernmost limit (Donoso, 2013). In Argentina, N. obliqua occurs between 650 and $800 \mathrm{~m}$ a.s.I. (Sabatier et al., 2011). Here, the mean annual precipitation is $2500 \mathrm{~mm}$ nearby the Andes, and $750 \mathrm{~mm}$ towards the easternmost distribution limit of the species (Sabatier et al., 2011). In Chile, N. obliqua occurs in a wide range of mean annual precipitation. However, the minimum annual precipitation, where the species can grow is $>500 \mathrm{~mm}$ (Donoso, 2013). N. obliqua is considered as one of the most thermophilous Nothofagus species, persisting long dry periods and high temperatures (Donoso, 2013). 


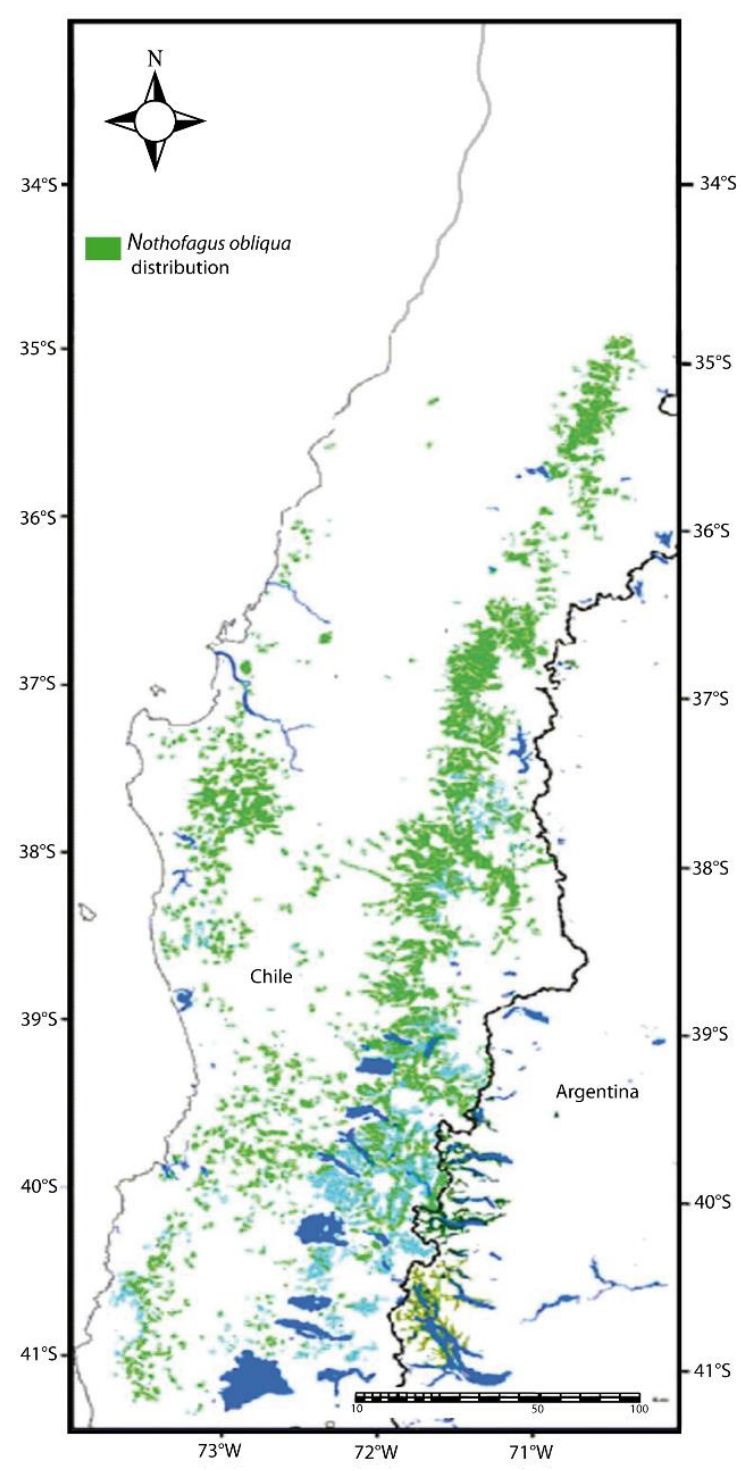

Figure 6. Distribution of Nothofagus obliqua in Chile and Argentina (in green) modified from Azpilicueta et al. (2016). Blue areas represent lakes and rivers.

In general, $N$. obliqua occurs within different vegetation communities since it has a wide latitudinal distribution, especially in Chile. Therefore, it occurs together with Maytenus boaria, Cryptocaria alba, Quillaja Saponaria and Lithraea caustica in its northern distribution (Donoso, 2013). Towards the south, N. obliqua occurs together with Persea lingue, Laurelia sempervirens, Aextoxicon punctatum, Eucryphia cordifolia and Nothofagus dombeyi (Donoso, 2013).

Regarding its dynamics, $N$. obliqua is considered as a pioneer species after soil disturbance since it is a shade-intolerant species (Salas et al., 2006; Veblen et al., 1996). Nevertheless, Salas et al. (2006) indicate that $N$. obliqua cannot regenerate under a dense canopy and little exposed bare mineral soil and is usually replaced by very-shade-tolerant species. A work developed by Dezzotti et al. (2004) focusing on the analysis of the effect of induced-forest gaps in the regeneration of $N$. alpina, 
$N$. obliqua, and $N$. dombeyi concluded that all the species analysed established simultaneously within the gaps, N. obliqua being the second species more successful after $N$. alpina. On the other hand, Weinberger and Ramirez (2001) indicated that N. obliqua can tolerate night temperatures close to the freezing point.

\subsection{Summary of the palynological records with Nothofagus alpina-Nothofagus} obliqua presence in southern South America

Despite the numerous studies regarding the ecology and silvicultural management, only few studies focus on the past vegetation history of $N$. alpina and $N$. obliqua, especially in palynological and fossil records. Moreover, open access to this data (i.e. pollen counts) is even more limited in public repositories. The scattered and fragmented population of both deciduous trees in Chile and particularly in Argentina may account for the scarce presence of the Nothofagus obliqua pollen type in palynological records from southern South America. An important feature, and somehow a disadvantage, is the fact that both $N$. alpina and $N$. obliqua exhibit a similar pollen morphology which makes them undistinguishable from each other (Markgraf et al., 2002). As a result, most of the pollen diagrams indicate them as Nothofagus obliqua-type.

One of the first palynological records that show the presence of this pollen type is the Tagua Tagua record in central Chile $\left(34^{\circ} 30^{\prime} \mathrm{S}, 71^{\circ} 10^{\prime} \mathrm{W}\right)$, established by Heusser (1983). This record expands > 45000 years (radiocarbon years) and since the beginning $N$. obliqua-type was present with an approximate percentage of $<10$. At around 14000 years ago, this pollen type decreases abruptly, and its presence is barely noticeable since then. This record basically suggests a completely different vegetation in the region, where $N$. obliqua was more abundant than nowadays. At present, the species that form the N. obliqua pollen type at this latitude (Nothofagus obliqua and N. glauca) are only present in a small population close to Tagua Tagua. In Argentina, Markgraf (1987) published a pollen record from Lagunas de Epulauquen, located within the northern limit of the subantarctic Nothofagus forest $\left(36^{\circ} 51^{\prime} \mathrm{S} ; 71^{\circ} 02^{\prime} \mathrm{W}\right)$. Here, the $N$. obliqua-type is present since the beginning of the record around 10000 radiocarbon years, with a percentage of $<4$ until around 7000 radiocarbon years. From 7000 to present, this record shows an abundance of approximately $10 \%$ with several fluctuations.

In a posterior re-evaluation of this site Markgraf et al. (2009) achieved to capture the last 17000 cal. yr BP and N. obliqua pollen type was scarcely present between 17000 and 6000 cal. yr BP. From 
$6000 \mathrm{cal}$. yr BP to present, the percentage of this pollen type increase and ranged between 5 to $10 \%$. The environmental interpretation obtained from this record suggests that the presence of $N$. obliqua and other plant taxa indicates a shift to present-day winter rain/summer drought conditions at around $5300 \mathrm{cal}$. yr BP (Markgraf et al., 2009). The records analysed by Heusser (1983), Markgraf (1987) and Markgraf et al. (2009) accounted for the past vegetation history of Nothofagus obliqua within their northernmost known distribution in Chile and in Argentina.

Located further west from Lagunas de Epulauquen (Argentina), Heusser et al. (2006a) presented a continuous record of temperate South American vegetation and climate offshore of the city of Concepcion, Chile $\left(36^{\circ} 13^{\prime} \mathrm{S} ; 73^{\circ} 40^{\prime} \mathrm{W}\right)$. This record comprises the last $140000 \mathrm{cal}$. yr BP with $N$. obliqua pollen type present since the beginning of the record. The authors show a rise in the percentage of this pollen type from around 5 to $15 \%$ during the Marine Isotope Stage 5 (MIS5). A second rise in the percentage of $N$. obliqua-type occurs in MIS1 ( 10\%) together with an increase in the percentage of Podocarpus andina and Filicinae fern. This assemblage is interpreted as a mark for the deglacial transition. This marine record indicates a rise of $N$. obliqua (Lowland Forest) after the LGM with maximum percentage values during the Holocene. The presence of $N$. obliqua pollen type was also detected in a marine sediment core collected from the Pacific Ocean at $41^{\circ} 00^{\prime} \mathrm{S} ; 74^{\circ} 26^{\prime} \mathrm{W}$. The record comprises the last $\sim 50000$ years ago. Here, an expansion of the Lowland Deciduous Beech Forest (N. obliqua) is accelerated in the Holocene (Heusser et al., 2006b). The authors infer that changes in vegetation reflect changes in temperature and precipitation.

A bit further south of the records mentioned, the Purén-Lumaco Valley record from Abarzúa et al. (2014) $\left(38^{\circ} \mathrm{S}\right)$ indicates the scarce presence of $N$. obliqua-type from the beginning of the record (26000 cal. yr BP). A rise in the abundance of N. obliqua-type occurs during the Early/Mid-Holocene (11000-4000 cal. yr BP). The authors suggest that the occurrence of $N$. obliqua-type at 11000 indicates the end of the glacial period since this taxon is a warm-temperate indicator.

Another record located in the southernmost Chilean distribution of N. obliqua and N. alpina in the Vicente Perez Rosales National Park (41ㅇ; Villagrán, 1980) accounts for the presence of $N$. obliqua pollen type since the beginning of La Cumbre record, approximately 6800 years ago (20\%). Afterward, the percentage of $N$. obliqua-type reaches its maximum value of $30 \%$ and declines gradually with the last peak of $7 \%$ at $2855 \pm 80$ years. Subsequently, $N$. obliqua-type disappears from the record. Regarding climatic interpretation suggested by the author, the Nothofagus obliqua pollen type represents warm and dry conditions. 
Recently, Moreno et al. (2018) published a palynological record from Lake Pichilaguna $\left(41^{\circ} \mathrm{S}\right)$ showing the vegetation changes during the last 25000 years in the Lake District region in Chile. This record is also located within the southernmost latitudinal limit of $N$. obliqua and $N$. alpina populations in Chile. The results indicate traces of $N$. obliqua-type during the LGM until its visual disappearance from the record between $13000-10000$ years ago. The Holocene is characterized by a slight rise in the percentage of this pollen type with its maximum percentages at $2000 \mathrm{cal}$. yr BP (Late Holocene). In this study, N. obliqua characterizes the Lowland Deciduous Southern Beech Forest present in the Longitudinal Valley in the region around $41^{\circ} \mathrm{S}$ in Chile. The authors suggest that the persistence of this pollen type during the Holocene may indicate the establishment of the Lowland Deciduous Forest north of Lake Pichilaguna while their southern limit remains stable through the Holocene.

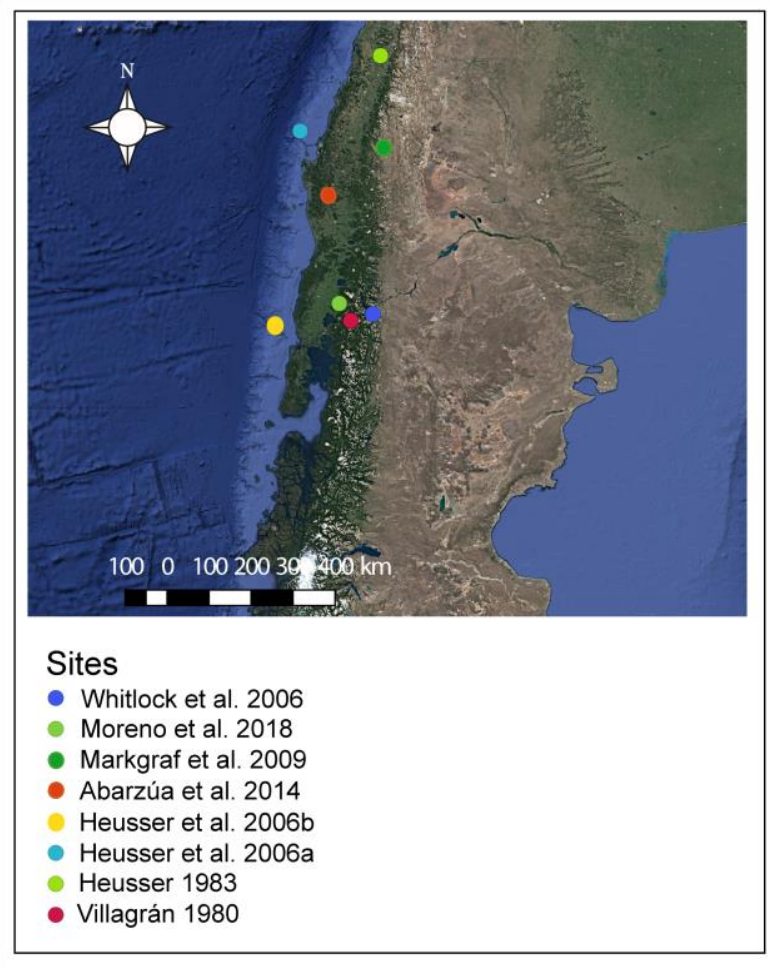

Figure 7. Map with the location of some of the records discussed in this chapter.

To summarize, some of the records discussed in this section account for the presence of $N$. obliqua pollen type even before the LGM. However, their expansion started during the Holocene in most of the records and its maximum percentages occurred during the Late Holocene. Except for La Cumbre record from Villagrán (1980), which shows a maximum percentage of this pollen type around 6000 years ago while disappearing from the record at around 2000 years ago. However, the palynological 
record by Markgraf et al. (2009) comprises the vegetation history of the last 17000 with N. obliquatype present since then. The later expansion of $N$. obliqua at 6000 years ago, is interpreted as the establishment of the current climatic conditions in the region. So far, this is the only palynological record located within a main population of Nothofagus obliqua in Argentina. Other pollen records in Argentina are located in regions where $N$. obliqua and $N$. alpina do not occur at present. For example, studies carried out close to Bariloche city $\left(41^{\circ} \mathrm{S}\right)$ do not indicate the presence of $N$. obliqua pollen type (Whitlock et al., 2006). However, it might occur that those record detected the presence of $N$. obliqua-type, but probably since this pollen type is long-distance transported, further interpretations cannot be done.

\subsection{Some examples of genetic studies on Nothofagus alpina and Nothofagus obliqua}

Nothofagus obliqua and N. alpina are two species of high economic value since both possess a good quality of timber and therefore, silvicultural management strategies are focused on the artificial and natural regeneration of these species with commercial purposes as well as restoration. Hence, domestication and genetic improvement of both species have been carried out in Argentina and Chile (Gallo et al., 2006).

One important aspect analysed for geneticists is that $N$. alpina and $N$. obliqua populations occur in sympatry in some areas of their distribution, and hybridization among these species has been detected (Donoso et al., 1990; Marchelli et al., 2004). In this respect, the use of genetic analysis provides a valuable set of information that can be used for conservation and restoration strategies and the maintenance of the genetic identity of the analysed species (Azpilicueta et al., 2016).

Genetic studies together with palynological records provide a strong support for the reconstruction of possible past migratory routes of some species after the Last Glacial Maximum (LGM), as well as the possible existence of glacial refugia in which some taxa could have survived during this period (Azpilicueta et al., 2016; Azpilicueta et al., 2009; Marchelli and Gallo, 2004). For example, in some populations of $N$. alpina in Argentina natural hybridization, unidirectional gene flow, and the possible existence of glacial refugia were assessed in order to evaluate the importance of these processes in establishing the distribution patterns of the genetic variation. The authors (Marchelli and Gallo, 2004) concluded that hybridization and glaciation shaped the distribution of the genetic variation in N. alpina. Moreover, the authors emphasized the lack of palynological records close to the areas of investigation to support the hypothesis of glacial refugia at eastern Andes' slopes. 
Azpilicueta et al. (2009) conducted chloroplast DNA analysis in N. obliqua populations in Chile and Argentina in order to determine the effect of glaciations on these populations, their similarities, and the phylogeography of this species. Their results suggest common haplotypes between the population of the longitudinal valley of Chile with Argentinean populations at approximately the same latitudinal distribution $\left(40^{\circ} \mathrm{S}\right)$. The same pattern occurs in populations of $N$. obliqua close to Lagunas de Epulauquen that share haplotypes with Chilean populations at the same latitude $\left(36^{\circ} \mathrm{S}\right)$ in the Andes Cordillera. An interesting fact is that the authors showed different haplotypes in two southern Argentinean populations of $N$. obliqua separated by hundred kilometres between $39^{\circ} \mathrm{S}$ and at $40^{\circ} \mathrm{S}$. They argued that these differences are the result of topographic barriers between both populations that triggered their genetic isolation. Therefore, pollen flux among individuals might not have occurred here.

There are many advances and contributions of genetic studies to the understanding of evolutionary patterns, adaptations, diversity and phylogeography of important taxa in southern South America (N. obliqua and N. alpina: Azpilicueta et al., 2009; Gallo et al., 2006; Austrocedrus chilensis: Pastorino and Gallo, 2001; Pastorino and Gallo, 2002; Araucaria araucana: Martin et al., 2014; Fitzroya cupressoides: Premoli et al., 2000). Nonetheless, despite the relevant information provided for these studies, palaeoecological studies can contribute, and support or discard the interpretation of migratory routes and refugia in non-glaciated areas during the LGM. For example, this is the case for the palynological record from Mallin Vaca Lauquen, close to Lagunas de Epulaquen (Markgraf et al., 2009). This record comprises the last $17000 \mathrm{cal}$. yr BP and has been used as a support for migratory routes of $N$. obliqua from the western Andes into Argentina (Azpilicueta et al., 2016).

\section{References}

Abarzúa AM, Pichincura AG, Jarpa L, Martel-Cea A, Sterken M, Vega R, Pino M (2014) Environmental responses to climatic and cultural changes over the last 26000 years in Purén-Lumaco valley $\left(38^{\circ} \mathrm{S}\right)$ in Tom D. Dillehay (ed), The Teleoscopy Polity. New York, Springer DOI:10.1007/978-3-319-031286_6

Azpilicueta MM, El Mujtar VA, Gallo LA (2016) Searching for molecular insight on hydridization in Nothofagus spp. Forest at Lagunas de Epulauquen, Argentina. Bosque 37(3): 591-601.

Azpilicueta MM, Pastorino MJ, Puntieri J, Barbero F, Martínez-Meier A, Marchelli P, Gallo LA (2014) Robles in Lagunas de Epulauquen, Argentina: previous and recent evidence of their distictive character. Revista Chilena de Historia Natural 87:24. 
Dezzotti A, Sbrancia R, Roat D, Rodríguez-Arias M, Parisi A (2004) Colonización y crecimiento de renovales de Nothofagus después de cortas selectivas de un rodal en la Patagonia, Argentina. Investigación Agraria: Sistemas y Recursos Forestales 13(2):329-337.

Donoso C (2013) Las especies arbóreas de los bosques templados de Chile y Argentina. Autoecología. Marisa Cuneo Ediciones. Valdivia, Chile.

Donoso C, A Premoli, L Gallo, R Ipinza. (2004) Variación intraespecífica en las especies arbóreas de los bosques templados de Chile y Argentina. Santiago, Chile. Editorial Universitaria. 419 p.

Donoso P, Donoso C, Sandoval V (1993) Proposición de zonas de crecimiento de renovales de roble (Nothofagus obliqua) y raulí (Nothofagus alpina) en su rango de distribución natural. Bosque 14(2): 37-55.

Donoso C, Morales J, Romero M (1990) Hibridación natural entre roble (Nothofagus obliqua) (Mirb) Oerst. y raulí ( $N$. alpina) (Poepp. \& Endl.) Oerst, en bosques del sur de Chile. Revista Chilena de Historia Natural 63:49-60.

Echeverría C, Lara A (2004) Growth patterns of secondary Nothofagus obliqua-N. alpina forests in southern Chile. Forest Ecology and Management 195:29-43.

Gallo LA, Marchelli P, Azpilicueta MM, Crego P (2006) El uso de marcadores genéticos en el género Nothofagus con especial referencia a raulí y roble. Bosque 27(1):3-15.

Heusser L, Heusser C, Mix A, Mc Manus J (2006a) Chilean and Southeast Pacific paleoclimate variations during the last glacial cycle: directly correlated pollen and $\delta^{18} \mathrm{O}$ records from ODP Site 1234. Quaternary Science Review 25:3404-3415.

Heusser L, Heusser C, Pisias Nicklas (2006b) Vegetation and climate dynamics of southern Chile during the past 50,000 years: results of ODP Site 1233 pollen analysis. Quaternary Science Reviews 25:474-485.

Heusser CJ (1983) Quaternary pollen record from Laguna de Tgaua Tagua, Chile. Science 219 (4591):1429-1432.

Marchelli P, Gallo LA (2004) The combined role of glaciation and hybridization in shaping the distribution of genetic variation in a Patagonian southern beech. Journal of Biogeography 31:451460.

Marchelli P, Gallo LA (1999) Annual and geographic variation in seed traits of Argentinean populations of southern beech Nothofagus nervosa (Phil.) Dim. et Mil. Forest Ecology and Management 121:239-250.

Markgraf V, Whitlock C, Anderson RS, García A (2009) Late Quaternary vegetation and fire history in the northernmost Nothofagus forest region: Mallín Vaca Lauquen, Neuquén Province, Argentina. Journal of Quaternary Science 24(3):248-258.

Markgraf V, Webb RS, Anderson KH, Anderson L (2002) Modern pollen/climate calibration for southern South America. Palaeogeography, Palaeoclimatology, Palaeoecology 181:375-397.

Markgraf V (1987) Paleoenvironmental changes at the northern limit of the Subantarctic Nothofagus forest, Lat $37^{\circ} \mathrm{S}$, Argentina. Quaternary Research 28:119-129. 
Martin MA, Mattioni C, Lusini I, Molina JR, Cherubini M, Drake F, Herrera MA, Villani F, Martin LM (2014) New insights into the genetic structure of Araucaria araucana forest based on molecular and historic evidences. Tree Genetic and Genomes 10(4):839-851. 10:839-851 DOI 10.1007/s11295014-0725-1

Moreno PI, Videla J, Valero-Garcés B, Alloway BV, Heusser LE (2018) A continuous record of vegetation, fire regime and climatic changes in northwestern Patagonia spanning the last 25000 years. Quaternary Science Reviews 198:15-36.

Pastorino MJ, and Gallo LA (2002) Quaternary evolutionary history of Austrocedrus chilensis, a cypress native to the Andean Patagonian forest. Journal of Biogeography 29:1167-1178.

Pastorino MJ, Gallo LA (2001) Linkage relationships as a useful tool to state interspecific gene homology: case study with isozyme loci in Austrocedrus chilensis (Cupressaceae). Silvae Genetica 50(5-6):233-239.

Premoli AC, Kitzberger T, Veblen TT (2000) Isozyme variation and recent biogeographical history of the long-lived conifer Fitzroya cupressoides. Journal of Biogeography 27:251-260.

Riveros M, Paredes MA, Rosas MT, Cardenas E, Armesto J, Arroyo MTK, Palma B (1995) Reproductive biology in species of the genus Nothofagus. Environmental and Experimental Botany 35(4):519-524.

Sabatier Y, Azpilicueta M.A, Marchelli P et al. (2011) Distribución natural de Nothofagus alpina y Nothofagus obliqua (nothofagaceae) en Argentina, dos especies de primera importancia forestal de los bosques templados norpatagónicos. Boletín de la Sociedad Argentina de Botánica 46 (1-2):131138.

Salas C, LeMay V, Núñez P, Pacheco P, Espinosa A (2006) Spatial patterns in an old-growth Nothofagus obliqua forest in south-central Chile. Forest Ecology and Management 231:38-46.

Veblen TT, Donoso C, Kitzberger T, Rebertus AJ (1996) Ecology of Southern Chilean and Argentinean Nothofagus forest. In: Veblen TT, Hill, RS and Read J (eds). The ecology and Biogeography of Nothofagus Forest. Yale University Press, pp 293-353.

Weinberger P, Ramirez C (2001) Microclima y regeneración natural de Raulí, Roble y Coigüe (Nothofagus alpina, N. obliqua y N. dombeyi). Bosque 22(1):11-26.

Weinberger P and Ramirez C (1999) Sinecología de la regeneración natural del Raulí (Nothofagus alpina). Revista Chilena de Historia Natural 72:337-351.

Villagrán C (1980) Vegetationsgeschichtliche und pflanzensoziologische Untersuchungen im Vicente Pérez Rosales Nationalpark (Chile). Dessertationes Botanicae 54. Ganter Verlag K.G. Germany.

Whitlock C, Bianchi MM, Bartlein PJ, Markgraf V, Marlon J, Walsh M, Mc Coy N (2006) Postglacial vegetation, climate, and fire history along the east side of the Andes (lat $41-42.5^{\circ} \mathrm{S}$ ), Argentina. Quaternary Research 66:187-201. 


\section{Chapter 3: Disturbance processes in northern Patagonia}

\subsection{Disturbance}

Disturbance is a wide term that has been described as an event that "causes departure from a normal or desired state, or a source of stochasticity" (Newman, 2019), or an abrupt event that can drastically change the ecosystem characteristics (Begon et al., 1996). The most accepted definition of disturbance is the one developed by White and Pickett (1985) who states as follows: "A disturbance is any relatively discrete event in time that disrupts the ecosystem, community, or population structure and changes resources, substrate availability, or the physical environment". Likewise, Rykiel (1985) indicates that disturbance is "a cause, a physical force, agent, or process, either abiotic or biotic, causing a perturbation in an ecological component or system". In all the definitions, there is an event of biotic or abiotic nature that causes a change in a system. Additionally, the causal factor of disturbance -endogenous or exogenous- operate at different sizes, frequency, magnitude, predictability and timing of impact (Attiwill, 1994).

How the ecosystem responds to any disturbance agent may depend on the state of the community prior to the disturbance (White and Pickett, 1985). The predisposition of the ecosystem to disturbance, the disturbance mechanism, and magnitude will determine the kind of impact. Moreover, some disturbance agents may increase the predisposition of the ecosystem to another disturbance. For example, a severe drought in a forest can delete some individuals, this increase fuel availability and make the forest more susceptible to fire.

Related to the effects of a certain disturbance process, the vegetation features play an important role in determining the survival or death of an individual or community. This is the case of Araucaria araucana whose thick bark makes it resistant to surface fires (González et al., 2010; Veblen et al., 1995). Another example of how the features of a given species can determine its resistance to a specific disturbance agent, is the root systems in Nothofagus dombeyi versus Austrocedrus chilensis, where the first one is shallow-rooted species that makes it more susceptible to windthrow while $A$. chilensis is relatively wind-firm (Veblen and Lorenz, 1987).

\subsection{Disturbance agents in Patagonia}

Patagonia offers a wide possibility to analyse the impact of several disturbance regimes and the behaviour of plant communities. Areas close to the Andes Cordillera are more susceptible to volcanic eruptions or ash deposition (Veblen et al., 1977), although given the strong westerly winds 
most of the ashes travel hundreds of kilometres also affecting the vegetation in steppe areas in eastern Patagonia by coverage (Gaitan et al., 2011) affecting vegetation. Dense Nothofagus forest provides the opportunity to analyse succession after the creation of forest opening produced by windthrow or another disturbance agent (Veblen et al., 1980; Gutierrez et al., 2004). The foreststeppe ecotone has been used as a natural laboratory to assess how the vegetation responds to fire and grazing (Sottile et al., 2015).

Depending on several factors (topography, elevation, climate) some disturbance agents are more important in terms of the impact they have on the vegetation. However, the scale of disturbance, either fine-scale or coarse-scale have different ecological roles in shaping the vegetation (Kitzberger, 2012). In addition, human-induced disturbance (grazing, pollution, land clearing) makes vegetation more susceptible to natural disturbance such as fire, storms, and volcanic eruptions. In the following subchapters, I will describe and synthesize the main disturbance agents in Patagonia with a special focus on the effect and role of volcanic ash deposition and fire on the vegetation composition and dynamics through some examples described in literature.

\subsection{Volcanism and vegetation responses in Patagonia}

The catastrophic consequences of volcanism have been reported and described by eyewitnesses. Darwin on his trip on board of The Beagle to the region of southern Chile, described his impressions regarding the volcanic activity: “... at the same hour when the whole country around Concepción was permanently elevated, a train of volcanoes situated in the Andes, in front of Chiloé, instantaneously spouted out a dark column of smoke, and during the subsequent year continued in uncommon activity" (Darwin, 1839).

Volcanic eruptions are a primary example of disturbance that comprise several distinct disturbances such as mudflow, debris avalanche, pyroclastic flow, blowdown, and ash deposition (Turner et al., 1997). Given a distinctive disturbance, different disturbance mechanisms occur like erosion, burial, abrasion, heating, and impact force (Swanson and Major, 2005). The damage to a certain ecosystem will depend on the type of mechanism, its impact, and magnitude. A famous example of the effect of a volcanic eruption on the ecosystem is the destructive eruption of Mount St. Helens (Washington, USA) in 1980. The largest landslide ever seen, and multiple square miles of trees toppled are just some examples of the dramatic consequences of this massive disturbance events. Among the effects of this disturbance on plant communities, blown down trees, scorched trees, and abrasion can be mentioned (Turner et al., 1997). The effects on the vegetation were related to the 
morpho-physiology of the plants, as well as with the location and topography where the communities were located with respect to the volcano. Moreover, the persistence of the vegetation after disturbance determined the biological legacies. Both "living and death species are important in the development of the posteruption ecosystems" as well as the timing of the disturbance affected biological responses at scales of time, season, and stage of succession (Crisafulli and Dale, 2018)

In Patagonia, given the presence of several active volcanoes along the Andes Cordillera (Fontijn et al., 2014) it is possible to study how disturbance by volcanic eruption contributes to the forest dynamic in this region. Veblen et al. (1977) assessed the impact of volcanism in the succession of the upper forest limit in south-central Chile. The authors conclude that catastrophic volcanism depressed the timberline to an average of 100 to $300 \mathrm{~m}$, affecting the vegetation. Nevertheless, they identified the resistance of Nothofagus antarctica to scoria deposition and avalanche damage due to its capacity to produce adventitious roots from the branches. Here, regenerative strategies determined the success of some species after disturbance. 

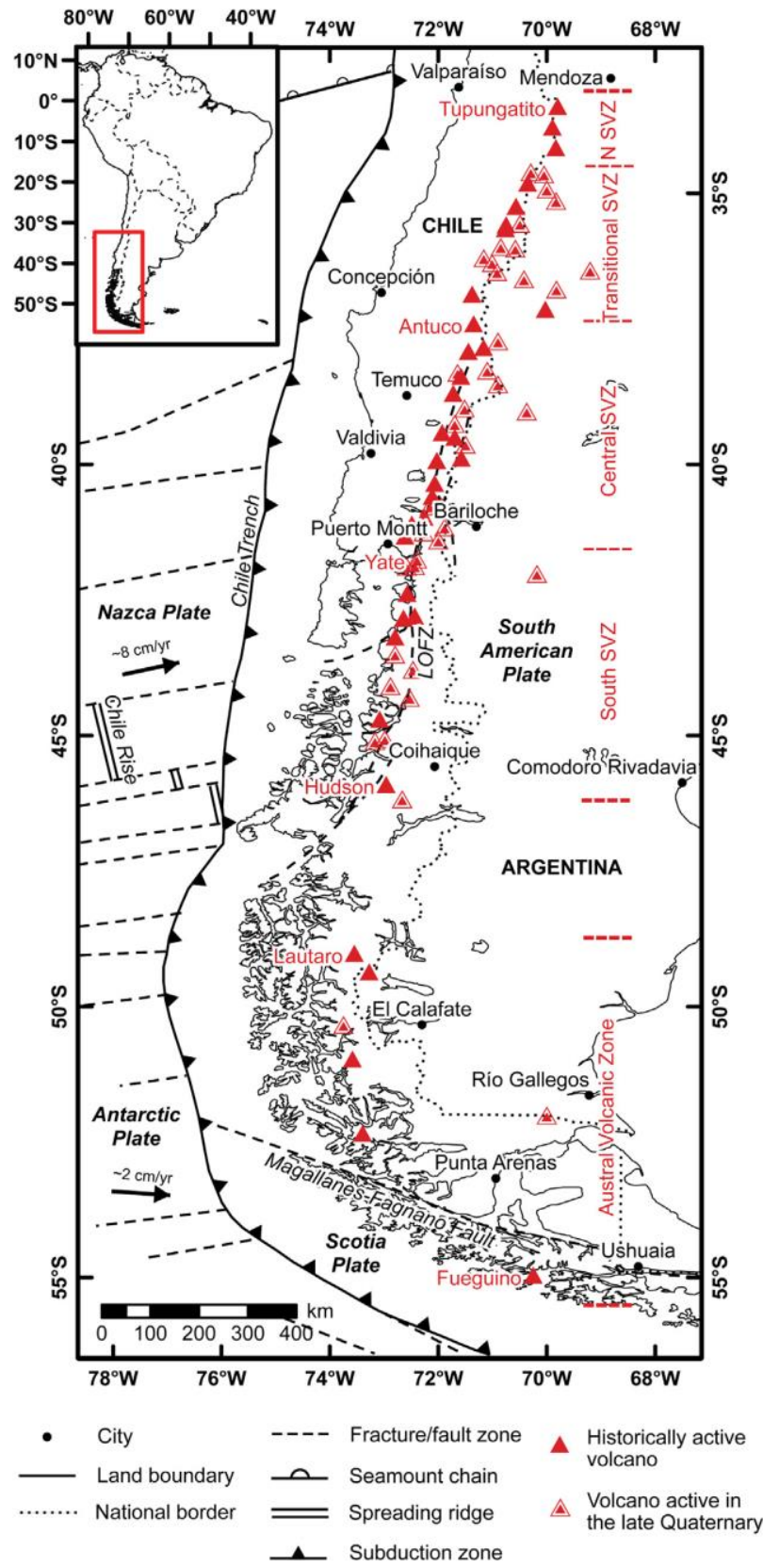

Figure 8. Map of the southern border between Chile and Argentina and the location of volcanos along the Andes Cordillera from Fontijn et al. (2014).

Swanson et al. (2013) analysed the consequences of the last eruption of the Chaitén volcano on the surrounding vegetation. They could distinguish several types of disturbance as well as differences in ecological responses to those disturbances. For example, within the blast zone (tree removal), the heat was moderate, abrasion and impact force were very high, and canopy loading was precluded. However, air fall tephra (fine tephra) had no effect in terms of heat, abrasion, and impact force, but canopy loading was high (Swanson et al., 2013). 


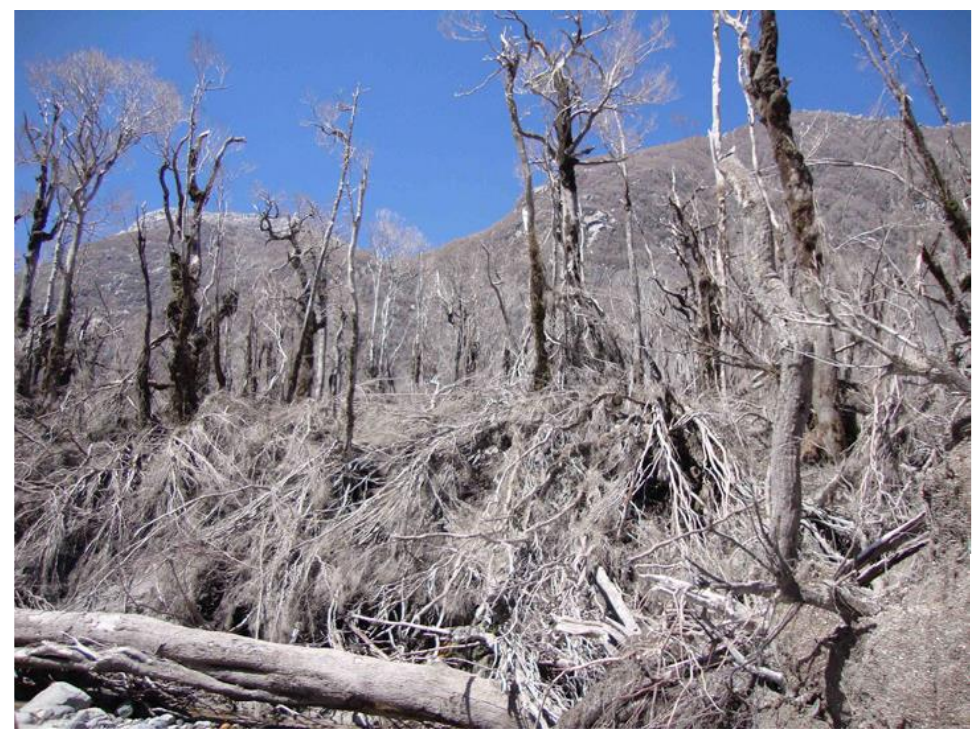

Figure 9. Consequences of the Chaiten eruption taken from Swanson et al. (2013) (Photo by J. Jones, January 2010).

The eruption of the Cordón Caulle volcanic complex in 2011 deposited up to $50 \mathrm{~cm}$ of tephra, given an opportunity to study disturbance effects at different tephra thickness scenarios on the vegetation. Once again, pre-eruption vegetation conditions and environmental factors somehow determine the ecosystem's responses during and after disturbance (Swanson et al., 2016). This is the case of tree-mortality differences between Nothofagus dombeyi and Nothofagus pumilio after tephra deposition. During the initial phases of the eruption (June-September, austral winter), $N$. pumilio trees were leafless and they experienced less mortality in comparison to the evergreen $N$. dombeyi, being the first species covered by $35 \mathrm{~cm}$ of tephra while the second species received just 10-25 cm of tephra. Swanson et al. (2016) concluded as follows: "tree species, age and season of eruption influence forest response along the gradient of tephra deposit thickness".

Despite the destructive impact of volcanic eruptions on the vegetation documented in several investigations, some plant taxa are able to persist this type of disturbance. The development of adventitious roots is a common example of plant regeneration strategies. Positive plant response to volcanic ash deposition was presented by Magnin et al. (2017). They assessed the impact on the length and radial growth of Nothofagus pumilio trees before and after tephra deposition. Interestingly, the length growth of $N$. pumilio trees increases significantly after the eruption in comparison to those trees of the same species located in greater distance to the volcano. The authors attribute this positive response probably as a result of an increase in water retention in the soil, to the facilitation of nutrients as well as to a decrease in herbivory and competition (Magnin et al., 2017). 
The effect of the Cordon Caulle volcanic complex eruption did not only affect areas tens of kilometres far from the source but also affected several Argentinean regions that were covered by ash fall transported by the westerlies. The effect of ash deposition in different climatic conditions, semi-arid steppe regions and temperate forest regions, along with an evaluation of the damage in infrastructure and agriculture, was analysed by Craig et al. (2016). Among their results, ash contamination of feed triggered the loss of livestock due to starvation, gastrointestinal and rumen blockages, and tooth abrasion. Remobilization of the ash fall deposit in steppe areas was detected months after the eruption. The authors emphasized the differences in the impact and damage of ash deposition according to the region (steppe or forest) as well as the condition of the environment before the ash fall deposition. In the case of steppe vegetation, a severe drought before the eruption have left pasture and livestock in poor conditions, and farm systems vulnerable, therefore the eruption maximized the losses in these regions. However, in forested areas precipitation rinsed the ashes from trees and facilitated the integration of ash into the soil and diminished the damage on the foliage (Craig et al., 2016).

All these examples of short-term responses to volcanic disturbances agree with the important role of vegetation conditions before disturbance, which makes the difference in terms of the damage of the disturbance event. In addition, the role of biological legacies in maintaining the vegetation and determining the type of succession (primary or secondary according to the magnitude of the event) is a common conclusion among the studies.

\subsection{Fire regimes in Patagonia}

Fires are one of the most important disturbance agents recognized around the world and their effect on ecosystems has been the focus of short-term analysis. Dendrochronological and palaeoecological studies attempt to assess the past fire regimes and their influence on vegetation at centennial and millennial scales. The role of fire in the development of certain plant species, plant communities, and secondary succession has been largely documented (Sphagnum: Kuhry, 1994; Austrocedrus chilensis and Nothofagus dombeyi: Dezzotti, 1996; Patagonian grasslands: Dudinszky and Ghermandi, 2013). Given the current climatic emergency, fire episodes have become more frequent and their magnitude increase. Drought and a decrease in precipitation are the primary causes of those changes in the fire regimes, and most certainly, anthropogenic influence. Most of the fire episodes occur during the Austral summer (December-March) due to lightning or humans and affect both forest and grassland. The extension of the fire depends mostly on the amount of available fuel 
and abiotic factors such as topography, elevation, and precipitation. For Patagonia, the dynamics and nature of the fire event (natural or anthropogenic) is an ongoing topic and has been analysed using proxies such as tree-rings, post-fire stamps, and micro- and macro charcoal particles collected in sediment cores. Nevertheless, satellite images and aerial photography are also used to compare fire regimes at decadal scales.

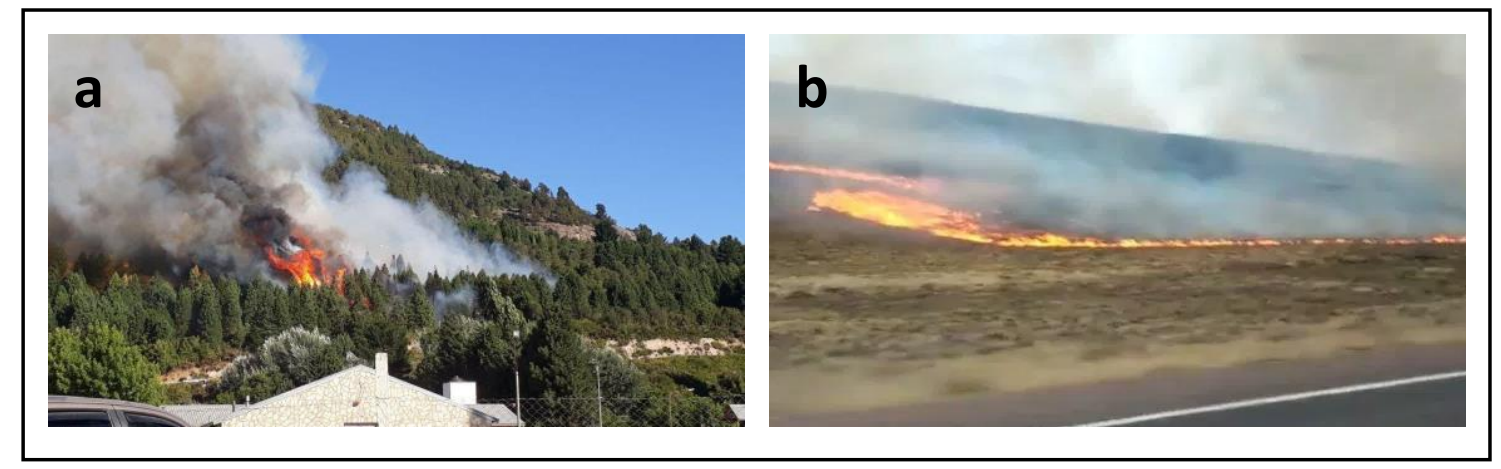

Figure 10. a) Fire in a slope with $A$. chilensis close to San Martín de los Andes city (Neuquén-Argentina) taken from Canal 5 Noticias (February $7^{\text {th }}, 2018$ ); b) Fire in the steppe nearby San Martín de los Andes, taken from Info Los Andes (2019).

Patterns of vegetation changes related to changes in the fire regimes have been largely analysed along the forest-steppe ecotone in northern Patagonia. Among the effect of fire on the vegetation is the conversion of forest to shrublands, documented by Mermoz et al. (2005). They sought the relation between pre-burn vegetation types and abiotic factors analysed at a broad scale, while the fire occurrence and fire spread at a fine scale. The results concluded that the fire extent has its maximum at intermediate elevation and areas with an intermediate amount of precipitation. In addition, tall shrublands are more affected by fire than the mesic forest of $N$. pumilio and $N$. dombeyi. Nevertheless, they conclude that anthropogenic ignitions and the positive feedback of fire and shrubland are accelerating conversion from forest to shrubland. Kitzberger and Veblen (1999) quantified the changes in northern Patagonia landscape associated with fire and they found a forest recovery after the cessation of intentional fires. Most of the areas affected by intensive fire did not kill all the species and biological legacies were important in the process of forest recovery with species characterized for being long-lived and obligated-seed dispersal that expanded even in areas that previously were dominated by short-lived resprouting shrubs.

Conversely, a shift from Nothofagus pumilio forest to fire-prone shrubland is suggested by Paritsis et al. (2014). Post-fire N. pumilio forest is more propense to fire than an unburned N. pumilio forest. Moreover, after fire the persistence of the $N$. pumilio forest might not be possible due to plant 
communities that grow after burning of $N$. pumilio forest are likely to experience a rapid drying of dead and live fuels and therefore, are more susceptible to burning again. This will lead to the development of shrubland which in turn is vulnerable to fire as well. Furthermore, since the seeddispersal of $N$. pumilio is low, a possible succession from shrubland to forest would take several decades (Veblen et al., 1996) and likely shrubland could burn again killing juveniles of N. pumilio avoiding their development.

There is no doubt that fire regimes behave differently in forest and steppe environments. Short- and long-term analyses of fire patterns within Nothofagus forest in northern Patagonia indicated that in general fires in these regions are characterized by the high intensity with vertical expansion due to the presence of the bamboo Chusquea, which dominates the understory in these ecosystems. This vertical expansion of fire reaches the canopy and can kill several individuals (crown fires). The frequency of fire episodes is low, probably because of the infrequent lightning strikes and of course, the humid conditions which might prevent the ignition (Mermoz et al., 2005).

Nonetheless, an increase in the frequency of fires during the last century is attributed to ENSO activity, especially during La Niña events (drought period) (Nanavati et al., 2019) and to the more frequent convective storms during summer that trigger lightning strikes In addition, during the initial stages of the European colonization, several hectares of forest where cut-down and burned in order to create pasturelands, being this activity also a cause in the increase in fire frequency during the past 200 years. Nowadays, fire suppression is successful since most of the areas that comprise Nothofagus forest correspond to National Parks where fires are controlled.

In xeric Austrocedrus forest and steppe areas, fire episodes also experienced changes in frequency before and after European colonization in Patagonia. Fire frequency was high before the arrival of European settlers due to the use of fire by indigenous populations in Patagonia with war and hunting purposes (Veblen and Lorenz, 1988). These arid environments were affected by surface fires as a result of the lower amount of horizontal and vertical fuel. Therefore, fires in these regions are of less magnitude in comparison with forest fires, although the frequency is high (González et al., 2014) Once European settlers arrived, these regions experienced a decrease in fire events. The causes of this decrease are attributed to the diminution of indigenous populations, as the result of governmental decisions in favour of the economic development and therefore, the use of steppe for livestock, the decrease in grass availability to ignitions and, to the active fire suppression (Veblen, 
2014). It has been reported that these changes in the fire regime in the Patagonian ecotone allow the expansion of Austrocedrus populations during the twentieth century (Veblen and Lorenz, 1988).

Overall, fire plays a key role in controlling the landscape in Patagonia, as well as contributing to the dynamics and succession of plant communities. The responses of vegetation to a fire event will depend eventually on the preconditions of the area affected, the magnitude and impact of the event which is related to fuel availability and flammability of the community, and the persistence of the vegetation after a fire (biological legacies).

\section{References}

Attiwill PM (1994) The disturbance of forest ecosystems: the ecological basis for conservative management. Forest Ecology and Management 63:247-300.

Begon M, Townsedn CR, Harper JL (2006) The Nature of the community: patterns in space and time. In Begon M, Townsend CR and Harper JL (eds), Ecology from individuals to ecosystems pp 469-498. Blackwell Publishing, United Kingdom.

Craig H, Wilson T, Stewart C, Outes V, Villarosa G, Baxter P (2016) Impacts to agriculture and critical infrastructure in Argentina after ashall from the 2011 eruption of the Cordón Caulle volcanic complex: an assessment of published damage and function threshold. Journal of Applied Volcanology 5(7):1-31. Ol 10.1186/s13617-016-0046-1

Crisafulli CM, Dale VH (2018) Ecological responses at Mount St. Helens: Revisited 35 years after the 1980 Eruption. Springer. New York.

Darwin, C (1839) Voyage of the Beagle. Penguin Books. London, England.

Dezzotti A (1996) Austrocedrus chilensis and Nothofagus dombeyi stand development during secondary succession, in northwestern Patagonia, Argentina. Forest Ecology and Management 89:125-137.

Dudinszky N, Ghermandi L (2013) Fire as a stimulant of shrub recruitment in northwestern Patagonian (Argentina) grassland. Ecological Research 28:981-990.

Fontijn K, Machowycz SM, Rawson H, Pyle DM, Mather TA, Naranjo JA, Moreno-Roa H (2014) Late Quaternary tephrostratigraphy of southern Chile and Argentina. Quaternary Science Reviews 89:7084.

González ME, Amoroso M, Lara A, et al. (2014) Ecología de disturbios y su influencia en los bosques templados de Chile y Argentina. In: Donoso C, González ME, Lara A (eds). Ecología Forestal. Bases para el manejo sustentable y conservación de los bosques nativos de Chile. p 411-502. Ediciones UACh, Valdivia-Chile.

González ME, Veblen TT, Sibold JS (2010) Influence of fire severity on stand development of Araucaria araucana- Nothofagus pumilio stands in the Andean cordillera of south-central Chile. Austral Ecology 35:597-615. 
Gutiérrez AG, Armesto JJ, Aravena JC (2004) Disturbance and regeneration dynamics of an oldgrowth North Patagonian rain forest in Chiloé Island, Chile. Journal of Ecology 92:598-608.

Kitzberger T (2012) Ecotones as Complex Arenas of Disturbance, Climate, and Human Impacts: The Trans-Andean Forest-Steppe Ecotone of Northern Patagonia. In: Ecotones between Forest and Grassland. R.W. Myster (ed.) New York. Springer Science+Bussiness Media, pp 59-88. DOI 10.1007/978-1-4614-3797-0_3.

Kitzberger T, Veblen TT (1999) Fire-induced changes in northern Patagonia landscape. Landscape Ecology 14:1-15.

Kuhry P (1994) The role of fire in the development of Sphagnum-dominated peatlands in western boreal Canada. Journal of Ecology 82:899-910.

Magnin A, Villalba R, Torres CD, Stecconi M, Passo A, Sosa CM, Puntieri JG (2017) Effect of volcanic ash deposition on length and radial growths of a deciduous montane tree (Nothofagus pumilio). Austral Ecology 42:103-112.

Mermoz M, Kitzberger T, Veblen TT (2005) Landscape influences on occurrence and spread of wildfires in Patagonia forest and shrubland. Ecology 86(10):2705-2715.

Nanavati WP, Whitlock C, Iglesias V, de Porras ME (2019) Postglacial vegetation, fire, and climate history along the eastern Andes, Argentina and Chile (lat. 41-55 ${ }^{\circ}$ S) Quaternary Science Reviews 207: 145-160.

Newman EA (2019) Disturbance ecology in the Anthropocene. Frontiers in Ecology and Evolution 7:1-147. doi: 10.3389/fevo.2019.00147

Paritsis J, Veblen TT, Holz A (2015) Positive feedbacks contribute to shifts from Nothofagus pumilio forest to fire-prone shrubland in Patagonia. Journal of Vegetation Science 26:89-101.

Rykiel ED Jr (1985) Towards a definition of ecological disturbance. Australian Journal of Ecology 10: 361-365.

Sottile GD, Meretta PE, Tonello MS, Bianchi MM, Mancini MV (2015) Disturbance induced changes in species and functional diversity in southern Patagonian forest-steppe ecotone. Forest Ecology and Management 353:77-86. http://dx.doi.org/10.1016/j.foreco.2015.05.025

Swanson FJ, Jones JA, Crisafulli CM, Lara A (2013). Effects of volcanic and hydrologic processes on forest vegetation: Chaitén Volcano, Chile. Andean Geology 40(2):359-391.

Tiribelli F, Kitzberger T, Morales JM (2017) Changes in vegetation structure and fuel characteristics along post-fire succession promote alternative stable states and positive fire-vegetation feedbacks. Journal of Vegetation Science 2018:1-11. DOI: 10.1111/jvs.12620

Turner MG, Dale VH, Everham EH (1997). Fires, Hurricanes, and Volcanoes: Comparing large disturbances. BioScience 47(11):758-768.

Veblen TT (2014) Fuego y cambios del paisaje cerca del ecotono de la estepa y los bosques en el norte de la Patagonia, Argentina. In: Donoso C, González ME, Lara A (eds). Ecología Forestal. Bases para el manejo sustentable y conservación de los bosques nativos de Chile. $p$ 441-443. Ediciones UACh, Valdivia-Chile. 
Veblen TT, Armesto JJ, Burns BR, Kitzberger T, Lara A, León B, Young KR (1995) The coniferous forest of South America. In: Andersson F (ed). Ecosystems of the World 6: coniferous forest. Elsevier, pp 701-725.

Veblen TT, Lorenz DC (1988) Recent Vegetation Changes along the Forest/Steppe Ecotone of Northern Patagonia, Annals of the Association of American Geographers 78(1):93-111. DOI: 10.1111/j.1467-8306.1988.tb00193.x

Veblen TT, Lorenz DC (1987) Post-fire stand development of Austrocedrus-Nothofagus forest in northern Patagonia. Vegetatio 71:113-126.

Veblen TT, Schlegel FM, Escobar B (1980) Structure and dynamics of old-growth Nothofagus forest in the Valdivian Andes Chile. Journal of Ecology 68:1-31.

Veblen TT, Ashton DH, Schlegel FM, Veblen AT (1977) Plant succession in a timberline depressed by vulcanism in south-central Chile. Journal of Biogeography 4:275-294.

White PS, Pickett STA (1985). Natural disturbance and patch dynamics: an introduction. In: Pickett STA and White PS (eds) The Ecology of Natural Disturbance and Patch Dynamics. Academic Press, New York 3-13. doi: 10.1016/B978-0-12-554520-4.50006-X 


\section{Chapter 4: Palaeoecology and Palynology}

\subsection{What is palaeoecology? General concepts}

Palaeoecology is the ecology of the past (Birks and Birks, 1980). In general, this discipline combines multiple source of information, such as biological, molecular and geochemical in order to study the relationship and interactions of organisms in all their level of associations and their environment, together with all the functional processes that makes possible their existence in a physical place (Odum and Barrett, 1971), the palaeoecology attempt to analyse and understand those interaction in ancient times through the use of proxies (pollen, charcoal, diatoms, phytoliths, macro remains, ostracods, etc); in others words: the branch of ecology that studies (the) past (of) ecological systems and their trends in time using fossils and other proxies (Rull, 2010).

A general assumption among palaeoecologist is that "the present is the key to the past". This concept implies Lyell's uniformitarian principle where it is assumed that the ecological responses of species do not changes through their histories. Further discussion and philosophical implications about this topic are deeply examined by Scott (1963). Despite the still discussion about the meaning and theoretical implications of the term, the key goal of this discipline is to reconstruct past species and communities from fossil evidence and, by definition, a palaeoecological survey should have an ecological aim (Rull, 2010).

\subsection{Links between palaeoecology, ecology, and nature conservation}

As palaeoecology use the frame of knowledge from the ecology, there are three main key questions or information that palaeoecologist need from ecologist according to Huntley (1996): 1) the overall geographical distribution and in what plant communities the species occurs; 2) the autecological characteristics of the species, especially regeneration and; 3 ) the factors (biotic or abiotic) that determine the distribution of the species. Having this information, the palaeoecologist is able to develop an accurate and reliable interpretation from the assemblages obtained by the indicator/proxy used. Among the goals that the palaeoecology involves is the reconstruction of the past biota, past communities, past landscapes, and ecosystems, as well as past environment, which include the climate and human impact. All these objectives are closely linked with the topics addressed by an ecologist.

One of the many applications that palaeoecology can provide to modern ecology and ecosystem management is in the field of nature conservations. In that respect, Birks (1996) developed this 
matter emphasising the contributions of palaeoecology to conservationism, like the assessment of naturalness and fragility of ecosystems; especially the last point due to human activities and other biotic factors; evaluation of the conservation status of rare species, through the contribution of basic information and understanding of the causes of recent decline of taxa; and through the contribution of baseline data about past ecosystem composition and function. A recent discussion about the role of palaeoecology in conservation biology is addressed by Birks (2012). The author calls for a "strong and effective collaboration between palaeoecology and conservation" and highlights the contribution of palaeoecology to the temporal dimension of ecosystem services and goods and to the fact that this field of science has demonstrated that landscapes and biota are not static entities.

\subsection{Palynology and past vegetation reconstructions}

Palynology is the study of pollen and spores, although inside this category are included organism or part of an organism that falls in the spore-pollen size range, like diatoms, dinoflagellates, foraminifera, among others (Walker and Doyle, 1975). The pollen features, such as type of aperture, pollen wall architecture, pollen unit, polarity, symmetry, shape, and grain size are used in order to determine the taxonomical level (family, genus, species). The resistance of the pollen wall is key in the preservation of this grain in ancient sediment deposits (Shaw, 1970). Since a pollen grain belongs to some taxonomical level, palynology is useful in the field of botany, biogeography, and ecological research. Moreover, it has become a fundamental tool to "unravel the ecological and environmental trends and changes through the Quaternary" (Rull et al., 2018).

Since plant communities respond to environmental factors, a detailed description of the lithology of the cores, the analysis of non-pollen palynomorphs and macro charcoal remains are necessary in order to reconstruct the past disturbance regimes (volcanic ash deposition and fires) and the environmental conditions that triggered the observed changes. This multiproxy approach allows a better examination and reconstruction of past vegetation and environment, and it was used in the investigations presented in the Chapters 5, 6, and 7. The schematic synthesis of this perspective is shown in Figure 11. 


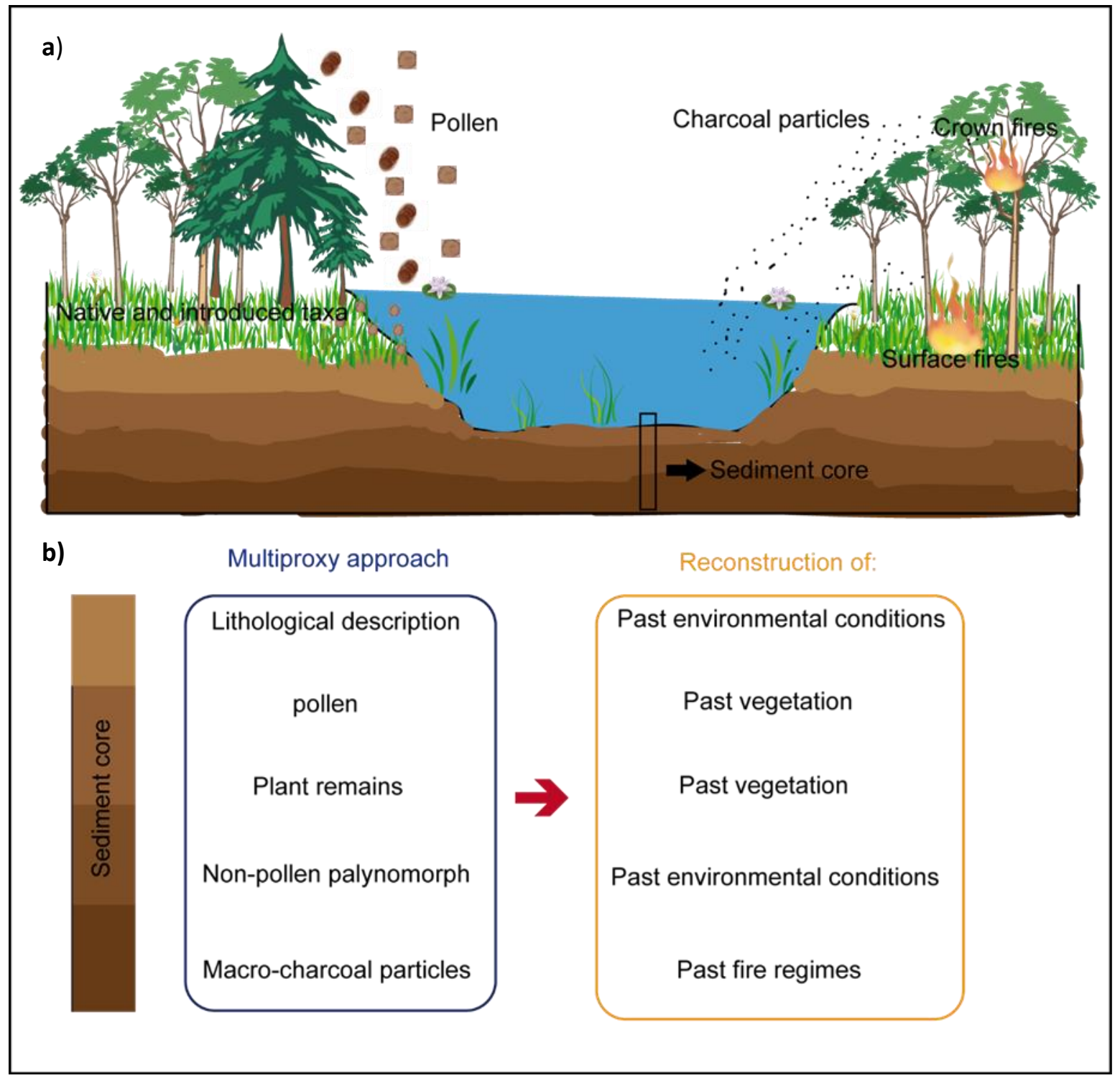

Figure 11. Schematic representation of the multiproxy approach used in this thesis. a) Schematic representation of the phenomena captured in small lakes (fires, local vegetation, human impact). b) Multiproxy approach conducted in the present work and the possible reconstructions. 
The multiproxy approach is the main technique available for determining vegetation response to past terrestrial environmental change (Bennett and Willis, 2002). The general methodology used in palaeoecology and therefore in the present work is schematized in Figure 12.

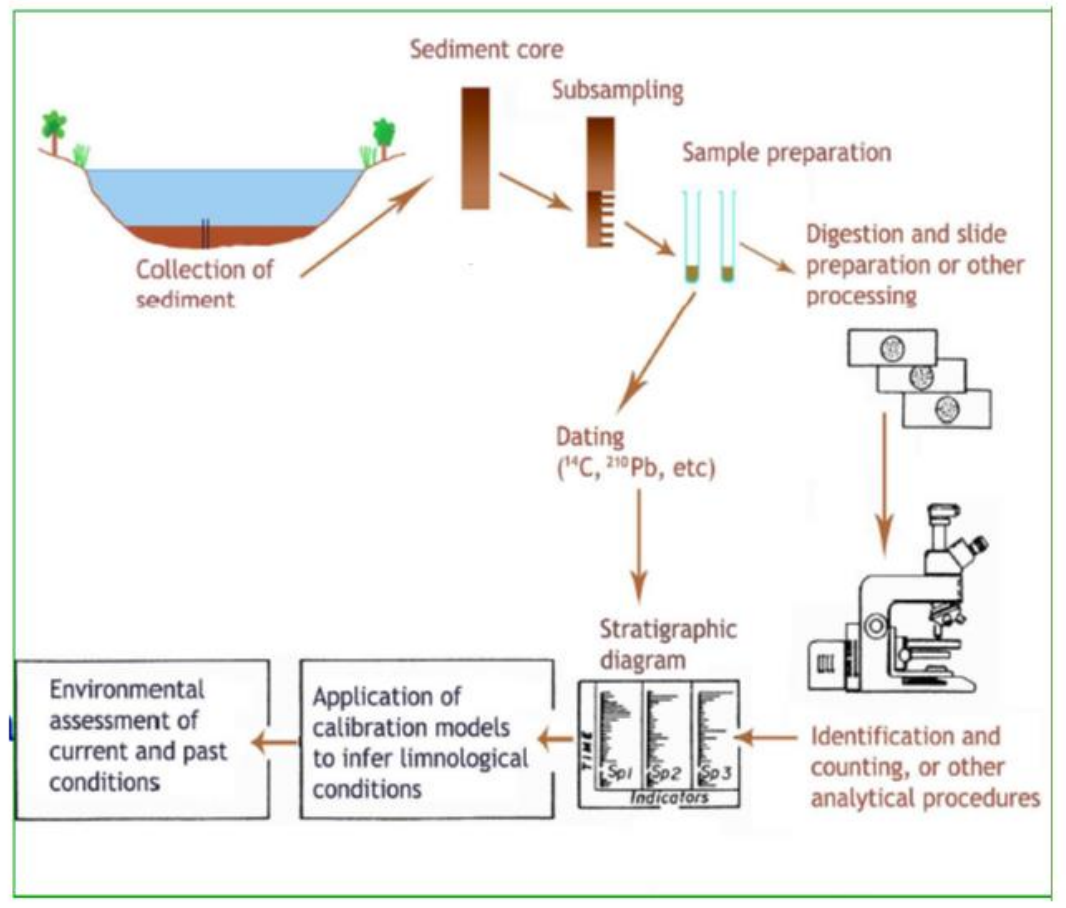

Figure 12. Schematic representation of the procedure in a palaeoecological study. Extracted from Birks and Birks (2011).

\section{References}

Bennett KD, Willis KJ (2002) Pollen. In Smol JP, Birks HJB, Last WM (eds). Tracking environmental change using lake sediments. Volume 3: Terrestrial, Algal, and Siliceous indicators. p 5-32.

Birks HJB (2012) Ecological palaeoecology and conservation biology: controversies, challenges, and compromises, International Journal of Biodiversity Science, Ecosystem Services \& Management 8 (4):292-304. DOI: 10.1080/21513732.2012.701667

Birks HJB (1996) Contributions of Quaternary palaeoecology to nature conservation. Journal of Vegetation Science 7:89-98.

Birks, HJB \& Birks, HH (1980) Quaternary Palaeoecology. Edward Arnold, London.

Huntley B (1996) Quaternary palaeoecology and ecology. Quaternary Science Review 15:591-606.

Rull V, Montoya E, Giesecke T, Morris JL (2018) Editorial: Palynology and Vegetation History. Frontiers in Earth Science 6(9):1-3 doi: 10.3389/feart.2018.00186

Rull V (2010) Ecology and Palaeoecology: Two Approaches, One Objective. The Open Ecology Journal 3:1-5. 
Scott GH (1963) Uniformitarianism, the uniformity of nature, and paleoecology. New Zealand Journal of Geology and Geophysics 6(4):510-527. DOI: 10.1080/00288306.1963.10420063

Shaw G (1970) The chemistry of sporopollenin. Sporopollenin. Proceedings of a Symposium Held at the Geology Department, Imperial College, London, 23-25 September 1970. p 305-350. Academic Press.

Seddon AWR et al. (2014) Looking forward through the past: identification of 50 priority research questions in palaeoecology. Journal of Ecology 102:256-267.

Walker JW, Doyle JA (1975) The bases of angiosperm phylogeny: palynology. Annals of the Missouri Botanical Garden 62(3):664-723. 


\section{Chapter 5}

\section{Late Holocene vegetation dynamics and disturbance regimes in north Patagonia Argentina $\left(40^{\circ} \mathrm{S}\right) *$}

* This chapter correspond to a Manuscript submitted to The Holocene journal. It was accepted for publication on August 2019. The authors are:

1. Valentina Álvarez Barra (Corresponding Author)

(Department of Palynology and Climate Dynamics, University of Göttingen, Germany)

2. Thomas Giesecke

(Department of Palynology and Climate Dynamics, University of Göttingen, Germany; Department of Physical Geography, Faculty of Geosciences, Utrecht University, Netherlands)

3. Sonia L. Fontana

(Department of Palynology and Climate Dynamics, University of Göttingen, Germany) 


\section{Abstract}

Natural disturbance processes such as volcanic eruptions, fire, and human activities are important vegetation drivers in north Patagonia. Here, we tested the impact of volcanic ash fall and fire on vegetation composition analysing two sediment records, Lake Avutarda and Lake Bruja located in the forest-steppe transition at $40^{\circ} \mathrm{S}$. Additionally, our analysis provides the first account on the history of Nothofagus alpina at its eastern distribution limits. Our results comprise the last 3000 years, indicating the persistence of the vegetation despite evident volcanic activity documented by numerous tephra layers in both records. Eleven fire episodes were identified, while redundancy analysis indicates a non-significant influence of fire activity on the vegetation. The population increase of Nothofagus alpina represents the most important change in vegetation composition in the last three millennia. We speculate that the presumed change in climate, which lead to the expansion of Austrocedrus chilensis south of the study area, also caused the increase of Nothofagus alpina populations in the region.

Key words: Late Holocene, ash, fire, human activities, Nothofagus alpina.

\subsection{Introduction}

The eastern side of the Patagonian Andes is characterized by a remarkable vegetation gradient, with a sharp transition from the forest to the steppe. The modern geographic position of the ecotone is largely determined by effective moisture and follows the decrease in precipitation from west-toeast (Garreaud, 2009), which in turn is determined by the orographic effect of the Andes Cordillera and the prevailing westerly winds. The exact position of the ecotone may depend on the latitudinal position and strength of the Southern Westerlies (Villalba et al., 2003). Nevertheless, natural disturbances such as fires and volcanic eruptions are frequent in this region and may play an important role in controlling the vegetation composition as well (Kitzberger, 2012; Veblen et al., 1992).

Many characteristics of the vegetation, including richness, dominance, and structure are under the influence of disturbance events (Pickett and White, 1985; Theurillat and Guisan, 2001). The strength or frequency of some disturbance processes depend on the mean state of other abiotic components (Baker, 1995; Turner et al., 1998). For example, the severity and frequency of fire varies with changes in precipitation and temperature (Dale et al., 2001; Jolly et al., 2015; Veblen et al., 2000). 
Additionally, human activities represent additional disturbance factors, such as logging, animal pasture and through the introduction of new species.

In addition to climate and disturbance regimes controlling vegetation history, the initial distribution of plants at the end of the last glaciation play an important role in explaining postglacial vegetation change. The survival of plants on both sides of the Andes Cordillera has been proposed by palynological and genetics studies, for some important tree taxa in the region (Heusser, 1983; Marchelli and Gallo, 2006; Markgraf et al., 2009; Paredes, 2003; Pastorino and Gallo, 2002; Premoli et al., 2000; Villagrán, 1991). Nothofagus alpina has been largely investigated in genetic studies (Donoso et al., 1990; Marchelli and Gallo, 2004), while palaeoecological studies have hitherto not addressed its history along its eastern distribution limit, especially at $40^{\circ} \mathrm{S}$, where Nothofagus alpina as well as Nothofagus obliqua (same pollen type) have their largest abundance (Sabatier et al., 2011).

These deciduous southern beech species occur at both sides of the Andes Cordillera. The latitudinal range of Nothofagus alpina in Chile extends from $35^{\circ} 13^{\prime} \mathrm{S}$ until $40^{\circ} 22^{\prime} \mathrm{S}$ and its Argentinean distribution comprises a latitudinal range from $39^{\circ} 25^{\prime} \mathrm{S}$ to $40^{\circ} 35^{\prime} \mathrm{S}$. The geographical distribution of Nothofagus obliqua is wider extending in Chile from $30^{\circ} 30^{\prime} \mathrm{S}$ to $41^{\circ} \mathrm{S}$ and, on the eastern side of the Andes, its distribution ranges from $36^{\circ} 50^{\prime} \mathrm{S}$ to $40^{\circ} 15^{\prime} \mathrm{S}$. In general, both species growth under a humid-temperate climate, where winter precipitation plays an important role in the development and persistence of these species during the following summer (Donoso, 2013).

Based on these settings and previous research in the region we address the following questions: 1 ) What changes did the vegetation experience at $40^{\circ} \mathrm{S}$ during the last 3000 years? 2) Did natural and anthropogenic disturbances processes strongly influence vegetation composition through time? 3) What is the history of Nothofagus alpina in Northern Patagonia? To answer these questions, we investigated the sediments of two small lakes positioned in the transition of the forest-steppe ecotone, south of Lake Lácar in the Neuquén Province, Argentina. The area is currently largely affected by the deposition of volcanic ash, lightning and resulting fires, and human activities. Our study sites are located within the Lanín National Park, home to the main populations of Nothofagus alpina and Nothofagus obliqua on the eastern side of the Andes. 


\subsection{Modern environmental setting}

The study sites are located in north Patagonia Argentina at $40^{\circ} \mathrm{S}$, on the eastern flank of the Andes Cordillera, in the southwestern part of the Neuquén Province. The western flanks of the Andes receive precipitation in excess of $3000 \mathrm{~mm}$ a year, which drops within $100 \mathrm{~km}$ to below $200 \mathrm{~mm}$ per year. The air masses discharge most of the humidity on the way up the mountains on the western slopes of the Andes. Dry air descends on the eastern slopes undergoing adiabatic heating: due to the difference between wet and dry lapse rates the descending air is warmer. In the valleys, precipitation is generally less than $800 \mathrm{~mm}$ (Garreaud et al., 2013). Maximum precipitation occurs in the winter season (June-August). To the east, the climate is drier and with regular frost periods and warmer summer temperatures (Fernández-Long and Müller, 2006). In the study area, the average precipitation varies between 2100 and $1700 \mathrm{~mm}$ per year. The average temperatures are $4.1^{\circ} \mathrm{C}$ in winter and $20.1^{\circ} \mathrm{C}$ in summer (Administración de Parques Nacionales, 2012).

The vegetation in the region responds to the sharp precipitation gradient and topography. A vegetation transition from rain forest to open woodland and to steppe on the eastern flanks characterize this gradient. The rainforest elements Podocarpus nubigenus, Saxegothaea conspicua, Drimys winteri are present in the westernmost areas. (Donoso, 2013). The transition zone between rain forest and the steppe is dominated by an open woodland of Nothofagus antarctica with Austrocedrus chilensis and Maytenus boaria together with shrub species of Berberis, Discaria, and Escallonia. The steppe is mainly characterized by shrubs belonging to the family Asteraceae, Chenopodiaceae, and to the genus Mulinum and herbs of Poaceae, Senecio, Acaena, and Phacelia.

The forest is dominated by several southern beech species of the genus Nothofagus. Their distribution in the landscape is determined by effective moisture, elevation, and soil. Five species of Nothofagus are present in the region, of which Nothofagus alpina and Nothofagus obliqua are restricted to some lake basins in their Argentinean distribution. Large and dense mixed forests of these two species develop around Lake Lácar (Sabatier et al., 2011) while in other overlapping areas of their distribution the two species occur as monospecific forests. Within those mixed forests however, the species abundance differs with altitude. Nothofagus obliqua dominates the forests between 650 and $800 \mathrm{~m}$ a.s.I., while Nothofagus alpina becomes dominant at $950 \mathrm{~m}$ a.s.l., occurring up to $1350 \mathrm{~m}$ a.s.l. Nothofagus alpina grows under an annual precipitation average between 1800 and $2800 \mathrm{~mm}_{\text {year }}{ }^{-1}$ and Nothofagus obliqua occurs with a precipitation average between 950 and $2300 \mathrm{~mm}$ year $^{-1}$ (Sabatier et al., 2011). Nothofagus alpina extends its south range of distribution in 
Argentina to $40^{\circ} 35^{\prime} \mathrm{S}$, while Nothofagus obliqua reaches its southern limit of distribution at $40^{\circ} 14^{\prime} \mathrm{S}$, south of the Lake Lácar basin. In Argentina, Nothofagus alpina is more than twice as abundant as Nothofagus obliqua.

The other three Nothofagus species have a wider distribution in Argentina as well in Chile. Nothofagus pumilio is a deciduous tree widely distributed along the Andes in Argentina and Chile (Donoso, 2013), defining the upper tree limit at high altitudes (Cuevas, 2000). Different morphological forms occur according to the altitude and environmental conditions, with some individuals growing as shrubby krummholz form at the highest elevations and others growing as trees up to $20 \mathrm{~m}$ tall (Young and Leon, 2007). Nothofagus dombeyi dominates slopes in the western parts in an elevation belt below Nothofagus pumilio, where the mean annual precipitation fluctuates between 1000 and $2800 \mathrm{~mm}$. Nothofagus antarctica, possesses the greatest ecological amplitude among the South American Nothofagus species (Donoso, 2013) and adopts different morphotypes according to the environment in which it develops (Premoli, 1991; Ramírez and Figueroa, 1987). In our study site, this species is forming monospecific woodland and mixed patches of open vegetation towards the dry end of the precipitation gradient.

The study sites are located within the Lanín National Park in Neuquén Province, Argentina (Figure 13c). Lake Bruja ( $40^{\circ} 14^{\prime} \mathrm{S} ; 71^{\circ} 30^{\prime} \mathrm{W} ; 1060 \mathrm{~m}$ a.s.I.; Figure $13 \mathrm{~b}$ ), is situated on the northeast slope of Cerro Escondido. It has a basin of about 1.6 hectares. It is located in a wide valley, which is used for summer pasture of cows, and horses that roam in the forest around the lake. The immediate surroundings of the lake consist of a closed mixed forest of Nothofagus dombeyi and Nothofagus alpina with few individuals of Nothofagus antarctica growing at the lake shore, while a mosaic of Nothofagus antarctica and patches of open grassland characterize the lower slopes and valley bottom. A dense population of bamboo Chusquea culeou characterizes the understory. Austrocedrus chilensis is present within the valley on slopes with northerly aspects. At Lake Bruja precipitation is about $2100 \mathrm{~mm}_{\text {year }}{ }^{-1}$.

Lake Avutarda (40 $23^{\prime} \mathrm{S} ; 71^{\circ} 25^{\prime} \mathrm{W} ; 1610 \mathrm{~m}$ a.s.I.; Figure $13 \mathrm{a}$ ) is located $30 \mathrm{~km}$ south of San Martin de Los Andes, east of Cerro Ezpeleta. It is situated at the treeline of Nothofagus pumilio. Nothofagus alpina occurs on the western slopes up to about $1350 \mathrm{~m}$ a.s.I. It is a shallow lake of 0.75 hectares, with a depth of $1.5 \mathrm{~m}$ at the time of sampling. Shrubs and herbs such as Asteraceae, Caryophyllaceae, Iridaceae, Poaceae, Ranunculaceae, Valeriana, Geranium, Acaena, Brassicaceae, Gaultheria, Senecio and Quinchamalium occur around the lake. Krummholz forms of Nothofagus 
pumilio grow at the eastern side of the lake, while a forest of erect Nothofagus pumilio trees is found to the west. At Lake Avutarda precipitation is about $1700 \mathrm{~mm}_{\mathrm{m}} \mathrm{ear}^{-1}$.

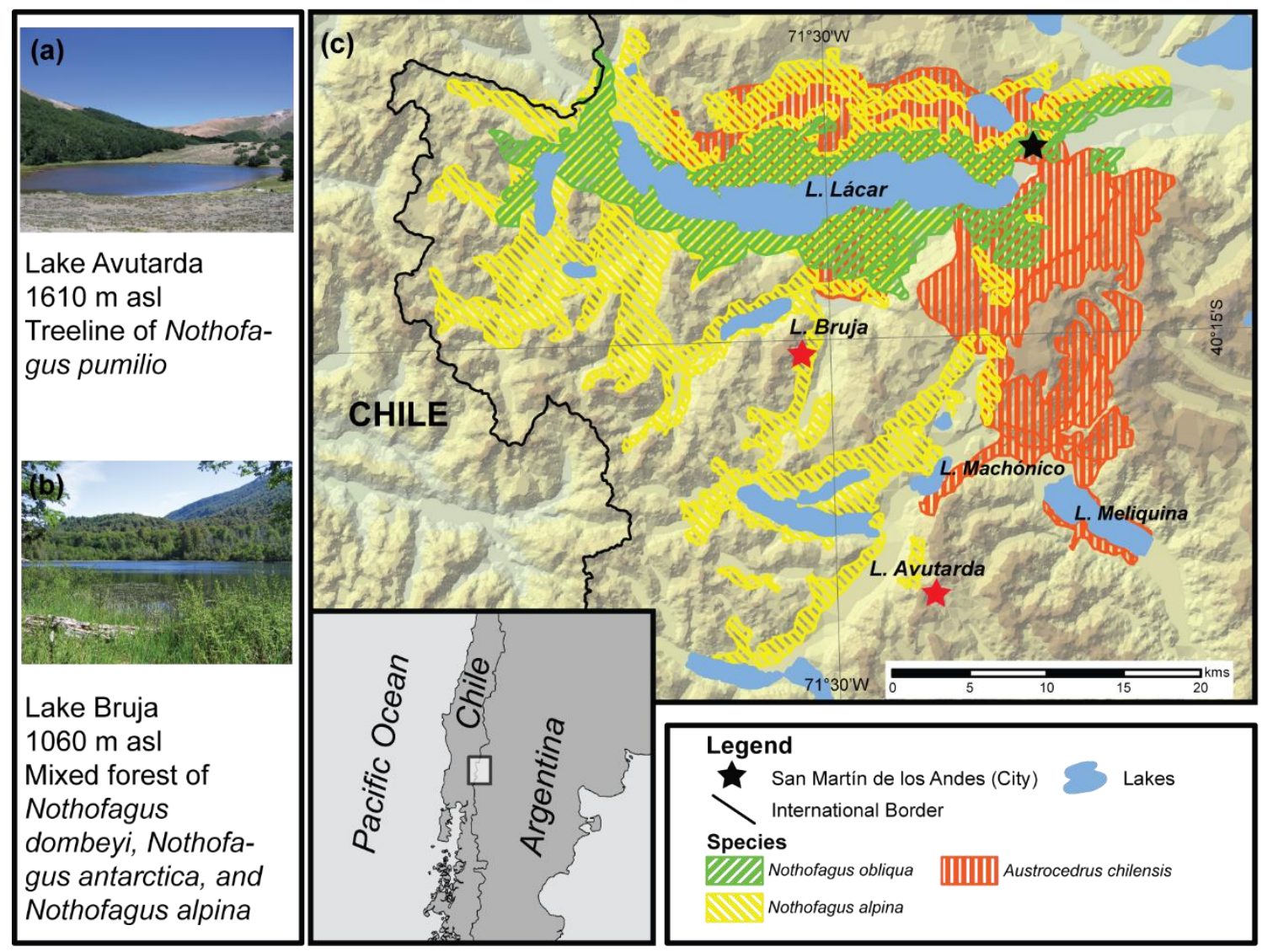

Figure 13. Location of the study sites: (a) Lake Avutarda and (b) Lake Bruja photographs; (c) position of the study sites (red stars), and the actual modern distribution of Nothofagus alpina, Nothofagus obliqua and Austrocedrus chilensis on the Argentinean side around Lake Lácar basin based on Sabatier et al. (2011); Administración de Parques Nacionales (2012); and Dezzotti and Sancholuz (1991). Notice that the studied lakes are small (Avutarda 0.75 and Bruja 1.6 hectares), and therefore not distinguishable on the map.

\subsection{Material and Methods}

The sediment-water interface at both lakes was collected using a gravity sampler, recovering $17 \mathrm{~cm}$ and $11 \mathrm{~cm}$ for Lake Bruja and Lake Avutarda, respectively. Further one-meter long core sections were obtained using a square rod Livingstone sampler (Wright, 1967). A $140 \mathrm{~cm}$ long core was obtained from Lake Bruja and a sediment sequence of $116 \mathrm{~cm}$ length was recovered from Lake Avutarda. Cores were described visually using the Munsell Soil Colour Chart. Loss on ignition was carried out at $550^{\circ} \mathrm{C}$ (Heiri et al., 2001) from the same sample depth used for pollen analysis.

Samples of $0.5 \mathrm{~cm}^{3}$ were taken for pollen analysis at $2 \mathrm{~cm}$ intervals, along both cores avoiding tephra layers. In addition, contiguous pollen sampling was conducted before and after major tephra layers 
in order to analyse the effect of ash deposition on the vegetation. Pollen processing followed the methodology outlined by Bennett and Willis (2001), excluding sieving. Identification was carried out using the reference collection from the Department of Palynology and Climate Dynamics of the University of Göttingen together with reference literature by Heusser (1971) and Markgraf and D'Antoni (1978). A tracer of Lycopodium was added to each sample to calculate pollen concentration. A minimum of 500 pollen grains was counted at $40 \times$ magnification. Terrestrial pollen percentages were based on the sum of trees, shrubs, and herbs. Cyperaceae pollen grains were not included in the sum of aquatic taxa since these plants grow at the margin of the lakes.

In the absence of macrofossils, four bulk sediment samples per lake were radiocarbon dated. The age-depth models were constructed based on these dates (Table 1) and pollen stratigraphical control points using Clam 2.2 (Blaauw, 2010) with SHCal13.14C calibration curve (Reimer et al., 2013). Linear interpolation was applied, without considering the width of tephra layers with a thickness $>1 \mathrm{~cm}$.

Table 1. Radiocarbon ages for the cores Avutarda and Bruja based on bulk sediment. Control points based on first pollen appearance: $\mathrm{CPa}$ marks the establishment of Pinus plantations. $\mathrm{CPb}$ arrival of first European settlers indicated by Rumex acetosella.

\begin{tabular}{|c|c|c|c|c|c|}
\hline Depth $(\mathrm{cm})$ & $\begin{array}{l}\text { Uncalibrated } \\
\text { age }\end{array}$ & $\begin{array}{l}\text { Calibrated } \\
\text { age (cal. yr } \\
\text { BP) }\end{array}$ & $\begin{array}{l}\text { Calibrated ages ranges at } \\
95 \% \text { confidence intervals } \\
\text { (yr } \quad \mathrm{min} / \mathrm{yr} \quad \max \\
\text { [probability (\%)] }\end{array}$ & $\begin{array}{l}\text { Control } \\
\text { point }\end{array}$ & Laboratory code \\
\hline \multicolumn{6}{|c|}{ Lake Avutarda } \\
\hline $150.5-151$ & & -30 & $-49 /-11[95]$ & $1970 \pm 20$ & $\mathrm{CPa}$ \\
\hline 153.5-154 & & 71 & 21/118 [95] & $1880 \pm 10$ & $\mathrm{CPb}$ \\
\hline $167.5-168$ & $1229 \pm 25$ & 1103 & $\begin{array}{l}993 / 1017 \text { [7] } \\
1054 / 1179 \text { [87.9] }\end{array}$ & & UBA-19650 \\
\hline 200.5-201 & $1944 \pm 26$ & 1846 & $\begin{array}{l}1747 / 1772[9.8] \\
1789 / 1791[0.4] \\
1801 / 2086[84.7]\end{array}$ & & UBA-19652 \\
\hline 219.5-220 & $2088 \pm 28$ & 2007 & $\begin{array}{l}1930 / 1979[27.3] \\
1981 / 2086[67.6]\end{array}$ & & UBA-19654 \\
\hline $263-263.5$ & $2708 \pm 50$ & 2792 & $\begin{array}{l}2720 / 2879[94.8] \\
2914 / 2915[0.2]\end{array}$ & & UBA-19656 \\
\hline \multicolumn{6}{|l|}{ Lake Bruja } \\
\hline $685.5-686$ & & -30 & $-49 /-11$ [95] & $1970 \pm 20$ & $\mathrm{CPa}$ \\
\hline $687.5-688$ & & 70 & $31 / 108$ [95] & $1880 \pm 10$ & $\mathrm{CPb}$ \\
\hline
\end{tabular}




\begin{tabular}{|l|l|l|l|l|}
\hline $\mathbf{7 1 5 - 7 1 5 . 5}$ & $837 \pm 41$ & 709 & $\begin{array}{l}670 / 752[94.2] \\
758 / 760[0.8]\end{array}$ & UBA-21609 \\
\hline $\mathbf{7 4 7 - 7 4 7 . 5}$ & $1761 \pm 45$ & 1721 & $1537 / 1722[95]$ & UBA-21610 \\
\hline $\mathbf{7 9 2 . 5 - 7 9 3}$ & $1963 \pm 35$ & 1867 & $1748 / 1772[5.7]$ & UBA-21611 \\
& & & $1788 / 1791[0.4]$ & $1800 / 1933[84]$ \\
& & & $1963 / 1992[4.8]$ & \\
\hline $\mathbf{8 3 6 - 8 3 6 . 5}$ & $3359 \pm 33$ & 3543 & $3455 / 3636[95]$ & UBA-21612 \\
\hline
\end{tabular}

Pollen diagrams were constructed using C2 (Juggins, 2003). Constrained cluster analysis was performed with Tilia 2.0 (Grimm, 1993) using incremental sum of squares on the chord distance matrix. Principal component analysis (PCA) was conducted to explore directional changes and compare the two sites. The analysis was carried out on the covariance matrix of the taxon-combined percentage data. We conducted a redundancy analysis (RDA) examining possible relationships between changes in the vegetation composition and tephra deposition as well as fire episodes. The distance of each sample to the prior tephra layer and tephra thickness are the variables considered to evaluate whether tephra deposition had an effect on the vegetation. Fire frequency and fire magnitude are the variables used to investigate if the fire regime had influenced the vegetation. All ordinations were performed using CANOCO 5.0 (Ter Braak and Šmilauer, 2012) with square root transformed percentage data. For visual comparison, samples from both lakes were assigned to the clusters corresponding to the numerical zonation of each record. Palynological richness (E(Tn)) (Birks and Line, 1992) was estimated using 'vegan' package version 2.4.4 (Oksanen et al., 2017) with R (R Development Core Team, 2017).

Macro charcoal analysis was carried out based on $1 \mathrm{~cm}^{3}$ sediment contiguously sampled at a $1 \mathrm{~cm}$ interval following the methodology outlined by Stevenson and Haberle (2005), avoiding tephra layers. The material was sieved at $125 \mu \mathrm{m}$ and counted under a stereomicroscope. The results were analysed using CharAnalysis (Higuera et al., 2009). This analysis was carried out for Lake Bruja, due to its position within a major forest of Nothofagus species. 


\subsection{Results}

\subsubsection{Chronology, Lithology, and Loss on Ignition}

The age-depth models for the cores from Avutarda and Bruja indicate basal ages of 2800 and 3600 cal. yr BP, respectively (Figure 14a and b). To constrain the age model for the youngest samples, we added two control points. A date of $1880 \pm 20$ was added for the arrival of the first European settlers to the area (Kitzberger, 2012; Veblen and Lorenz, 1988), indicated by the onset of the Rumex acetosella curve in the diagram. A second date was used to mark the onset of Pinus plantations in the region (1970 \pm 10) (Rehfeldt and Gallo, 2001; Schlichter and Laclau, 1998).

Table 2. Sediment description of cores Avutarda and Bruja.

\begin{tabular}{|c|c|c|}
\hline Depth $(\mathrm{cm})$ & Age cal. yr BP & Sediment characteristics \\
\hline \multicolumn{3}{|c|}{ Lake Avutarda } \\
\hline 150-145.5 & Present & Clay. LOI between 5 and $22 \%$. \\
\hline 181-150 & 1150-Present & Alternate gyttja/black-basaltic ash layers. LOI between 2 and $12 \%$. \\
\hline 191-181 & $\sim 1550$ & Grey-pumice-rich segment. \\
\hline 236-191 & 2300-1550 & $\begin{array}{l}\text { Alternate clayey-gyttja/black-basaltic ash layers. LOI between } 1 \text { and } \\
20 \% \text {. Minimum LOI \% between } 213-203 \mathrm{~cm} \text {. }\end{array}$ \\
\hline 253-236 & $\sim 2300$ & Thick grey-pumiceous segment. \\
\hline $265-253$ & $2800-2300$ & $\begin{array}{l}\text { Reddish gyttja with three fine bands of basaltic ash. LOI between } 4 \text { and } \\
14 \%\end{array}$ \\
\hline \multicolumn{3}{|l|}{ Lake Bruja } \\
\hline $700-683.5$ & Present & Clay. LOI between 2 and $32 \%$. \\
\hline 772-700 & 1800-Present & $\begin{array}{l}\text { Series of thick clayey-gyttja and basaltic ash layers with varied thickness. } \\
\text { LOI between } 1 \text { and } 22 \% \text {. }\end{array}$ \\
\hline 795-772 & $2200-1800$ & $\begin{array}{l}\text { Various layers of clayey-gyttja and narrow layers of basaltic ash. LOI } \\
\text { between } 1 \text { and } 14 \% \text {. }\end{array}$ \\
\hline 812-795 & $\sim 2200$ & Two thick bands of basaltic ash with an incursion of a clayey-gyttja layer. \\
\hline $835-812$ & $3300-2200$ & $\begin{array}{l}\text { Alternate laminations of clayey-gyttja, basaltic ash, and gyttja. LOI } \\
\text { between } 1 \text { and } 36 \%\end{array}$ \\
\hline $840-835$ & $3600-3300$ & Light clayey-gyttja and basaltic ash segment. \\
\hline
\end{tabular}


The sedimentation rate of both cores fluctuates between 0.1 to $0.8 \mathrm{~mm} \mathrm{yr}^{-1}$. In the last 100 years, Avutarda shows the fastest sedimentation rates $\left(2 \mathrm{~mm} \mathrm{yr}^{-1}\right)$, while the fastest sedimentation rates at Bruja (2 mm $\mathrm{yr}^{-1}$ ) occurred around 3500 cal. $\mathrm{yr}$ BP. The sediments from both lakes show alternations between gyttja and basaltic-ash layers throughout the record (Table 2, Figure 14). In addition, the core from Avutarda contains a thick pumiceous-ash segment between 253 and $236 \mathrm{~cm}$ depth. Tephra layers recorded in both cores $>1 \mathrm{~cm}$ thick consist entirely of volcanic material. Not organic or minerogenic material mixed with the volcanic glass is observed. It can therefore be assumed that inwash of allochthonous material into the lake during or following the volcanic eruptions must have been low. Consequently, tephra layers represent a particular volcanic event and their thickness gives an idea of the magnitude of the eruption. Although both sites are situated $15 \mathrm{~km}$ apart, the tephra layers in both cores could not be matched visually (Figure 14) 


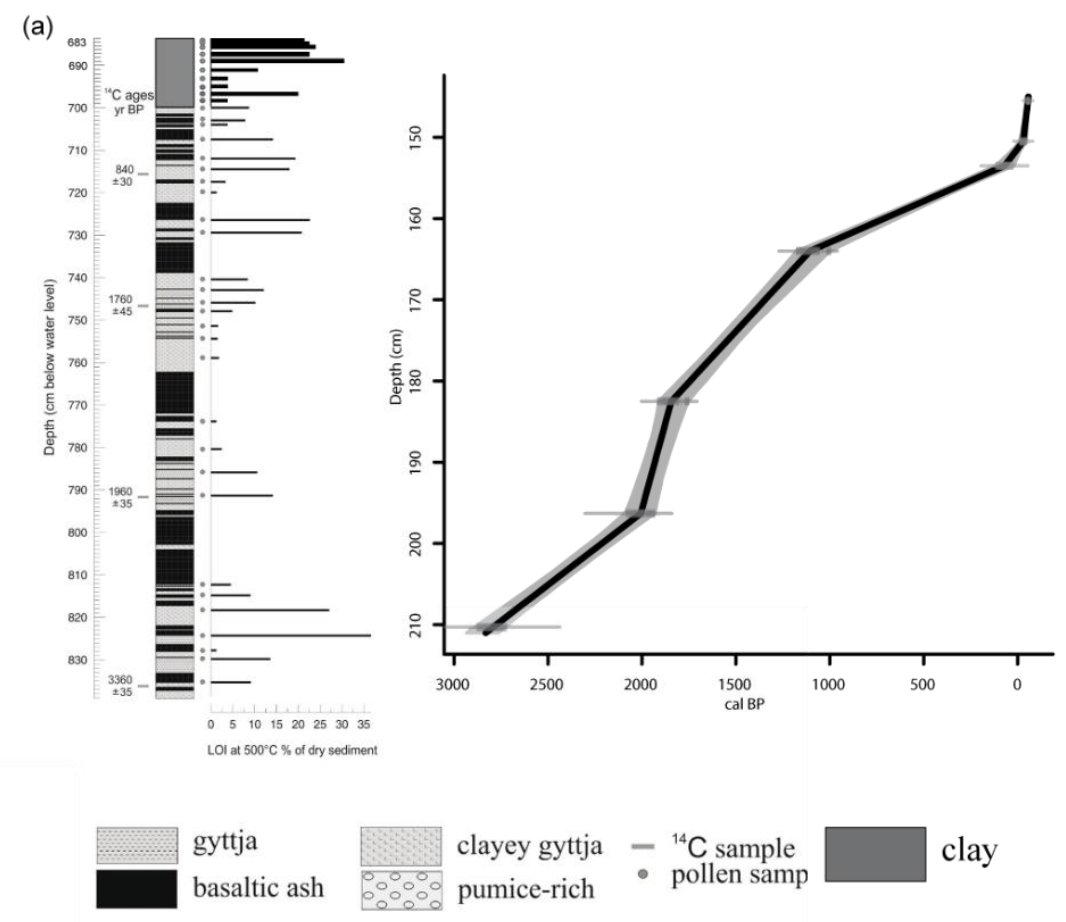

(b)

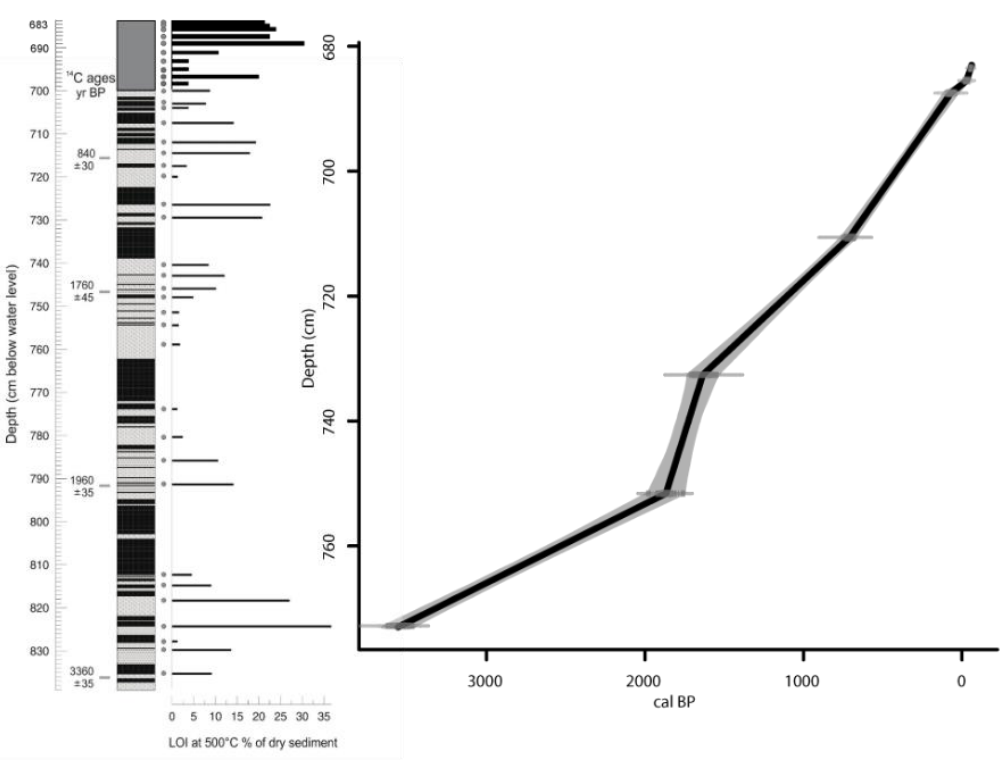

Figure 14. Lithology and age-depth model of (a) Avutarda, and (b) lithology, macrocharcoal (particles/cm²), and age-depth model of Bruja. Notice adjusted depth in Y axis in agedepth model. 


\subsubsection{Avutarda and Bruja pollen record and Fire History of Lake Bruja}

Changes in pollen composition were summarized for both Avutarda and Bruja in Table 3 and scarce pollen types (up to 3 pollen grains per sample) are presented in Table 4. The constraint cluster analysis indicated three distinct groups for both sites and the diagrams were subdivided into three zones accordingly (Figure 15). The different Nothofagus species occurring in the region can only be separated into two distinct pollen types: Nothofagus dombeyi-type corresponding to Nothofagus antarctica, Nothofagus pumilio and Nothofagus dombeyi and Nothofagus obliqua-type produced by Nothofagus alpina and Nothofagus obliqua. At both sites, pollen of Nothofagus obliqua-type is mostly attributed to Nothofagus alpina. This pollen type is large and heavy, with short distance pollen dispersal (<35 m, Marchelli et al., 2012), and therefore has a restricted pollen source area. Nothofagus alpina occurs today around Lake Bruja and ca. $250 \mathrm{~m}$ downslope on the western side of Lake Avutarda (1610 m a.s.l.), between ca. 800 and $1350 \mathrm{~m}$ a.s.l. These tree populations of Nothofagus alpina may have largely contributed to the total pollen of Nothofagus obliqua-type recorded at Avutarda, due to upslope pollen transport by the prevailing westerly winds. Pollen input of Nothofagus obliqua into the lake basins is of regional origin (sensu Prentice, 1985), and therefore contributing in a small proportion to the pollen records. The southern distribution limit of Nothofagus obliqua occurs ca. $5 \mathrm{~km}$ north/north-east of Lake Bruja and $20 \mathrm{~km}$ north of Lake Avutarda. In addition, both sites are above the modern altitudinal optimum of Nothofagus obliqua in the region, making it unlikely the tree occurred in the proximity of the lakes during the last 3000 years. Cupressaceae pollen is attributed largely to Austrocedrus chilensis, although individual grains may come from the rainforest taxa Fitzroya cupressoides or Pilgerodendron uviferum via longdistance transport.

The location of the lakes determines the type of pollen signal captured. Bruja, situated on the mountain slope at $1060 \mathrm{~m}$ a.s.l. within a dense forest, is documenting mainly changes in the local vegetation, reflected by the high percentage of Nothofagus dombeyi-type corresponding to the dominance of Nothofagus dombeyi occurring around the lake, Nothofagus pumilio above $1150 \mathrm{~m}$ a.s.l. and few individuals of Nothofagus antarctica growing at the lake shore as well as downslope in the valley. Lake Avutarda is located at the tree line (1610 $\mathrm{m}$ a.s.l.), where the persistent westerlies bring extra local components. Therefore, pollen from extra local origin is stronger represented including Podocarpus nubigenus, Saxegothaea conspicua, Weinmannia trichosperma, and Eucryphia/Caldcluvia. 
Table 3. Vegetation history of Avutarda and Bruja records.

\begin{tabular}{|c|c|c|c|}
\hline Zone & Age cal. yr BP & Pollen zone characteristics & Interpretations \\
\hline \multicolumn{4}{|c|}{ Avutarda } \\
\hline Avu-3 & 100-Present & $\begin{array}{l}\text { Presence of human landuse indicator taxa: Rumex acetosella, Plantago } \\
\text { lanceolata and Pinus (in that order of appearance); reduction in the percentage } \\
\text { of Poaceae, Ranunculus, Asteraceae subf. Asteroideae and Nothofagus dombeyi- } \\
\text { type. Palynological richness }=20-28 \text { taxa. }\end{array}$ & $\begin{array}{l}\text { Forest clearing and animal husbandry close to the } \\
\text { lake. }\end{array}$ \\
\hline Avu-2 & $1200-100$ & $\begin{array}{l}\text { Gradual increase in the percentage of Nothofagus obliqua-type }(2.7 \% \text {, peak } \\
\text { around } 500 \text { cal. yr BP), as well as an increase in the percentage of rainforest taxa, } \\
\text { and a decrease in Hydrangea and Misodendrum. Asteraceae subf. Asteroideae } \\
\text { remains high as the prior zone. Palynological richness }=14-26 \text { taxa. }\end{array}$ & $\begin{array}{l}\text { Increase of downslope population abundance of } \\
\text { Nothofagus alpina. }\end{array}$ \\
\hline Avu-1 & $2800-1200$ & $\begin{array}{l}\text { Decline of Nothofagus dombeyi-type and increase of Poaceae between } 2500 \text { and } \\
2000 \text { cal. yr BP. First encounter of Nothofagus obliqua-type pollen at } 2300 \text { cal. yr } \\
\text { BP. Asteraceae subf. Asteroideae shows its highest percentage ( } 3.7 \%) \text {. Epiphytic } \\
\text { taxa show a continuous presence ( } 1 \% \text { ). Ranunculus shows the maximum } \\
\text { percentage ( } 4.8 \%) \text {, followed by Gunnera ( } 2.6 \%) \text {. The end of this zone is } \\
\text { characterized by an increase of Nothofagus dombeyi-type and a decrease of } \\
\text { Poaceae percentage. Palynological richness = 16-27 taxa. }\end{array}$ & $\begin{array}{l}\text { Local and regional decrease of Nothofagus } \\
\text { pumilio. Expansion of herbs and grasses. }\end{array}$ \\
\hline \multicolumn{4}{|l|}{ Bruja } \\
\hline Bru-3 & 88-Present & $\begin{array}{l}\text { Appearance of Rumex acetosella, Plantago lanceolata and Pinus. Reduction in the } \\
\text { percentage of Nothofagus dombeyi-type with a slight increase of Poaceae } \\
\text { percentage. Palynological richness }=18-25 \text { taxa. }\end{array}$ & $\begin{array}{l}\text { Use of natural open areas for grazing. Short-scale } \\
\text { timber activities. }\end{array}$ \\
\hline Bru-2 & $1200-88$ & $\begin{array}{l}\text { Slight reduction in the percentage of Nothofagus dombeyi-type and } \\
\text { Cupressaceae and increase in the percentage of Nothofagus obliqua-type. Slight } \\
\text { decrease in the percentage of Misodendrum, Asteraceae subf. Asteroideae and } \\
\text { Poaceae. The end of this zone is marked by the appearance of the human } \\
\text { introduced taxa Rumex acetosella. Palynological richness }=10-17 \text { taxa. }\end{array}$ & $\begin{array}{l}\text { Closed forest. Reduction of the diversity of } \\
\text { herbaceous taxa. Local increase of Nothofagus } \\
\text { alpina populations occurring around the lake. }\end{array}$ \\
\hline Bru-1 & $3600-1200$ & $\begin{array}{l}\text { Frequent occurrence of Cupressaceae and Misodendrum. Rise of Nothofagus } \\
\text { obliqua-type at } 2200 \text { cal. yr BP (10.9\%). Presence of rain forest element } \\
\text { decreasing at } 2700 \mathrm{cal} \text {. yr BP. Continuous presence of Isoëtes (0.7\%) and its later } \\
\text { disappearance from the record at } 1600 \text { cal. yr BP. Abundance of Poaceae, } \\
\text { Asteraceae subf. Asteroideae and Chenopodiaceae. Presence of steppe elements } \\
\text { (e.g. Azara, Maytenus, Discaria) lower than } 7 \% \text {. Palynological richness }=12-23 \\
\text { taxa. }\end{array}$ & $\begin{array}{l}\text { Open forest. Codominance of Nothofagus and } \\
\text { grass. High diversity in the herbaceous stratum }\end{array}$ \\
\hline
\end{tabular}


Table 4. Rare pollen types (up to 3 pollen grains per sample) at Lakes Avutarda and Bruja (not shown in the pollen diagrams).

\begin{tabular}{|c|c|c|c|c|c|c|}
\hline & & Avutarda & & & Bruja & \\
\hline Age (cal. yr BP) & $0-100$ & $100-200$ & $1200-800$ & $0-88$ & $88-1200$ & $1200-3600$ \\
\hline Taxa/Pollen zones & Avu-3 & Avu-2 & Avu-1 & Bru-3 & Bru-2 & Bru-1 \\
\hline Araucaria araucana & & & & & $*$ & \\
\hline Alnus acuminata & & $* \quad * \quad *$ & $* *$ & & & \\
\hline Lomatia hirsuta & $*$ & $*$ & & $*$ & $*$ & \\
\hline Drimys winteri & & & $* \quad * *$ & & $*$ & \\
\hline Maytenus & $*$ & $* *$ & $* \quad * *$ & & & \\
\hline Embothrium coccineum & & $*$ & & & & \\
\hline Ribes & $*$ & & $*$ & & & \\
\hline Aster. subf. Cichorioideae & $* \quad * \quad *$ & & & $*$ & & \\
\hline Nassauvia & & & & & & $* *$ \\
\hline Quinchamalium & & & & & $*$ & \\
\hline Valeriana & & & & $*$ & $*$ & \\
\hline Viviania & & & & & $*$ & $*$ \\
\hline Ranunculus & & & & & $*$ & \\
\hline Berberis & & & $*$ & & & \\
\hline Azorella & & & & & & $*$ \\
\hline Armeria & & & $*$ & & & \\
\hline Verbenaceae & & & & & & $*$ \\
\hline Iridaceae & $*$ & & & & & \\
\hline Adesmia & & & $*$ & & & \\
\hline Rubiaceae & & $* \quad *$ & $*$ & & & \\
\hline Mulinum & $*$ & & & & & \\
\hline Polygonaceae & $*$ & & $* *$ & & & \\
\hline Escallonia & $* \quad *$ & $* \quad *$ & $*$ & $*$ & $*$ & $*$ \\
\hline Unknown & $* \quad *$ & $* \quad *$ & $*$ & $*$ & $*$ & $*$ \\
\hline Isoëtes & & $* *$ & & & & \\
\hline Hymenophyllum & & & $*$ & & & \\
\hline Polypodium feuillei & & & & & $*$ & \\
\hline Anthoceros/Phaoceros & & & & & & $*$ \\
\hline Litorella/Plantago & & & $*$ & & & \\
\hline
\end{tabular}

*Represents a pollen grain unit found per zone. 
The accumulation of macroscopic charcoal in the sediments of Bruja is low with an average of 0.65 particles $\mathrm{cm}^{-2} \mathrm{yr}^{-1}$. Most of the charcoal counted correspond to grass ( $>80 \%$ in all the samples counted). Nevertheless, distinct peaks are visible and the signal-to-noise index (SNI) of 4.6 indicates a consistently good separation of the signal from background noise (Kelly et al., 2011). Eleven fire episodes were detected during the last 3600 years. Fire frequency was high between 2000 and 1600 cal. yr BP and 1000 and 500 cal. yr BP with a maximum of four episodes/500 years during the former period.

High fire magnitude indicates large or intensive fires (Whitlock et al., 2006). In Bruja, these episodes took place between 2000 and 500 cal. yr BP. Highest peak magnitudes were registered between 1700 and 600 cal. yr BP. Fire-free intervals, with at least 400 years between fire events were observed along the record. Time between fire events was shorter between 2000 and $800 \mathrm{cal}$. yr BP, with an interval of 100 to 200 years.

\subsubsection{PCA and RDA}

For both records the PCA analyses show that the composition of samples was relatively stable through time with the first PCA-axis explaining only $23 \%$ and $17 \%$ of the variance for Avutarda and Bruja, respectively. The grouping obtained in the constrained cluster analysis was not reproduced by the PCA. In Avutarda the PCA only separates the samples from the youngest pollen zone, while no clear grouping of samples was obtained for Bruja. The first axis in the PCA for Avutarda separates the samples according to their proportion of Ranunculus, Caryophyllaceae and Poaceae versus Pinus and Rumex acetosella and Plantago lanceolata (Figure 16a). Therefore, it may be considered that the first component represents a land use gradient that increases from left to right. It is interesting to note that Poaceae are not associated with the human impact indicator taxa, suggesting that the area around Lake Avutarda was not intensively used for agrarian and pastoral activities. The second axis explaining $12 \%$ of the variance separated the samples according to the proportion of Nothofagus dombeyi-type versus Nothofagus obliqua-type. 
(a)
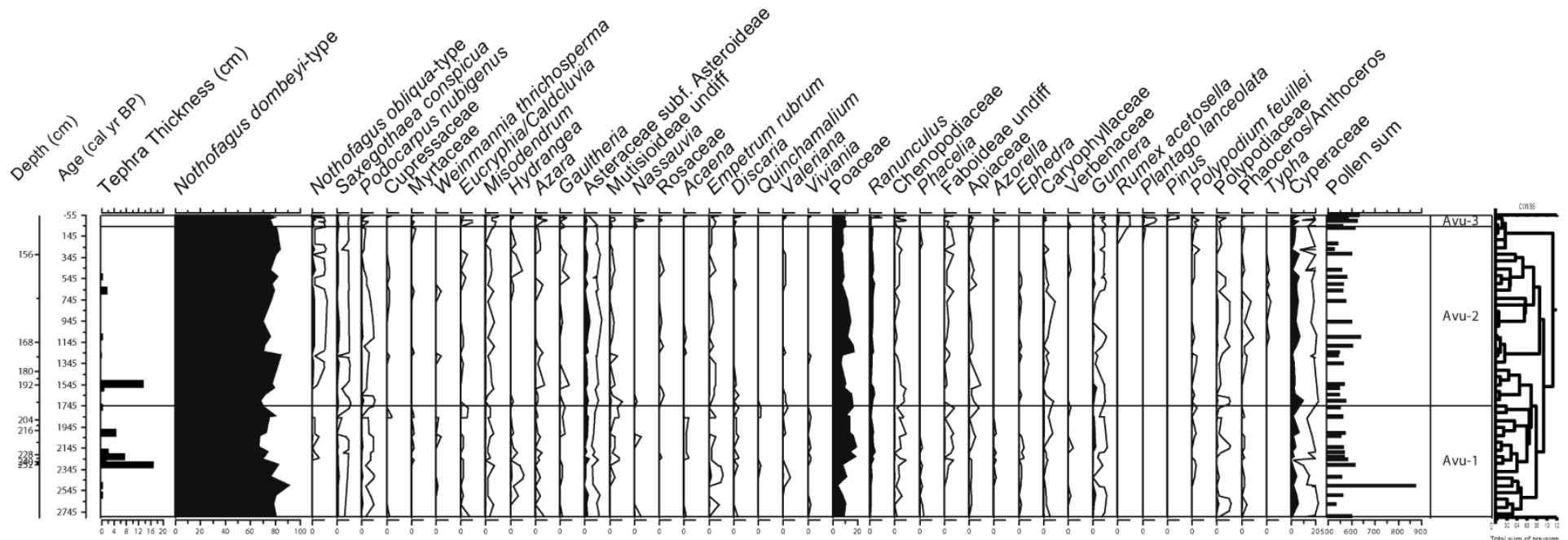

(b)
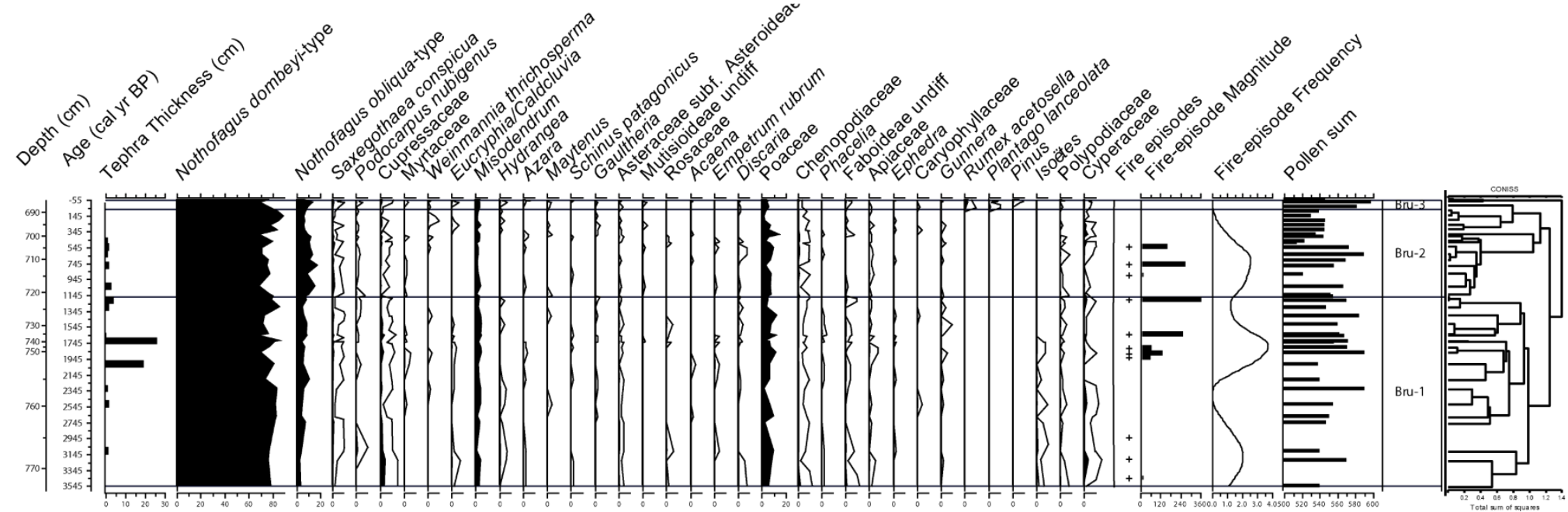

Figure 15. Percentage pollen diagram from (a) Avutarda record and percentage pollen diagram and macrocharcoal results from (b) Bruja, including pollen sums. Outline curve represent 10x exaggeration for minor taxa. 

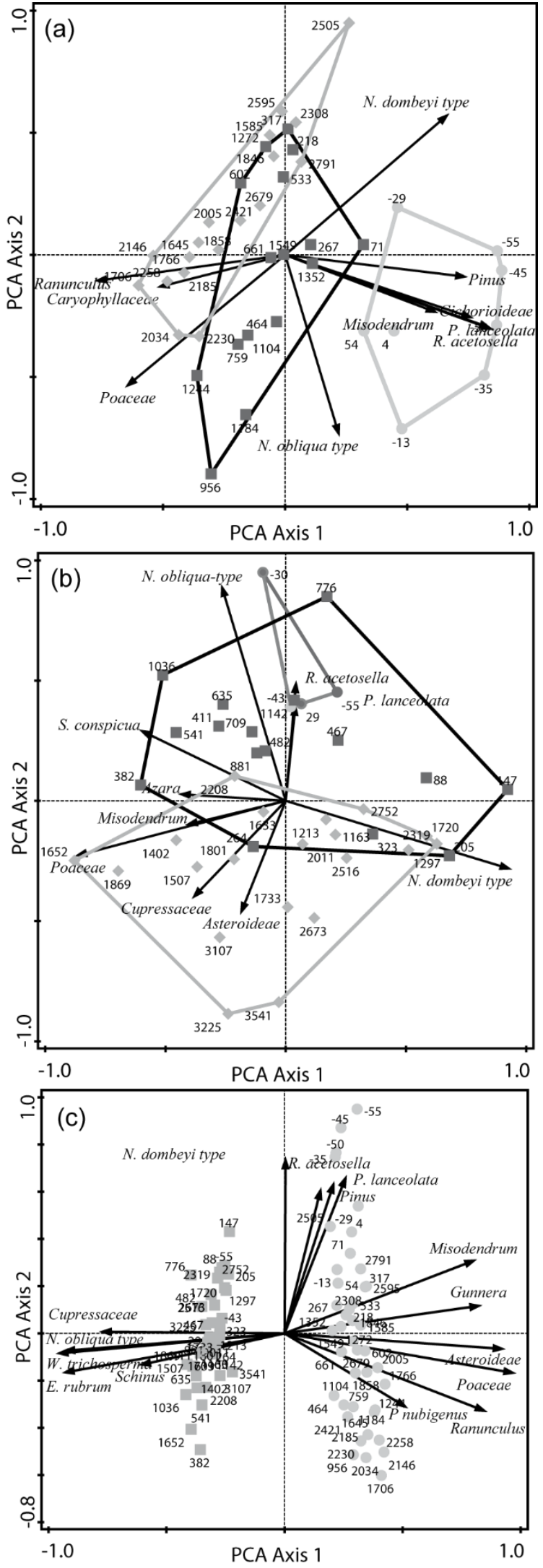

The first PCA axis in Bruja separated the samples according to their percentage of Poaceae and Misodendrum versus Nothofagus dombeyi-type. The second axis explained $16 \%$ of the variance and split the samples according to their proportion of Cupressaceae and Asteraceae subf. Asteroideae versus human indicator taxa (Figure 16b). The sample arrangement on the PCA shows two main vegetation phases through time. The first phase (lower two quadrants corresponding to 3600 and 1100 cal. yr BP), with samples characterized by steppe taxa; and a second phase (upper two quadrants corresponding to the last 1100 years) characterized by Nothofagus obliquatype.

Submitting both records to the same PCA analysis revealed a clear separation between both sites (Figure 16c) with the first axis explaining $68 \%$ of the variance. The first axis is representing the environmental gradient between the two sites, which is a combination of the altitudinal difference and the precipitation gradient.

Figure 16. Species/sample scores of the PCA of pollen percentage data of (a) Lake Avutarda and (b) Lake Bruja. Grouping by CONISS shown by different symbols in the PCA: rhombus= zone 1 ; squares= zone 2 ; and circles $=$ zone 3 . (c) Combined ordination of Lake Bruja (squares) and Lake Avutarda (circles). 
On the right side, the samples from Lake Avutarda were characterized by Asteraceae subf. Asteroideae, Poaceae and Ranunculus, which is in accord with the high elevation position of this lake, at the treeline of Nothofagus pumilio. On the other hand, samples from Lake Bruja (left side, squares) were characterized mainly by Nothfagus obliqua-type and some rain forest elements such as Weinmannia trichosperma and Drimys winteri (not shown here). The second axis explained $5 \%$ of the variance, and separates the samples according to the presence of human indicator taxa such as Rumex acetosella, Plantago lanceolata and Pinus. These species are present in the youngest samples (on top) and they have a negative correlation with Poaceae and a positive correlation with Nothofagus dombeyi-type. The taxa arrows belonging to Avutarda quadrant indicate the extra local input represented in this site, which also includes Nothofagus dombeyi-type.

We applied RDA analysis to the pollen data from both sites to investigate whether the deposition of tephra layers had any effect on the pollen composition of the next younger samples (Table 5, Figure 17) but found no significant effect (Lake Bruja: explained variation of the distance to the tephra 2.0\%; and tephra thickness $2.1 \%$ ). However, in individual cases we visually observed changes in pollen percentages and or a reduction in taxonomic richness in both records. The samples following the two thickest tephra layers in Bruja contain higher proportions of Poaceae pollen (11\%) with a decrease in Nothofagus dombeyi pollen, while the sample with an even higher Poaceae proportion (14\%) is not following a tephra layer. For Bruja we also tested whether changes in fire frequency and magnitude explain changes in pollen composition, but also here found no significant influence of the fire regime on the vegetation (explained variation $4.4 \%$ and $3.4 \%$ respectively). 

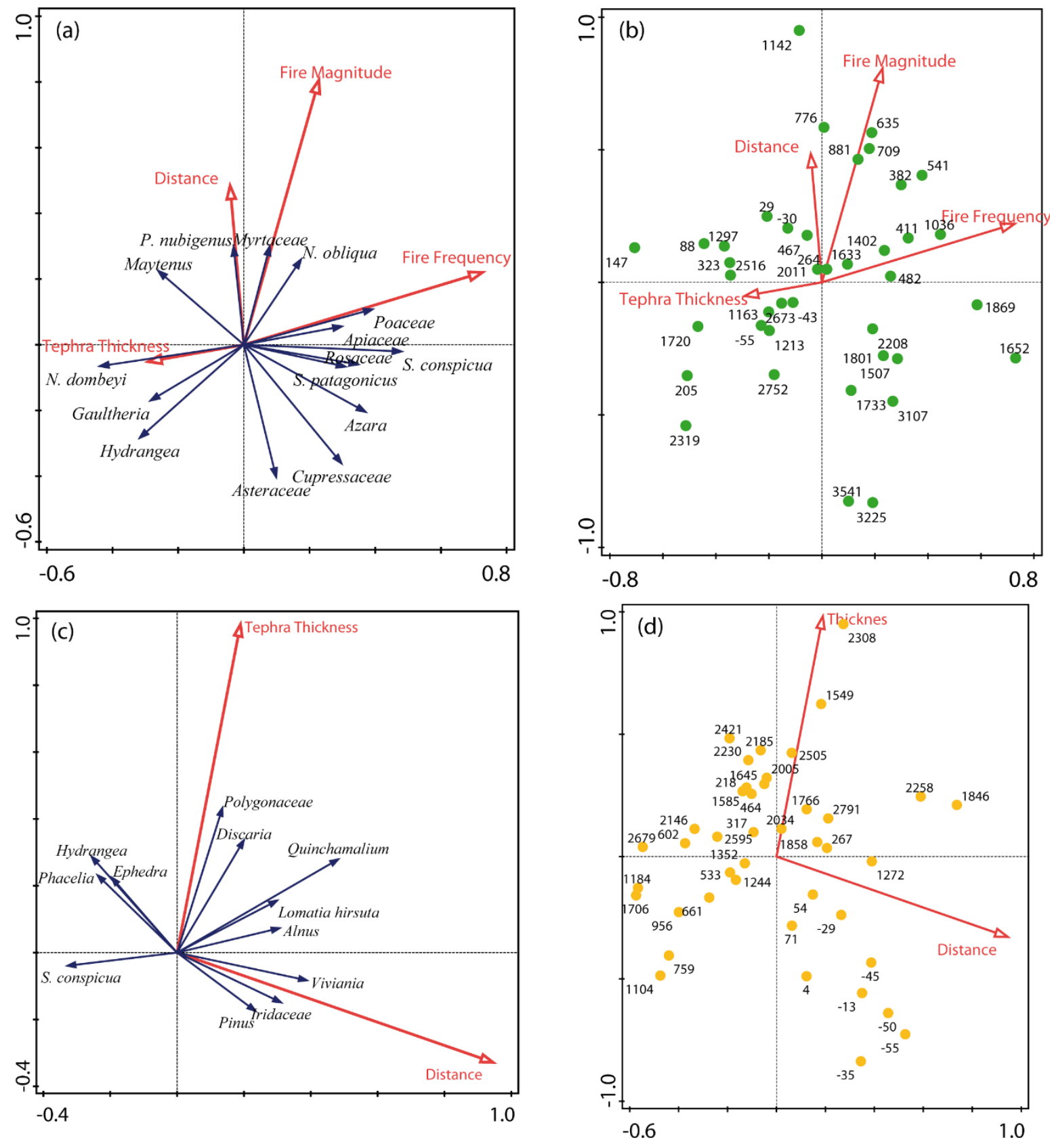

Figure 17. Redundancy analysis (RDA) biplot of selected species and samples, and explanatory variables for (a, b) Lake Bruja and (c, d) Lake Avutarda. 
Table 5. RDA results performed on pollen percentages of Lakes Avutarda and Bruja.

\begin{tabular}{|c|c|c|c|c|}
\hline $\begin{array}{l}\text { Explanatory } \\
\text { variables }\end{array}$ & $\begin{array}{l}\text { Explained } \\
\text { variation \% }\end{array}$ & Pseudo-F & $p$ & $p$ (adj) \\
\hline \multicolumn{5}{|l|}{ Lake Avutarda } \\
\hline $\begin{array}{l}\text { Distance to the } \\
\text { tephra }\end{array}$ & 3.4 & 1.4 & 0.096 & 0.192 \\
\hline $\begin{array}{l}\text { Tephra } \\
\text { thickness }\end{array}$ & 2.0 & 0.8 & 0.704 & 1. \\
\hline \multicolumn{5}{|l|}{ Lake Bruja } \\
\hline Fire frequency & 4.4 & 1.7 & 0.474 & 1 \\
\hline Fire magnitude & 3.4 & 1.3 & 0.322 & 1 \\
\hline $\begin{array}{l}\text { Tephra } \\
\text { thickness }\end{array}$ & 2.1 & 0.8 & 0.658 & 1 \\
\hline $\begin{array}{l}\text { Distance to the } \\
\text { tephra }\end{array}$ & 2.0 & 0.8 & 0.832 & 1 \\
\hline
\end{tabular}

\subsection{Discussion}

\subsubsection{Vegetation history and population increase of Nothofagus alpina}

The most pronounced result of this investigation is that the vegetation was stable around Avutarda and Bruja over the last 3600 years, regardless of tephra depositions of up to $20 \mathrm{~cm}$, fire activity, and presumed increase in ENSO variability (Flantua et al., 2016; Moy et al., 2002). The increase in the percentage of Nothofagus obliqua-type, attributed here mostly to Nothofagus alpina, appear as one of the most noticeable changes in our records, however, this change is gradual and most likely not triggered by a single disturbance event, such as a large scale fire. Documentation of the vegetation history of Nothofagus alpina in palynological records is limited, especially on the Argentinean side of the Andes, where its distribution is restricted to valleys between $39^{\circ}$ to $40^{\circ} \mathrm{S}$ (see Sabatier et al., 2011), and most of the investigations have so far focused on sites further south or north, capturing scarcely its presence. Thus, our records provide a first account of the Late Holocene history of Nothofagua alpina since the lakes are located close to the main population of this species in the Lake Lácar basin in the Lanín National Park. 
Lake Bruja is surrounded by a dense forest of Nothofagus alpina and located $6 \mathrm{~km}$ south of Lake Lácar, where the largest populations of Nothofagus alpina as well as Nothofagus obliqua occur today (Figure 13c). The uppermost surface sample from Lake Bruja comprises 9.1\% of Nothofagus obliquatype pollen that increased from 3.3\% at the beginning of the record around 3600 years ago (Figure 15b). Lake Avutarda, collects $1 \%$ of Nothofagus obliqua-type pollen in the modern samples, with the continues pollen curve starting around 1500 cal. yr BP (Figure 15a). At Avutarda, the closest Nothofagus alpina population occur $250 \mathrm{~m}$ downslope (Figure 13c), while the closest Nothofagus obliqua population is found at $20 \mathrm{~km}$ northwest, around Lake Lácar.

This Late Holocene increase of Nothofagus obliqua-type finds a parallel in the Late Holocene expansion of Austrocedrus chilensis to the south of the study region. Several pollen diagrams from the forest-steppe ecotone between $41^{\circ}$ to $43^{\circ} \mathrm{S}$ document the expansion of Austrocedrus chilensis between 5000 and 2000 years ago (Iglesias et al., 2014). Austrocedrus chilensis is also abundant on the eastern end of Lake Lácar, while its pollen type is scarcely represented at Avutarda and declines at Bruja. In this case Cupressaceae pollen decline from an initial $3 \%$ to $1 \%$ coinciding with the increase of the Nothofagus obliqua-type pollen. This may suggest either a decrease of Austrocedrus chilensis individuals or an override-effect of the Cupressaceae pollen signal, due to the large amount of pollen production of the Nothofagus species (Fontana and Bennett, 2012) in comparison with Austrocedrus chilensis, which has a locally restricted pollen dispersal (Markgraf et al., 1981).

Austrocedrus chilensis is a drought-resistant taxon. However, its growth and distribution are mainly depending on moisture availability and precipitation, especially during the growing season (Kitzberger et al., 2000; Villalba and Veblen, 1997). Where the expansion of Austrocedrus chilensis occurs at sites towards the steppe (e.g. Lago Mosquito, Iglesias et al., 2011) it is interpreted as a reaction to a more humid climate while other climatic shifts or changes in the fire regime may have triggered the expansion elsewhere (Iglesias et al., 2014). However, the general trend in Late Holocene climate change in Northern Patagonia is towards more humid conditions (Lamy et al., 2001; Mancini et al., 2008). Causes for increased humidity during the Late Holocene may be the northward shift and or enhanced strength of the Southern Westerlies (Fletcher and Moreno, 2011; Moreno et al., 2010). At the same time the climate may also have become more variable with enhanced ENSO activity (Flantua et al., 2016; Montecinos and Aceituno, 2003), possibly leading to alternations of drought and wet years perhaps providing an opportunity for a gradual replacement of tree taxa though gap dynamics. Nothofagus alpina and Nothofagus obliqua occur in areas with 
winter precipitation and dry summers (Alberdi, 1987; Conticello et al., 1996; Donoso, 2013; Ramirez et al., 1997), while it is most likely their requirement for growing season warmth that limits their distribution in the east and south. Both trees would have benefitted from increased Late Holocene moisture availability.

Although our records do not provide a strong evidence related to changes in precipitation seasonality and ENSO variability, the population increase of Nothofagus alpina during the Late Holocene is consisted with interpretations of Late Holocene climate change for southern South America (Lamy et al., 2001; Stine and Stine, 1990).

\subsubsection{Disturbance history}

The lithologies of the cores from Avutarda and Bruja document a constant and significant volcanic activity in the region (Table 2, Figure 14a and b) and one would expect that the vegetation should respond to this disturbance agent. High volcanic activity is reported for the entire Holocene in southern South America (Fontijn et al., 2014; Naranjo and Moreno, 1991; Naranjo et al., 1993). Due to the westerlies, most of the ash falls on the eastern flank of the Andes Cordillera (Gaitán et al., 2011), affecting flora and fauna (Berenstecher et al., 2017).

For the last 3600 cal. yr BP captured in our records frequent volcanic activity occurred between 2300 cal. yr BP to 900 cal. yr BP, which coincide with minor changes in the percentage and concentration of Nothofagus dombeyi-type. Simi et al. (2017) report volcanic activity in two records in the Aysén region in southwest Chile, showing a minimal variation in arboreal pollen, similar to our records. In both cases, these slight changes in pollen percentage are reflecting the persistence of the forest despite the constant disturbance processes related to volcanic activity. Montiel et al. (2016) analysed the impact of tephra layers on populations of Nothofagus species after the eruption of the Puyehue-Cordón Caulle Volcanic complex in June 2011. According to their results, based on treestands and tree-ring analysis, they concluded that some trees died because of the mechanic damage caused by the massive ash fall $(>50 \mathrm{~cm})$, and surviving trees showed no ring development after the event. Nevertheless, they observed a considerable regeneration of Nothofagus seedlings but they could not show that this effect is directly related to the ash deposition. Since the thickest tephra layer in our records is $30 \mathrm{~cm}$, mechanic damage on the branches of Nothofagus due to the ash fall may not have occurred here. Nevertheless, we cannot reject the possibility that ash deposition could have caused some impact on the foliage, as is demonstrated in some post-volcanic event studies (Chaneton et al., 2014) and therefore, it could affect pollen productivity. The finding that thick 
tephra deposits did not show significant effects on the vegetation may account for specific strategies of some plant species to reduce a negative effect. For example, the development of adventitious roots in Nothofagus antarctica (Veblen et al., 1977). González et al. (2014) reported the establishment of Nothofagus pumilio sprouts one year after the Hudson volcano eruption, as well as the surviving of understory species. Likely these strategies are the consequence of an adaptative response to the systematic occurrence of this disturbance process (Veblen et al., 1977).

Another example of the effect on the vegetation composition after a volcanic eruption indicates that the chemical composition of the ash plays an important role for the establishment or the decline of some taxa. An increase in soil acidification due to ash deposition may facilitate the establishment of new species or hindering the recovery of pre-existing species (Fontana and Bennett, 2012). In our case, the short-term effect of ash deposition likely is not noticeable due to the constant influx of Nothofagus pollen into the lake.

The RDA results show that the effect of tephra deposition on the vegetation in both records is detectable, but not statistically significant as to have caused repeatedly a noticeable change in vegetation composition ( $p$ value $>0.05$ and explained variation $<4.5 \%$ in all the variables tested; Table 5, Figure 17). The slight decline in Nothofagus and the increase in shrubs and herbs after one of the tephra layers may have been caused by volcanic ash deposition. In addition, during periods of large ash deposition, fire events started to be frequent and possibly, these two local disturbance agents may have caused together the observed changes on the vegetation after single events. Moreover, when disturbance processes (fire and ash fall) and climate act simultaneously it is quite difficult to identify which factor caused the observed changes on the vegetation (De Porras et al., 2014). In the analysed records, the response in terms of increase or decrease in percentage and concentration (not shown) of individual taxa seems random. For example, at Avutarda percentage values of Nothofagus dombeyi-type pollen decrease from $83 \%$ to $70 \%$ after $18 \mathrm{~cm}$ of tephra. However, in the same record, the same taxon increases from $78 \%$ to $83 \%$ after $17 \mathrm{~cm}$ of tephra. In the case of Poaceae percentage, this random effect of ash is also observed. From $8 \%$ to $15 \%$ after $18 \mathrm{~cm}$ of tephra deposition and later, after $17 \mathrm{~cm}$ of tephra the percentage of Poaceae decrease from $10 \%$ to $7 \%$. Nevertheless, studies in Argentina as well in Chile report the importance of major disturbance processes in the development and dynamics of Nothofagus forests and in some cases, the forest as well as the understory seem to be resistant to the disturbance events (González et al., 2014). 
Several studies have assessed the impact of tephra deposition from different perspectives: treegrowth (Magnin et al., 2017), soil properties (Cremona et al., 2011; Gonzalez et al., 2015), fauna changes (Berenstecher et al., 2017; Lallement et al., 2014), leaf-litter decomposition (Chaneton et al., 2014; Piazza et al., 2018), among others. However, all these investigations have evaluated the impact of ash deposition at a short time scale, and potential long-term effects or the lack therefore are not clear. Based on our data it is difficult to disentangle the several factors that are acting at the same time, like fire, ash deposition, and climate. Moreover, one or more of these factors could strengthen or weaken the individual effect they have on the vegetation structure. Even in this situation, the vegetation reflected in both pollen diagram seems to be stable.

Fire plays an important role in North Patagonia, and its effect on the vegetation composition has been extensively studied (Dudinsky and Ghermandi, 2013; Kitzberger et al., 1997; Kitzberger and Veblen, 1999; Mermoz et al., 2005; Veblen et al., 1999; Whitlock et al., 2006, among others). Palynological and macro charcoal analysis in North Patagonia show that fire activity during the Late Holocene is associated with the strengthening of ENSO frequency/intensity, especially after 3000 cal. yr BP (Iglesias and Whitlock, 2014). Assessing the influence of fire events on the vegetation around Bruja, it was possible to identify eight fire episodes between 3500 and 1100 cal. yr BP, among which just five represent large or intensive fires and fire frequency increased between 2100 and 1100 cal. yr BP. Three fire episodes, with a frequency of 1-2 fires every 200 years were identified for the second zone (Bru-2; 1100-100 cal. yr BP). We expected a correlation between fire and Poaceae since most of the charcoal counted comes from grass. However, the influence of fire frequency on Poaceae percentages is only strong in one sample (Figure 17). The RDA results indicate a nonsignificant influence of fire frequency and fire magnitude on the vegetation composition. Overall, the explanatory variables tested in this work (fire frequency, fire magnitude, tephra thickness and distance to the preceding tephra) account for $13.7 \%$ of the variation. However, since pollen sampling was carried out contiguously only before and after major tephra layers, it is possible that variation on the percentage of some taxa due to fire were not detected in other sections of the core. Despite this, it is possible to suggest that the local fire signal captured by Lake Bruja corresponds to surface-fires, at low magnitude and possibly promoted by lightning. The source of the charcoal found in Bruja could come either from the Chusquea bamboo understory around Lake Bruja or the open grassland patches in the valley northeast of the lake. Nowadays farmers use this place for cattle and low-scale timber extraction. 


\subsubsection{Human impact}

Northern Patagonia has been under the influence of human activities since before the arrival of European settlers (Veblen and Lorenz, 1988), changing the vegetation and adding to the natural disturbance regimes. However, it is difficult to find evidence of these early land-use activities in pollen diagrams. The pollen diagram from Lake Bruja and Avutarda show the presence of pollen from the introduced plants Rumex acetosella, Plantago lanceolata and Pinus in their topmost samples. Based on the abundance of these pollen types, the area close to Lake Avutarda was more intensively used by European settlers than the area surrounding Lake Bruja. Today, Pinus plantations and a few farms are located $3 \mathrm{~km}$ north-west of Lake Avutarda.

The presence of Rumex acetosella and Plantago lanceolata in pollen records from southern South America has been used as an indicator for livestock grazing (Iglesias et al., 2016). A common pattern related to the arrival of European settlers is a decline in tree pollen with an increase in grass, due to forest clearance for pastureland (Fletcher and Moreno, 2012; Mancini et al., 2005; Szeicz et al., 1998). Our results do not show an increase in Poaceae pollen at the time of the rise in Rumex acetosella and Plantago lanceolata. The PCA for Avutarda and Bruja (Figure 16a and b) shows a negative correlation between the Poaceae vector and human indicators taxa. At the time of grazing activities, Poaceae percentages are stable or decreased, indicating that the area likely was not suitable for pasture.

The pollen diagram from Bruja shows a decline in the percentage of Nothofagus obliqua-type, immediately before the appearance of the human indicator pollen type. The age model in this section is not well constrained, however, it may be that the first European settlers around Lake Lácar area conducted selective-timber activities for house-building with a preference for Nothofagus alpina, due to its high wood-quality (Azpilicueta and Marchelli, 2016). Lanín National Park was created in 1937 (Administración de Parques Nacionales, 2012) and protective measures were established, and timber extraction was controlled, but initially continued at low rate. The result of this measure may be observed in the pollen diagram from Bruja where percentages of Nothofagus obliqua-type increase in the last 50 years, potentially indicating the effectiveness of those measures. Human-set fire in north Patagonia have been widely documented, based on reports written by eyewitness that indigenous people used fire for hunting (Veblen et al., 1999; Veblen et al., 2003). Thus, anthropogenic fires are not only related to European settlers. Fire frequency in the Bruja record declined in the last 500 cal. yr BP and fire activity is practically null towards current times, 
probably due to the measures adopted by the authorities in charge of the National Park. In the light of these results, it is possible to speculate that neither indigenous people nor European settlers have promoted significant changes on the vegetation composition close to Lake Bruja, as it is evidenced by our results. Moreover, our fire record during the last decades suggests effective fire suppression activities in the region.

\subsection{Conclusions}

During the Late Holocene, the local vegetation around both Avutarda and Bruja lakes shows minimal changes, indicating the stability of the vegetation during the last 3600 years at $40^{\circ} \mathrm{S}$. Even though we documented fire and volcanic activity in the region, we do not find evidence of large-scale vegetation reactions to these disturbances. The population increase of Nothofagus alpina was the most important change in vegetation composition during the last three millennia. Here, our records offer a first account of the vegetation history of this southern beech species. We speculate that the increase in effective moisture suggested in other investigations for the expansion of Austrocedrus chilensis in the region also determined the development of Nothofagus alpina. Human impact in the last century was detected by the presence of introduced taxa. However, the detected land-use change has not caused a significant impact on the vegetation composition in the region, accounting for the effectiveness of the measures carried out by the authorities of the National Park.

\section{Acknowledgements}

The success of the field campaign would not have been possible without the support of the following persons: Helmut Fisher, Diego Metz, Lucas Fonso and Tomás (the coring team); Mónica Rodriguez, Sandra Aliscioni and Viviana Oliva (the plant collection group); local guides and park rangers of the Lanín National Park, in particular Laura Chazarreta and Salvador Vellido (for anything that we needed). Maria Papadopoulou and Michael Burstert assisted in the laboratory. We are extremely grateful to all of them for their invaluable help. David Henríquez is acknowledged for drawing the map in Figure 1, and Ana M. Abarzúa for her valuable help in pollen identification.

\section{Funding}

This research was supported by a scholarship to VA through CONICYT BECAS CHILE, 2015 ( $\left.n^{\circ} 72160354\right)$ and the German Research Foundation, FO 801/3-1 and GI 732/9-1. 


\section{Declaration}

The lacustrine sediment core obtained from the lakes Avutarda and Bruja were obtained under the approval of the authorities of Argentinean National Parks, with authorization DRP $n^{\circ} 687$ and through ATM n IF-2020-09669947-APN-DTC\#APNAC

\section{References}

Administración de Parques Nacionales (2012) Plan de Gestión Parque Nacional Lanín. Tomo I: caracterización y diagnóstico.

Alberdi M (1987) Ecofisiologia de especies chilenas del género Nothofagus. Bosque 8(2):77-84.

Azpilicueta MM and Marchelli P (2016) Zonas Genéticas de Raulí y Roble Pellín en Argentina: Herramientas para la conservación y el manejo de la diversidad genética. Ediciones INTA.

Baker WL (1995) Longterm response of disturbance landscapes to human intervention and global change. Landscape Ecology 10(3):143-159.

Bennett KD and Willis KJ (2001) Pollen. In: Smoll JP, Birks HJB, and Last WM (eds) Tracking Environmental Change Using Lake Sediment. Volume 3 Terrestrial, Algal and Siliceous Indicators. Kluwer Academic Publishers 5-32.

Berenstecher P, Gangi D, González-Arzac A et al. (2017) Litter microbial and soil faunal communities stimulated in the wake of a volcanic eruption in a semi-arid woodland in Patagonia, Argentina. Functional Ecology 31:245-259.

Birks HJB and Line JM (1992) The use of rarefaction analysis for estimating palynological richness from Quaternary pollen-analytical data. The Holocene 2:1-10.

Blaauw M (2010) Methods and code for 'classical' age-modelling of radiocarbon sequences. Quaternary Geochronology 5:512-518.

Chaneton EJ, Mazía N, Garibaldi LA et al. (2014) Impact of volcanic ash deposition on foliar productivity and insect herbivory in northern Patagonia deciduous forests. Ecología Austral 24:5163.

Cremona MV, Ferrari J, López S (2011) Las cenizas volcánicas y los suelos de la región. Instituto Nacional de Tecnología Agropecuaria. Laboratorio de suelos y aguas. Presencia Edición Especial 811.

Conticello L, Grandullo R, Bustamante A et al. (1996) Fitosociologia de los bosques caducifolios del norte del Departamento Lácar y sur de Huiliches de la provincia de Neuquén (Argentina). Bosque 17(2):27-43.

Cuevas JG (2000) Tree recruitment at the Nothofagus pumilio alpine timberline in Tierra del Fuego, Chile. Journal of Ecology 88:840-855. 
Dale VH, Joyce LA, MacNulty S et al. (2001) Climate Change and Forest Disturbances. BioScience 51(9):723-734.

De Porras ME, Maldonado A, Quintana FA et al. (2014) Environmental and climatic changes in central Chilean Patagonia since the Late Glacial (Mallín El Embudo, $44^{\circ} \mathrm{S}$ ). Climate of the Past 10:10631078.

Dezzotti A and Sancholuz L (1991) Los bosques de Austrocedrus chilensis en Argentina: ubicación, estructura, y crecimiento. Bosque 12(2):43-52.

Donoso C (2013) Las especies arbóreas de los bosques templados de Chile y Argentina. Autoecología. Valdivia, Chile.

Donoso C, Morales J, Romero M (1990) Hibridación natural entre roble (Nothofagus obliqua) (Mirb) Oerst. y Raulí (N. alpina (Poepp. \& Endl.) Oerst, en bosques del sur de Chile. Revista Chilena de Historia Natural 63:49-60.

Dudinzky N and Ghermandy L (2013) Fire as a stimulant of shrub recruitment in northwestern Patagonian (Argentina) grasslands. Ecological Research 28:981-990.

Fernández-Long ME and Müller GV (2006) Annual and monthly trends in frost days in the wet Pampa. In: Proceedings of 8 ICSHMO, Foz do Iguaçu, Brazil, April 24-28. INPE, pp 249-253.

Flantua SGA, Hooghiemstra H, Vuille $M$ et al. (2016) Climate variability and human impact in South America during the last 2000 years: synthesis and perspectives from pollen records. Climate of the Past 12:483-523.

Fletcher MS and Moreno PI (2012) Vegetation and fire regime changes in the Andean region of southern Chile $\left(38^{\circ} \mathrm{S}\right)$ covaried with centennial-scale climate anomalies in the tropical Pacific over the last 1500 years. Quaternary Science Reviews 46:46-56.

Fletcher MS and Moreno PI (2011) Zonally symmetric changes in the strength and position of the Southern Westerlies drove atmospheric CO2 variations over the past 14 k.y. Geology 39(5):419-422.

Fontana SL and Bennett K (2012) Postglacial vegetation dynamics of western Tierra del Fuego. The Holocene 22(11):1337-1350.

Fontijn K, Lachowycz SM, Rawson H et al. (2014) Late Quaternary tephrostratigraphy of southern Chile and Argentina. Quaternary Science Review 89:70-84.

Gaitán JJ, Ayesa JA, Umaña F et al. (2011) Cartografía del área afectada por cenizas volcánicas en las provincias de Río Negro y Neuquén. Instituto Nacional de Tecnología Agropecuaria.

Garreaud R, López P, Minvielle M et al. (2013) Large-Scale Control on the Patagonian Climate. Journal of Climate 26:215-230.

Garreaud RD (2009) The Andes climate and weather. Advances in Geoscience 22:3-11. 
González R, Dec D, Valle S et al. (2015) Efecto de cenizas volcánicas del Cordón Caulle sobre parámetros de calidad física en suelos agrícolas del sur de Chile. Agro sur 43:53-63.

Gonzalez ME, Amoroso M, Lara A et al. (2014) Ecología de disturbios y su influencia en los bosques templados de Chile y Argentina. In: Donoso C, Gonzalez ME, Lara A (eds) Ecologia forestal: bases para el manejo sustentable y Conservación de los Bosques Nativos de Chile. Valdivia: Ediciones UACh, pp. 411-502.

Grimm E (1993) TILIA 2.0. Springfield: Illinois State University.

Heiri O, Lotter A, Lemcke G (2001) Loss on ignition as a method for estimating organic and carbonate content in sediments: reproducibility and comparability of results. Journal of Paleolimnology 25:101-110.

Heusser CJ (1983) Quaternary Pollen Record from Laguna de Tagua Tagua, Chile. Science 219:14291432.

Heusser CJ (1971) Pollen and Spores of Chile. Arizona: University of Arizona Press.

Higuera PE, Brubaker LB, Anderson PM et al. (2009) Vegetation mediated the impacts of postglacial climatic change on fire regimes in the south-central Brooks Range, Alaska. Ecological Monographs 79(2):201-219.

Iglesias V, Quintana F, Nanavati W et al. (2016) Interpreting modern and fossil pollen data along a steep environmental gradient in northern Patagonia. The Holocene 27(7):1008-1018. DOI: 10.1177/0959683616678467.

Iglesias V and Whitlock C (2014) Fire responses to postglacial climate change and human impact in northern Patagonia $\left(41^{\circ}-43^{\circ} \mathrm{S}\right)$. Proceedings of the National Academy of Science 111(51):55455554.

Iglesias V, Whitlock C, Markgraf V et al. (2014) Postglacial history of the Patagonian forest/steppe ecotone $\left(41^{\circ}-43^{\circ} \mathrm{S}\right)$. Quaternary Science Review 94:120-135.

Iglesias V, Whitlock C, Bianchi MM et al. (2011) Holocene climate variability and environmental history at the Patagonian forest/steppe ecotone: Lago Mosquito (42²9'37.89'S, $\left.71^{\circ} 24^{\prime} 14.57^{\prime \prime} \mathrm{W}\right)$ and Laguna del Cóndor (42²0'47.22"S, 71¹7'07.62"W) The Holocene 22:1297-1307.

Jolly WM, Cochrane MA, Freeborn PH et al. (2015) Climate-induced variations in global wildfire danger from 1979 to 2013. Nature Communications 6:7537 DOI: 10.1038/ncomms8537.

Juggins S (2003) C2 User Guide. Software for Ecological and Palaeoecological Data Analysis and Visualisation. University of Newcastle.

Kelly RF, Higuera PF, Barrett CM et al. (2011) A signal-to-noise index to quantify the potential for peak detection in sediment-charcoal records. Quaternary Research 75:11-17.

Kitzberger T (2012) Ecotones as Complex Arenas of Disturbance, Climate, and Human Impacts: The Trans-Andean Forest-Steppe Ecotone of Northern Patagonia. In: Ecotones between Forest and 
Grassland. R.W. Myster (ed.) New York. Springer Science+Bussiness Media, pp 59-88. DOI 10.1007/978-1-4614-3797-0_3.

Kitzberger T, Steinaker DF, Veblen TT (2000) Effects of climatic variability on facilitation of tree establishment in northern Patagonia. Ecology 81(7):1941-1924.

Kitzberger T and Veblen TT (1999) Fire-induced changes in northern Patagonian landscapes. Landscape Ecology 14:1-15.

Kitzberger T, Veblen TT, Villalba $R$ (1997) Climatic influences on fire regimes along a rain forest-to xeric woodland gradient in northern Patagonia, Argentina. Journal of Biogeography 24:35-47.

Lallement ME, Juárez SM, Macchi PJ, Vigliano PH (2014) Puyehue Cordón-Caulle: post-eruption analysis of changes in stream benthic fauna of Patagonia. Ecología Austral 24:64-74.

Lamy F, Hebbeln D, Röhl U et al. (2001) Holocene rainfall variability in southern Chile: a marine record of latitudinal shift of the Southern Westerlies. Earth and Planetary Science Letters 185:362382.

Magnin A, Villalba R, Torres CD, et al. (2017) Effect of volcanic ash deposition on length and radial growths of a deciduous montane tree (Nothofagus pumilio). Austral Ecology 42:102-112.

Mancini MV, Prieto AR, Paez MM et al. (2008) Late Quaternary Vegetation and Climate of Patagonia. Developments in Quaternary Sciences 11:351-367.

Mancini MV, Paez MM, Prieto AR et al. (2005) Mid-Holocene climatic variability reconstruction from pollen records ( $32^{\circ}-52^{\circ} \mathrm{S}$, Argentina). Quaternary International 132:47-59.

Marchelli P, Smouse PE, and Gallo LA (2012) Short-distance pollen dispersal for an outcrossed, windpollinated southern beech (Nothofagus nervosa (Phil.) Dim. et Mil. Tree Genetics \& Genomes 8:1123-1134.

Marchelli P and Gallo L (2006) Multiple ice-age refugia in a southern beech of South America as evidenced by chloroplast DNA markers. Conservation Genetics 7:591-603.

Marchelli P and Gallo LA (2004) The combined role of glaciation and hybridization in shaping the distribution of genetic variation in a Patagonian southern beech. Journal of Biogeography 31:451460.

Markgraf V, Whitlock C, Anderson RS, García A (2009) Late Quaternary vegetation and fire history in the northernmost Nothofagus forest region: Mallín Vaca Lauquen, Neuquén Province, Argentina. Journal of Quaternary Science 24(3):248-258.

Markgraf V, D’Antoni HL, Ager TA (1981) Modern pollen dispersal in Argentina. Palynology 5(1):4363.

Markgraf V and D’Antoni HL (1978) Pollen Flora of Argentina. Arizona: University of Arizona Press. 
Mermoz M, Kitzberger T, Veblen TT (2005) Landscape influences on occurrence and spread of wildfires in Patagonian forests and shrublands. Ecology 86(10):2705-2715.

Motecinos A and Aceituno P (2003) Seasonality of the ENSO-Related rainfall variability in Central Chile and associated circulation anomalies. Journal of Climate 16:281-296.

Montiel M, Gonzalez ME, Crisafulli CM (2016) Caída de tefra y su influencia sobre la estructura y dinámica de los bosques andinos de Nothofagus en el Parque Nacional Puyehue, Chile. Anales Instituto Patagonia 44(3):5-11.

Moreno PI, Francois JP, Moy CM et al. (2010) Covariability of the Southern Westerlies and atmospheric $\mathrm{CO} 2$ during the Holocene. Geology 38(8):727-730.

Moy CM, Seltzer GO, Rodbell DT et al. (2002) Variability of El Niño/Southern Oscillation activity at millennial timescales during the Holocene epoch. Nature 420:162-165.

Naranjo JA, Moreno H, Emparan C et al. (1993) Recent explosive volcanism in the Sollipulli caldera, Southern Andes (395). Revista Geológica de Chile 20:167-191.

Naranjo JA and Moreno H (1991) Postglacial explosive activity at Llaima Volcano, Southern Andes (3845'S). Revista Geológica de Chile 18:69-80.

Oksanen J, Blanchet FG, Friendly M et al. (2017) Package vegan. Community Ecological Package.

Paredes M (2003) Caracterización genética de poblaciones de Nothofagus obliqua (Mirb.et Oerst) y Nothofagus alpina (Poepp. et Endl.) Oerst. (=N. nervosa (Phil.) Dim. et Mil.) mediante marcadores moleculares e isoenzimáticos. Informe Técnico Final, Fondo regional de Tecnología Agropecuaria (FONTAGRO).

Pastorino JM and Gallo LA (2002) Quaternary evolutionary history of Austrocedrus chilensis, a cypress native to the Andean-Patagonian forest. Journal of Biogeography 29:1167-1178.

Piazza MV, Kitzberger T, Chaneton EJ (2018) La deposición de cenizas volcánicas modula la descomposición de hojarasca en bosques de Nothofagus dombeyi del norte de Patagonia. Ecología Austral 28:028-039.

Pickett STA and White PS (1985) Patch Dynamics: A Synthesis. In: Pickett STA, White PS (eds) The Ecology of Natural Disturbance and Patch Dynamics. Orlando, Florida: Academic Press, pp.371-386.

Premoli AC, Kitzberger T, Veblen TT (2000) Isozyme variation and recent biogeographical history of the long-lived conifer Fitzroya cupressoides. Journal of Biogeography 27:251-260.

Premoli A (1991) Morfología y capacidad germinativa en poblaciones de Nothofagus antarctica (G. Forster) Oerst. del noroeste andino-patagónico. Bosque 12:53-59.

Prentice $\mathrm{Cl}$ (1985) Pollen representation, source area, and basin size: toward a unified theory of pollen analysis. Quaternary Research 23:76-86. 
R Development Core Team (2017) R: a language and environment for statistical computing. R Foundation for Statistical Computing, Vienna, Austria Available at: www.R-project.org

Ramírez C, San Martín C, Oyarzún A et al. (1997) Morpho-ecological study on the South American species of the genus Nothofagus. Plant Ecology 130:101-109.

Ramírez C, Figueroa H (1987) Fitosociologia de los Nothofagus de la zona higromorfica Chilena. Bosque 2:127-132.

Rehfeldt G and Gallo LA (2001) Introduction of ponderosa pine and Douglas-fir to Argentina. New Forests 21:35-44.

Reimer PJ, Bard E, Bayliss A et al. (2013) IntCal13 and Marine13 radiocarbon age calibration curves, 0-50,000 years cal BP. Radiocarbon 55:1869-1887.

Sabatier Y, Azpilicueta M.A, Marchelli P et al. (2011) Distribución natural de Nothofagus alpina y Nothofagus obliqua (nothofagaceae) en Argentina, dos especies de primera importancia forestal de los bosques templados norpatagónicos. Boletín de la Sociedad Argentina de Botánica 46 (1-2):131138.

Schlichter TM and Laclau P (1998) Ecotono estepa-bosque y plantaciones forestales en la Patagonia norte. Ecología Austral 8(2):285-296.

Simi E, Moreno PI, Villa-Martínez R et al. (2017) Climate change and resilience of deciduous Nothofagus forests in central-east Chilean Patagonia over the last 3200 years. Journal of Quaternary Science 32(6):845-856.

Stevenson J and Haberle S (2005) Macro Charcoal Analysis: A modified technique used by the Department of Archaeology and Natural History.

Stine S and Stine M (1990) A record from Lake Cardiel of climate change in southern South America. Nature 345:705-708.

Szceicz JM, Zeeb BA, Bennett KD et al. (1998). High-resolution paleoecological analysis of recent disturbance in a southern Chilean Nothofagus forest. Journal of Paleolimnology 20:235-252.

Ter Braak CJF and Smilauer P (2012) CANOCO Reference Manual and CanoDraw for Windows User's Guide: Software for Canonical Community Ordination (version 5.0). Microcomputer Power, Ithaca, NY, USA. Available at: http://www. Canoco.com/

Theurillat JP and Guisan A (2001) Potential impact of climate change on vegetation in the European Alps: a review. Climate Change 50:77-109.

Turner MG, Baker WL, Peterson CJ et al. (1998) Factors Influencing Succession: Lesson from Large, Infrequent Natural Disturbances. Ecosystems 1:511-523.

Veblen TT, Kitzberger T, Raffaele E et al. (2003) Fire History and Vegetation Changes in Northern Patagonia, Argentina. In: Veblen TT, Baker WL, Montenegro G, Swetnam TW (eds) Fire and Climatic 
Change in Temperate Ecosystems of the Western Americas. Ecological Studies, vol. 160 New York: Springer-Verlag, pp.265-295.

Veblen TT, Kitzberger T, Donnegan J (2000) Climatic and human influences on fire regime in Ponderosa pine forest in the Colorado Front Range. Ecological Applications 10(4):1178-1195.

Veblen TT, Kitzberger T, Villalba R et al. (1999) Fire history in northern Patagonia: the roles of humans and climatic variation. Ecological Monographs 69:47-67.

Veblen TT, Kitzberger T, Lara A (1992) Disturbance and forest dynamics along a transect from Andean rain forest to Patagonian shrubland. Journal of Vegetation Science 3:507-520.

Veblen TT and Lorenz DC (1988) Recent Vegetation Changes along the Forest/Steppe Ecotone of Northern Patagonia. Annals of the Association of American Geographers 78(1):93-111.

Veblen TT, Ashton DH, Schlegel FM, Veblen AT (1977) Plant succession in a timberline depressed by vulcanism in south-central Chile. Journal of Biogeography 4:275-294.

Villagrán C (1991) Historia de los bosques templados del sur de Chile durante el Tardiglacial y Postglacial. Revista Chilena de Historia Natural 64:447-460.

Villalba R, Lara A, Boninsegna JA et al. (2003) Large-scale temperature changes across the southern Andes: 20th-century variations in the context of the past 400 years. Climatic Change 59:177-232.

Villalba R and Veblen TT (1997) Spatial and temporal variation in Austrocedrus growth along the forest-steppe ecotone in northern Patagonia. Canadian Journal of Forest Research 27:580-597.

Whitlock C, Bianchi MM, Bartlein PJ et al. (2006) Postglacial vegetation, climate, and fire history along the east side of the Andes (lat $41-42.5^{\circ} \mathrm{S}$ ), Argentina. Quaternary Research 66:187-201.

Wright HE Jr (1967) A square-rod piston sampler for lake sediments. Journal of Sedimentary Petrology 37:975-976.

Young KR and León B (2007) Treeline changes along the Andes: implications of spatial patterns and dynamics. Philosophical Transactions of the Royal Society B: Biological Sciences 362:263-272. 


\section{Chapter 6}

11000 years of vegetation dynamics, fire regimes, and volcanic activity near Lake Lácar Basin, Lanín National Park, Province of Neuquén, Argentina. 


\section{Abstract}

Western northern Patagonia Argentina provides a unique opportunity to analyse changes in mesic Nothofagus forest and so far, little is known about the past vegetation dynamics in mid-elevation areas close to the eastern slope of the Andes Cordillera. Fire and volcanic ash deposition are important disturbance agent recognized in the region and several current studies have demonstrated their role in shaping the vegetation. The present work revealed $11700 \mathrm{cal}$. yr BP of vegetation history, fire, and volcanic activity south of the Lácar basin $\left(40^{\circ} 12^{\prime} \mathrm{S} ; 71^{\circ} 30^{\prime} \mathrm{W} ; 1095 \mathrm{~m}\right.$ a.s.l.). The results indicate a dry Early Holocene with the probable dominance of Nothofagus antarctica and a diverse herbaceous and shrub stratum. The rise in Austrocedrus chilensis during the Mid-Holocene is associated with long fire-free periods. A shift in fire frequency and fire magnitude resulted in the diminishing of this conifer. The Late Holocene was characterized by the establishment of Nothofagus alpina and Nothofagus obliqua within the Lácar basin. The redundancy analysis performed indicated that among the fire, and ash deposition variables, the fire return interval is the most important variable explaining vegetation changes. Variations in the abundance of Poaceae, A. chilensis, $N$. dombeyi-type, and $N$. obliqua-type characterized the changes in vegetation composition throughout the Holocene. Finally, the results here presented do recognize the major role of climatic forces in modelling the vegetation as well as in the predisposition of the vegetation which, somehow, determines the vegetation response to disturbance agents.

Key words: Holocene, fire, ash deposition, Cupressaceae, Nothofagus

\subsection{Introduction}

The modern vegetation of Patagonia is the result of a combination of topography and precipitation gradient. Humid to hyperhumid conditions along the western slope of the Andes allows the presence of a dense and diverse evergreen temperate forest (Villagrán, 1991). In eastern Andes slopes the vegetation shift into open woodlands/shrublands whilst in more arid areas, steppe elements dominate (Anchorena and Cingolani, 2002; Paruelo et al., 1998). This west-east precipitation gradient triggers the presence of the forest-steppe ecotone (Kitzberger, 2012).

Since the vegetation responds to this sharp change in precipitation, many studies have been conducted on past vegetation change in Patagonia with the aim to elucidate the changes in the position of the westerly flow throughout the postglacial (Iglesias et al., 2011; Moreno and Videla, 2016; Saunders et al., 2018; Villa-Martínez and Moreno, 2007; among others). Additionally, the northern Patagonian region also offers the opportunity to assess how the vegetation responds to 
natural disturbance agents, such as volcanic eruptions and fires, as well as to anthropogenic causes like animal husbandry, clear-cutting, and the introduction of exotic species.

The present work attempts to understand the past vegetation dynamics in one of the most important centres of biological diversity in northern Patagonia Argentina: The Lake Lácar basin within the Lanín National Park, Province of Neuquén, Argentina (Administración de Parques Nacionales, 2012; Eskuche, 1999). The area is dominated by the evergreen Nothofagus dombeyi, the deciduous Nothofagus antarctica, and Nothofagus pumilio, and by the conifer Austrocedrus chilensis. All these species have been largely affected by fires, especially during the dry season and recent volcanic eruptions resulted in vegetation burial (González et al., 2014). In addition to the species already mentioned, the Lácar basin comprises one of the largest Argentinean populations of two deciduous southern beech species: Nothofagus alpina and Nothofagus obliqua (Sabatier et al., 2011).

Given their commercial value, the populations of both species have been intensively degraded while efforts in restoration and conservation have triggered numerous publications on their genetic characterization. This, with the aim to define genetic zones with the purpose of highlight the genetic identity of both species and then, improve silvicultural management (Azpilicueta et al., 2016; Azpilicueta et al., 2014; Paredes, 2003). So far, only one palynological record discuss the Holocene history of Nothofagus obliqua in their northernmost Argentinean distribution (Markgraf et al., 1987 and 2009; Lagunas de Epulauquén, $36^{\circ} 49^{\prime} \mathrm{S}, 71^{\circ} 04^{\prime} \mathrm{W}$ ), whereas in their southern Argentinean distributions there are no palynological records with the presence of Nothofagus obliqua or Nothofagus alpina hitherto. On the other hand, in the west Andean distribution of both Nothofagus alpina and Nothofagus obliqua some palynological records indicate the presence of their pollen type (De Batist et al., 2007; Moreno et al., 2018; Villagrán, 1980).

Here are presented the results obtained from a lake sediment-core located at $2 \mathrm{~km}$ south of the Lácar basin with the aim to (i) describe the Holocene vegetation changes; (ii) to determine the effect of fires and volcanic ash deposition on vegetation composition and (iii) to analyse the changes in Nothofagus obliqua/Nothofagus alpina during the Holocene 


\subsection{Study area}

\subsubsection{Climate and topography}

The climate in the Lanín National Park (LNP) is warm-temperate with oceanic influence. Mean winter and summer temperatures are $4.1^{\circ} \mathrm{C}$ and $20.1^{\circ} \mathrm{C}$ respectively (Administración de Parques Nacionales, 2012). A west-east humid gradient characterizes this region due to the rain shadow effect induced by the Andes Cordillera, acting as an obstacle for the westerly flow, which bring humid air masses coming from the Pacific Ocean (Garreaud, 2009). The precipitation decreases from $3000 \mathrm{~mm}$ per year to $<600 \mathrm{~mm}$ in just $50 \mathrm{~km}$ in a west-east gradient. This change in precipitation results in the sharp vegetation gradient characteristics of Patagonia.

The territory of the LNP located within the Andes is part of a geological fault, the Liquiñe-Ofqui Fault Zone (LOFZ) oriented north-north-east (Diraison et al., 1998) then, part of the landscape has been modelled by tectonic forces. On the other hand, the LNP is located on ancient volcanic rocks, mainly characterized by basaltic plateaux (Iriondo, 1989). The Quaternary glaciations also have played a role in shaping the modern topography creating moraines and the characteristics lakes of this region (Coronato et al., 2004; Glasser et al., 2008). The lakes present in the LNP exhibit an elongated shape oriented west-east (Diaz et al., 2000).

\subsubsection{Vegetation}

The temperate forest characteristic of this region is mainly composed by southern beech species Nothofagus. At low and middle altitudes ( 600-1000 m a.s.l.) Nothofagus dombeyi dominates, especially on more humid sites such as slopes with western aspect and following rivers and streams (Administración de Parques Nacionales, 2012). Between 650 and 800 m a.s.I., Nothofagus obliqua occurs on slopes with a north-east aspect. Nothofagus alpina can be found between 950 until 1150 $\mathrm{m}$ a.s.I. and can form pure stands. Usually, it is present on slopes with north-west aspects (Sabatier et al., 2011). At highest altitudes (> $1000 \mathrm{~m}$ asl) Nothofagus pumilio becomes the dominating tree and forms the treeline. Nothofagus antarctica occurs is swampy areas as well as toward dry areas close to the steppe. Most of the Nothofagus species present in the study area are colonized by the epiphyte Misodendrum. Other epiphytes present in the study area is the fern Polypodium feuillei, Tristerix corymbosus (Loranthaceae), and Lepidoceras kingii (Eremolepidaceae). The evergreen liana Hydrangea serratifolia infest several tree species in the region (Jimenez-Castillo and Lusk, 2009). The understory is composed by the bamboo Chusquea, Drimys andina, Aristotelia chilensis, 
Maytenus, Berberis, Embothrium coccineum and Lomatia hirsuta (Conticello et al., 1996). Towards the east, following the decrease in precipitation, Nothofagus antarctica occurs together with Austrocedus chilensis, Maytenus boaria, and Schinus patagonicus. However, at the border with the steppe, only scattered individuals of Austrocedrus chilensis occur (Veblen et al., 1995). The steppe is characterized by herbs and shrubs such as Poaceae, Asteraceae, Chenopodiaceae, Discaria, Gaultheria, Acaena, Eryngium, among others. Since part of the focus of this study is to discuss the past vegetation history of Nothofagus alpina and Nothofagus obliqua during the Holocene, the main ecological characteristics of both species are highlighted in the following.

Nothofagus alpina is a deciduous tree. Its population size in Argentina is about twice the size of Nothofagus obliqua. According to Sabatier et al. (2011), this species occurs in a latitudinal range from $39^{\circ} 21^{\prime} \mathrm{S}$ (northern limit; $1500 \mathrm{~mm} /$ year at Lake Quillén and Lake Tromen) to $40^{\circ} 35^{\prime} \mathrm{S}$ (southern distribution; 2500-1000 mm/year at Lago Espejo in Nahuel Huapi National Park). N. alpina develops better on soils with a high organic matter content, $\mathrm{pH}>5.2$, and on soils with high phosphate retention (Frugoni et al., 2005). Around Lake Lácar, N. alpina occurs sporadically at low altitudes ( $600 \mathrm{~m}$ a.s.l.), however, the tree becomes abundant between $950 \mathrm{~m}$ a.s.l. and $1350 \mathrm{~m}$ a.s.l., with scattered occurrences until 1500 m a.s.I. where N. pumilio dominates.

Major populations of Nothofagus obliqua occur with mean annual precipitation between 1200 and $2300 \mathrm{~mm} /$ year (Sabatier et al., 2011). Around Lake Lácar, this species is present at lower elevations (650 to $800 \mathrm{~m}$ asl). A small population occurs at 36 48'S (around Lagunas de Epulauquen; 1500$1000 \mathrm{~mm}$ /year), being the northernmost limit of this species (Azpilicueta et al., 2014). According to Sabatier et al. (2011), the easternmost population of Nothofagus obliqua is located within the steeply incised valley of the Aluminé River $\left(39^{\circ} \mathrm{S}, 70^{\circ} \mathrm{W}\right)$, with a mean precipitation of $682 \mathrm{~mm} /$ year (Azpilicueta et al., 2007). This deciduous tree is more tolerant to long-dry periods in comparison to Nothofagus alpina and it is capable to grow in less favourable sites (thin and rocky soils). The soils in which this tree occurs exhibit high organic carbon values (Satti et al., 2003) and it seems to have a tendency for alkaline soils (Frugoni et al., 2005)

In their Chilean distribution, Nothofagus alpina grow on deep volcanic soils, moderately acidic (Donoso, 2013). Within a Mediterranean climate-type, this species occurs above $700 \mathrm{~m}$ and in south exposure areas as well on ravines. In its north distribution range, Nothofagus alpina grows between 700 and $2000 \mathrm{~m}$ a.s.l. whereas towards the south, it grows between 0 and $500 \mathrm{~m}$ (Donoso, 2013). On the other hand, Nothofagus obliqua grows in the Coastal Cordillera of Chile at an elevation between 700 and 2000 m, reaching the highest altitude in the northern part of the Coastal cordillera. 
Within the Andes, the populations occur between 1000 and $2000 \mathrm{~m}$ a.s.l. in the north part, while in southern Andes is present between 0 and $500 \mathrm{~m}$, being replaced by other Nothofagus species at highest elevations. According to Di Castri and Hajek (1976), Nothofagus obliqua grows in regions where the mean temperature of the coldest month fluctuates between $0^{\circ}$ and $10^{\circ} \mathrm{C}$ and the mean temperature of the warmest month varies between $10^{\circ}$ and $20^{\circ} \mathrm{C}$. In general, both species are important components of the Lowland Deciduous Forest and are characteristic species of the Mediterranean region of Chile (Donoso, 2013).

\subsubsection{Study site}

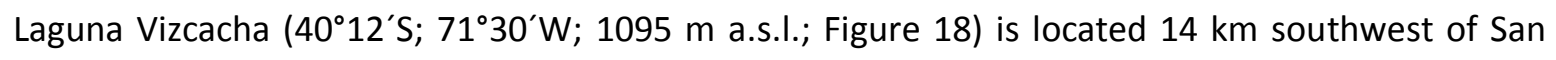
Martín de los Andes (Province Neuquén). It is a small lake with a depth of $2.5 \mathrm{~m}$ within a larger peat filled depression in the saddle between the adjacent mountains (Figure 18b). Potamogeton forms a ring at the edges of the lake. The shrubs of Escallonia virgata and Berberis microphylla encircle the lake. While Sphagnum mosses occur beside the lake the rest of the wetland is dominated by Cyperaceae. The southern beech genus Nothofagus, characteristic of the temperate forest of South America, is present around lake Vizcacha with five species: Nothofagus antarctica, Nothofagus dombeyi, Nothofagus pumilio, and Nothofagus alpina. The understory is mainly dominated by the bamboo Chusquea sp and Drimys andina. 


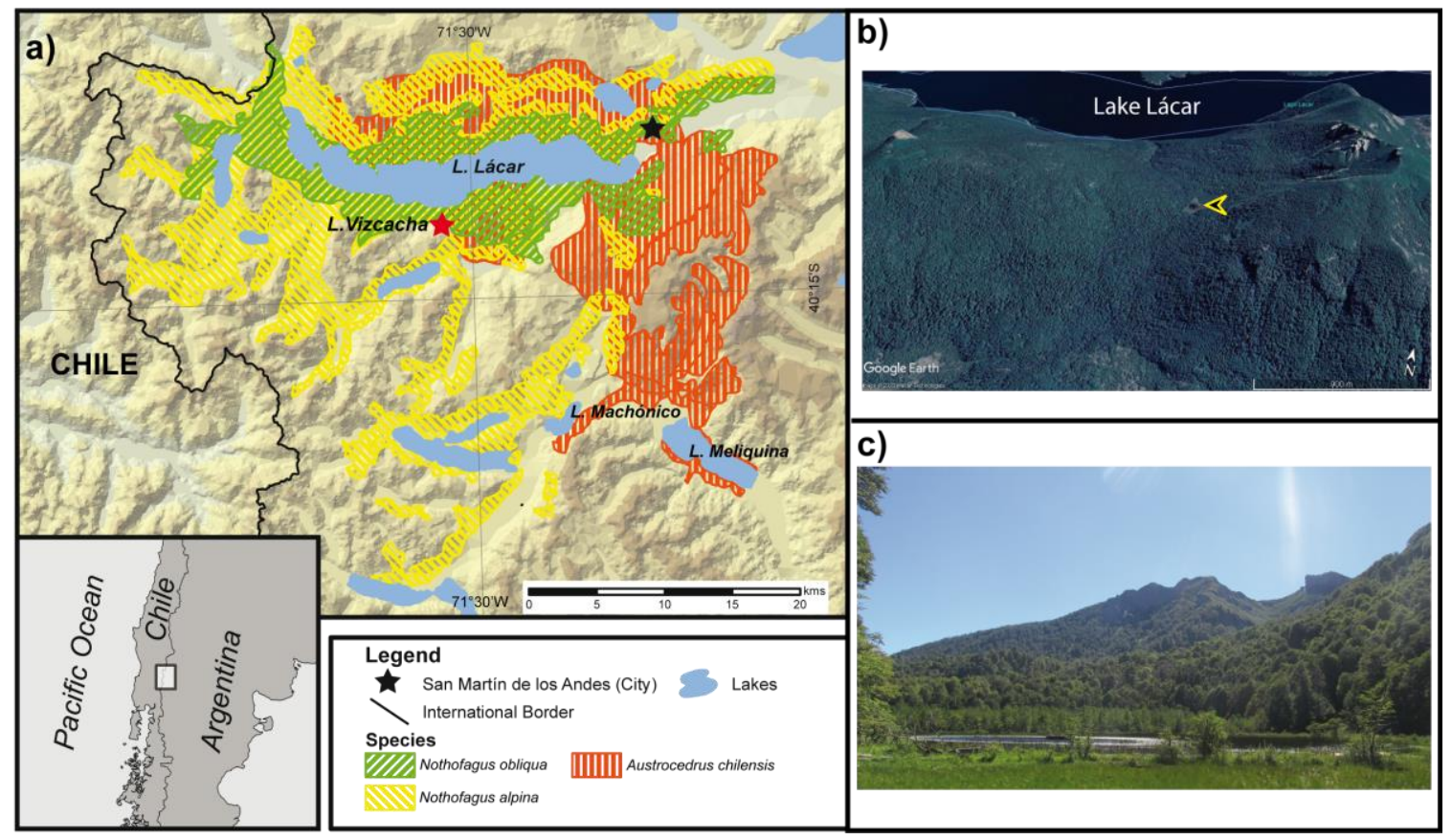

Figure 18. a) Map with the location of the study site referred in this study (red star), and the current distribution of Nothofagus alpina, Nothofagus obliqua, and Austrocedus chilensis around Lake Lácar basin based on Sabatier et al. (2011); Dezzotti and Sancholuz (1991); Administración de Parques Nacionales (2012). b) topography around lake Vizcacha taken from @Google Earth. c) photography of lake Vizcacha taken during fieldwork.

\subsection{Material and Methods}

A $580 \mathrm{~cm}$ long sediment core was retrieved from laguna Vizcacha using a modified square rood piston corer (Wright, 1967). The sediment-water interface was collected using a gravity corer and subsampled in the field as $1 \mathrm{~cm}$ thick slices, stored in plastic bags. The lithological description was based on textural characteristic and loss-on-ignition analysis (Heiri et al., 2001). Pollen samples of $0.5 \mathrm{~cm}^{3}$ were taken at a $2 \mathrm{~cm}$ interval, avoiding tephra sections. Before and after major tephra layers the sampling was carried out at $1 \mathrm{~cm}$ interval. The chemical processing of the samples was conducted following Bennett and Willis (2001). Samples with coarse particles were sieved at $120 \mu \mathrm{m}$.

Nothofagus trees are high pollen producers and wind-pollinated, while low pollen producers taxa are mainly insect-pollinated. Therefore, a minimum of 500 pollen grains was counted to reduce the uncertainty in estimating the frequency of less abundant pollen types (Birks and Birks, 1980). Aquatic pollen and spore taxa were excluded from the main pollen sum and were calculated separately based on the terrestrial pollen sum. Cyperaceae pollen was included among the aquatics and exclude from the main pollen sum since it occurs at the edges of the lake. Pediastrum and 
Botryococcus were counted with the aim to infer changes in the aquatic system. Non-pollen palynomorphs were used in order to add details at the environmental history recorded in Vizcacha core, with emphasis on the identification of Glomus sp, Gelasinospora, Microthyrium sp, and coprophilous fungal spores. Percentages were calculated based on the main pollen sum. All the pollen and spore identifications were based on pollen atlas (Heusser, 1971; Markgraf and D'Antoni, 1978), as well as using reference material from the Department of Palynology and Climate Dynamics of the University of Göttingen. Non-pollen palynomorphs were identified aided by descriptions collected at http://nonpollenpalynomorphs.tsu.ru/

Rarefaction analysis $(E(T n))$ was carried out following the methodology outlined by Birks and Line (1992) using the vegan package in R (Oksanen et al., 2018), to estimate the diversity from pollen assemblages at a temporal scale. The pollen diagram and associated constrained cluster analysis (CONISS) were constructed using Tilia 2.0.41 (Grimm, 2004) based on pollen percentages. A summary diagram with statistical results was created using C2 (Juggins, 2003). Principal Component Analysis (PCA) and Redundancy Analysis (RDA) were performed with CANOCO 5.0 (Ter Braak and Šmilauer, 2012) with square root transformation of percentage data in order to suppress the influence of dominant taxa. The compositional gradient as assessed by DCA is only 1.8 SD units long, which means that although the underlying responses may be unimodal, this dataset only shows shifts in abundances, best analysed with linear response models.

The sediments contained several tephra layers and it was assessed the impact of ash deposition on the vegetation using two approaches. It was evaluated the distance in $\mathrm{cm}$ of each sample to the prior tephra layer assuming that the influence of the tephra deposition on the vegetation would decay linearly with time and secondly assuming an exponentially as exp $x^{-\alpha t}$ decay of the influence in time following Lotter and Birks (1993). In this work, the formula was modified in order to add the magnitude of the impact (volcanic eruption) using the tephra thickness $(\mathrm{cm})$. Hence, $x$ is the thickness value $(\mathrm{cm})$ of each tephra, $\alpha$ is the decay coefficient ( 0.5 as it is suggested by the authors) and, $\mathrm{t}$ is the distance $(\mathrm{cm})$ of each sample to the prior tephra layer. The results were used as an environmental variable in the RDA under the name of decay.

The age model is based on smooth-spline interpolation between six radiocarbon dates, calibrated with SHCal13.14C (Reimer et al., 2013) using Clam 2.0 (Blaauw, 2010). Prior to the construction of the age model an adjusted depth was created subtracting tephra layers $>1 \mathrm{~cm}$ in thickness. In addition, two control points were used in constructing the depth to age relationship. The first (Cp1) correspond at the year of the coring (2017) assigned at the uppermost sample. The second control 
point ( $\mathrm{Cp} 2$ ) correspond to the rise in the percentage of Rumex acetosella (human indicator taxa), with an age of $1880 \pm 10$ (Rehfeldt and Gallo, 2001). Results and discussion indicate adjusted depths.

Table 6. Chronological control points.

\begin{tabular}{|c|c|c|c|c|c|c|c|}
\hline $\begin{array}{l}\text { Lab. } \\
\text { code }\end{array}$ & ID sample & Material type & ${ }^{14} \mathrm{C}$ age & \pm & $\begin{array}{c}\text { Calibrated } \\
\text { age }\end{array}$ & $\begin{array}{l}\text { Adjusted } \\
\text { depth } \\
\text { (cm) }\end{array}$ & $\begin{array}{l}\text { Assigned } \\
\text { age }\end{array}$ \\
\hline & Cp 1 & Core top & & & -67 & 274 & 2017 \\
\hline & Cp 2 & $\begin{array}{l}\text { Rise of introduced } \\
\text { weeds. }\end{array}$ & & & 70 & 279 & $1880 \pm 10$ \\
\hline $\begin{array}{l}\text { UBA } \\
39236\end{array}$ & $306-306.5 \mathrm{~cm}$ depth & Bulk sediment & 630 & 20 & 622 & 304 & \\
\hline $\begin{array}{l}\text { UBA } \\
39235\end{array}$ & $444-444.5 \mathrm{~cm}$ depth & Bulk sediment & 2496 & 27 & 2576 & 360 & \\
\hline $\begin{array}{l}\text { Poz- } \\
115934\end{array}$ & $551-551.5 \mathrm{~cm}$ depth & Bulk sediment & 4580 & 30 & 5477 & 444.5 & \\
\hline $\begin{array}{l}\text { UBA } \\
39233\end{array}$ & $633-333.5 \mathrm{~cm}$ depth & Bulk sediment & 7670 & 39 & 8526 & 507.5 & \\
\hline $\begin{array}{l}\text { UBA } \\
39234\end{array}$ & $761-761.5 \mathrm{~cm}$ depth & Bulk sediment & 9412 & 36 & 10664 & 598.5 & \\
\hline $\begin{array}{l}\text { UBA } \\
29235\end{array}$ & $856-856.5 \mathrm{~cm}$ depth & Bulk sediment & 10120 & 50 & 11716 & 627.5 & \\
\hline
\end{tabular}

Past fire regimes were reconstructed from macro charcoal particles analysis carried out on $1 \mathrm{~cm}^{3}$ sample-volume taken at contiguous $1 \mathrm{~cm}$ intervals avoiding tephra layers $>1 \mathrm{~cm}$ thick. The samples were processed according to the methodology outlined by Stevenson and Haberle (2005). Particles $>125 \mu \mathrm{m}$ were counted under a binocular dissecting microscope and these charred particles were used as an indicator of local biomass burning (Whitlock and Anderson, 2003). The resulting data were analysed using CharAnalysis (Higuera et al., 2009). The raw charcoal counting was transformed into charcoal accumulation rates (CHAR; particles $\mathrm{cm}^{2} \mathrm{yr}^{-1}$ ). The record was interpolated to the median sample resolution ( $y r$ sample ${ }^{-1}$ ) of the record. Low-frequency CHAR (charcoal background) 
was estimated using a robust to outliers lowess smoother method with a 1000 -years window. Charcoal peaks were calculated as a ratio while the threshold was locally defined and noise distribution was determined by a Gaussian mixture model.

\subsection{Results}

\subsubsection{Chronology and stratigraphy}

The age-depth model for Vizcacha lake indicate a basal age of $11716 \mathrm{cal}$. yr BP for the sequence. The average resolution is $\sim 70$ years per sample while the median age resolution between samples is $\sim 62$ years. The sedimentation rate is $0.5 \mathrm{~mm} \mathrm{yr}^{-1}$ at the beginning of the record $(627.5 \mathrm{~cm}$ adjusted depth) shifting to $0.25 \mathrm{~mm} \mathrm{yr}^{-1}$ until $10700 \mathrm{cal}$. yr BP (601.5 cm adjusted depth), which correspond to the first peat section identified in the sediment core. Between 598.5-575.5 cm, the sedimentation rate increase in comparison with the prior section (0.3-0.4 $\mathrm{mm} \mathrm{yr}^{-1}$ ), probably explained by the change in the sediment composition which may indicate and increase in the water table, as it is inferred by the gyttja deposit that characterize this section. From $573.5 \mathrm{~cm}$, the sedimentation rate increase to $0.5 \mathrm{~mm} \mathrm{yr}^{-1}$ until the first centimetres of the peat section at 543.5 cm (9400 cal. yr BP). The second half of the peat section $(538.5$ and $507.5 \mathrm{~cm}$ depth $~ 9300-8500$ cal. yr BP) is characterized by a decline in the sedimentation rate $\left(0.4\right.$ to $\left.0.2 \mathrm{~mm} \mathrm{yr}^{-1}\right)$. After 8500 cal. $\mathrm{yr} \mathrm{BP}$, the sedimentation rate decline about $0.1 \mathrm{~mm} \mathrm{yr}^{-1}$ along the gyttja section, becoming faster from 4200 cal. yr BP $\left(0.3 \mathrm{~mm} \mathrm{yr}^{-1}\right)$. From $500 \mathrm{cal}$. yr BP (300 cm adjusted depth) toward the top of the core, the sedimentation rate increases up to $0.4 \mathrm{~mm} \mathrm{yr}^{-1}$. 


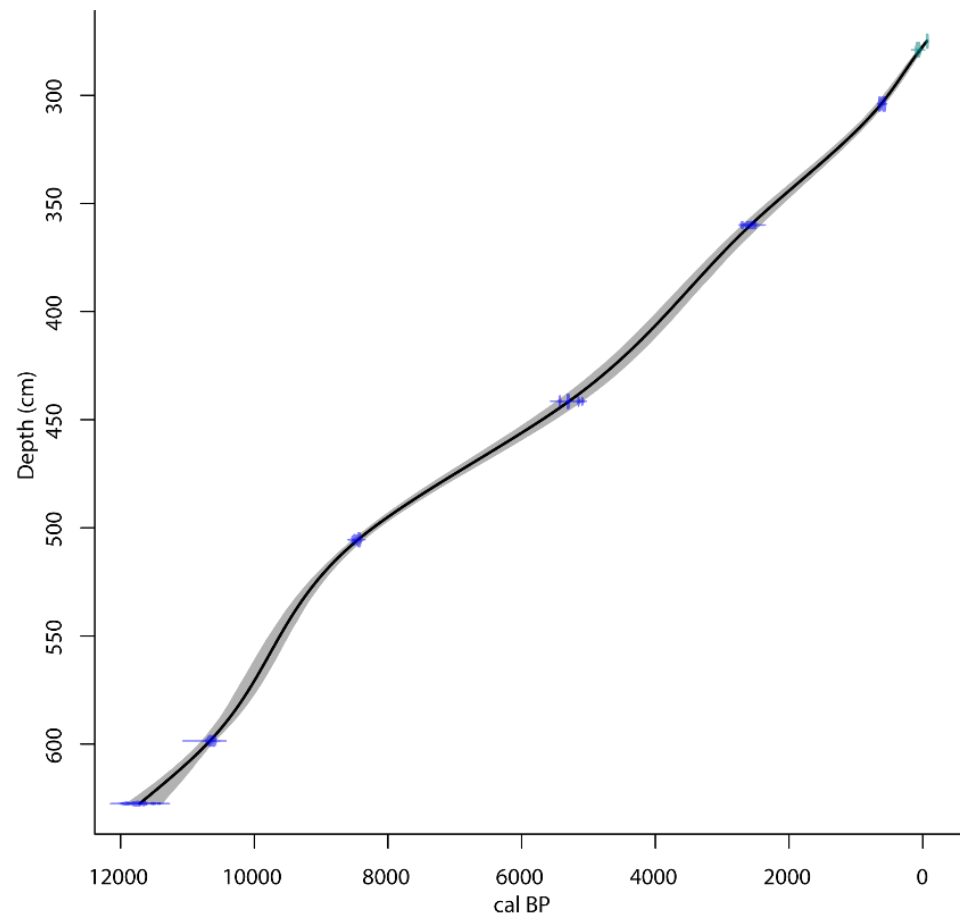

Figure 19. Age-depth model of Vizcacha record. Blue points represent 6 calibrated ages on bulk sediment while green points represent control points. Grey area represents $0.95 \%$ confidence interval.

Regarding the stratigraphy of the core, a detailed description is presented in Table 8 together with the results obtained from the loss on ignition analysis. In general, 26 tephra layers were identified as horizontal-greyish layers. Some of these layers are composed of angular particles (basalt) or distinguishable pumice particles up to $10 \mathrm{~mm}$ length. Besides tephra layers, two peat sections were identified, characterized by the presence of plant remains such as seeds, leaves (monocot and dicot), and wood-trunk pieces embedded on the core. Loss on ignition indicate high percentage (> $80 \%$ ) of organic matter content in those sections. On the other hand, brownish-gyttja section with different degrees of sediment consolidation constitute more than half of the core. 

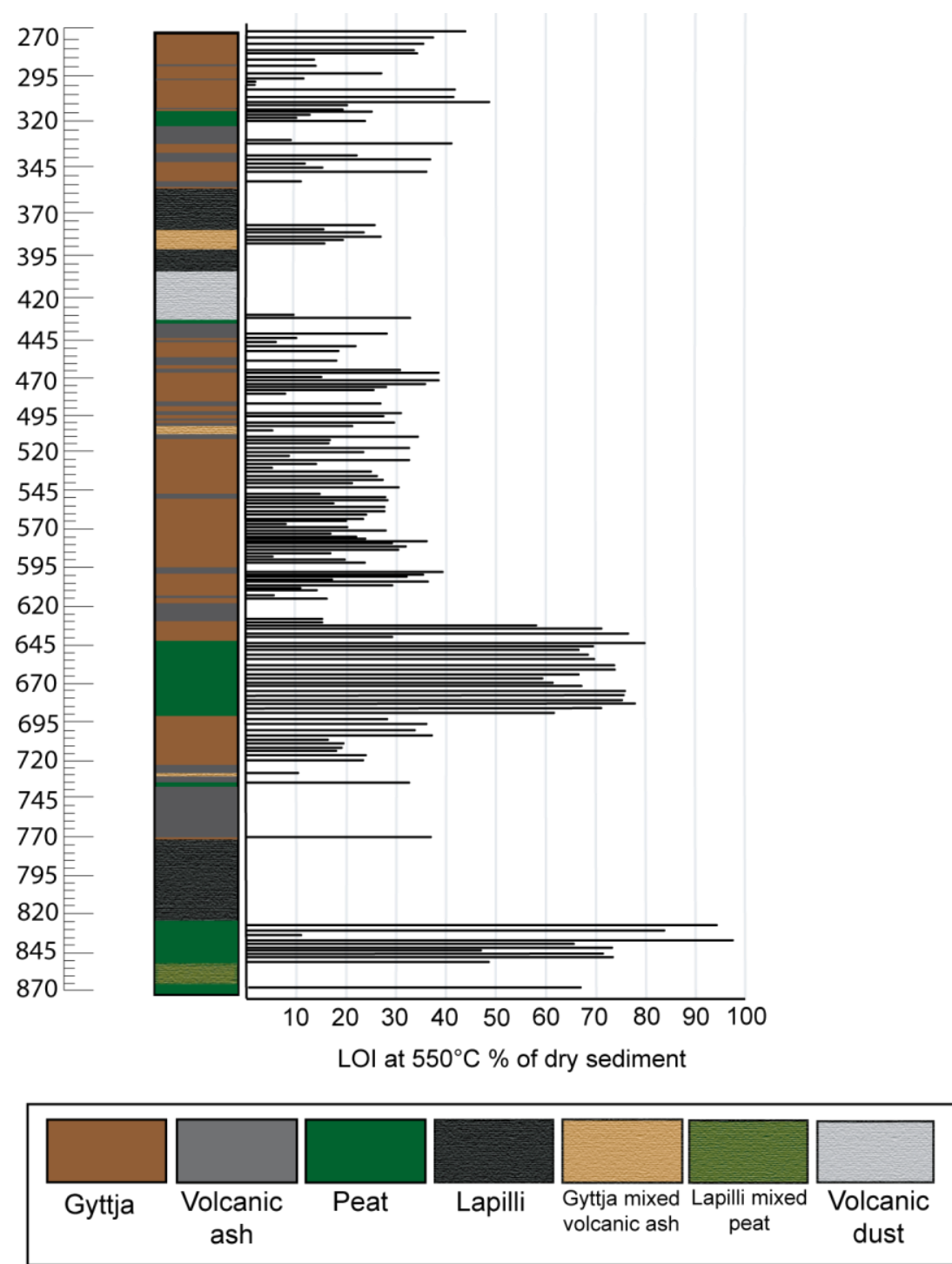

Figure 20. Lithology and loss on ignition results of Vizcacha core. Notice that loss on ignitions was conducted only on peat and gyttja sections excluding sediment dominated by tephra. $Y$ axis indicates original depths. 
Table 7. Sediment description. Depths are given relative to the water level of the lake.

\begin{tabular}{|c|c|c|}
\hline Depth (cm) & Age (cal. yr BP) & Sediment characteristics \\
\hline 275-375 & 1900-Present & $\begin{array}{l}\text { Brownish gyttja section with alternated greyish layers of volcanic ash } \\
\text { and } 5 \mathrm{~cm} \text { thick of a peat-muddy layer. LOI values between } 1 \text { to } 50 \%\end{array}$ \\
\hline $376-437$ & 2300-1900 & $\begin{array}{l}\text { Thick tephra layer composed mainly this section. Tephra particles and } \\
\text { colour varies from dark to light grey. A clayey-gyttja section exhibit } \\
20-30 \% \text { of organic matter content. }\end{array}$ \\
\hline 438-634 & $8400-2300$ & $\begin{array}{l}\text { Thick layers of brownish gyttja separated by several tephra layers and } \\
\text { a thin layer of gyttja mixed with ash. LOI indicates a variation of } 5 \text { to } \\
60 \% \text {. }\end{array}$ \\
\hline $635-682$ & $9700-8400$ & $\begin{array}{l}\text { Peat section characterized by the presence of plant remains identified } \\
\text { under the stereomicroscope as Cyperaceae/Poaceae leaves, mixed } \\
\text { with Sphagnum fragments, and embedded wood-trunk pieces. LOI } \\
\text { results indicate } 60-80 \% \text { of organic matter. }\end{array}$ \\
\hline 683-715 & $10200-9700$ & Brownish gyttja section. LOI values fluctuate between 10 to $40 \%$ \\
\hline 716-813 & $10700-10200$ & $\begin{array}{l}\text { Two major greyish tephra layers with different particles sizes ( } 31 \text { and } \\
52 \mathrm{~cm} \text { thick) separated by a thin gyttja layer characterize this section. }\end{array}$ \\
\hline $814-856$ & $11700-10700$ & $\begin{array}{l}\text { Consolidate peat deposit with by the presence of plant remains } \\
\text { identified under the stereomicroscope as Cyperaceae/Poaceae } \\
\text { leaves, mixed with Sphagnum fragments, and embedded wood-trunk } \\
\text { pieces. LOI fluctuate between } 50-90 \% \text { organic matter, separated by a } \\
14 \mathrm{~cm} \text { thick of pumice ash layer. }\end{array}$ \\
\hline
\end{tabular}

\subsubsection{Pollen record}

The summary diagram (Figure 21) shows the main types of pollen, spores, and non-pollen palynomorphs and a short description of the main changes is provided in Table 9. Pollen assemblage zones were divided based on visual recognition of the major changes in the record, guided by the constrained cluster analysis (CONISS). The resulting CONISS dendrogram, based on terrestrial pollen taxa indicates that the stratigraphically constrained groups coincide with changes in stratigraphy. Nothofagus dombeyi-type is dominant throughout the record as the parent trees N. antarctica, $N$. dombeyi and N. pumilio are high pollen producers and dominate the forest around the lake at different elevations with different taxa. Most of the Cupressaceae type pollen likely originates from Austrocedrus chilensis, as the modern distribution of Fitzroya cupressoides and Pilgerodendron uviferum also producing this pollen type lies in regions hundred kilometres far to the south (Kitzberger et al., 2000; Rovere et al., 2002), while stands of Austrocedrus chilensis occur on northfacing slopes within a few km of laguna Vizcacha (Administración de Parques Nacionales, 2012).

The pollen diagram from Vizcacha documents mainly changes in the proportion of herbs and shrubs, while Nothofagus dombeyi-type fluctuates around 80\% throughout the entire record. Zones VIZ-1 (11700-10700 cal. yr BP) and VIZ-2 (10700-8500 cal. yr BP) are characterized by high percentages of Cyperaceae, Poaceae, and Chenopodiaceae pollen. Among non-pollen palynomorphs, 
Conidiospore, Glomus, Microthyrium, and Gelasinospora (fire indicator fungal spore) present their highest values between 11700 and 8500 cal. yr BP. Non-pollen palynomorphs such as Microthyrium (saprotrophic on plant remains) occurred as much in peat as gyttja sections indicating plant degradation (van Geel, 1978) as well as wetland desiccation (Mancini, 2009). The algae Botryococcus and Pediastrum are scarcely present during the Early Holocene suggesting a low productive environment (Markgraf et al., 2009). Likewise, microcharcoal particles reach the maximum values during this period.

Zone VIZ-3 (8500-2300 cal. yr BP) is characterized by a decrease in shrub and herbaceous pollentypes percentages, as well as an increase and later persistence of the mistletoe Misodendrum pollen percentage. The green-algae Botryococcus and Pediastrum increase gradually along this period. Cupressaceae exhibit the most noticeable percentage fluctuation in this zone. The rise in the percentage of Nothofagus obliqua-type defines zone VIZ-4 (2300-300 cal. yr BP). The zone VIZ-5 is defined by a decrease in $N$. dombeyi and $N$. obliqua pollen type and the presence of human indicator taxa Rumex acetosella, Plantago lanceolata, and Pinus. 


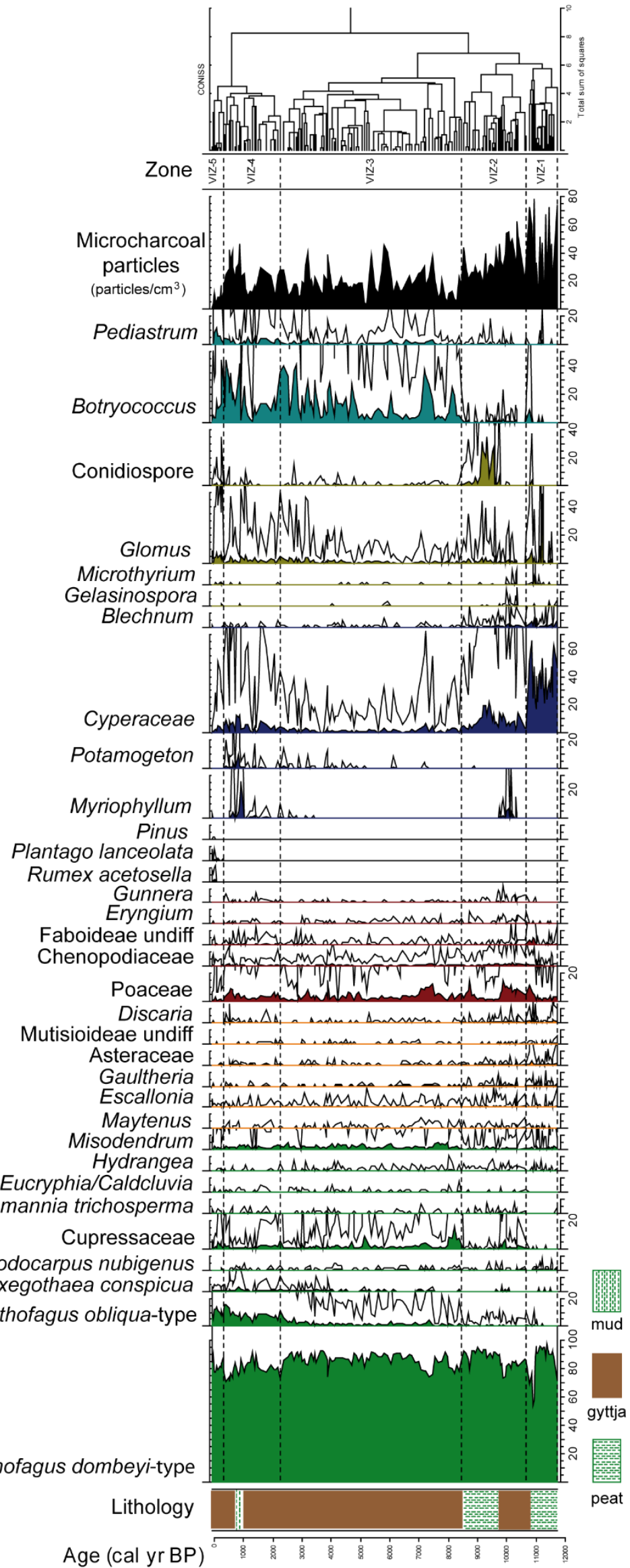

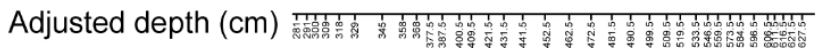

Figure 21. Percentage pollen, spores, and NPP's diagram showing selected taxa from Vizcacha record. A $10 \mathrm{X}$ exaggeration (grey pattern) was used to highlight less frequent taxa. Micro charcoal particles are expressed as percentage based on terrestrial pollen sum. Notice that the lithology shown here is just representing the main changes in sediment composition excluding tephras. 
Table 8. Vegetation history of Vizcacha record.

\begin{tabular}{|c|c|c|c|}
\hline Zone & Age & Pollen zone characteristics & Interpretation \\
\hline VIZ-5 & 300-Present & $\begin{array}{l}82 \% \text { mean for } N \text {. dombeyi-type, } 10 \% \text { for } N \text {. obliqua-type and } 1 \% \text { for Cupressaceae. Shrubs } \\
\text { and herbs decrease abruptly. This period is characterized by the presence of the human } \\
\text { indicator taxa (in order of appearance) P. lanceolata, } R \text {. acetosella, and Pinus. Aquatic taxa } \\
\text { decline in percentage, and some of them disappearfrom the record. Botryococcus decline and } \\
\text { Pedriastrum increase in this zone. }\end{array}$ & $\begin{array}{l}\text { Human activities close the lake, } \\
\text { especially timber extraction and grazing, } \\
\text { wetland disturbance and perhaps } \\
\text { eutrophication by cows. }\end{array}$ \\
\hline VIZ-4 & $2300-300$ & $\begin{array}{l}80 \% \text { mean for } N \text {. dombeyi-type. Rise in } N \text {. obliqua-type ( } 11 \% \text { since } 2200 \text { cal. yr BP) } \\
\text { Cupressaceae persist with scarce abundance }(<1 \%) \text {, with two peaks at the beginning and at } \\
\text { the end of this period ( } 1 \% \text { and } 3 \% \text { respectively). W. trichosperma and Eucryphia are present } \\
\text { in traces. Asteraceae, Discaria, Poaceae, and Fabaceae increase in } 1 \%, 0.5 \%, 3 \% \text {, and } 0.5 \% \\
\text { respectively. Myriophyllum, Potamogeton, and Cyperaceae increase in } 0.8 \%, 0.5 \% \text {, and } 3 \% \\
\text { during this period. Glomus reach } 2 \% \text { mean, Botryococcus } 2.5 \% \text { mean, and Pediastrum } 18 \% \\
\text { mean. }\end{array}$ & $\begin{array}{l}\text { N. obliqua/N. alpina populations around } \\
\text { the lake have established modern } \\
\text { dominance. Increased herbaceous } \\
\text { diversity, perhaps associated with a } \\
\text { lowering of the lake level. }\end{array}$ \\
\hline VIZ-3 & $8500-2300$ & $\begin{array}{l}85 \% \text { mean for } N \text {. dombeyi-type. Cupressaceae mark the beginning of this zone with an } \\
\text { increase from } 3 \% \text { to } 15 \% . N \text {. obliqua-type occurs along this period with a mean of } 2 \% . P \text {. } \\
\text { nubigenus and Eucryphia/Caldcluvia appear more contiguously }(<1 \%) \text {. Misodedrum is } \\
\text { abundant in this zone. Shrubs decline to } 1 \% \text { mean. Cyperaceae and Blechnum decline up to } \\
1.9 \% \text { and }<1 \% \text { respectively. Potamogeton occurs in this zone with scarce percentage }(<1 \%) \text {. } \\
\text { Gelasinospora and Microthyrium appear in traces and disappear visually from the record. } \\
\text { Glomus reaches }<5 \% \text {. Botryococcus and Pediastrum increase ( } 12 \% \text { and } 1 \% \text { mean each). }\end{array}$ & $\begin{array}{l}\text { Increase and fluctuations in A. chilensis } \\
\text { populations around lake Lácar basin. } \\
\text { Probable development of a mixed forest } \\
\text { Nothofagus/Austrocedrus. Stable water } \\
\text { table level. Wet conditions. }\end{array}$ \\
\hline VIZ-2 & $10700-8500$ & $\begin{array}{l}N \text {. dombeyi-pollen type decline up to } 80 \% \text { mean between } 10700 \text { and } 9500 \text { cal. yr BP } \\
\text { concomitant with a rise of Poaceae ( } 8 \% \text { ) and Cupressaceae (1.5\%), and a general increase in } \\
\text { the percentage of shrubs ( } 2 \% \text { mean) and herbs ( } 11 \% \text { mean). Decrease in the percentage of } \\
\text { Cyperaceae ( } 8 \% \text { mean) and the first appearance of Myriophyllum. Between } 9000 \text { and } 8500 \\
\text { cal. yr BP, } N \text {. dombeyi-type increase }(90 \% \text { mean); Escallonia and Chenopodiaceae increase } \\
\text { their percentage ( } 1 \% \text { each) while Poaceae decline abruptly to } 1 \% \text { but by the end of this zone } \\
\text { reach } 15 \% \text {. Cupressaceae pollen is almost not visible during this period. Myriophyllum } \\
\text { disappears during this interval and Cyperaceae percentage increase up to } 20 \% \text {. Conidiospore } \\
\text { percentage is the highest in this zone among the NPP'S }(0.5 \%) \text {. Gelasinospora reach its } \\
\text { maximum values in this zone ( } 1 \%) \text {. }\end{array}$ & $\begin{array}{l}\text { Diverse herbaceous and shrub stratum. } \\
\text { Water table fluctuation (wetland-lake } \\
\text { phases). Local fires. Shifts between dry } \\
\text { and wet conditions. }\end{array}$ \\
\hline VIZ-1 & 11700-10700 & $\begin{array}{l}\text { Mean } N \text {. dombeyi-type } 87 \% \text {, with an abrupt decrease to } 60 \% \text { at } 10900 \text { cal. yr BP. First } \\
\text { appearance of } N \text {. obliqua-type at } 11200 \text {, with a continuous curve }(<1 \%) 200 \text { years later. } \\
\text { Occurrence of Misodendrum around } 1 \% \text { and single grains of Cupressaceae pollen present. The } \\
\text { shrubs Escallonia, Gaultheria, Asteraceae, and Discaria characterize this period with less than } \\
2 \% \text {. Poaceae fluctuates between } 1-7 \% \text {, with a maximum at } 10700 \text { cal. yr BP. Cyperaceae } \\
\text { reaches its highest percentage }(60 \%) \text { being dominant among the aquatics together with } \\
\text { Blechnum (1\%). Microthyrium }(<1 \% \text { mean) and Glomus ( } 3.5 \% \text { mean) are important } \\
\text { component between the NPP'S. }\end{array}$ & $\begin{array}{l}\text { Nothofagus (likely N. antarctica) } \\
\text { dominating the landscape with steppe } \\
\text { elements. Wetland dominated by } \\
\text { Cyperaceae. Dry conditions. }\end{array}$ \\
\hline
\end{tabular}




\subsubsection{Numerical analysis of data}

The symbols of the sample scores in the PCA biplot (Figure 22) are according their affiliation to a pollen zone and together with the species scores of the 20 taxa with highest variance assist in the interpretation of the data. The first axis of the ordination explains $28 \%$ while the second axis explains 14\%. The PCA biplot of the first and second axis shows well-separated clusters. From left to right quadrant, group VIZ-1 is characterized by $N$. dombeyi and VIZ-2 by Poaceae. Samples from both clusters are dominated by steppe elements such as Discaria, Chenopodiaceae, Gaultheria, and Asteraceae. subf. Asteroideae. VIZ-3 group is characterized by Cupressaceae, Gunnera, Eryngium and Faboideae undiff. VIZ-4 is characterized by Eucryphia, Misodedrum, S. conspicua, and N. obliqua, while the introduced taxa $R$. acetosella and $P$. lanceolata characterized VIZ-5 group. The arrows in the PCA pointed in the direction of the species while the length is proportional to maximum rate of change (ter Braak and Prentice, 2004). Therefore N. dombeyi, Poaceae, Cupressaceae, and N. obliqua are the most important for indicating group differences. The species scores show a negative correlation between $N$. dombeyi-type and Cupressaceae, as it is indicated by the opposite direction of the arrows of both taxa.

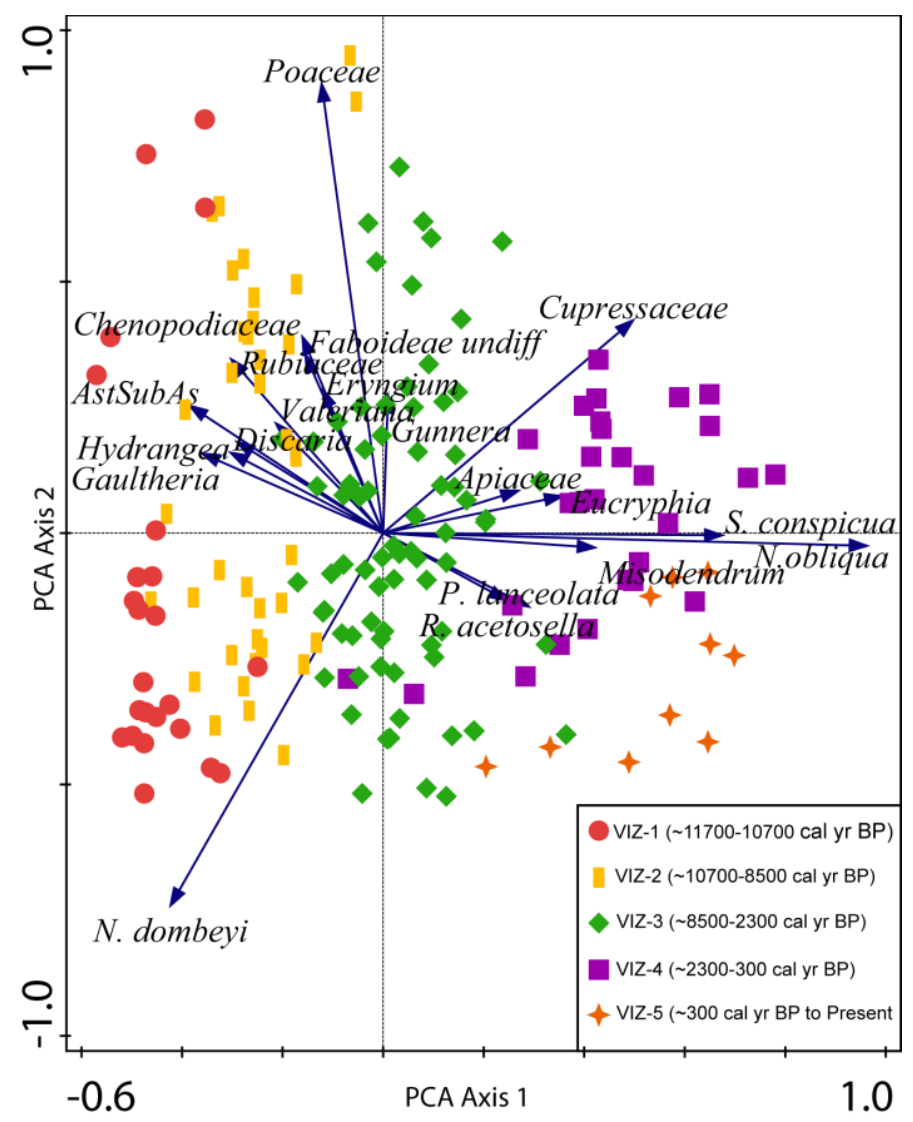

Figure 22. PCA scatterplot of samples and selected taxa of Lake Vizcacha. Grouping by CONISS shown by different symbols in the PCA. 
Based on the arrangement of the samples/species on the scatterplot, the first axis may be interpreted as a dry-to-wet gradient. Figure 23 shows the scores of PCA axis 1 showing an increase towards the topmost samples. This is well correlated with the percentage curve of N. obliqua-type along the record (see Figure 21). Likely, the inferred shift from dry to wet conditions is explaining somehow the direction of increment of $N$. obliqua during the Late Holocene. Sample scores from PCA axis 2 are related with the percentage of Poaceae (see Figure 21 and 23).

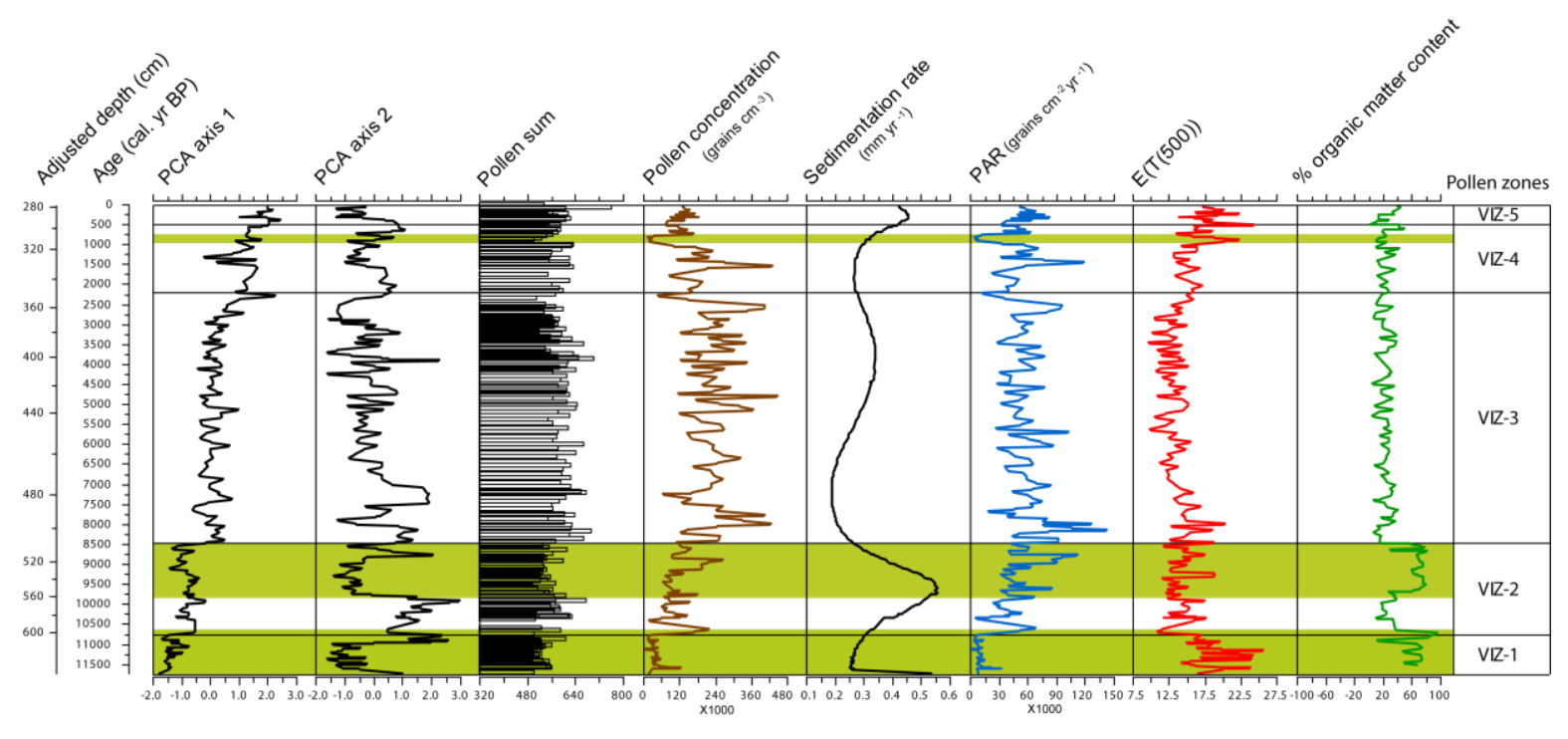

Figure 23. Summary diagram with the main result obtained from Vizcacha record. See upper label for details. Peat sections are highlighted in green.

Pollen concentration and pollen accumulation rate (PAR) exhibit their lowest values during the Early Holocene and beginning of the Mid-Holocene (Figure 23). This period is characterized by two peat sections separated by a gyttja segment. On peat sections, the pollen concentration and PAR features low values suggesting a fast sedimentation rate. In addition, samples taken from the peat section presented deteriorated pollen grain, most of them broken and barely distinguishable. This might be due to the lowered water table and the associated oxidation of pollen. Delcourt and Delcourt (1980) comparing full glacial records in south-eastern United States, indicate that periods of dry and warm climate conditions, coincide with desiccation of lakes and ponds, and lowering water levels in some lakes. These conditions allowed oxidation of the depositional environment creating less suitable conditions for pollen preservation. Unlike conditions were observed during warm and humid periods, which triggered the presence of permanent water table in lakes and pollen grains were well preserved. Microbial attack also has been reported as a cause of pollen degradation, especially in environments where the oxygen pressure and $\mathrm{pH}$ are high, damaging the pollen wall (Havinga, 
1967). On the other hand, on gyttja sections PAR and pollen concentration are high; pollen preservation is good, and the sedimentation rate is slow in comparison with the prior period, presenting several oscillations since $8500 \mathrm{cal}$. yr BP. No major changes in palynological richness were documented in Vizcacha record.

The redundancy analysis (RDA) was performed with the aim to assess which environmental variable account for the main variation in the sample composition. Figure 24 show the RDA ordination diagram of Vizcacha record. The environmental variables tested in this work were volcanic ash deposition (decay and distance) and fire (fire magnitude, fire frequency, fire return interval, and charcoal accumulation rate). As redundancy analysis is a canonical form of the PCA, the relationship between species and environmental variables can be interpreted in the same mode according to the length and direction of the arrows.

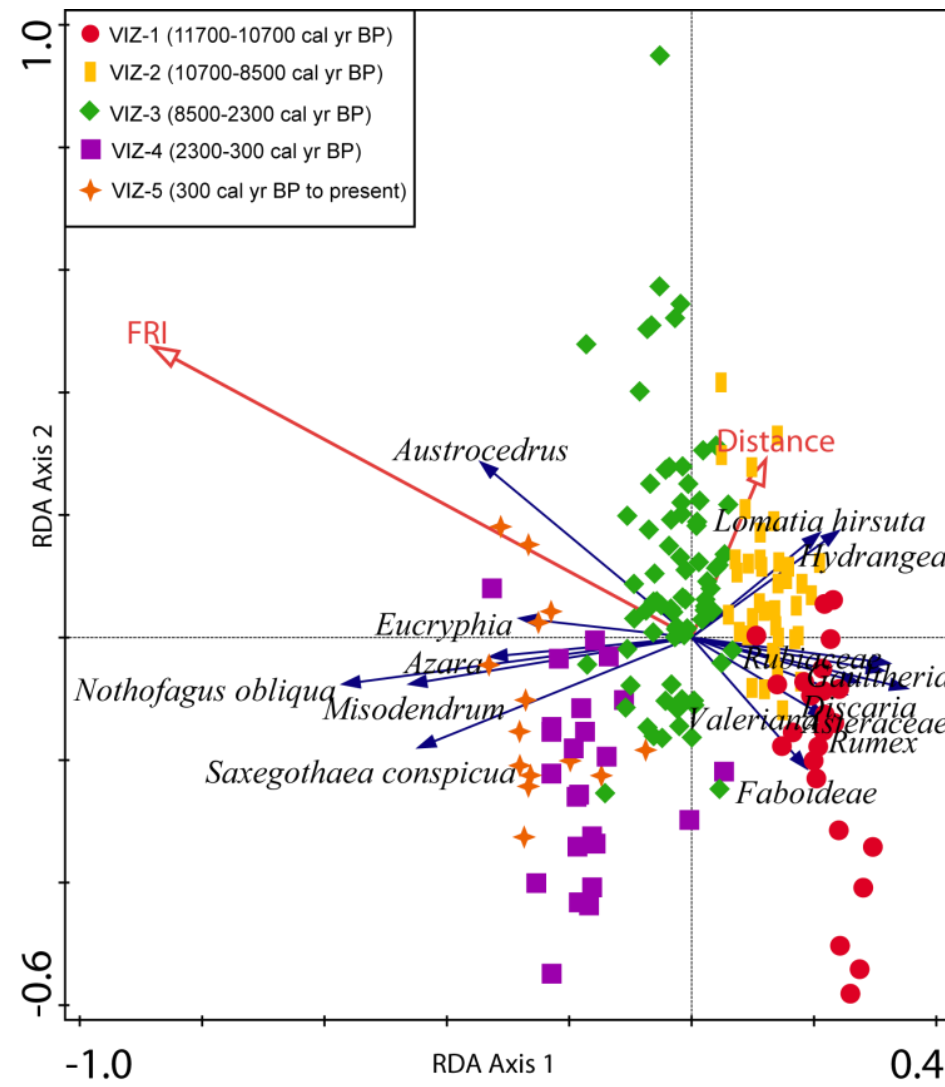

Figure 24. Redundancy analysis (RDA) biplot of samples/species/environmental variables of Lake Vizcacha. The shows the 15 best fitting species indicated by the ordination analysis. Notice only the most significant variables according to the analysis are shown in the RDA.

The variables distance and decay explained less than $5 \%$ of the variation (see Table 9). Nevertheless, based on the $p$-value the variable distance is statistically significant in explaining the variability of the data set in this analysis. The variable distance shows a positive correlation with Lomatia hirsuta and Hydrangea and is more related to samples of the transition Early-Mid Holocene (green 
rhomboids and yellow rectangle in Figure 24). The variable decay is not shown in the RDA plot since explain less than $1 \%$ of the variation. More insights on how tephra deposition has influenced the vegetation can be obtained from when evaluating the pollen concentration (Figure 25) and pollen percentage (Table 10).

Table 9. Simple effect derived from the RDA

\begin{tabular}{|c|c|c|c|c|}
\hline Variable & Explained \% & Pseudo-F & $p$ & $p$ (adjusted) \\
\hline Fire return interval & 10.4 & 20.0 & 0.002 & 0.008 \\
\hline $\begin{array}{l}\text { Charcoal } \\
\text { Accumulation rate }\end{array}$ & 5.9 & 10.8 & 0.002 & 0.008 \\
\hline Distance & 3.4 & 6.1 & 0.002 & 0.01 \\
\hline Fire frequency & 1.6 & 2.8 & 0.02 & 0.08 \\
\hline Decay & 0.4 & 0.7 & 0.656 & 1 \\
\hline Fire Magnitude & 0.2 & 0.4 & 0.962 & 1 \\
\hline
\end{tabular}

Table 10. Schematic representation by arrows of the decrease/increase in the percentage of selected taxa in the sample right after the occurrence of a tephra relative to the prior sample. Tephra thickness is shown in centimetres. Equal sign indicates no change in percentage.

\begin{tabular}{|c|c|c|c|c|c|}
\hline Age (cal. yr BP) & $\begin{array}{l}\text { Tephra } \\
\text { thickness } \\
\text { (cm) }\end{array}$ & N. dombeyi & N. obliqua & Misodendrum & Poaceae \\
\hline 900 & 10 & $\uparrow$ & $\downarrow$ & $\downarrow$ & $\downarrow$ \\
\hline 1700 & 20 & $\downarrow$ & $\uparrow$ & $=$ & $\downarrow$ \\
\hline 2100 & 37 & $\uparrow$ & $\downarrow$ & $\uparrow$ & $\uparrow$ \\
\hline 7900 & 11 & $\uparrow$ & $\downarrow$ & $\uparrow$ & $\downarrow$ \\
\hline 10300 & 31 & $\downarrow$ & $=$ & $\downarrow$ & $\uparrow$ \\
\hline 10600 & 52 & $\uparrow$ & $\uparrow$ & $\downarrow$ & $\downarrow$ \\
\hline 11500 & 14 & $\uparrow$ & $=$ & $\uparrow$ & $\downarrow$ \\
\hline
\end{tabular}




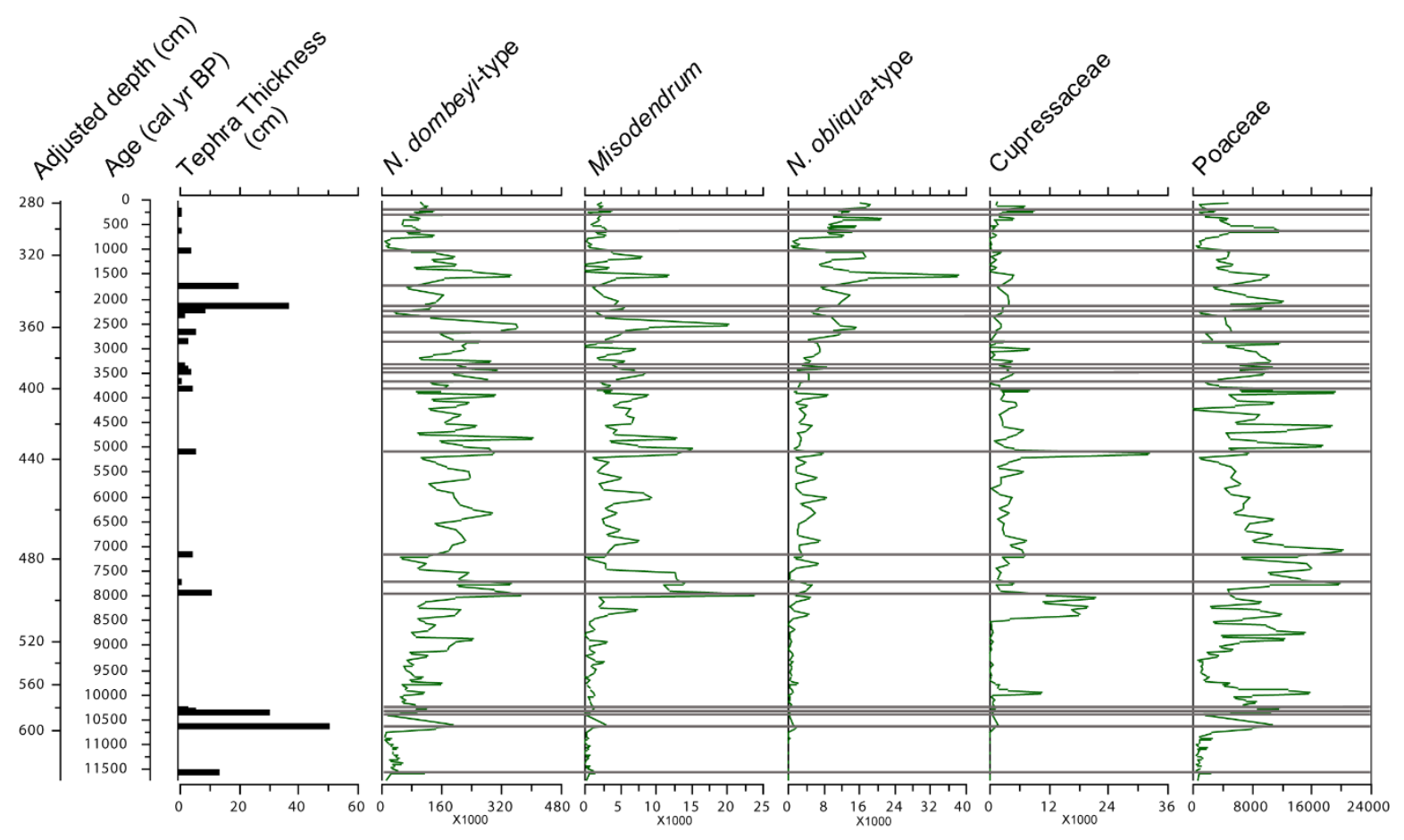

Figure 25. Pollen concentration diagram of selected taxa. On the left side of the diagram, tephra layers identified on Vizcacha core are represented as bars. Grey lines represent the location of the tephra.

Overall, pollen concentration of $N$. obliqua-type and Cupressaceae diminish after a tephra deposit, independently of the thickness of the layer. Nevertheless, after the deposition of a $52 \mathrm{~cm}$ thick ash layer of around 10500 cal. yr BP, Cupressaceae exhibit an increase in their concentration. The concentration of Poaceae increases after the deposition of the thickest tephra layers while its concentration drops after the deposition of thinner layers. Misodendrum concentration diminish with the deposition of ash layers of 52 and $31 \mathrm{~cm}$ thick (10600 and $10300 \mathrm{cal}$. yr BP respectively). However, this pattern changes since Misodendrum show a rise in its concentration after $37 \mathrm{~cm}$ of tephra. $N$. dombeyi-type shows an increase in its concentration after the deposition of the major tephra layers.

Among the fire variables tested, fire return interval (FRI) is the most important, explaining $10 \%$ of the variation. As the RDA plot shows, there is a positive correlation between FRI and Austrocedrus, and related with samples of the last zone VIZ-5 (300 cal. yr BP to present). In addition, the analysis indicates a negative correlation of FRI with steppe taxa indicators which characterize the samples from the Early Holocene. 


\subsubsection{Fire record}

The past fire regime recorded in the Vizcacha core is shown in Figure 26. The same zone division used for pollen assemblages was applied to the fire record with the purpose to compare possible changes in vegetation composition due to fire. Throughout the record, the signal-to-noise index $(\mathrm{SNI})$ is $>3$, indicating that the charcoal peak signal obtained from the time series analysis is well separated from noise (Kelly et al., 2011). Nevertheless, values < 3 occur intermittently between 6600-6400 cal. yr BP and 3000-2800 cal. yr BP.

Zone VIZ-1 (11700-10700 cal. yr BP) indicate a low CHAR between 11700 and 11200 cal. yr BP with an average of 0.4 particles $\mathrm{cm}^{-2}$ year-1 and a later increment with 2.5 particles $\mathrm{cm}^{-2}$ year-1 between 11200 and 10700 cal. yr BP. Fire frequency during the time comprises in zone VIZ-1 decrease from 3.5 to 1.1 fires $1000 \mathrm{yr}^{-1}$ and only 2 fire episodes detected. Zone VIZ-2 (10700-8500 cal. yr BP) is characterized by a CHAR of 2.5 particles $\mathrm{cm}^{-2}$ year ${ }^{-1}$ until 10600 cal. yr BP dropping to 0.09 particles $\mathrm{cm}^{-2}$ year $^{-1}$ until 10200 cal. yr BP. The highest values in CHAR within this zone reach 5.5 particles $\mathrm{cm}^{-}$ ${ }^{2} \mathrm{yr}^{-1}$ at 10100 cal. yr BP. Afterwards, CHAR values fluctuate between 0.1 and 2.5 particles $\mathrm{cm}^{-2} \mathrm{yr}^{-1}$. Fire frequency exhibit a gradual increase with a maximum of 4.3 fires $1000 \mathrm{yr}^{-1}$ around $9300-8800$ cal. $\mathrm{yr} \mathrm{BP}$. By the end of this zone, fire frequency is 3.3 fires $1000 \mathrm{yr}^{-1}$. VIZ-2 zone comprises 7 fires episodes with the highest magnitude at 10200 and at 8900 cal. yr BP, concomitant with peaks in CHAR values. Fire return interval (years per fire, $\mathrm{yr} \mathrm{fire}^{-1}$ ) in zone $\mathrm{VIZ}-2$ fluctuate between 100 and 200 yr fire ${ }^{-1}$. 


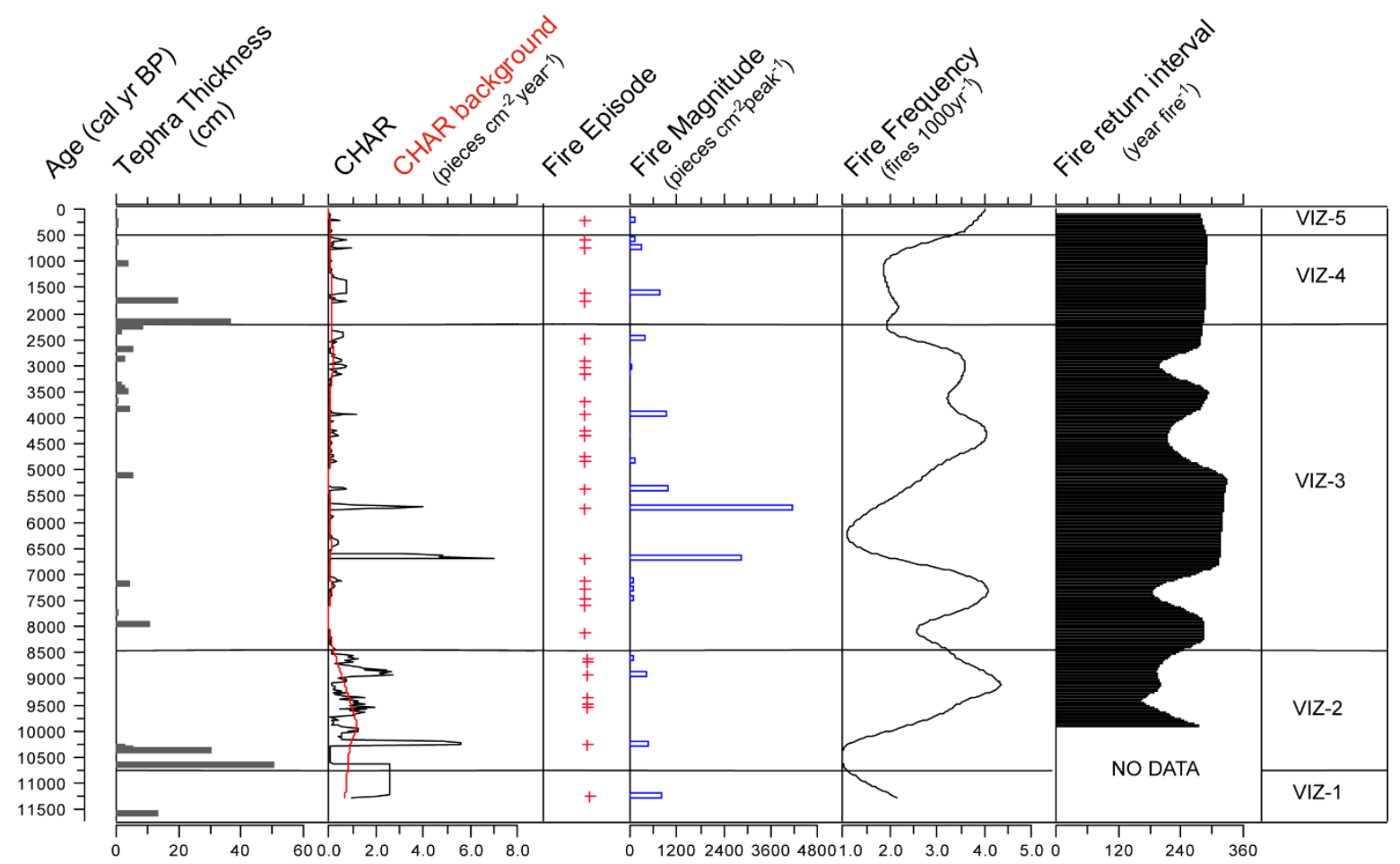

Figure 26. Holocene fire characteristic reconstructed from Vizcacha core. Charcoal accumulation rates (CHAR), fire episodes, fire magnitude, fire frequency, and fire return interval and their units are indicated. Zones were defined based on palynological zones.

Zone VIZ-3 (8500-2300 cal. yr BP) is mainly characterized by low values in CHAR (0.2-0.1 particles $\mathrm{cm}^{-2} \mathrm{yr}^{-1}$ ) except for two large peaks at 6600 and 5700 cal. yr BP. Those peaks are related with fires of high magnitude. Fire frequency is high (4.1 fires $1000 \mathrm{yr}^{-1}$ ) between 7400-7100 cal. yr BP and 4400-4100 cal. yr BP, while the lowest frequency (1.1 fires $1000 \mathrm{yr}^{-1}$ ) occurs between 6400-5700 cal. yr BP. Fire return interval vary between 100 and $300 \mathrm{yr} \mathrm{fire}^{-1}$. In total, 10 fire episodes were identified.

Zone VIZ-4 (2300-300 cal. yr BP) comprises CHAR values between 0 to 0.9 particles $\mathrm{cm}^{-1} \mathrm{yr}^{-1}$. Fire frequency is lower in comparison with the prior zone with a maximum of 3.7 fires $1000 \mathrm{yr}^{-1}$. The maximum magnitude in fire occurs at $1600 \mathrm{cal}$. yr BP. Four fire episodes were detected, and fire return interval is around $200 \mathrm{yr} \mathrm{fire}^{-1}$. From $300 \mathrm{cal}$. yr BP to present century, only one fire episode was identified. On the other hand, fire frequency increases from 3 to 4 fires $1000 \mathrm{yr}^{-1}$ and CHAR values barely reach 0.5 particles $\mathrm{cm}^{-2} \mathrm{yr}^{-1}$. 


\subsection{Discussion}

\subsubsection{Vegetation reconstruction}

\section{Early Holocene}

The shifts in sediment composition of the core between 11700 and 8500 cal. yr BP indicate that the Early Holocene was characterized by alternate wet and dry conditions. Sediment composition and pollen content document the persistence of a Cyperaceae dominated wetland until $10700 \mathrm{cal}$. yr BP (Figure 21). Given the current vegetation around Lake Vizcacha it could be that individuals of Nothofagus antarctica were present. Nothofagus antarctica is a species that tolerate cold and dry environments; and occurs also in swampy areas (Amigo and Rodríguez, 2011; Donoso, 2013). The development of a wetland in the basin that is currently a $2.5 \mathrm{~m}$ depth lake, containing almost $1 \mathrm{~m}$ of peat and tephra indicates reduced precipitation during the first 1400 years of the Holocene. Markgraf and Bianchi (1999) interpret the increase of grasses in sites located east of Andes between 11000 and 10000 cal. yr BP as either an increase in temperature and or a decrease in precipitation. Moreover, Abarzúa (2013) and Abarzúa et al. (2014) analysing site located west Andes (395) infer that the high percentage of Nothofagus obliqua-type, Eucryphia/Caldcluvia, Weinmannia trichosperma and high percentage of charcoal particles suggest warm and dry climatic conditions during the Early Holocene. Therefore, the interpretation of a dry period between 11700 and 10700 cal. yr BP is concomitant with other studies in the region.

An abrupt decrease in the percentage of Cyperaceae and the appearance of Myriophyllum at 10700 cal. yr BP suggest an increase in precipitation which allowed the development of a shallow lake that persisted until $9700 \mathrm{cal}$. yr BP. The shift from peat to gyttja sediment during this period support this interpretation (see Figure 21). In addition, a slight increase in the percentage of Cupressaceae (peak of $6 \%$ at 9900 cal. yr BP) might be the result of the increase in precipitation likely during the growing season, allowing the presence of some individuals of Austrocedrus chilensis (Iglesias et al., 2011). Nevertheless, the influence of fire in the establishment and dynamic of this conifer might have played a key role in its development.

This humid interval is characterized also by a high percentage of Poaceae. As mentioned before, in west and east Andes the Early Holocene is considered as a dry and warm period. De Batist et al. (2008) indicate a replacement of Nothofagus dombeyi-type forest by Nothofagus obliqua-type and other thermophilous taxa in the Chilean Lake District region. Likely, despite the documented 
increase in precipitation, warm conditions prevailed and may have affected Nothofagus dombeyitype forest, leading probably to a more open forest, triggering either the colonization of the bamboo Chusquea culeou in open areas within the forest or the presence of patches of grasslands at the mountains around Lake Vizcacha.

The period between 9700 and 8500 cal. yr BP features a rise in the abundance of Cyperaceae and the disappearance of Myriophyllum and the presence of a peat section for this interval. All these findings suggest a decrease in precipitation and a tendency to the development of a wetland. However, the decrease in the water table was not similar to the first wetland stage (11700-10700 cal. yr BP). This because the percentage of Cyperaceae did not present the same values as those reported during the first dry stage (see Figure 21). Therefore, the decline in precipitation was slight in comparison with the period $11700-10700$ cal. yr BP.

\section{Mid Holocene}

A gyttja-dominate section coupled with a decline in Cyperaceae and the intermittent presence of Potamogeton and the green algae Botryococcus and Pediastrum characterize the period between 8500 and 4000 cal. yr BP leading to the interpretation of a permanent shallow lake. The observed increment in Glomus percentage may be indicating active soil erosion processes in the catchment area (Musotto et al., 2012). Cook (2009) analysing Australian lakes concluded that the presence of Glomus suggests soil erosion in the basin as a consequence of increased rainfall delivering greater amounts of sediment to the lake. Likely, heavy rainfall during the Mid-Holocene triggered an influx of allochthonous material into Lake Vizcacha explaining the increase of Glomus.

The percentage of Nothofagus dombeyi-type remains above the $83 \%$ mean during the entire period. Markgraf et al. (2002) analysed pollen records from west and east Andes at $40^{\circ} \mathrm{S}$, and they observed a rise in the percentage of $N$. dombeyi-type and a decline in Eucryphia/Caldcluvia and steppe elements at west and east of Andes respectively. They infer a regional increase in summer precipitation and a decline in summer and winter temperatures during the Mid-Holocene. A similar pattern in observed in Vizcacha record, with low percentages in shrubs elements, a decline in Poaceae percentage and the stable presence of $N$. dombeyi-type forest.

On the other hand, between 8500 and 8000 cal. yr BP there is a decline in the percentage of Nothofagus dombeyi-type and a rise in Cupressaceae. The topmost samples of Vizcacha documented $<1 \%$ of Cupressaceae which represent the upwind transport of pollen from 
Austrocedrus chilensis populations located behind the mountains located at the north of Lake Vizcacha. The percentage of Cupressaceae documented at the beginning of the Mid-Holocene is 15\%. Comparing with other records in Argentina, Iglesias and Whitlock (2014) observed in seven lake sediment records $\left(41^{\circ}\right.$ to $\left.43^{\circ} \mathrm{S}\right)$ a common pattern of increase in the percentage of Cupressaceae during the Mid-Holocene, attributed to a regional expansion of Austrocedrus triggered by an increase in effective moisture. Markgraf et al. (1981) states that Austrocedrus has a restricted pollen dispersal therefore, percentages $>10 \%$ might indicate the presence of small populations of this conifer. Given all this background, it is possible to interpret that a small population of $A$. chilensis was present nearby Lake Vizcacha.

The Mid-Holocene also documented a rise in the percentage of Misodendrum. According to TerceroBucardo and Rovere (2010), the genus Misodendrum comprises 8 species that infest specifically Nothofagus species along their entire distribution range $\left(33-56^{\circ} \mathrm{S}\right)$. Around Lake Vizcacha five species of Nothofagus occur, being Nothofagus pumilio, N. antarctica, and N. dombeyi infested mainly by Misodendrum punctulatum (Tercero-Bucardo and Rovere, 2010). Markgraf et al. (2002) based in modern pollen-rain samples $\left(39^{\circ}\right.$ to $\left.43^{\circ} \mathrm{S}\right)$ argues that high percentages of Misodendrum (> $10 \%)$ are found in sites where the Nothofagus forest is less dense. This leads to the interpretation that the Nothofagus dombeyi-type forest next to Vizcacha lake was characterized by a closed canopy as the percentage of Misodendrum features a mean of $\sim 2 \%$.

\section{Late Holocene}

The Late Holocene has been described as a period where the current climate conditions began to establish in the region (Lamy et al., 2010; Markgraf et al., 2009) as well as the modern state of the El Niño Southern Oscillation system, implying variations in precipitation seasonality (Lamy et al., 2001). In the Vizcacha record, at ca. 2200 cal. yr BP Nothofagus dombeyi-type percentage decline while the percentage of Cupressaceae and Nothofagus obliqua-type increase. This assemblage might be attributed to a warming pulse during the Late Holocene which triggered a decline in effective moisture (related to precipitation), affecting probably Nothofagus dombeyi (Echeverría et al., 2014). On the other hand, drought-tolerant taxa such as A. chilensis and N. obliqua/N. alpina likely were capable to persist during this warm phase.

The presence of Nothofagus obliqua-type in pollen records located at the Central Valley of Chile and west slopes of the Andes between $39^{\circ}$ and $40^{\circ}$ S (Abarzúa, 2013; Abrazúa et al., 2014; de Batist et 
al., 2008; Vargas-Ramírez et al., 2008) has been used as an indicator of warmer climatic conditions. A noticeable increase in the percentage of this pollen type in the Vizcacha record during the Late Holocene is observed which might be interpreted as the establishment of the modern population of both Nothofagus obliqua and Nothofagus alpina within the Lácar basin. Here, Nothofagus obliqua is almost present in all the slopes of the mountain oriented towards the lake (see Figure 18) but at low elevations (650 to $800 \mathrm{~m}$ a.s.l.). Nothofagus alpina is mainly located in the longitudinally oriented valleys between 800 and 1000 m a.s.I. (Sabatier et al., 2011). Nevertheless, it may occur also at $650 \mathrm{~m}$ a.s.l. in humid slopes i.e. south-east aspect (Donoso, 2013). Based on the position of Lake Vizcacha and the elevation (1095 m a.s.l.), probably Nothofagus alpina is contributing the most to the Nothofagus obliqua pollen type.

The Vizcacha record also indicates high percentages of aquatic taxa such as Myriophyllum and Potamogeton as well peaks in Botryococcus and Pediastrum algae. These green algae have been used as indicator of eutrophication (Martínez et al., 2008; van Geel et al., 1980). Likely climatic conditions coupled with oscillation in the water table of the lake may lead to the erosion of the edge of the lake delivering nutrients. For the last 200 years of the record, is observed an increase in the percentage of Glomus sp, which suggest soil erosion. It is known that Nothofagus alpina and Nothofagus obliqua were extensively extracted for commercial purposes and due to those activities, the populations of both species diminished substantially. The pollen diagram shows a decrease in the percentage of Nothofagus obliqua-type which might reflect the reduction in the populations of both deciduous trees. Additionally, the extensive clear-cutting might have contributed to the erosion and eutrophication processes in Lake Vizcacha, together with animal husbandry. The presence of Rumex acetosella and Plantago lanceolata supports this hypothesis.

\subsubsection{Disturbance regimes and their effects on the local vegetation dynamics} nearby Lake Vizcacha

Several tephra layers of different thicknesses were identified in the Vizcacha core. Their presence along the entire core is an indicator of the constant volcanic activity in the region during the Holocene (Figure 20 and 27). Explosive Holocene eruptions in the segment of the Andean Central and Southern Volcanic Zone are documented in Naranjo and Stern (2004), Fontijn et al. (2014) and Naranjo et al. (2017). Given the frequent deposition of ash, one would expect some influence of ash deposition on the vegetation. The RDA results (Figure 24) indicate no statistically significant effect

of ash deposition for the variable decay, which represents an exponential decrease of the influence 
of ash deposition on vegetation composition with time. Nevertheless, according to the $p$-value, the variable distance (linear decrease of the influence of ash deposition) indicate a significant influence of this variable on vegetation composition (Table 9). As it is shown in Figure 24, the variable Distance is positively correlated with Lomatia hirsuta and Hydrangea. This relationship may indicate a gradual increase of both taxa after ash deposition, suggesting likely a tendency to the development of thickets of Lomatia after ash deposition due to the creation of small open areas within the canopy by the possible damage of tree branches. On the other hand, Hydrangea is a liana characteristic of the forest in this region (Jimenez-Castillo and Lusk, 2009) and might be an indicator of a more open canopy after disturbance.

About the changes in the concentration of Nothofagus dombeyi-type (which include N. pumilio, N. dombeyi, and $N$. antarctica) after tephra deposition, the results show a random pattern suggesting that shifts in pollen concentration could be independent of the ash deposition. Swanson et al. (2013) report canopy loading by accumulated airfall tephra and partial loss of the foliage. The author also highlighted the fact that the features of the species (age, leave morphology, species, etc) determine the effects of ash accumulation on the canopy. Around Lake Vizcacha Nothofagus pumilio and Nothofagus antarctica are deciduous trees and perhaps, some of the volcanic eruptions could have occurred during the fall/winter, when both species already lost the leaves and therefore, accumulation of ash on the foliage is almost null. This interpretation would however not work for the evergreen Nothofagus dombeyi.

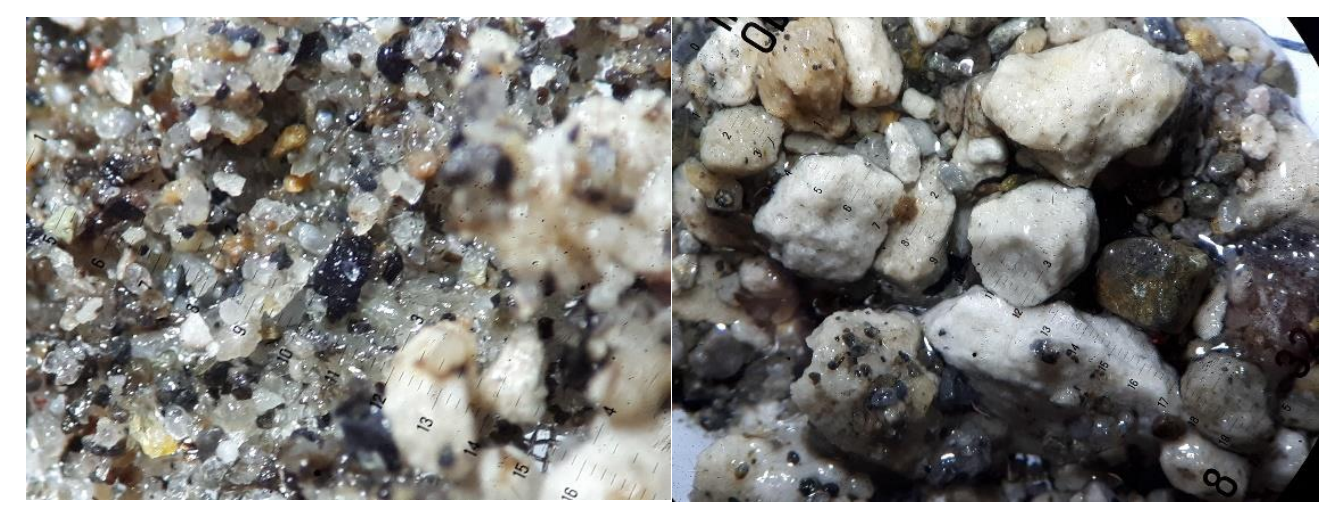

Figure 27. Images taken under the stereomicroscope of the particles that composed the tephra layers described in Table 7 between $716-813 \mathrm{~cm}$ (10200-10700 cal. yr BP). See figure 20. Notice the pumice pebbles shown at the right.

Certainly, the predisposition of the vegetation i.e. the previous conditions of the vegetation before the eruption, explain partially its response to a given disturbance agent. In addition, the climatic conditions (season) at the time of the eruption, the topography (valleys, slopes, hills) and the 
morphological adaptations and regeneration strategies are variables that should be considered at the time of interpreting the influence of tephra fall on the vegetation.

To sum up, the deposition of tephra layers might not have triggered substantive changes in the local vegetation recorded in Lake Vizcacha. Moreover, the vegetation response to ash deposition seems to be somehow random, probably as a result of certain conditions like the season of eruption, the age of the species, and their biological adaptation to disturbance. Nevertheless, a minor reduction in the palynological richness after the deposition of $>50 \mathrm{~cm}$ of tephra has been observed, as well as a decline in the concentration of Poaceae and Misodendrum, likely as a response to burial process, especially in grasses. On the other hand, millennial and/or sub-millennial climatic variations would be influencing primarily the changes in the local vegetation. Since volcanic eruptions are unpredictable (Maes et al., 2016) and independent of climatic forces, perhaps other disturbances agents strengthened or attenuated by climate could have played a major role on the vegetation dynamics.

The presence of macro charcoal particles recovered from Vizcacha core attests to the local occurrence of fire. The results obtained from the time series analysis presented in Figure 26 indicate an Early Holocene characterized by fires of high frequency and moderate magnitude, as well as high $\mathrm{CHAR}$ values. High fire activity during the Early Holocene is also documented by Iglesias and Whitlock (2014) in sites located between $41^{\circ}$ and $43^{\circ} \mathrm{S}$ in Argentina. High CHAR values for the early Holocene are also observed in the record from Mallín Pollux at $45^{\circ} \mathrm{S}$ (Coyhaique, Chile) interpreted as a consequence of higher summers than today (Markgraf et al., 2007). Here the fires were of moderate magnitude and high frequency. At west Andes, between $40^{\circ}$ and $44^{\circ} \mathrm{S}$ fires records show high $\mathrm{CHAR}$ values during the Early Holocene, characterized by fires of high magnitude, concomitant with the inferred dry and warm period in the region (Moreno et al., 2018; Moreno and Videla, 2016).

The regional peak in fire events during the Early Holocene has been attributed to the dry and warm conditions. The decrease in effective moisture promoted dry fuel and allowing the continuity and spread of fire affecting the local vegetation nearby Lake Vizcacha. Moreover, the interpretation of the local occurrence of fires is supported by the presence of Gelasinospora, a fungal spore that develops in charred organic material (van Geel and Aptroot, 2006).

A significant decrease in the concentration of Poaceae together with a slight decline N. dombeyitype occur between 9700-8700 cal. yr BP, being concomitant with a maximum peak in the fire frequency and low magnitude fires (Figure 30). Likely, high biomass production during the growing 
season of the prior period (especially grasses) contributed with enough fuel to support fires affecting probably tall shrublands of Nothofagus antarctica, as well as the herbaceous layer. Relatively high CHAR values for the Early Holocene indicate moderate biomass burning (Iglesias and Whitlock, 2014; Whitlock et al., 2006).

A rise in the percentage of Cupressaceae (Austrocedrus chilensis) between 10000-9700 cal. yr BP occurs during periods of long fire-free intervals and low fire magnitude. The same pattern is observed later at the beginning of the Mid-Holocene between 8500 and 8000 cal. yr BP, parallel to a decline in the concentration of $N$. dombeyi-type and Poaceae. The RDA analysis shows a positive correlation between FRI (fire return interval) and Cupressaceae (Figure 24) and a statistically significant influence of this fire component on the variability of the data $(p=0.002)$. The long firereturn interval at $8500 \mathrm{cal}$. yr BP coincides with the shift from dry to wet conditions inferred by the change in sediment composition of the core (see Figure 21). Under this scenario, those more humid conditions reported at the beginning of the Mid-Holocene could have prevented vegetation ignition and therefore, a decline in fire events, expressed as long fire-free intervals.

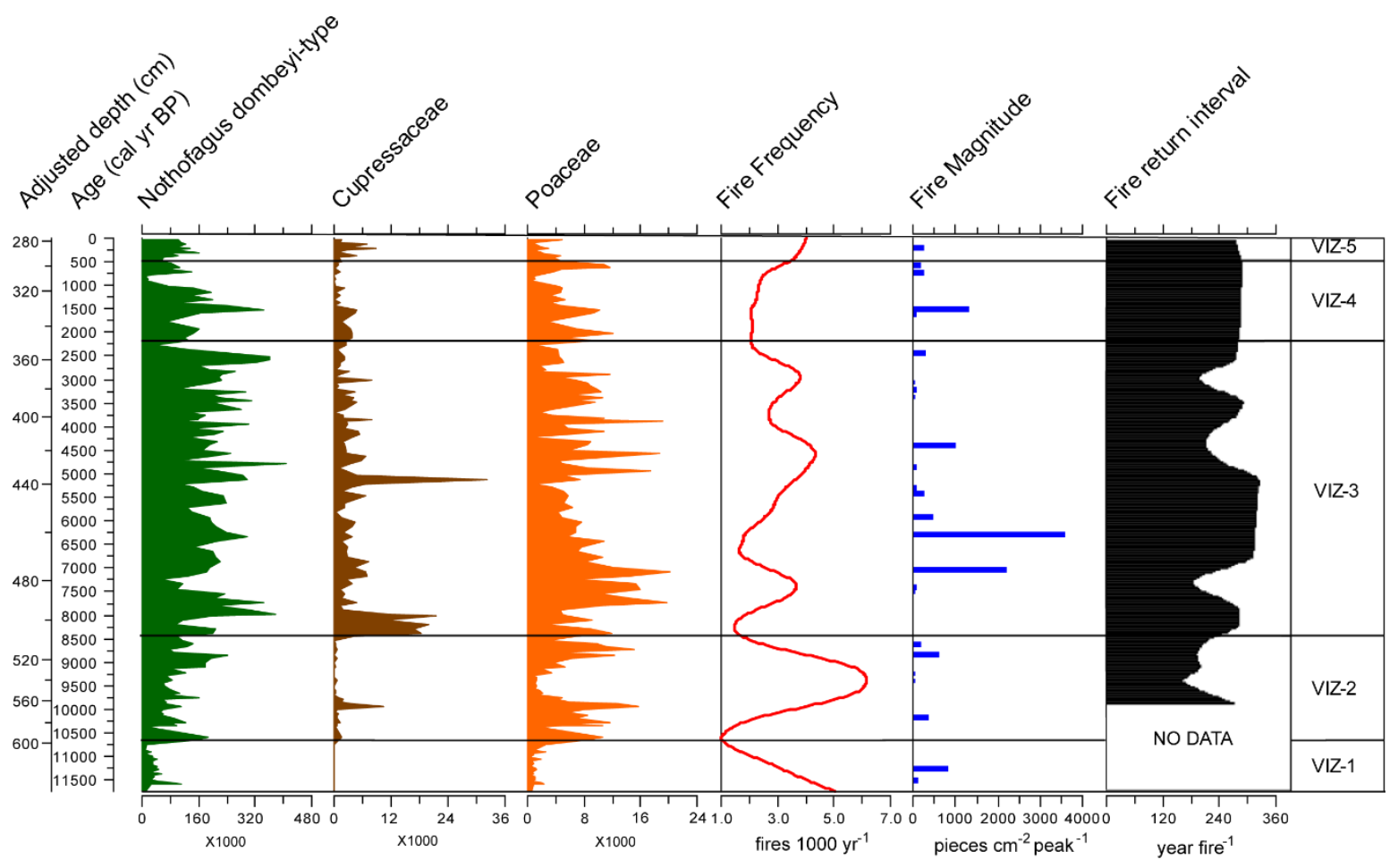

Figure 28. Fire record and pollen concentration of selected taxa from Lake Vizcacha.

The abrupt decrease in the percentage of $A$. chilensis is associated to a shift in fire return interval (300 to 180 year fire ${ }^{-1}$ ) coupled with higher-than-before fire magnitude after 8000 cal. yr BP. 
Subsequently, Poaceae shows a rapid increase simultaneous with variations in fire frequency (2-4 fires $\left.1000 \mathrm{yr}^{-1}\right)$. The maximum percentage of Poaceae between 8000 and 7500 cal. yr BP is correlated with fires of low magnitude and short fire return interval (see Figure 28), reflecting rapid fuel recovery due to the vigorous resprouting of herbaceous elements (Veblen et al., 1992). Moreno (2000) analysing a record from the Chilean Lake District interpret the increase in Poaceae as a consequence of small forest gaps created by low-severity fires allowing probably the development and spread of bamboo of the genus Chusquea. After $7000 \mathrm{cal}$. yr BP fire magnitude enhances and Poaceae concentration decline, suggesting grass burning and possible also affecting forest understory dominated by Chusquea culeou. Mid-Holocene fire regime might be related to variations in summer/winter insolation and effective moisture, with cold/wet and warm/dry intervals associated with increased importance of ENSO variability (Moreno and Videla, 2016; Whitlock et al., 2007).

A slight increase in fire frequency is observed between 4000 and 2000 cal. yr BP associated with a gradual decrease in Cupressaceae and Poaceae concentration. The last 300 cal. yr BP indicate low concentration of Poaceae and $N$. dombeyi type whereas Cupressaceae concentration is higher than before (500 to 10000 grains $/ \mathrm{cm}^{3}$ ). Veblen and Lorenz (1988) compared photographic documentation of the changes in Austrocedrus chilensis populations around Lake Lácar between 1896 to 1985 , and they observed a change from sparse woodland to the dense forest of $A$. chilensis as well as increased density of $N$. obliqua and $N$. dombeyi on mesic south aspect. Most of the changes observed in the vegetation according to the authors is attributed to past forest burning. During the Late Holocene $N$. obliqua-type ( $N$. alpina and/or $N$. obliqua) became abundant documenting the expansion of N. alpina and/or N. obliqua populations around the Lácar basin. Both species possess a relatively thick bark (Donoso, 2013) and exhibit active resprouting after being cut or burned (Veblen et al., 1996). Individuals of $N$. obliqua have been observed in relatively open sites with evidence of fire (scars fires) indicating the ability of this taxon to survive surface fires (Veblen et al., 2003). In high elevation areas and south-facing slopes (like the dominant topography around Lake Vizcacha) Nothofagus alpina and Nothofagus dombeyi coexist. Here, usually fires are stand replacing (Veblen et al., 2003).

The RDA analysis shows a positive correlation between fire magnitude and human indicator taxa such as Rumex acetosella, Plantago lanceolata, and Pinus (no shown here). Albeit the magnitude of the fires is not an important variable in explaining changes in vegetation composition, certainly the 
slight increase in fire frequency during the last six centuries might be attributed to anthropogenic causes. On the other hand, the climatic conditions associated with El Niño Southern Oscillation have contributed to the changes in rainfall variability during the Late Holocene (De Batist et al., 2007; Fletcher and Moreno, 2012; Lamy et al., 2001; Montencinos and Aceituno, 2003) promoting for example arid conditions (La Niña events) that enhanced fire occurrence (Iglesias et al., 2012; Nanavati et al., 2019; Whitlock et al., 2007).

\subsection{Conclusions}

The changes in vegetation throughout the Holocene documented in Lake Vizcacha are mainly attributed to variations in the abundance of Poaceae, Cupressaceae, Nothofagus dombeyi-type and Nothofagus obliqua-type. The Early Holocene was characterized by the abundance in herbs and shrubs, suggesting a more open-than-today Nothofagus forest. Decrease in effective moisture due to a reduction in precipitation was inferred by the peat layers identified, indicating lower-than-today water levels which allowed the expansion of wetland taxa such as Cyperaceae. On the other hand, moderate values in CHAR suggest moderate fires during the Early Holocene. Fires may have affected tall shrubs of Nothofagus antarctica as well as the herbaceous layer during this period. Major changes in vegetation composition attributed to volcanic ash depositions were discarded, although it was observed a slight decline in the percentage and concentration of herbaceous elements after the depositions of tephra layers $>10 \mathrm{~cm}$ thick. Even so, the RDA analysis indicated no statistically significant influence of ash deposition on vegetation composition.

The Mid-Holocene was marked by the presence of Austrocedrus chilensis and wetter than before conditions. Long fire-free periods allowed the occurrence of this conifer for around 500 years. Nevertheless, an increase in fire magnitude and shorter fire-free periods led to a remarkable diminish in Austrocedrus whilst Nothofagus become abundant. Undoubtedly, climatic forces mainly associated with the onset of ENSO during the Mid-Holocene might influence the fire regime.

The last 2000 cal. yr BP are characterized by the rise in the abundance of pollen from Nothofagus obliqua/Nothofagus alpina, indicating the establishment of both species during the Late Holocene in the Lácar basin. It is inferred that the establishment of the current climatic conditions (dry summers and rainy winters) allowed the persistence and development of both species. Fire frequency was lower in comparison with the Mid-Holocene, however, fire frequency increased during the last six centuries and the time between fires (fire return interval) became shorter. The 
post-fire establishment in north/east-facing slopes of the Lácar basin of Austrocedrus chilensis was documented in the upper zone of the pollen diagram. The extensive extraction of Nothofagus alpina and Nothofagus obliqua for commercial purposes that resulted in the degradation of their population, was detected in the pollen diagram by a decline in the percentage of Nothofagus obliqua-type.

Overall, the results in this work contribute to a better understanding of the vegetation dynamics during the last 11700 cal. yr BP around the Lácar basin, filling an empty gap regarding palynological records in northern Patagonia Argentina at $40^{\circ} \mathrm{S} 71^{\circ} \mathrm{W}$. This work is one of the first in showing the presence of Nothofagus obliqua-type nearby the Lácar basin since 11000 cal. yr BP with a major expansion after 3000 cal. yr BP. Additionally, this work indicates that the frequent deposition of volcanic ash seems not to play an important role in changing the vegetation.

\section{Acknowledgement}

I would like to thank the authorities of the Argentinean National Park to allow the fieldwork in the Lanín National Park. The help of the forest ranger is really appreciated. Dr. Thomas Giesecke and Dr. Sonia L. Fontana conducted the fieldwork and provided with transportation and coring. Comments from T. Giesecke and Ricardo Moreno G. during the development of this work are much appreciated.

\section{Funding}

This work was supported by my doctoral grant through CONICYT Becas Chile, and the German Research Foundation to Dr. Sonia L. Fontana FO 801/3-1 and Dr. Thomas Giesecke GI 732/9-1.

\section{Declaration}

The lacustrine sediment core obtained from Lake Vizcacha was obtained under the approval of the authorities of Argentinean National Parks, with authorization DRP $n^{\circ} 687$, and through ATM $n^{\circ}$ IF2020-09669947-APN-DTC\#APNAC 


\section{References}

Abarzúa AM, Pichincura AG, Jarpa L, Martel-Cea A, Sterken M, Vega R, Pino M (2014) Environmental responses to climatic and cultural changes over the last 26000 years in Purén-Lumaco valley $\left(38^{\circ} \mathrm{S}\right)$ in Tom D. Dillehay (ed), The Teleoscopy Polity. New York, Springer DOI:10.1007/978-3-319-031286_6

Abarzúa AM (2013) Glacial-Interglacial history of the northern margin of westerly winds in southcentral Chile $\left(35^{\circ}-39^{\circ} \mathrm{S}\right)$. Informe Final Etapa 2013. Programa FONDECYT. Comisión Nacional de Investigación Científica y Tecnológica.

Abarzúa AM, Villagrán C, Moreno PI (2004) Deglacial and postglacial climate history in east-central Isla Grande de Chiloé, southern Chile (43으). Quaternary Research 62:49-59.

Administración de Parques Nacionales (2012) Plan de Gestión Parque Nacional Lanín. Tomo I: caracterización y diagnóstico.

Amigo J, Rodríguez-Guitián MA (2011) Bioclimatic and phytosociological diagnosis of the species of the Nothofagus genus (Nothofagaceae) in South America. International Journal of Geobotanical Research 1:1-20.

Amoroso MM, Suarez ML, Daniels LD (2012) Nothofagus dombeyi regeneration in declining Austrocedrus chilensis forests: Effects of overstory mortality and climatic events. Dendrochronologia 30:105-112.

Anchorena J and Cingolani A (2002) Identifying habitat types in a disturbed area of the forest-steppe ecotone of Patagonia. Plant Ecology 158:97-112.

Azpilicueta MM, Marchelli P, Gallo LA, Umaña F et al. (2016) Zonas genéticas de Raulí y Roble Pellin en Argentina. Herramientas para la conservación y el manejo de la diversidad genética. Ediciones INTA.

Azpilicueta MM, Pastorino MJ, Puntieri J, Barbero F et al. (2014) Robles in Lagunas de Epulauquen, Argentina: previous and recent evidence of their distinctive character. Revista Chilena de Historia Natural 87:24.

Azpilicueta MM, LOZANO L, GONZÁLEZ-PEÑALBA M, GALLO LA (2007). La importancia de los estudios genéticos en la conservación y el manejo de nuestros recursos forestales. El caso del Roble estepario. Revista Presencia (INTA) 51:36-38.

Bennett KD and Willis KJ (2001) Pollen. In: Smoll JP, Birks HJB, and Last WM (eds) Tracking Environmental Change Using Lake Sediment. Volume 3 Terrestrial, Algal and Siliceous Indicators. Kluwer Academic Publishers 5-32.

Birks HJB and Line JM (1992) The use of rarefaction analysis for estimating palynological richness from Quaternary pollen-analytical data. The Holocene 2:1-10.

Birks HJB and Birks HH (1980). Quaternary Palaeoecology. Arnold, London.

Blaauw M (2010) Methods and code for 'classical' age-modelling of radiocarbon sequences. Quaternary Geochronology 5:512-518. 
Conticello L, Gandullo R, Bustamante A, Tartaglia C (1996) Fitosociología de los bosques caducifolios del norte del Departamento Lácar y su de Huiliches de la provincia de Neuquén (Argentina). Bosque 17:27-43.

Cook EJ (2009) A record of late Quaternary environments at lunette-lakes Bolac and Turangmoroke, Western Victoria, Australia, based on pollen and a range of non-pollen palynomorphs. Review of Palaeobotany and Palynology 153:185-224.

Coronato A, Martínez O, Rabassa J (2004) Glaciations in Argentine Patagonia, southern South America. Quaternary Glaciations-Extent and Chronology, Part III. Ehlers J and Gibbard PL (ed).

De Batist M, Fagel N, Loutre MF et al. (2007) A continuous Holocene record of ENSO variability in southern Chile (ENSO-CHILE). Belgian Science Policy, final report part II: global change, ecosystems and Biodiversity.

Delcourt PA, Delcourt HR (1980) Pollen preservation and Quaternary environmental history in the Southeastern United States. Palynology 4:215-231.

Dezzotti A and Sancholuz L (1991) Los bosques de Austrocedrus chilensis en Argentina: ubicación, estructura, y crecimiento. Bosque 12(2):43-52.

Diaz M, Pedrozo F, Baccala N (2000) Summer classification of Southern Hemisphere temperate lakes (Patagonia, Argentina). Research and Management 5:213-229.

Di Castri F, Hajek ER (1976) Bioclimatología de Chile. Universidad Católica de Chile Imprenta y Editorial. Santiago.

Diraison M, Cobbold PR, Rossello EA, Amos AJ (1998) Neogene dextral transpression due to oblique convergence across the Andes of northwestern Patagonia, Argentina. Journal of South American Earth Science 11(6):519-532.

Donoso C (2013) Las especies arbóreas de los bosques templados de Chile y Argentina. Autoecología. Valdivia, Chile.

Echeverría ME, Sottile GD, Mancini MV, Fontana SL (2014) Nothofagus forest dynamics and palaeoenvironmental variations during the mid and late Holocene, in southwest Patagonia. The Holocene 24(8):957-969.

Eskuche U (1999) Estudios fitososiológicos en el norte de la Patagonia. II. Los bosques de Nothofagus dombeyi. Phytocoenología 29(2):177-252.

Fletcher MS and Moreno PI (2012) Vegetation, climate and fire regime changes in the Andean region of southern Chile $\left(38^{\circ} \mathrm{S}\right)$ covaried with centennial-scale climate anomalies in the tropical Pacific over the last 1500 years. Quaternary Science Reviews 46:46-56.

Fletcher MS, Moreno PI (2012) Have the Southern Westerlies changed in a zonally symmetric manner over the last 14,000 years? A hemisphere-wide take on a controversial problem. Quaternary International 253:32-46.

Fontijn K, Machowycz SM, Rawson H, Pyle DM, Mather TA, Naranjo JA, Moreno-Roa H (2014) Late Quaternary tephrostratigraphy of southern Chile and Argentina. Quaternary Science Reviews 89:7084. 
Frugoni MC, Rabino A, Chauchard L (2005) La distribución del bosque de Nothofagus y su relación con los factores del sitio en una subcuenca de la Patagonia Andina. Actas del $3^{\circ}$ Congreso Forestal Argentino y Latinoamericano, 6-9 Septiembre 2005. Corrientes-Argentina.

Garreaud R (2009) The Andes climate and weather. Advances in Geosciences 22:3-11.

Glasser NF, Jansson KN, Harrison S, Kleman J (2008) The Glacial geomorphology and Pleistocene history of South America between $38^{\circ} \mathrm{S}$ and $56^{\circ} \mathrm{S}$. Quaternary Science Reviews 27:365-390.

González ME, Amoroso M, Lara A et al. (2014) Ecología de disturbios y su influencia en los bosques templados de Chile y Argentina. In: Donoso C, González ME, Lara A (eds) Ecología Forestal. Bases para el manejo sustentable y conservación de los bosques nativos de Chile. Ediciones UACh pp. 411502.

Grimm E (2004) Tilia and TGView 2.0 software Illinois State Museum, Research and Collextion Center, Springfield, USA. Available at https://www.tiliait.com/

Glasser NF, Jansson KN, Harrison S, Kleman J (2008) The Glacial geomorphology and Pleistocene history of South America between $38^{\circ} \mathrm{S}$ and $56^{\circ} \mathrm{S}$. Quaternary Science Reviews 27:365-390.

Havinga AJ (1967) Palynology and Pollen Preservation. Review of Palaeobotany and Palynology 2:81-98.

Heiri O, Lotter A, Lemcke G (2001) Loss on ignition as a method for estimating organic and carbonate content in sediments: reproducibility and comparability of results. Journal of Paleolimnology 25:101-110.

Heusser CJ (1971) Pollen and Spores of Chile. Arizona: University of Arizona Press.

Higuera PE, Brubaker LB, Anderson PM et al. (2009) Vegetation mediated the impacts of postglacial climatic change on fire regimes in the south-central Brooks Range, Alaska. Ecological Monographs 79(2):201-219.

Iriondo M (1989) Quaternary lakes of Argentina. Palaeogeography, Palaeoclimatology, Palaeoecology 70:81-88.

Iglesias V, Haberle SG, Holz A, Whitlock C (2018) Holocene dynamics of temperate rainforest in westcentral Patagonia. Frontiers in Ecology and Evolution 5(177):1-12. doi: 10.3389/fevo.2017.00177

Iglesias V, Quintana F, Nanavati W et al. (2016) Interpreting modern and fossil pollen data along a steep environmental gradient in northern Patagonia. The Holocene 27(7):1008-1018. DOI: $10.1177 / 0959683616678467$.

Iglesias $\mathrm{V}$ and Whitlock $\mathrm{C}$ (2014) Fire responses to postglacial climate change and human impact in northern Patagonia $\left(41^{\circ}-43^{\circ} \mathrm{S}\right)$. Proceedings of the National Academy of Science 111(51):55455554.

Iglesias V, Whitlock C, Markgraf V, Bianchi MM (2014) Postglacial history of the Patagonian forest/steppe ecotone (41-43으. Quaternary Science Reviews 94:120-135.

Iglesias V, Whitlock C, Bianchi MM, Villarosa G, Outes V (2012) Climate and local controls of longterm vegetation dynamics in northern Patagonia (Lat 41 ${ }^{\circ} \mathrm{S}$ ). Quaternary Research 78:502-512. 
Iglesias V, Whitlock C, Bianchi MM, Villarosa G, Outes V (2011) Holocene climate variability and environmental history at the Patagonian forest/steppe ecotone: Lago Mosquito (42 $29^{\prime} 37.89^{\prime \prime} \mathrm{S}$, $\left.71^{\circ} 24^{\prime} 14.57^{\prime \prime} \mathrm{W}\right)$ and Laguna del Cóndor $\left(42^{\circ} 20^{\prime} 47.22^{\prime \prime S}, 71^{\circ} 17^{\prime} 07.62^{\prime \prime} \mathrm{W}\right)$. The Holocene 22(11):1297-1307.

Iriondo M (1989) Quaternary lakes of Argentina. Palaeogeography, Palaeoclimatology, Palaeoecology 70:81-88.

Jiménez-Castillo M, Lusk CH (2009) Host infestation patterns of the massive liana Hydrangea serratifolia (Hydrangeaceae) in a Chilean temperate rainforest. Austral Ecology 34:829-834.

Juggins S (2003) C2 User Guide. Software for Ecological and Palaeoecological Data Analysis and Visualisation. University of Newcastle.

Kelly RF, Higuera PE, Barrett CM, Hu FS (2011) A signal-to-noise index to quantify the potential for peak detection in sediment-charcoal records. Quaternary Research 75:11-17.

Kitzberger T (2012) Ecotones as Complex Arenas of Disturbance, Climate, and Human Impacts: The Trans-Andean Forest-Steppe Ecotone of Northern Patagonia. In: Ecotones between Forest and Grassland. R.W. Myster (ed.) New York. Springer Science+Bussiness Media, pp 59-88. DOI 10.1007/978-1-4614-3797-0_3.

Kitzberger T, Perez A, Iglesias G, Premoli AC, Veblen TT (2000) Distribución y estado de conservación del alerce (Fitzroya cupressoides (Mol.) Johnst.) en Argentina. Bosque 21(1):79-89.

Lamy F, Kiliar R, Arz HW, Francois JP, Kaiser J, Prange M, Steinke T (2010) Holocene changes in the position and intensity of the southern westerly wind belt. Nature Geoscience 3:695-699. DOI: 10.1038/NGEO959

Lamy F, Hebbeln D, Röhl U, Wefer G (2001) Holocene rainfall variability in southern Chile: a marine record of latitudinal shifts of the Southern Westerlies. Earth and Planetary Science Letters 185:369382.

Lotter AF, Birks HJB (1993) The impact of the Laacher See Tephra on terrestrial and aquatics ecosystems in the Black Forest, southern Germany. Journal of Quaternary Science 8(3):263-276.

Maes K, Vandenbussche S, Klüser L, Kumps N, de Mazière M (2016) Vertical profiling of volcanic ash from the 2011 Puyehue Cordón Caulle eruption using IASI. Remote Sensing 8(2):103. doi: $10.3390 /$ rs 8020103

Mancini MV, Prieto AR, Paez MM, Schäbitz F (2008) Late Quaternary vegetation and climate of Patagonia. Developments in Quaternary Sciences 11:351-367.

Markgraf V, Whitlock C, Anderson RS, García A (2009) Late Quaternary vegetation and fire history in the northernmost Nothofagus forest region: Mallín Vaca Lauquen, Neuquén Province, Argentina. Journal of Quaternary Science 24(3):248-258.

Markgraf V, Bradbury JP, Schwalb A, Burns SJ et al (2003) Holocene palaeoclimates of southern Patagonia: limnological and environmental history of Lago Cardiel, Argentina. The Holocene 13:581591.

Markgraf V, Bianchi MM (1999) Paleoenvironmental changes during the last 17000 years in western Patagonia: Mallín Aguado, Province of Neuquén, Argentina. Bamberger Geographische Schriften 19:175-193. 
Markgraf V, Whitlock C, Haberle S (2007) Vegetation and fire history during the last $18,000 \mathrm{cal}$ yr B.P. in Southern Patagonia: Mallín Pollux, Coyhaique, Province Aisén $\left(45^{\circ} 41^{\prime} 30^{\prime \prime} \mathrm{S}, 71^{\circ} 50^{\prime} 30^{\prime \prime} \mathrm{W}, 640\right.$ m elevation). Palaeogeography, Palaeoclimatology, Palaeoecology 254:492-507

Markgraf V (1987) Paleoenvironmental changes at the northern limit of the Subantarctic Nothofagus forest, Lat $37^{\circ} \mathrm{S}$, Argentina. Quaternary Research 28:119-129.

Markgraf V, DÁntoni HL, Ager TA (1981) Modern pollen dispersal in Argentina. Palynology 5(1):4363.

Markgraf V and D'Antoni HL (1978) Pollen Flora of Argentina. Arizona: University of Arizona Press.

Martínez MA, Ferrer NC, Asensio MA (2008) Primer registro de algas dulceacuícolas del Paleógeno de la cuenca de Ñirihuau, Argentina: descripciones sistemáticas y análisis palinofacial. Ameghiniana (Revista de la Asociación de Paleontología Argentina) 45(4):719-735.

Montecinos A, Aceituno P (2003) Seasonality of the ENSO-related rainfall variability in Central Chile and associated circulation anomalies. Journal of Climate 16:281-296.

Montiel M, González ME, Crisafulli CM (2016) Caída de tefra y su influencia sobre la estructura y dinámica de los bosques andinos de Nothofagus en el Parque Nacional Puyehue, Chile. Anales Instituto Patagonia (Chile) 44(3):5-11.

Moreira I, Monteiro A \& Ferreira T (1999) Biology and control of Parrotfeather (Myriophyllum aquaticum) in Portugal. Ecology, Environment \& Conservation 5:171-179.

Moreno PI, Videla J, Valero-Garcés B, Alloway BV (2018) A continuous record of vegetation, fireregime and climatic changes in northwestern Patagoia spanning the last 25000 years. Quaternary Science Reviews 198:15-36.

Moreno PI, Videla J (2016) Centennial and millennial-scale hydroclimate changes in northwestern Patagonia since 16,000 yr BP. Quaternary Science Reviews 149: 326-337.

Moreno PI (2000) Climate, fire, and vegetation between about 13000 and $920014 \mathrm{C} \mathrm{yr} \mathrm{BP}$ in the Chilean Lake District. Quaternary Research 54:81-89.

Musotto LL, Bianchinotti MV, Borromei AM (2012): Pollen and fungal remains as environmental indicators in surface sediments of Isla Grande de Tierra del Fuego, southernmost Patagonia. Palynology, 36(2):162-179. DOI:10.1080/01916122.2012.662919

Nanavati WP, Whitlock C, Iglesias V, de Porras ME (2019) Postglacial vegetation, fire, and climate history along the eastern Andes, Argentina and Chile (lat. 41-55 ${ }^{\circ} \mathrm{S}$ ) Quaternary Science Reviews 207: 145-160.

Naranjo JA, Singer BS, Jicha BR, Moreno H, Lara LE (2017) Holocene tephra succession of PuyehueCordón Caulle and Antillanca/Casablanca volcanic complexes, southern Andes (40-41 $\mathrm{S}$ ). Journal of Volcanology and Geothermal Research 332:109-128.

Naranjo JA, Stern CR (2004) Holocene tephrochronology of the southernmost part $\left(42^{\circ} 30^{\prime}-45^{\circ} \mathrm{S}\right)$ of the Andean Southern Volcanic Zone. Revista Geológica de Chile 31(2):225-240.

Oksanen J, Blanchet FG, Friendly M et al. (2017) Package vegan. Community Ecological Package. 
Paredes M (2003) Caracterización genética de poblaciones de Nothofagus obliqua (Mirb.et Oerst.) y Nothofagus alpina (Poepp.et Endl.) Oerst. (=N. nervosa (Phil.) Dim. Et Mil.) mediante marcadores moleculares e isoenzimáticos. Informe Técnico Final de Proyecto. PROCISUR.

R Development Core Team (2019) R: a language and environment for statistical computing. R Foundation for Statistical Computing, Vienna, Austria Available at: www.R-project.org

Rehfeldt GE, Gallo LA (2001) Introduction of ponderosa pine and Douglas-fir to Argentina. New Forest 21:35-44.

Reimer PJ, Bard E, Bayliss A et al. (2013) IntCal13 and Marine13 radiocarbon age calibration curves, 0-50,000 years cal BP. Radiocarbon 55:1869-1887.

Rovere AE, Premoli AC, Newton AC (2002) Estado de conservación del ciprés de las Guaitecas (Pilgerodendron uviferum (Don) Florín) en Argentina. Bosque 23(1):11-19.

Sabatier Y, Azpilicueta M.A, Marchelli P et al. (2011) Distribución natural de Nothofagus alpina y Nothofagus obliqua (nothofagaceae) en Argentina, dos especies de primera importancia forestal de los bosques templados norpatagónicos. Boletín de la Sociedad Argentina de Botánica 46 (1-2):131138.

Satti, P. Mazzarino, MJ Gobbi, M Funes, F Roselli, L Fernández, H (2003) Soil N dynamics in relation to leaf litter quality and soil fertility in north-western Patagonian forests. Journal of Ecology 91:173181.

Saunders KM, Roberts SJ, Perreb B, Butz C et al. (2018) Holocene dynamics of the Southern Hemisphere westerly winds and possible links to CO2 outgassing. Nature Goescience 11:650-655. https://doi.org/10.1038/s41561-018-0186-5

Secretaría de Turismo y Desarrollo Económico (2019) Web page visite don January 2020. Available at http://www.sanmartindelosandes.gov.ar/turismo/ciudad/nuestra_historia.m

Sottile GD, Bamonte FP, Mancini MV, Bianchi MM (2012) Insights into Holocene vegetation and climate changes at the southeast of the Andes: Nothofagus forest and Patagonian steppe fire records. The Holocene 22:1309-1322.

Stevenson J and Haberle S (2005) Macro Charcoal Analysis: A modified technique used by the Department of Archaeology and Natural History.

Swanson FJ, Jones J, Crisafulli, González ME, Lara A (2016) Puyehue-Cordón Caulle eruption of 2011: tephra fall and initial forest responses in the Chilean Andes. Bosque 37(1):85-96.

Swanson FJ, Jones JA, Crisafulli CM, Lara A (2013). Effects of volcanic and hydrologic processes on forest vegetation: Chaitén Volcano, Chile. Andean Geology 40(2):359-391.

Ter Braak CJF and Smilauer P (2012) CANOCO Reference Manual and CanoDraw for Windows User's Guide: Software for Canonical Community Ordination (version 5.0). Microcomputer Power, Ithaca, NY, USA. Available at: http://www. Canoco.com/

Ter Braak CJF, Prentice IC (2004) A theory of Gradient Analysis. Advances in Ecological Research. 34:237-282. DOI 10.1016/S0065-2504(03)34003-6 
Tercero-Bucardo R, Rovere AE (2010) Patrones de dispersión de semillas y colonización de Misodendrum punctulatum (Misodendraceae) en un matorral postfuego de Nothofagus antárctica (Nothofagaceae) del noroeste de la Patagonia. Revista Chilena de Historia Natural 83:375-386.

Tyson RV (2005) Distribution of the palynomorph group: phytoplankton subgroup, chlorococcale algae. In: Sedimentary Organic Matter. Oganic facies and palynofacies, Tyson, RV (ed). Chapman and Hall, London. pp. 309-317.

Van Geel B, Aptroot A (2006) Fossil ascomycetes in Quaternary deposits. Nova Hedwigia 82(34):313-329.

van Geel B, Bohncke SJP, Dee H (1980/1981) A palaeoecological study of an upper Late Glacial and Holocene sequence from "De Borchert", The Netherlands. Review of Palaeobotany and Palynology 31:367-448.

van Geel B (1978) A palaeoecological study of Holocene peat bog sections in Germany and The Netherlands, based on the analysis of pollen, spores and macro- and microscopic remains of fungi, algae, cormophytes and animals. Review of Palaeobotany and Palynology 25:1-120.

Vargas-Ramirez L, Roche E, Gerrienne P, Hooghiemstra H (2008) A pollen-based record of late glacial-Holocene climatic variability in the southern lake district, Chile. Journal of Paleolimnology 39:197-217.

Veblen TT, Kitzberger T, Raffaele E, Lorenz DC (2003) Fire history and vegetation changes in northern Patagonia, Argentina. In: Veblen TT, Baker WL, Montenegro G, Swetnam TW (eds) Fire and Climatic change in temperate ecosystems of the Western Americas. Ecological Studies 160, Springer-Verlag, New York pp. 265-295.

Veblen TT, Donoso C, Kitzberger T, Rebertus AJ (1996) Ecology of Southern Chilean and Argentinean Nothofagus forest. In: Veblen TT, Hill RS, Read J (eds) The Ecology and Biogeography of Nothofagus Forest. Yale University Press, pp. 293-353.

Veblen TT, Armesto JJ, Burns BR, Kitzberger T, Lara A, León B, Young KR (1995) The coniferous forest of South America In: Ecosystem of the World 6: Coniferous Forest, chapter 7. Andersson FA (ed). Elsevier pp 293-317.

Veblen TT, Kitzberger T, Lara A (1992) Disturbance and forest dynamics along a transect from Andean rain forest to Patagonian shrubland. Journal of Vegetation Science 3:507-520.

Veblen TT (1989) Nothofagus regeneration in treefall gaps in northern Patagonia. Canadian Journal of Forest Research 19:365-371.

Veblen TT, Lorenz DC (1988) Recent vegetation changes along the forest/steppe ecotone of Northern Patagonia. Annals of the Association of American Geographers 78(1):93-111.

Veblen TT, Lorenz DC (1987) Post-fire stand development of Austrocedrus-Nothofagus forests in northern Patagonia. Vegetatio 71:113-126.

Viale M, Bianchi E, Cara L, Ruiz LE et al (2019) Contrasting climates at both sides of the Andes in Argentina and Chile. Frontiers in Environmental Sciences 7:69.

Villagrán C (1991) Historia de los bosques templados del sur de Chile durante el Tardiglacial y Postglacial. Revista Chilena de Historia Natural 64:447-460. 
Villagrán C (1980) Vegetationsgeschichtliche und pflanzensoziologische Untersuchungen im Vicente Pérez Rosales Nationalpark (Chile). Dessertationes Botanicae 54. Ganter Verlag K.G. Germany.

Villa-Martínez R, Moreno PI (2007) Pollen evidence for variations in the southern margin of the westerly winds in SW Patagonia over the last 12600 years. Quaternary Research 68:400-409.

Whitlock C, Moreno PI, Bartlein P (2007) Climatic controls of Holocene fire patterns in southern South America. Quaternary Research 68:28-36.

Whitlock C Bianchi MM, Bartlein PJ, Markgraf V, Marlon J, Walsh M, McCoy N (2006) Postglacial vegetation, climate, and fire history along the east side of the Andes (lat 41-42.5 $\mathrm{S}$ ), Argentina. Quaternary Research 66:187-201.

Whitlock C, Anderson RS (2003) Fire history reconstructions based on sediment records from lakes and wetlands. In Veblen TT, Baker W, Montenegro G, Swetnam (eds). Fire and climatic change in temperate ecosystems of the Western Americas. Ecological Studies 160. Springer-Verlag New York. p 3-31.

Wright HE Jr (1967) A square-rod piston sampler for lake sediments. Journal of Sedimentary Petrology 37:975-976. 
Chapter 7

Nothofagus obliqua pollen type in southern South America: A revision of palynological records and Postglacial history 


\section{Abstract}

Nothofagus obliqua and Nothofagus alpina, two southern deciduous beech species distributed in Chile and Argentina have been largely studied in terms of their genetic characterization for restoration purposes and silvicultural management programs. However, little is known about past changes in distribution and abundance of these trees for the time since the Last Glacial Maximum. This work summarizes the information contained in 30 palynological records with the presence of Nothofagus obliqua pollen type. The available diagrams have variable temporal cover with some providing information since the LGM, while others document the changes during the last 200 years. Taken together these diagrams indicate a major expansion of the Nothofagus obliqua-type forest during the Mid- and Late Holocene at both sides of the Andes. This may be the result of a temperature increase inferred for this period and / or the establishment of the current hydroclimate with moist winters and dry summers. The fragmented distribution of these trees in Argentina is caused by topographical, edaphic, and local climate conditions. Due to the high-quality of the wood, both species have been extensively used for timber production in Chile and the distribution is therefore much reduced. Additionally, the conversion of native forests for crop cultivation and animal husbandry and the introduction of exotic species such as Pinus and Eucalyptus, have resulted in the degradation of both deciduous species. This work shows that there is still a lack of vegetation reconstruction in mid-latitudes in Chile and Argentina, which might help to understand the dynamics of the Lowland Deciduous Forest before and after the LGM. This long term view is needed to gain a better understanding of the possible behaviour of both Nothofagus obliqua and Nothofagus alpina under a future climatic warming scenario.

Key words: Nothofagus obliqua, Nothofagus alpina, Chile, Argentina, Postglacial history

\subsection{Introduction}

Today, the genus Nothofagus is distributed in the southern hemisphere in south-western Chile and Argentina; New Guinea, New Caledonia, New Zealand, New Britain, and south-east Australia and Tasmania (van Steenis, 1971), comprising 42 species of evergreen and deciduous trees (Heenan and Smissen, 2013). In South America, 10 Nothofagus species are recognised (Amigo and Rodríguez, 2011; Ramirez et al., 1997), occurring over the latitudinal range from $33^{\circ} \mathrm{S}$ to $55^{\circ} \mathrm{S}$ (Donoso, 2013 ; Moreira-Muñoz, 2011). On the South America landmass, the oldest evidence of the genus was found 
in deposits from the upper Cretaceous (Campanian, circa 83 mya in Antarctica) and in deposits from the Maastrichtian (circa 70 mya) (Swenson et al., 2001).

The South American Nothofagus genus is subdivided phylogenetically into three subgenera, Nothofagus, Fuscospora, and Lophozonia (Hill and Read, 1991). The subgenus Nothofagus comprises the species Nothofagus dombeyi, N. antarctica, N. betuloides, N. pumilio, N. nitida. The subgenus Fuscospora comprise only the species Nothofagus alessandri, while the subgenus Lophozonia include the species Nothofagus glauca, N. leonii, N. alpina, and N. obliqua (Donoso, 2013; Sauquet et al., 2012; Veblen et al., 1996).

Within the Nothofagus species, the morphological characteristics of their pollen grain coupled with DNA analysis have been a key tool in establishing phylogenetic relationship between species (Heenan and Smissen, 2013; Hill and Read, 1991; Fernández et al., 2016; Sauquet et al., 2012; Wang et al., 2000). For the South American Nothofagus (Chile and Argentina) the pollen types are distinguished between Nothofagus dombeyi-type (include N. dombeyi, N. antarctica, N. pumilio, N. betuloides, N. alessandri, and N. nitida) and Nothofagus obliqua-type (include N. alpina, N. glauca, and N. obliqua) (Dettmann et al., 1990; Heusser, 1971; Markgraf and D'Antoni, 1978). Since the Nothofagus dombeyi-type includes species with a wide latitudinal distribution, this pollen type appears in most palynological records in comparison with Nothofagus obliqua-type, whose species distribution is more restricted and fragmented (Donoso et al., 1993; Sabatier et al., 2011). Undoubtedly, the similarities in the pollen morphology (dombeyi and obliqua-type) make it difficult to distinguish one species from another (Iglesias et al., 2016; Markgraf et al., 2002). Therefore, inferences about which species are contributing to the pollen type are made based on the current distribution and ecology of the species involved. On the other hand, the differentiation of certain features of the pollen grain of Nothofagus dombeyi-type has contributed for example, to a more accurate interpretation of vegetation dynamics in the Austral Nothofagus forest (Fontana and Bennett, 2012).

Many recent investigations on Nothofagus obliqua and Nothofagus alpina are focussed in their genetic characterization with phylogeographical purposes (Acosta and Premoli, 2010; Azpilicueta et al., 2009; Marchelli et al., 1998; 2007; Paredes, 2003; Vergara et al., 2011; 2013); hybridization between the species (Azpilicueta et al., 2016; Donoso et al., 1990; Marchelli et al., 2004); spatial and growth patterns (Donoso, 1988; Donoso et al., 1993; Echeverría and Lara, 2004; Puntieri et al., 2006; Sabatier et al., 2011) and site index models to quantify the productivity of a determined area with 
silvicultural purposes (Attis et al., 2005; Trincado et al., 2002). Unfortunately, few palynological records show the Nothofagus obliqua pollen type and yet, little is told about their postglacial history within their entire distribution range in southern South America.

The purpose of the present chapter is to synthetize the postglacial dynamic of Nothofagus obliquatype, through the analysis of published counts on the postglacial presence and abundance of Nothofagus obliqua-type in Chile and Argentina. This information coupled with modern geographical distribution of both Nothofagus alpina and Nothofagus obliqua might help to understand the patterns of change in the distribution of both deciduous trees since the Last Glacial Maximum.

\subsection{Environmental setting}

\subsubsection{Topography and climate of the study site}

The study area (Figure 29) corresponds to the region between ca. $33^{\circ}-42^{\circ} \mathrm{S}$ and $73^{\circ}-71^{\circ} \mathrm{W}$, extending from the Pacific Ocean in Chile to the eastern slopes of the Argentinean Andes in Argentina. Towards the south, the study area comprises part of the Patagonian territory. From a broad perspective, the relief can be distinguished from west to east into the Coastal Cordillera of Chile; the Chilean Central valley; and the Andes Cordillera and foothills. Latitudinally, the climate along the study area varies between arid in the northernmost part of the study area, to warm temperate towards the south (Kottek et al., 2006). According to Luebert and Pliscoff (2017) at a macro scale, the bioclimate in the study area is Mediterranean between $34^{\circ}$ and $37^{\circ} \mathrm{S}$, and temperate between $37^{\circ}$ and $42^{\circ} \mathrm{S}$. On the eastern Andean slopes ("Precordillera Argentina") the climate has been characterized as arid $\left(32^{\circ}-35^{\circ} \mathrm{S}\right)$ and under the influence of the Pacific highpressure cell and the low pressure system of northwestern Argentina (Mancini et al., 2004).

Precipitation is one of the main factors influencing the vegetation in the region. The presence of the Andes Cordillera alters frontal precipitation systems, producing orographic precipitation on windward slopes of the Andes (Chile) and the characteristic rain shadow precipitation on lee Andean slopes (Viale and Garreaud, 2015). On western Andes (Chile) between $34^{\circ}$ and $37^{\circ} \mathrm{S}$ the precipitation originates mainly from fronts of migratory low pressure systems within the westerlies (Fuenzalida, 1982; Viale and Nuñez, 2011). Here, only up to $5 \%$ of the total precipitation occurs during the southern summer (Marchant et al., 2007). A mean annual precipitation of $500 \mathrm{~mm}$ occurs in the 
north of the study area, including the Coastal Cordillera, and Central Valley. Areas closer to the Andes receive an average of $1000 \mathrm{~mm}$. Nevertheless, some sectors near the Andes present a mean annual precipitation about > 1000 mm (Luebert and Pliscoff, 2017, Quintana and Aceituno, 2012).

Mean annual rainfall in the study area increases latitudinally $\left(34^{\circ}\right.$ to $\left.42^{\circ} \mathrm{S}\right)$ from $500 \mathrm{~mm}$ to $3000 \mathrm{~mm}$ (Quintana and Aceituno, 2012). Precipitation is common all year around in the southern part of the study area, as a consequence of the permanent influence of mid-latitude fronts. As explained earlier, the Andes intercept the tropospheric flow (Garreaud et al., 2008) and this has an effect on the amount of precipitation on the eastern slopes of the Andes. Although at south of $35^{\circ} \mathrm{S}$ precipitation is frequent throughout the year at both sides of the Andes, the mean annual precipitation is enhanced on western slopes and reduced on eastern slopes (Viale et al., 2019). The height of the Andes decreases towards the south and the presence of east-west oriented corridors within mountains allows the eastward penetration of humid air masses and therefore, high precipitation occurs on eastern Andean slopes in Argentina, around $\sim 40^{\circ} \mathrm{S}$ (Quintana and Aceituno, 2012; Sabatier et al., 2011). The distance to the Andes explains $94 \%$ of the spatial variability of the mean annual precipitation on the eastern side of the Andes (Jobbágy et al., 1995).

The temperature in the study area is largely influenced by latitude and elevation. In the region, there is a tendency towards a decrease in the mean annual temperature from north to south. The same tendency is observed for the maximum and minimum mean annual temperature (Espinoza et al., 1979). The mean annual temperature in the Chilean part of the study area ranges between $16^{\circ}$ and $8^{\circ} \mathrm{C}$ from north to south (Luebert and Pliscoff, 2017). In the Argentinean portion of the study area, the mean monthly temperature of the warmest month (January) varies between $5^{\circ}$ and $10^{\circ} \mathrm{C}$, while the temperature of the coldest month (July) range between $0^{\circ}$ and $4^{\circ} \mathrm{C}$ (Bianchi and Cravero, 2010). Local factors such as topography and wind affect air temperature in this region resulting in local deviations from these average values (Paruelo et al., 1998).

An important phenomenon that determines the interannual variability of precipitation in the study area is El Niño Southern Oscillation (ENSO). This phenomenon is characterized by the fluctuations in temperature between the east-central Pacific Ocean and the atmosphere (Grimm and Tedeschi, 2009; Jaksic, 1998). This phenomenon comprises two phases, a cold phase known as La Niña and a warm phase called El Niño. According to Montecinos and Aceituno (2003), during El Niño, there is a tendency of above-average precipitation in winter and late spring in Chile. The opposite pattern is observed during the following summer. Anomalously dry conditions during the La Niña phase in 
winter and late spring are also documented by the authors due to a southward migration of the mid-latitude storm tracks. These anomalies in precipitation have consequences in the Argentinean Andean region. For instance, the flow of Argentinean rivers is highly linked to El Niño events. Campagnucci and Araneo (2007) observed that the summer flow of the Mendoza river exhibit values above (below) the average during El Niño (La Niña) phase.

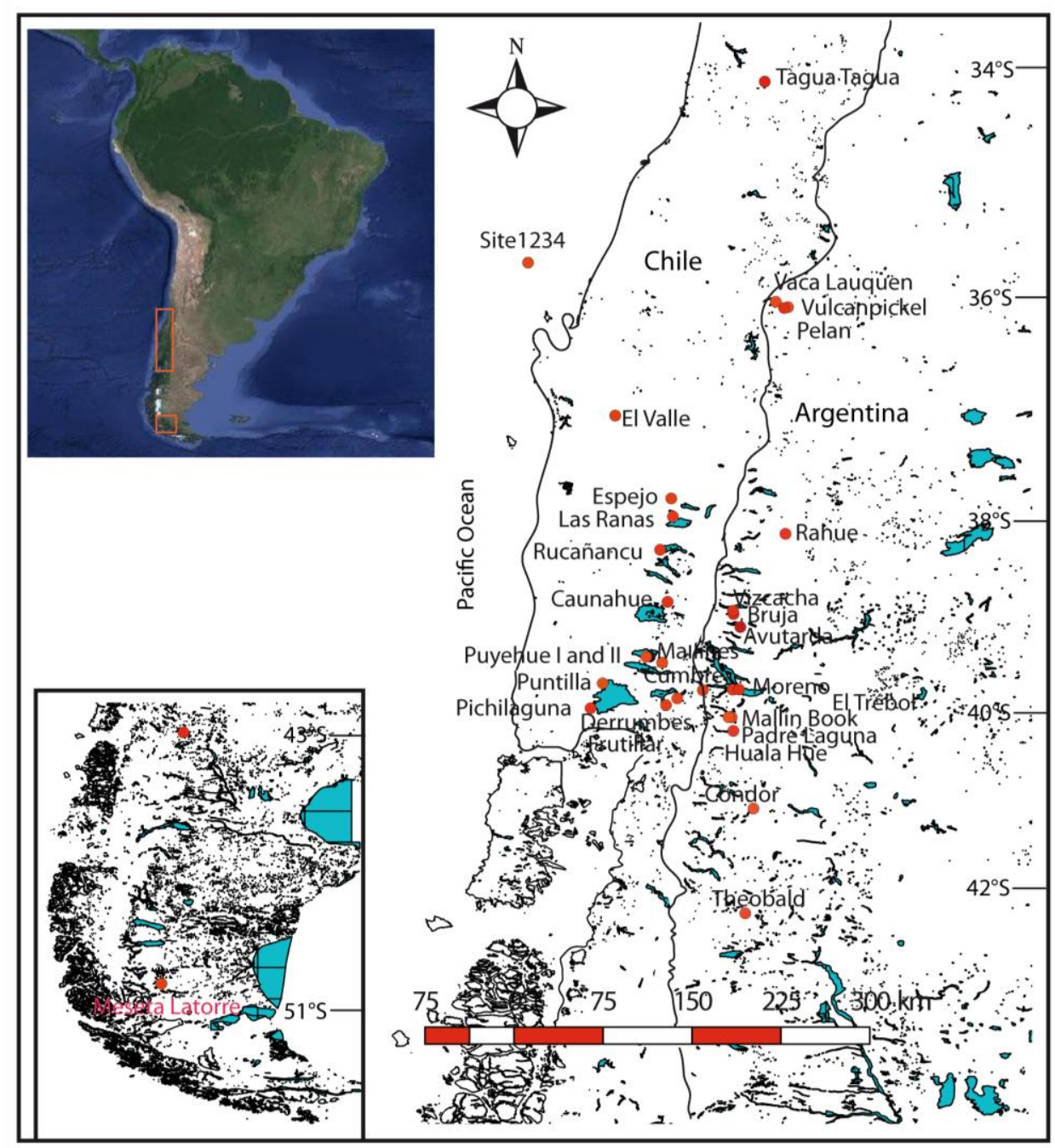

Figure 29. Map of the study area. At the right, the list of sites is displayed latitudinally $\left(34^{\circ}\right.$ to $\left.51^{\circ} \mathrm{S}\right)$. 


\subsubsection{Vegetation}

The vegetation in the study area is strongly related to precipitation, while natural disturbances and altitudinal and latitudinal fluctuations in temperature are considered as a secondary driver (Veblen et al., 1981). In Chile, the northernmost limit of the study area is characterized by sclerophyll vegetation (Tagua Tagua site, $34^{\circ} 30^{\prime} \mathrm{S} ; 7^{\circ} 10^{\prime} \mathrm{W}$ ). Here, Heusser (1983) describes hilltops $>500 \mathrm{~m}$ with the presence of Nothofagus obliqua and Nothofagus glauca. At the same latitude but on the Andean slopes, the evergreen Nothofagus dombeyi occurs together with N. obliqua, N. glauca, and N. alpina in sites up to $1500 \mathrm{~m}$. Markgraf et al. (2009) describe the vegetation around Lagunas de Epulauquen, which is the northernmost Argentinean limit of the deciduous Nothofagus obliqua. The area is dominated by high-elevation bunchgrass belonging to the genus Festuca and shrub elements from the families Asteraceae and Rhamnaceae. The genera Berberis, Eryngium, and Ephedra occur as well in their shrub forms. At higher altitudes Nothofagus antarctica and Nothofagus pumilio dominate. The conifer Austrocedrus chilensis is present at low elevations and dominates dry areas of this region (Donoso, 1982). 


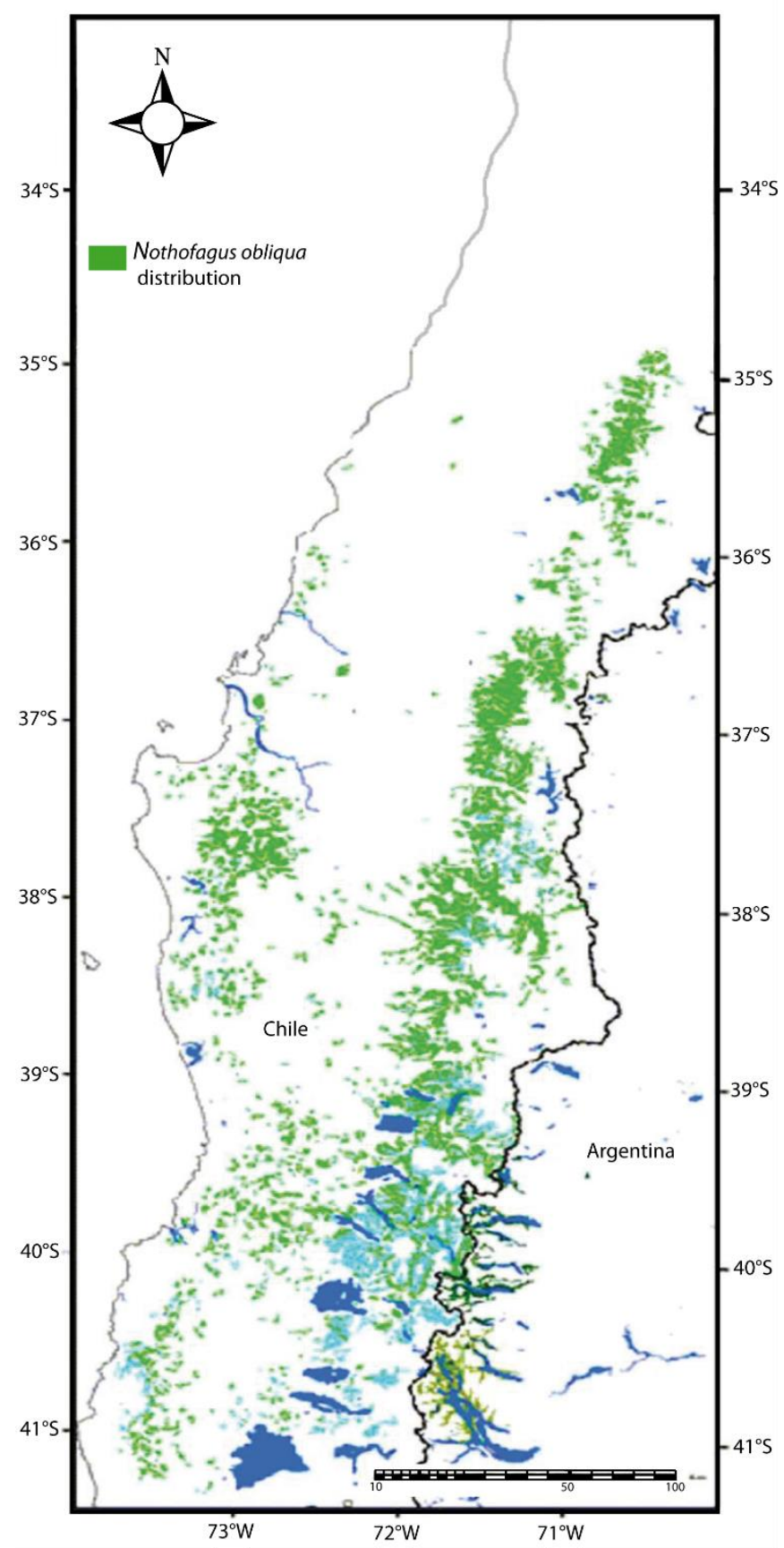

Figure 30. Distribution of Nothofagus obliqua in Chile and Argentina (green areas), adapted from Azpilicueta et al. (2016). Blue areas represent lakes. 


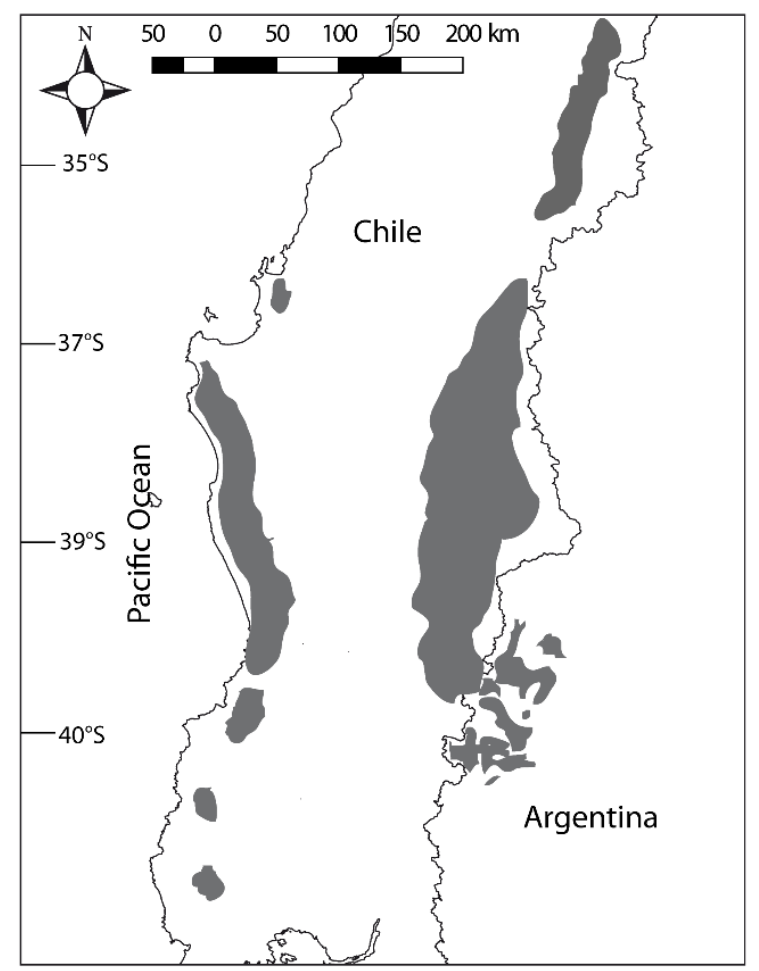

Figure 31. Schematic representation of the distribution of Nothofagus alpina in Chile and Argentina based on Donoso (2013). Notice that the grey area only represents the location of the population and not the size.

The Lowland Deciduous Forest occurs also in mountain regions of the Mediterranean transition zone in south-central Chile. The dominant tree species correspond to the Nothofagus genus. Deciduous broadleaved species Nothofagus alessandrii, N. alpina, N. glauca, and N. obliqua are dominant in the warmer lowlands whereas $N$. antactica and $N$. pumilio occur at cold-high elevations areas (Ramírez et al., 1997). Other species such as Lomatia hirsuta, Aristotelia chilensis, Misodendrum linearifolium and Schinus montana are present (Luebert and Pliscoff, 2017). Towards the south, in the Andean region between $34^{\circ} 40^{\prime} \mathrm{S} ; 70^{\circ} 40^{\prime} \mathrm{O}$ and $35^{\circ} 38^{\prime} \mathrm{S} ; 71^{\circ} 06^{\prime} \mathrm{O}$ and in the Central Valley between $36^{\circ} 44^{\prime} \mathrm{S} ; 72^{\circ} 03^{\prime} \mathrm{S}$ and $39^{\circ} 13^{\prime} \mathrm{S} ; 72^{\circ} 22^{\prime} \mathrm{O}(<1000 \mathrm{~m}$ a.s.l.) the vegetation is mainly dominated by Nothofagus obliqua, coupled with the presence of Cryptocarya alba and Peumus boldus. Among tree and shrub elements present in this region the following can be mentioned Aristotelia chilensis, Azara dentata, Chusquea quila, Lithraea caustica, Gevuina avellana, and Lapageria rosea (Luebert and Pliscoff, 2017). On the other hand, the forest in the Central Valley has been largely altered with the cultivation of exotic species such as Pinus and Eucalyptus or cleared entirely for the creation of open areas for crops cultivation and harvesting activities (Echeverría et al., 2006). 
At $\sim 38^{\circ} \mathrm{S}$ within the humid slopes of the Andes Cordillera appears the Valdivian evergreen forest dominated by Nothofagus dombeyi and conifers such as Austrocedrus chilensis, Podocarpus nubigenus, and Saxegothaea conspicua (Luebert and Pliscoff, 2017). The Argentinean Andean region between $39^{\circ} \mathrm{S} ; 71^{\circ} \mathrm{W}$ and $\sim 41^{\circ} \mathrm{S} ; 71^{\circ} \mathrm{W}$ is dominated by several Nothofagus species. For example, Nothofagus antarctica occurs in valleys and at the edges of lakes. Nothofagus pumilio reaches high elevations areas delimiting the treeline and some isolated individuals grow in regions further east close to the steppe. According to Donoso et al. (2004) and Ramirez et al. (1997) Nothofagus dombeyi grows in humid areas with moderate low temperatures along their entire distribution in the region. On the other hand, Conticello et al. (1996) indicates that among trees, the most important species are Nothofagus dombeyi, Nothofagus antarctica, Nothofagus obliqua, and Nothofagus alpina (in that order of importance). Chusquea culeou is the most abundant understory element, followed by Maytenus chubutensis, Berberis darwinii, Embothrium coccineum, Lomatia hirsuta, Ribes magellanicum, and Gaultheria poeppigii. In the herbaceous stratum, the most important elements are Osmorhiza chilensis, Holcus lanatus, Acaena ovalifolia, Alstroemeria aurea, and Blechnum sp.

In the study area, Nothofagus obliqua and Nothofagus alpina occurs together with some important conifers in the region. In Chile at $\sim 34^{\circ} 45^{\prime} \mathrm{S}$, Nothofagus obliqua occurs with Austrocedrus chilensis in humid sites as well as in south- and east-facing slopes (Veblen et al., 1995). Towards the south $A$. chilensis can form mixed forest with Nothofagus species in less extreme environments, especially with Nothofagus dombeyi in humid areas. Dezzotti and Sancholuz (1991) also report that this conifer co-occurs with Nothofagus alpina in areas with high precipitation (1600 and $2000 \mathrm{~mm}$ ) in Argentina between $40^{\circ} 10^{\prime}$ and $41^{\circ} 45^{\prime} \mathrm{S}$. Occasionally, in the Coastal Cordillera of Chile (Nahuelbuta; $37^{\circ} 43^{\prime} \mathrm{S}$ ) Nothofagus obliqua occurs with Araucaria araucana and Nothofagus antarctica on drier east-facing slopes at low elevations (Donoso, 2013; Veblen et al., 1995). 


\subsection{Material and Methods}

Pollen counts from sites in the study region with the presence of Nothofagus obliqua and Nothofagus alpina were obtained from two databases: The Data Publisher for Earth and Environmental Science PANGAEA (https://www.pangaea.de/) and NEOTOMA Palaeoecology Database and Community (https://www.neotomadb.org/). Additionally, journals, abstracts, reports, thesis, and book congresses related to Argentinean and Chilean palynological investigations were reviewed.

Since most of the pollen data presented on those publications were not available in open data repositories, the pollen diagrams were scanned and digitized to obtaining the percentage of Nothofagus obliqua-type using the free software WebPlotDigitizer (available at https://automeris.io/WebPlotDigitizer/). The records were classified into LGM (sensu Hulton et al., 2002), Deglacial period (sensu McCulloch et al., 2000), Early Holocene, Mid-Holocene, Late Holocene, and present time (last 200 years). A mean percentage was calculated per site per period. Maps were created using QGIS software. 
Table 11. List of the records available with the presence of Nothofagus obliqua pollen type.

\begin{tabular}{|c|c|c|c|c|}
\hline Site name & Author(s) & Age & Coordinates & Elevation ( $m$ a.s.I.) \\
\hline Tagua Tagua & Heusser, 1983 & $>45000{ }^{14} \mathrm{C}$ yr BP & $34^{\circ} 30^{\prime} \mathrm{S} ; 71^{\circ} 10^{\prime} \mathrm{W}$ & 200 \\
\hline Mallín Vaca Lauquen & Markgraf et al., 2009 & 16465 cal. yr BP & $35^{\circ} 51^{\prime} \mathrm{S} ; 71^{\circ} 02^{\prime} \mathrm{W}$ & 1567 \\
\hline Veranada Pelan & Schäbitz, 1989 & 10800 cal. yr BP & $36^{\circ} 88^{\prime} 33^{\prime \prime S} ; 70^{\circ} 38^{\prime \prime} 33^{\prime \prime W}$ & 1540 \\
\hline Site 1234 & Heusser et al., 2006 & 140000 years & $36^{\circ} 13^{\prime} \mathrm{S} ; 73^{\circ} 40^{\prime} \mathrm{W}$ & marine sediment core \\
\hline El Valle & Abarzúa et al., 2014 & $\sim 26000$ cal. yr BP & $38^{\circ} 05^{\prime} \mathrm{S} ; 72^{\circ} 47^{\prime} \mathrm{W}$ & 70 \\
\hline Lago Espejo & Abarzúa et al., 2013 & $10247^{14} \mathrm{C}$ yr BP & $39^{\circ} \mathrm{S} ; 72^{\circ} 10^{\prime} \mathrm{W}$ & 320 \\
\hline Laguna Las Ranas & Abarzúa, 2013 & $\sim 19000$ cal. yr BP & $39^{\circ} 11^{\prime} \mathrm{S} ; 72^{\circ} 05^{\circ} \mathrm{W}$ & 400 \\
\hline Bajada de Rahue & Markgraf et al., 1986 & 31000 cal. yr BP? & $39^{\circ} 22^{\prime} \mathrm{S} ; 70^{\circ} 56^{\prime} \mathrm{W}$ & 1000 \\
\hline Rucañancu & Heusser, 1984 & $10200 \pm 130$ & $39^{\circ} 33^{\prime} \mathrm{S} ; 72^{\circ} 18^{\prime} \mathrm{W}$ & 290 \\
\hline Vizcacha & Alvarez-Barra Valentina & 11700 cal. yr BP & $40^{\circ} 12^{\prime} \mathrm{S} ; 71^{\circ} 30^{\prime} \mathrm{W}$ & 1095 \\
\hline Bruja & Alvarez-Barra Valentina & 3600 cal. yr BP & $40^{\circ} 14^{\prime} \mathrm{S} ; 71^{\circ} 30^{\prime} \mathrm{W}$ & 1060 \\
\hline Caunahue & Markgraf 1991 & $13980 \pm 200$ & $40^{\circ} \mathrm{S} ; 72^{\circ} \mathrm{W}$ & 140 \\
\hline Puyehue I & deBatist et al., 2007 & 17400 cal. yr BP & $40^{\circ} 41^{\prime} \mathrm{S} ; 72^{\circ} 22^{\prime} \mathrm{W}$ & 187 \\
\hline Puyehue II & Vargas-Ramirez et al., 2008 & 15250-16750 cal. yr BP & $40^{\circ} 40^{\prime} \mathrm{S} ; 72^{\circ} 28^{\prime} \mathrm{W}$ & 185 \\
\hline Los Mallines & Vargas-Ramirez et al., 2008 & $3450-4100$ cal. yr BP & $40^{\circ} 46^{\prime} \mathrm{S} ; 72^{\circ} 17^{\prime} \mathrm{W}$ & 730 \\
\hline Canal de la Puntilla & Moreno, 1997 & 20200 cal. yr BP & $40^{\circ} 57^{\prime} 09^{\prime \prime} \mathrm{W} ; 72^{\circ} 54^{\prime} 18^{\prime \prime} \mathrm{W}$ & 120 \\
\hline Padre Laguna & Iglesias et al., 2012 & 4963 cal. yr BP & $41^{\circ} 21^{\prime} 34^{\prime \prime S} ; 71^{\circ} 30^{\prime} 32^{\prime \prime W}$ & 1280 \\
\hline Huala Hue & Iglesias et al., 2012 & $13180 \mathrm{cal} . \mathrm{yr} \mathrm{BP}$ & $41^{\circ} 30^{\prime} 24^{\prime \prime S} ; 71^{\circ} 30^{\prime} 32^{\prime \prime} \mathrm{W}$ & 849 \\
\hline Lago Moreno & Valencio et al., 1985 & 14500 cal. yr BP & $41^{\circ} 05^{\prime} \mathrm{S} ; 71^{\circ} 51^{\prime} \mathrm{W}$ & 780 \\
\hline Laguna el Trébol & $\begin{array}{l}\text { Whitlock et al. 2006/Bianchi et al., } \\
1999\end{array}$ & $15041-15313$ cal. yr BP & $41^{\circ} \mathrm{S} ; 71^{\circ} \mathrm{W}$ & 758 \\
\hline La Cumbre & Villagrán, 1980 & $6335 \pm 70$ & $41^{\circ} 04^{\prime} \mathrm{S} ; 71^{\circ} 50^{\prime} \mathrm{W}$ & 975 \\
\hline Derrumbes & Villagrán, 1980 & $3110 \pm 105$ & $41^{\circ} 09^{\prime} \mathrm{S} ; 72^{\circ} 06^{\prime} \mathrm{W}$ & 820 \\
\hline El Frutillar & Villagrán, 1980 & $2390 \pm 70$ & $41^{\circ} 08^{\prime} \mathrm{S} ; 73^{\circ} 00^{\prime} \mathrm{W}$ & 920 \\
\hline Laguna Condor & Iglesias et al., 2011 & 17845 cal. yr BP & $42^{\circ} 20^{\prime} 47.22^{\prime \prime S} ; 71^{\circ} 17^{\prime} 07.62^{\prime \prime W}$ & 818 \\
\hline Lago Theobald & $\begin{array}{l}\text { Iglesias, 2013; Iglesias and } \\
\text { Whitlock, 2014; Iglesias et al., } \\
2014\end{array}$ & 12200 cal. yr BP & $43^{\circ} 48^{\prime} \mathrm{S} ; 71^{\circ} 58^{\prime} \mathrm{W}$ & 678 \\
\hline Meseta Latorre & Schäbitz, 1989 & 7100 cal. yr BP & $51^{\circ} 51^{\prime} 66^{\prime \prime} \mathrm{S} ; 72^{\circ} 05^{\prime} \mathrm{W}$ & 973 \\
\hline
\end{tabular}




\subsection{Results}

A total of 30 records with the presence of Nothofagus obliqua-type were found (Table 11, Figure 29) and they encompass the modern geographical distribution of Nothofagus obliqua and Nothofagus alpina in South America ( $34^{\circ}$ to $\left.41^{\circ} \mathrm{S}\right)$. However, sites such as Padre Laguna, Huala Hue, Lago Moreno, Mallín Book, Lago Theobald, and Meseta Latorre $\left(42^{\circ}\right.$ to $\left.51^{\circ} \mathrm{S}\right)$ have values $<1 \%$ in $N$. obliqua-type and can be representing long-distance transport of the pollen type from populations located around $40^{\circ} \mathrm{S}$ through westerly winds. The same interpretation can be applied to sites Veranada Vulkanpickel and Veranada Pelan $\left(36^{\circ} \mathrm{S}, 70^{\circ} \mathrm{W}\right)$ and Bajada de Rahue $\left(39^{\circ} \mathrm{S}\right)$ which likely might receive pollen from populations located nearby the Andes at the same latitude.

The pollen diagrams from Tagua Tagua, Site 1234, and Bajada de Rahue recorded Nothofagus obliqua-type pollen between 23000 and 30000 cal. yr BP with 6.6\%, 9.2\%, and $0.6 \%$ respectively (Figure 30). Nevertheless, Tagua Tagua and Site 1234 are the oldest records (> 45000 and 140000 cal. yr BP respectively) documenting the presence of $N$. obliqua pollen type since their beginnings with $7 \%$ in Tagua Tagua and $8.9 \%$ in Site 1234. During the Last Glacial Maximum (LGM) the percentage of $N$. obliqua-type in Tagua Tagua declined slightly while in Site 1234 was stable. The site El Valle, Pichilaguna, Canal de la Puntilla, and Laguna El Trébol documented for this period percentages $>1 \%$, except for EI Valle, which during the LGM recorded $2.8 \%$ of $N$. obliqua-type. The Deglacial period (see Figure 32) was characterized by high percentages of Nothofagus obliqua-type in Puyehue I and Puyehue II $\left(40^{\circ} \mathrm{S}, 72^{\circ} \mathrm{W} ; 10 \%\right.$ and $12 \%$ respectively); in Site 1234 (9.5\%) and only 2\% in Lago Moreno and Tagua Tagua. In Argentina during the postglacial, the sites Mallín Vaca Lauquen, Huala Hue, Laguna El Trébol, and Mallín Book present $<1 \%$ of Nothofagus obliqua pollen type. 

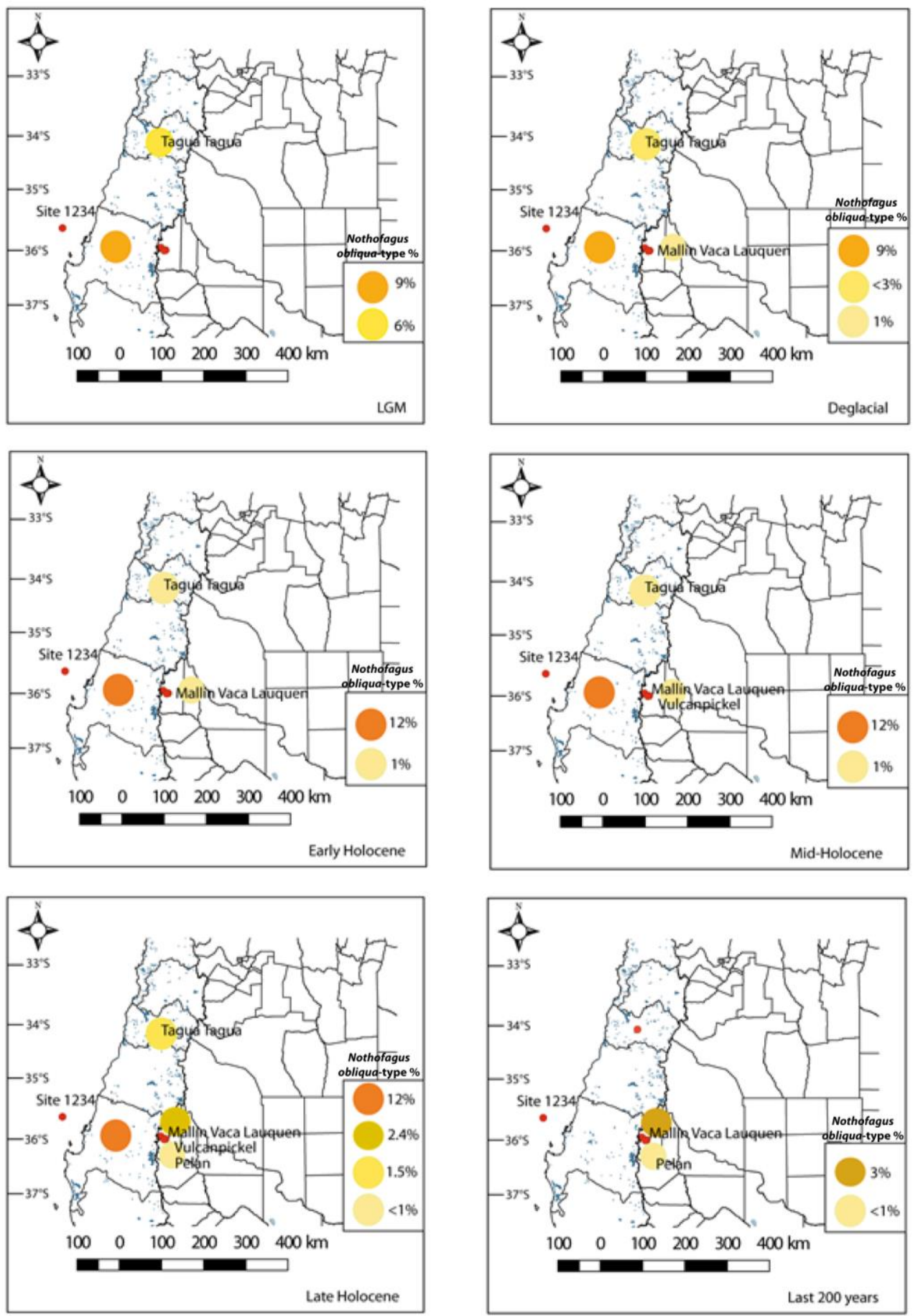

Figure 32. Maps with the changes in the percentage of $N$. obliqua-type since the LGM to the last 200 years in the sites located at the north of the study area. Percentages are represented as coloured circles. See the label at the right-bottom for the period. 
In the Early Holocene, sites located at the northernmost limit of Nothofagus in South America present values $<1 \%$ for $N$. obliqua. These low percentages are also documented in sites in the south $\left(40^{\circ}-43^{\circ} \mathrm{S}\right)$ such as Vizcacha, Caunahue, Pichilaguna, Canal de la Puntilla, Huala Hue, Lago Moreno, Laguna El Trébol, and Lago Theobald. On the other hand, a rise in the percentage of N. obliqua-type occurred after 12000 cal. yr BP in sites located at mid-latitudes such as Site 1234, El Valle, Laguna Las Ranas, and Puyehue I and II. Based on the records, a major population of Nothofagus obliqua and/or Nothofagus alpina might have been located in the Coastal Cordillera and Central Valley between $36^{\circ}$ and $38^{\circ} \mathrm{S}$ (Site 1234 and El Valle respectively); in the Central Valley at $39^{\circ} \mathrm{S} ; 72^{\circ} \mathrm{W}$ (Rucañancu) as well as in the Central Valley at $40^{\circ} \mathrm{S}, 72^{\circ} \mathrm{W}$ (Puyehue I and II). Among all the records with the presence of Nothofagus obliqua during the Early Holocene, the highest percentage is registered in La Cumbre (16.5\%) at $41^{\circ} \mathrm{S}$, site located at the Andes of Chile.

A second pulse of increasing in the percentage of Nothofagus obliqua-type occurred during the MidHolocene (see Figure 33), as it is observed in El Valle, Laguna Las Ranas ( $38^{\circ}-39^{\circ} \mathrm{S}$, Central Valley) and Puyehue I and II $\left(40^{\circ} \mathrm{S}\right)$. Interestingly is the fact that for this period the site Rucañancu show a substantial increase in the percentage of $N$. obliqua-type from $11 \%$ during the Early Holocene to $39 \%$ in the Mid-Holocene. On the other hand, the site Derrumbes $\left(41^{\circ}, 72^{\circ} \mathrm{W}\right)$ documents $64 \%$ of $N$. obliqua-type while the site La Cumbre, located $20 \mathrm{~km}$ at the north-east show a decrease in the percentage during this period.

During the Late Holocene, some sites show a decrease in the percentage of $N$. obliqua pollen type, like Rucañancu, Puyehue I and II, La Cumbre, and Derrumbes. Other sites documented a slight increase in the percentage such as Tagua Tagua, Mallín Vaca Lauquen, El Valle, Laguna Las Ranas, and Laguna Condor. On the other hand, sites like Lago Espejo (Chile, $39^{\circ} \mathrm{S}, 72^{\circ} \mathrm{W}$ ) and Vizcacha (Argentina, $40^{\circ} \mathrm{S}, 71^{\circ} \mathrm{W}$ ) show an important increase in the percentage of $\mathrm{N}$. obliqua-type during the Late Holocene. Finally, based on the percentage of the topmost sample of each record, during the last 200 years highest percentages on the pollen type are registered in sites located within areas where the major population of Nothofagus obliqua and Nothofagus alpina in South America nowadays occur. 

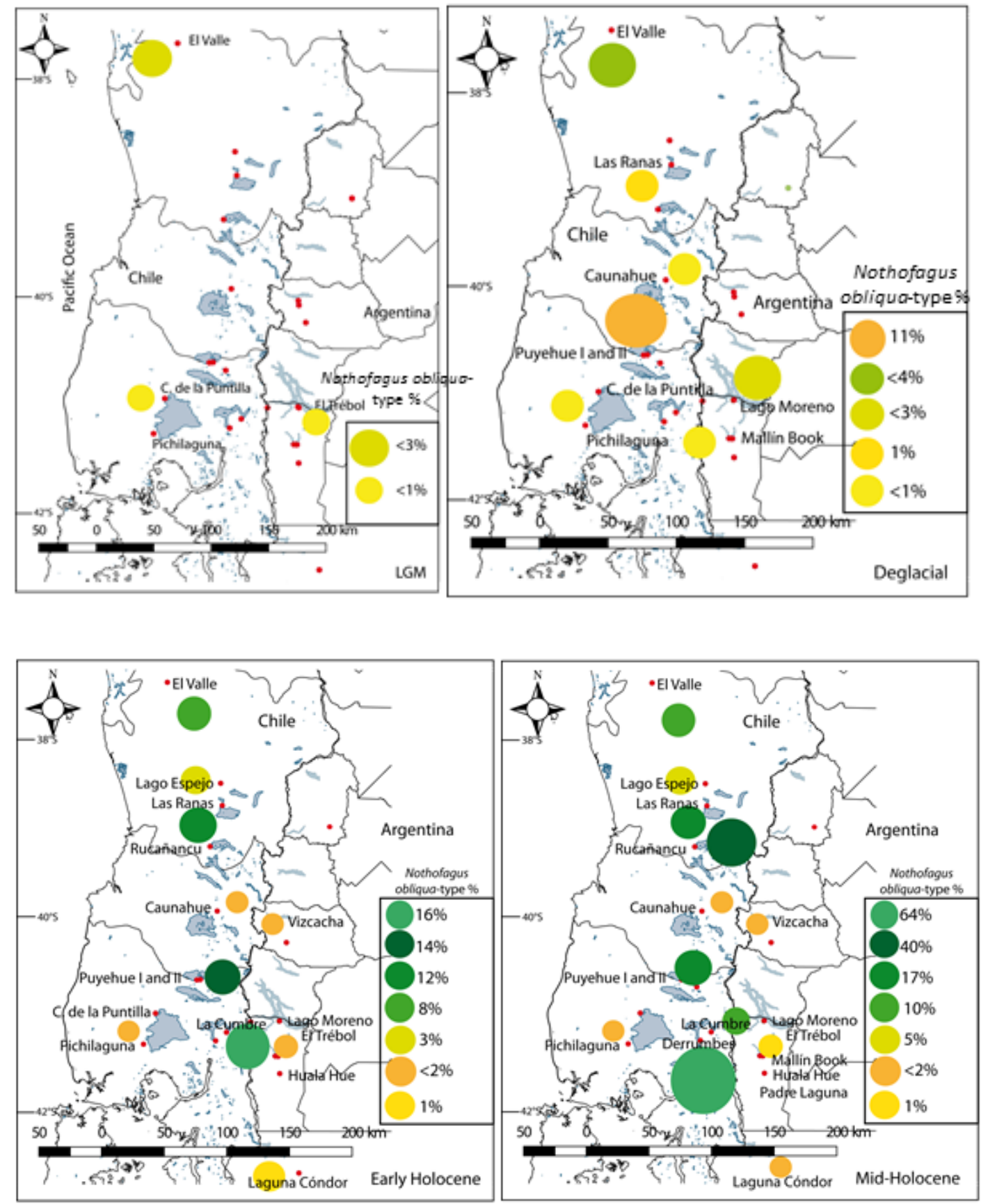

Figure 33. Maps with the changes in the percentage of $N$. obliqua-type since the LGM to the last 200 years, indicated as coloured circles on the map, of the sites located in the south of the study area. See the label at the right-bottom for the period. The sites named on each map correspond to those that report the presence of the pollen type in the specified time period. Continue next page. 


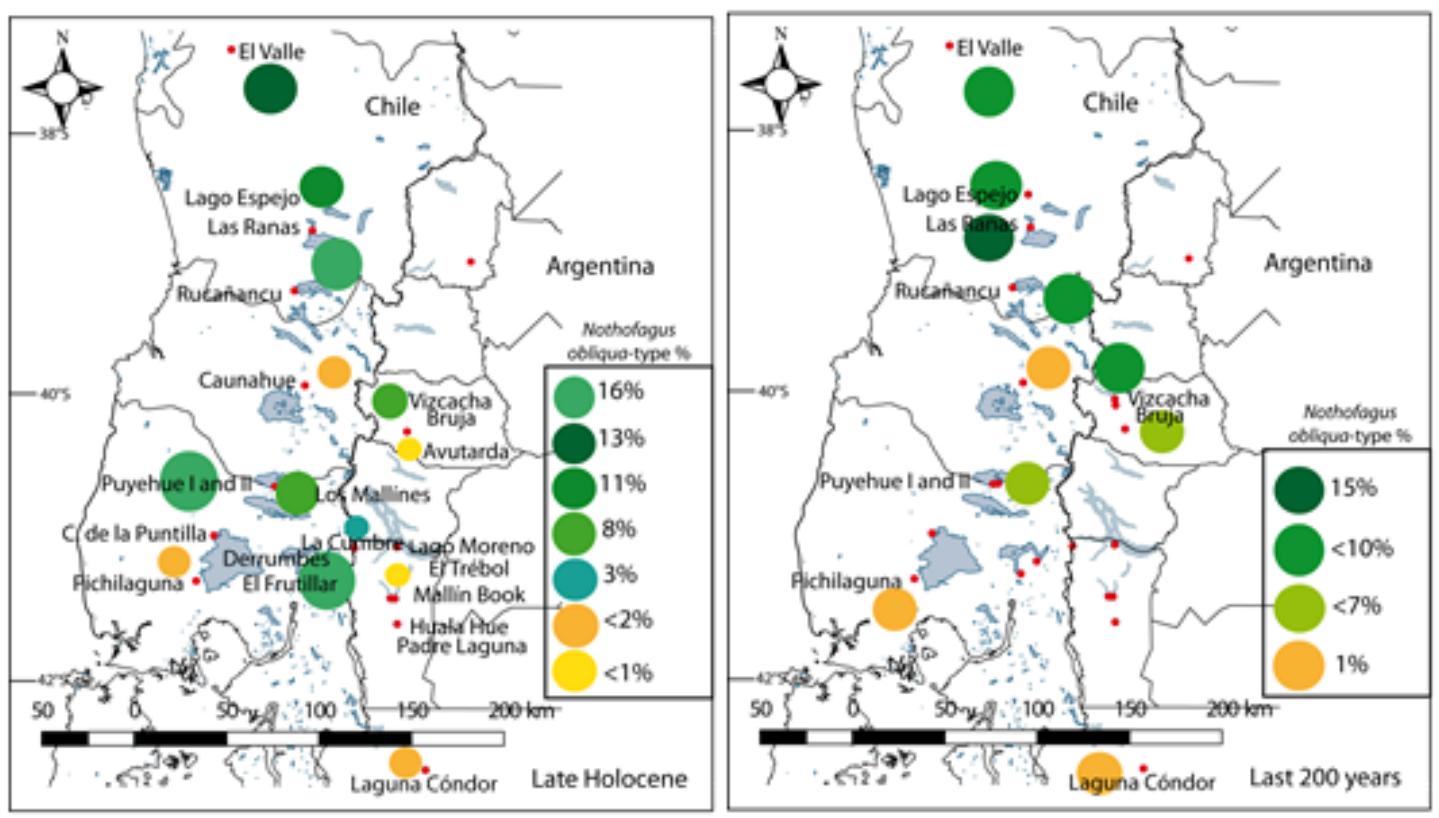

Figure 33. Continuation.

\subsection{Discussion}

Long-term changes in the distribution of Nothofagus obliqua and Nothofagus alpina are inferred based on 30 different sites located in Chile and Argentina. The oldest records correspond to Tagua Tagua, Site 1234, and Bajada de Rahue suggesting the presence of likely Nothofagus obliqua and Nothofagus glauca in the region of Tagua Tagua $\left(34^{\circ} \mathrm{S}\right)$, and Nothofagus obliqua and Nothofagus alpina in the Site $1234\left(36^{\circ} \mathrm{S}\right)$. The percentage during the LGM of N. obliqua-type is the Site 1234 and Tagua Tagua, resemble those reported for the last hundred years in sites located between $38^{\circ}$ and $40^{\circ} \mathrm{S}$ such as El Valle and Lago Espejo in the Central Valley of Chile, in Lake Bruja and Avutarda in western Patagonia Argentina, and in Puyehue I and II in the south limit of the central Valley of Chile. In the literature, it has been proposed that ice free areas during the LGM such as the Coastal Cordillera and northern regions of the Central Valley were refugia for several species (Villagrán, 1991; Villagrán et al., 1998; Villagrán, 2000). As Tagua Tagua basin is located at the eastern edge of the Coastal Cordillera ( $34^{\circ} 30^{\prime} \mathrm{S}, 71^{\circ} 10^{\prime} \mathrm{W} ; 200 \mathrm{~m}$ a.s.l.) it is suggested that this zone was possibly a refugium for populations of Nothofagus obliqua and Nothofagus glauca. Here, Heusser (1983) suggested that the climatic conditions that supported this vegetation were likely warmer and with more precipitation than today. The Site 1234 captures the pollen signal from both Coastal mountains and Andean foothills, and similar to Tagua Tagua it might reflect the presence as well of Nothofagus obliqua-type forest located in ice-free areas during the LGM, and LGM termination. 
Azpilicueta et al. (2009) investigated the chloroplast DNA of Nothofagus obliqua populations covering most of the modern distribution range in Chile and Argentina. They conclude that ancestral haplotypes only present in populations located in the Coastal mountains support the palynological hypothesis of glacial refugia during the LGM in this region.

During the Deglacial period, the percentage of $N$. obliqua in Tagua Tagua declined, which is parallel to an increase in the percentage of Nothofagus dombeyi and Podocarpus (see Heusser, 1983). The presence of both taxa suggests an increase in precipitation and likely lower summer temperatures than today (Heusser, 1983). This shift from warm and wet to cool and humid might explain the decline of the population in the area. Unlike Tagua Tagua, Site 1234 did not show a decline of the pollen type during the Deglacial period, suggesting latitudinal asynchronies that Heusser et al. (2006) attribute to variations in atmospheric circulation and snowline depression.

Temperate and semi-humid climatic conditions at $40^{\circ} \mathrm{S}$ are inferred by the presence of $\mathrm{N}$. obliquatype in the site Puyehue I and Puyehue II, both located at the Andes foothills during the Deglacial period. As the percentage of N. obliqua-type is around $11 \%$ at both sites, the regional presence of an abundant Lowland Deciduous Forest at this latitude is suggested. Based on the map of the extension of the ice-sheet during the LGM developed by Porter (1981) for the region between $39^{\circ}$ and $41^{\circ} \mathrm{S}$ the area of the Lake Puyehue was covered by ice during the LGM. On the other hand, a sediment core was taken from this lake, whose bottom was dated in 17900 cal. yr BP determining that the lake was not in contact with glacier ice during this period. Given these constraints the Lowland Deciduous Forest must have rapidly colonized these areas recently released of ice. Toward the north, the site El Valle $\left(38^{\circ} \mathrm{S}\right)$ documented $3 \%$ of $N$. obliqua-type during the Deglacial period, percentages similar to the modern values documented in Mallin Vaca Lauquen in Argentina $\left(35^{\circ} \mathrm{S}\right)$. This site shows a moderate increase in the percentage of this pollen type in comparison with the LGM period, suggesting a small abundance of the Lowland Deciduous Forest associated with warmer and less wet climate conditions (Abarzúa et al., 2014). Sites such as Caunahue, Pichilaguna, Canal de la Puntilla, Huala Hue, Laguna El Trébool, and Mallín Book recorded percentages $<1 \%$ during the Deglacial period and it is assumed that they are capturing extra local pollen of N. obliqua-type. Nevertheless, the $2 \%$ documented in Lago Moreno $\left(41^{\circ} \mathrm{S}\right)$ could reflect a small population of Nothofagus obliqua-type forest at southern latitudes.

Most of the sites mentioned show a rise in the percentage of $N$. obliqua-type during the Early Holocene such as the Site 1234 (from 9.5\% to 12.7\%), El Valle (from 3.6\% to 8\%), Laguna Las Ranas (from $1 \%$ to $12 \%$ ), and Puyehue I and II (from $11 \%$ to $14 \%$ ). In the literature, in mid-latitudes ( $38^{\circ}-$ 
$39^{\circ} \mathrm{S}$ ), the Early Holocene has been characterized as a warm and dry period. This interpretation is based on the rise in thermophilus taxa in the region, especially along the western slopes of the Andes with taxa such as Eucryphia/Cladcluvia, Axtoxicon punctatum, Weinmannia trichosperma, and Nothofagus obliqua-type. Additionally, increased fire activity during the Early Holocene has been detected for this period. On the eastern Andes, the Early Holocene was characterized by increased fire activity within the forest-steppe ecotone associated with arid summers and moist winters (Iglesias et al., 2011; Whitlock et a., 2006). Most of the sites with a sharp increase in $N$. obliqua-type are located in the Central Valley and they suggest a rapid development and expansion from small populations of the Lowland Deciduous Forest given the warming pulse inferred for the Early Holocene. The opposite pattern is observed in sites further north such as Tagua Tagua which shows a decline in the pollen type, associated with a replacement of Lowland Deciduous Forest by parkland with an abundance of Chenopodiaceae, Poaceae, and Asteraceae (Heusser et al., 1983).

Rucañancu $\left(39^{\circ} \mathrm{S}\right)$ and La Cumbre $\left(41^{\circ} \mathrm{S}\right)$ records start during this period and document $11 \%$ and $16 \%$ of $N$. obliqua-type respectively. The site Rucañancu has been postulated as possible centre of refugia for N. obliqua and N. alpina in the Central Valley (Villagrán, 1991) from where both species expanded northward and southward. The site La Cumbre present values of $N$. obliqua-type similar to those reported for modern populations located at $39^{\circ} \mathrm{S}$ near the west Andes foothills. Villagrán (1991) suggests that $N$. obliqua and $N$. alpina expanded toward the south along the Andes from northern populations, reaching a more southernmost limit than today between 9500 and 3000 cal. yr BP due to the warming pulse characteristic of the Early Holocene. The site La Cumbre is located at the border with Argentina, at $\sim 50 \mathrm{~km}$ south of the modern southern limit of N. alpina in Argentina (Sabatier et al., 2011). The record from Vizcacha indicate percentages of $<1 \%$ of $N$. obliqua for the Early Holocene and based on the hypothesis of the south- and northward expansion of $N$. obliquatype forest along the Andes, this scarce percentage might represent long-distance transport either from populations located at the north in the Central Valley such as Rucañancu, or from southern Andean populations such as Puyehue I and II. 


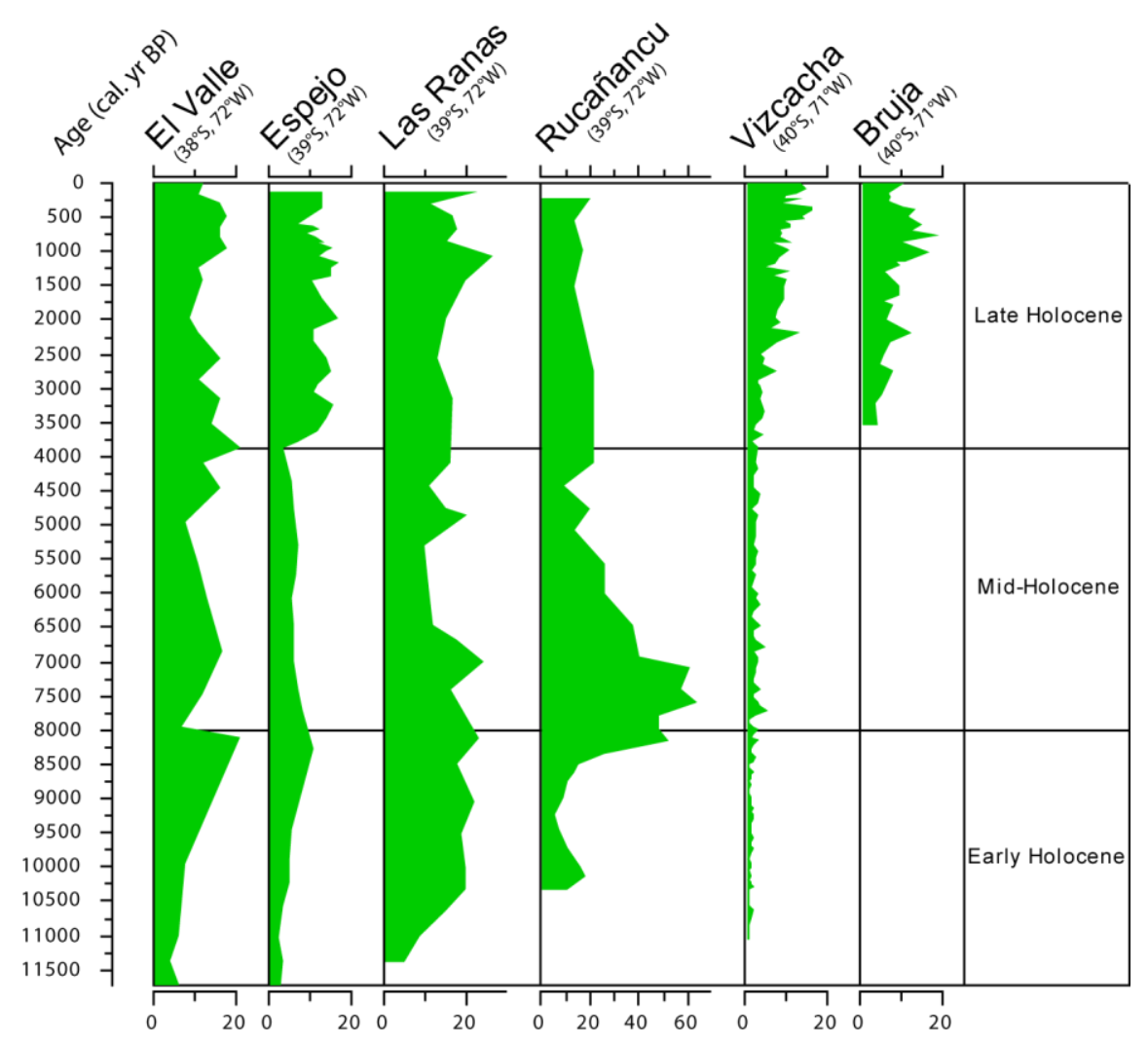

Figure 34. Summary diagram with the main records from mid-latitudes southern South America discussed in this work.

During the Mid-Holocene, the Site 1234 indicates stable percentages of $N$. obliqua-type in comparison with the prior period suggesting the establishment of the Lowland Deciduous Forest likely at the Andes foothills. The records from EI Valle to Lago Espejo document a slight increase in the percentage of the pollen type, suggesting that the climatic conditions prevailed optimal for the growth and establishment of $N$. obliqua and $N$. alpina. A substantial increase in the percentage of Nothofagus obliqua-type forest occurs in areas within the Central Valley and the Andes foothills, as it is documented in Lago Espejo, Las Ranas, and Rucañancu. Nevertheless, the maximum percentage documented for this period was found in Derrumbes with 64\%. Villagrán (1980) suggests an altitudinal displacement of Nothofagus dombeyi-type (humid forest indicator) due to the warmer and drier conditions, whereas N. obliqua-type advanced along the Central Valley and Andes foothills. The author also emphasises the fact that this high percentage might indicate the presence of a pure Nothofagus obliqua-type forest. Hitherto, there is no modern analogue to compare with that represent this type of forest. The decline in the percentage of $N$. obliqua-type in the site La Cumbre, located at $\sim 20 \mathrm{~km}$ north-east might indicate a westward displacement of the populations during this period, which in part could explain the increased percentage of $N$. obliqua-type in Derrumbes. The increased percentage of the pollen type in Lago Espejo, Las Ranas, and Rucañancu support the 
hypothesis of a southward displacement of the Lowland Deciduous Forest along the Central Valley and the Andes.

Despite that sites such as Rucañancu, Las Ranas, and Lago Espejo show a rise in the percentage of N. obliqua-type during the Early and Mid-Holocene, the site Caunahue (Heusser, $1981 ; 40^{\circ} \mathrm{S} ; 72^{\circ} \mathrm{W}$; $140 \mathrm{~m}$ a.s.l.) indicates values $<1.8 \%$. Rucañancu, located at $60 \mathrm{~km}$ north of Caunahue documented $39 \%$ of N. obliqua-type and the site Puyehue I and II, located $60 \mathrm{~km}$ south shows $17 \%$ during the Mid-Holocene. The site Caunahue corresponds to a south-east exposed riverbank profile which is surrounded by a several mountains chain associated with the Andes. This might explain the low percentage documented in this record.

Disturbance has been proposed as a cause of interruption of migratory routes. For example, Azpilicueta et al. (2009) suggest that dissimilarities in haplotypes among southern and northern populations of Nothofagus obliqua in Argentina might be due to an explosion of the Lanín volcano during postglacial re-colonization of the species. This phenomenon might have occurred during the Late Holocene northward advance of the Nothofagus obliqua-type forest proposed by Villagrán (1991). The site Derrumbes shows a decline in the percentage of the pollen type while at the site Los Mallínes the pollen increases up to 3\%. However, in Caunahue the pollen signal did not increase. Between Caunahue and the sites Los Mallínes, Puyehue I and II, and Derrumbes is the PuyehueCordón Caulle Volcanic Complex, one of the most active volcanoes in south-central Chile, with more than 20 eruptive periods detected during the last 5000 years (Global Volcanism Program, Smithsonian Institution, 2019). The constant volcanic activity might have caused an impact on the Lowland Deciduous Forest during its advance in the Late Holocene.

The Late Holocene has been proposed as a period where the current climatic conditions start to establish in the region (Lamy et al., 2010; Markgraf et al., 2009), as well as the increase ENSO activity, which is responsible for decadal anomalies in rainfall (Montecinos and Aceituno, 2003). Sites at $40^{\circ} \mathrm{S}$ in the eastern Andes such as Vizcacha and Bruja show a rise in the abundance of the pollen type. Towards the north, the site Mallín Vaca Lauquen also indicate increased percentages of $N$. obliquatype. Markgraf et al. (2009) suggest that the abundance of the pollen type responds to the establishment of the winter rain/summer drought climatic conditions in the area. The population of Nothofagus obliqua around Lagunas de Epulaquen (the located of Mallín Vaca Lauquen) has been extensively studied in terms of their genetic characterization (Azpilicueta et al., 2016; Azpilicueta et al., 2014). Their analysis supports the hypothesis of a common origin for $N$. obliqua population west and east of the Andes at this latitude $\left(36^{\circ} 49^{\prime} \mathrm{S}, 71^{\circ} 04^{\prime} \mathrm{W}\right)$, suggesting the convergence of migratory 
routes in this geographical area (Azpilicueta et al., 2016). This might explain the gradual increase of the populations located at Lagunas de Epulauquen since the Deglacial period, by introgression from western populations during postglacial recolonization (Azpilicueta et al., 2009; 2014; Markgraf, 1987).

The last 200 years reflect the modern distribution of Nothofagus obliqua and Nothofagus alpina in Chile and Argentina (see Figures 30 and 31). This is the Coastal Cordillera of Chile (El Valle and Site 1234), Lagunas de Epulauquen in Argentina (Mallín Vaca Lauquen), and the Andes of Chile and Argentina between $39^{\circ}$ and $41^{\circ} \mathrm{S}$. Nevertheless, although the palynological records available are located within the main populations of both deciduous beech species, areas towards the south in Chile (nearby Puyehue I and II and Pichilaguna) as well as regions in Argentina (north of Lake Vizcacha) hitherto has not been investigated to understand their past vegetation history to filling empty gaps regarding the possible presence of glacial refugia located in periglacial areas, especially in Argentina.

Both, Nothofagus alpina and obliqua has been intensively used for timber extraction for the last two centuries (Donoso, 1988; Weinberger and Ramirez, 1999) and in general, since the arrival of the Spanish conquers, the original forest especially in south Chile has declining due to deliberated burning to prevent indigenous people hiding during battles (Gardner et al., 2006), and to create suitable land for crop cultivation and animal husbandry. Since 1970 the introduction of exotic species such as Pinus and Eucalyptus has been also an important factor in the decline of native forest. However, restoration of both Nothofagus alpina and Nothofagus obliqua has captured the attention of silvicultural management in Argentina as well in Chile. Genetic characterization and site indexes have been published for conservation, protection, and restoration strategies.

\subsection{Conclusions}

Combining the information from available pollen diagrams with the presence of Nothofagus obliqua-type in South America, the following conclusion arise: 1) a clear expansion of the N. obliqua type immediately after the LGM, associated with warmer conditions and the presence of new icefree areas where any of both species could have colonized; 2) sites located in the Central Valley of Chile show variable, but continues percentages of the pollen type since the Mid-Holocene, especially those located at $38^{\circ} \mathrm{S} ; 3$ ) the presence of the pollen type in sites located within the Argentinean steppe (Veranada Pelan and Vulcanpickel) and in southern latitudes as Huala Hue, Laguna El Trébol, Mallín Book, Lago Theobald $\left(41^{\circ}\right.$ to $\left.43^{\circ} \mathrm{S}\right)$ and Meseta Latorre $\left(51^{\circ} \mathrm{S}\right)$ correspond to long-distance 
transport of the pollen by the westerly winds system and they might not represent a local presence of the trees and 4) the changes observed through time indicate a very dynamic vegetation history of the N. obliqua-type forest, reflecting the sensitive and fast response of these deciduous trees to the drastic changes in climatic conditions in the region. Hitherto, this work is one of the first to synthetize most of the palynological records available with the presence of Nothofagus obliqua-type in South America. Nevertheless, this work also provides evidence about the continued lack of vegetation reconstructions in mid-latitudes in Chile and Argentina, which might help to understand the dynamic of the Lowland Deciduous Forest before and after the LGM and therefore provide a better understanding of the possible behaviour of both Nothofagus obliqua and Nothofagus alpina under a future climatic warming scenario.

\section{Acknowledgements}

I would like to thank Dr. Thomas Giesecke for his valuable comments during the development of this chapter.

\section{References}

Abarzúa AM, Pichincura AG, Jarpa L, Martel-Cea A, Sterken M, Vega R, Pino M (2014) Environmental responses to climatic and cultural changes over the last 26000 years in Purén-Lumaco valley $\left(38^{\circ} \mathrm{S}\right)$ in Tom D. Dillehay (ed), The Teleoscopy Polity. New York, Springer DOI:10.1007/978-3-319-03128$6 \_6$

Abarzúa AM (2013) Glacial-Interglacial history of the northern margin of westerly winds in southcentral Chile $\left(35^{\circ}-39^{\circ} \mathrm{S}\right)$. Informe Final Etapa 2013.Programa FONDECYT. Comisión Nacional de Investigación Científica y Tecnológica.

Abarzúa AM, Kilian R, Maldonado A (2013) Cambios vegetacionales desde el Glacial al Holoceno en Laguna Espejo, centro-sur de Chile (395). Libro de resúmenes III Simposio Paleontología en Chile. Punta Arenas 11-13 Octubre 2012. pp 19-22.

Acosta MC, Premoli AC (2010) Evidence of chloroplast capture in South American Nothofagus (subgenus Nothofagus, Nothofagaceae). Molecular Phylogenetics and Evolution 54:235-242.

Amigo J, Rodríguez-Guitian A (2011) Bioclimatic and phytosociological diagnosis of the species of the Nothofagus genus (Nothofagaceae) in South America. International Journal of Geobotanical Research 1:1-20. 
Azpilicueta MM, El Mujtar VA, Gallo LA (2016) Searching for molecular insight on hybridization in Nothofagus spp. forests at Lagunas de Epulauquen, Argentina. Bosque 37(3):591-601.

Azpilicueta MM, Pastorino MJ, Puntieri J et al. (2014) Robles in Lagunas de Epulaquen, Argentina: previous and recent evidence of their distictive character. Revista Chilena de Historia Natural 84:24. Azpilicueta MM, Marchelli P, Gallo LA (2009) The effects of Quaternary glaciations in Patagonia as evidnced by chloroplast DNA phylogeography of Southern beech Nothofagus obliqua. Tree Genetics and Genomes 5:561-571.

Bianchi AR, Cravero SAC (2010) Atlas climático digital de la República Argentina. Ediciones INTA

Bianchi MM (1999) Registros polínicos de la transición Glacial-Post-glacial en el Parque Nacional Nahuel Huapi, noroeste de Patagonia, Argentina. Asociación Paleontológica Argentina. Publicación Especial 6. X Simposio Argentino de Paleobotánica y Palinología: 43-48. Buenos Aires, 30-08-1999

Campagnucci RH, Araneo DC (2007) Alcances de El Niño como predictor del caudal de los ríos andinos argentinos. Ingeniería Hidráulica en México 12(3):23-35.

Conticello L, Gandullo R, Bustamante A, Tartaglia C (1996) Fitosociología de los bosques caducifolios del norte del Departamento Lácar y sur de Huiluches de la provincia de Neuquén (Argentina). Bosque 17(2):27-43.

De Batist M, Fagel N, Loutre MF et al. (2007) A continuous Holocene record of ENSO variability in southern Chile (ENSO-CHILE). Belgian Science Policy, final report part II: global change, ecosystems and Biodiversity.

Dettmann E, Pocknall DT, Romero EJ, Zamaloa M del C (1990) Nothofagidites Erdtman ex Potonie 1960: a catalogue of species with notes on the paleogeographic distribution of Nothofagus BI (southern beech). New Zealand Geological Survey paleontological bulletin 60:1-79.

Dezzotti A, Sancholuz L (1991) Los bosques de Austrocedrus chilensis en Argentina: ubicación, estructura y crecimiento. Bosque 12(2):43-52.

Donoso C (2013) Las especies arbóreas de los bosques templados de Chile y Argentina. Autoecología. Marisa Cuneo Ediciones. Valdivia-Chile.

Donoso P, Donoso C, Sandoval V (1993) Proposición de zonas de crecimiento de renovales de roble (Nothofagus obliqua) y raulí (Nothofagus alpina) en su rango de distribución natural. Bosque 14(2): $37-55$. 
Donoso C, Morales J, Romero M (1990) Hibridación Natural entre roble (Nothofagus obliqua) (Mirb) Oerst. y Raulí (N. alpina) (Poepp. \& Endl.) Oerst, en bosques del sur de Chile. Revista Chilena de Historia Natural 63:49-60.

Donoso P (1988) Caracterización y proposiciones silviculturales para renovales de Roble (Nothofagus obliqua) y Raulí (Nothofagus alpina) en el área de protección "Radal 7 Tazas", VII Región. Bosque 9(2):103-114.

Donoso C (1982) Reseña ecológica de los bosques mediterráneos de Chile. Bosque 4(2):117-146.

Espinoza G, Gutiérrez JR, Hajek ER (1979) Gradiente latitudinal de las temperaturas máximas, mínimas y medias en Chile. Anales Museo de Historia Natural de Valparaíso 12:77-82.

Fernández DA, Santamarina PE, Tellería MC, Palazzesi L, Barreda VD (2016) Pollen morphology of Nothofagus (Nothofagaceae, Fagales) and its phylogenetic significance. Acta Palaeobotanica $56(2): 223-245$.

Fontana SL, Bennett KD (2012) Postglacial vegetation dynamics of western Tierra del Fuego. The Holocene 22(11):1337-1350.

Fuenzalida, H (1982) A country of extreme climate. Chile: Essence and Evolution. In: García H (ed) Instituto de Estudios Regionales de la Universidad de Chile, 27-35.

Gardner MF, Hechenleitner P, Thomas P, et al (2006). Threatened Plants of Central and South Chile. Distribution, Conservation and Propagation. First English edition. Universidad Austral de Chile and Royal Botanic Garden Edinburgh. 188 pp.

Garreaud RD, Vuille M, Compagnucci R, Marengo J (2008) Present-day South American climate.

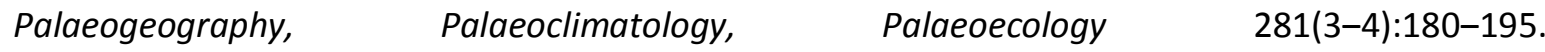
doi:10.1016/j.palaeo.2007.10.032

Grimm AM, Tedeschi RG (2009) ENSO and extreme rainfall events in South America. Journal of Climate 22:1589-1609.

Heenan PB, Smissen RD (2013) Revised circumscription of Nothofagus and recognition of the segregate genera Fuscospora, Lophozonia, and Trisyngyne (Nothofagaceae). Phytotaxa 146(1):1-31.

Heusser L, Heusser C, Mix A, McManus J (2006) Chilean and Southeast Pacific paleoclimate variations during the last glacial cycle: directly correlated pollen and $\delta^{18} \mathrm{O}$ records from ODP Site 1234. Quaternary Science Reviews 25:3404-3415. 
Heusser CJ (1984) Late-Glacial-Holocene climate of the Lake District of Chile. Quaternary Research 22:77-90.

Heusser CJ (1983) Quaternary pollen record from Laguna de Tagua Tagua, Chile. Science 29(4591):1429-1432.

Heusser CJ (1971) Pollen and Spores of Chile. Arizona: University of Arizona Press.

Hill RS, Read J (1991) A revised infrageneric classification of Nothofagus (Fagaceae). Botanical Journal of the Linnean Society 105:37-72.

Huber A (1977) Aporte a la climatología y climaecología de Chile. Parte 2: Nubosidad y radiación efectiva. Medio Ambiente 3(1):3-14.

Hulton NRJ, Purves RS, McCulloch RD, Sudgen DE, Bentley MJ (2002) The Last Glacial Maximum and deglaciation in southern South America. Quaternary Science Reviews 21:233-241.

Jaksic FM (1998) The multiple facets of El Niño/Southern Oscillation in Chile. Revista Chilena de Historia Natural 71:121-131.

Kottek M, Grieser J, Beck C et al (2006) World Map of the Köppen-Geiger climate classification updated. Meteorologische Zeitschrift 15(3):259-263.

Iglesias V, Quintana F, Nanavati W et al. (2016) Interpreting modern and fossil pollen data along a steep environmental gradient in northern Patagonia. The Holocene 27(7):1008-1018. DOI: $10.1177 / 0959683616678467$.

Iglesias V and Whitlock C (2014) Fire responses to postglacial climate change and human impact in northern Patagonia $\left(41^{\circ}-43^{\circ} \mathrm{S}\right)$. Proceedings of the National Academy of Science 111(51):55455554.

Iglesias V, Whitlock C, Markgraf V, Bianchi MM (2014) Postglacial history of the Patagonian forest/steppe ecotone (41-43으. Quaternary Science Reviews 94:120-135.

Iglesias, V. 2013. Holocene climate-vegetation-fire linkages along the Patagonian forest/steppe ecotone $\left(41-43^{\circ} \mathrm{S}\right)$. Doctoral dissertation. Montana State University, Bozeman, Montana, USA.

Iglesias V, Whitlock C, Bianchi MM, Villarosa G, Outes V (2012) Climate and local controls of longterm vegetation dynamics in northern Patagonia (Lat $41^{\circ} \mathrm{S}$ ). Quaternary Research 78:502-512. 
Iglesias V, Whitlock C, Bianchi MM, Villarosa G, Outes V (2011) Holocene climate variability and environmental history at the Patagonian forest/steppe ecotone: Lago Mosquito (42 $29^{\prime} 37.89^{\prime \prime S}$,

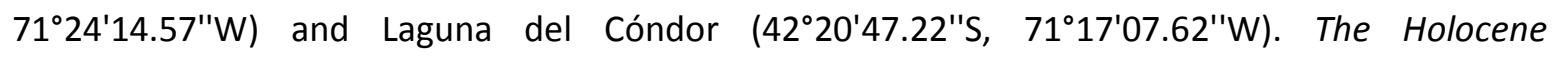
22(11):1297-1307.

Luebert F, Pliscoff P (2017) Sinopsis bioclimática y vegetacional de Chile. Editorial Universitaria.

McCulloch RD, Bentley MJ, Purves RS, Hulton NRJ, Sugden DE, Clapperton CM (2000) Climatic inferences from glacial and palaeoecological evidence at the last glacial termination, southern South America. Journal of Quaternary Science 15:409-417.

Marchant M, Cecioni A, Figueroa S et al. (2007) Marine geology, oceanography and climate. In: Moreno T, Gibbons W (eds) The Geology of Chile. The Geological Society. London. pp. 289-308.

Marchelli P, Caron H, Azpilicueta MM, Gallo LA (2007) Primer Note: A New Set of Highly Polymorphic Nuclear Microsatellite Markers for Nothofagus nervosa and Related South American Species. Silvae Genetica 57(2):82-85.

Marchelli P, Gallo LA (2004) The combined role of glaciation and hybridization in shaping the distribution of genetic variation in a Patagonian southern beech. Journal of Biogeography 31:451460.

Marchelli P, Gallo LA, Scholz F, Ziegenhagen B (1998) Chloroplast DNA markers reveal a geographical divide across Argentinean southern beech Nothofagus nervosa (Phil.) Dim. et Mil. distribution area. Theoretical and Applied Genetics 97:642-646.

Markgraf V, Whitlock C, Anderson RS, García A (2009) Late Quaternary vegetation and fire history in the northernmost Nothofagus forest region: Mallín Vaca Lauquen, Neuquén Province, Argentina. Journal of Quaternary Science 24(3):248-258.

Markgraf V, Webb RS, Anderson KH, Anderson L (2002) Modern pollen/climate calibration for southern South America. Palaeogeography, Palaeoclimatology, Palaeoecology 181:375-397.

Markgraf V (1991) Younger Dryas in southern South America? Boreas 20:63-69.

Markgraf V (1987). Paleoenvironmental changes at the northern limit of the subantarctic Nothofagus forests, lat. $37^{\circ} \mathrm{S}$, Argentina. Quaternary Research 28:119-129. 
Markgraf V, Bradbury JP, Fernández J (1986) Bajada de Rahue, Province of Neuquen, Argentina: an interstadial deposit in northern Patagonia. Palaeogeography, Palaeoclimatology, Palaeoecology $56: 251-258$.

Markgraf V (1983) Late and Postglacial vegetational and paleoclimatic changes in subantarctic, temperate, and arid environments in Argentina. Palynology 7:43-70.

Markgraf V and D’Antoni HL (1978) Pollen Flora of Argentina. Arizona: University of Arizona Press.

Montecinos A, Aceituno P (2003) Seasonality of the ENSO-related rainfall variability in Central Chile and associated circulation anomalies. Journal of Climate 16:281-296.

Moreira-Muñoz A (2011) Plant Geography of Chile. In: MJA Werger (ed). Plant and vegetation 5. Springer.

Moreno PI, Videla J, Valero-Garcés B, Alloway BV (2018) A continuous record of vegetation, fireregime and climatic changes in northwestern Patagoia spanning the last 25000 years. Quaternary Science Reviews 198:15-36.

Paredes M (2003) Caracterización genética de poblaciones de Nothofagus obliqua (Mirb.et Oerst) y Nothofagus alpina (Poepp. et Endl.) Oerst. (=N. nervosa (Phil.) Dim. et Mil.) mediante marcadores moleculares e isoenzimáticos. Informe Técnico Final, Fondo regional de Tecnología Agropecuaria (FONTAGRO).

Quintana JM, Aceituno P (2012) Chnages in the rainfall regime along the extratropical west coast of South America (Chile): 30-43 S. Atmósfera 25(1):1-22.

Ramírez C, San Martín C, Oyarzún A, Figueroa H (1997) Morpho-ecological study on the South American species of the genus Nothofagus. Plant Ecology 130:101-109.

Sabatier Y, Azpilicueta M.A, Marchelli P et al. (2011) Distribución natural de Nothofagus alpina y Nothofagus obliqua (nothofagaceae) en Argentina, dos especies de primera importancia forestal de los bosques templados norpatagónicos. Boletín de la Sociedad Argentina de Botánica 46 (1-2):131138.

Schäbitz F (1991) Holocene vegetation and climate in southern Santa Cruz, Argentina. Bamberger Geographische Schriften 11:235-244. 
Schäbitz, F (1989) Untersuchungen zum aktuellen Pollenniederschlag und zur holozänen Klima- und Vegetationsentwicklung in den Anden Nord-Neuquéns, Argentinien. Bamberger Geographische Schriften 8. Bamberg, Germany.

Sauquet H, Ho SYW, Gandolfo MA, Jordan GJ et al (2012) Testing the Impact of Calibration on Molecular Divergence Times Using a Fossil-Rich Group: The Case of Nothofagus (Fagales). Systematic Biology 61(2):289-313.

Swenson U, Hill, RS, McLoughlin S (2001) Biogeography of Nothofagus supports the sequence of Gondwana break-up. Taxon 50:1025-1041.

Valencio DA, Sinito AM, Creer KM, Mazzoni MM, Alonso MS, Markgraf V (1985) Palaeomagnetism, sedimentology, radiocarbon age determinations and palynology of the Llao Llao area, southwestern Argentina (lat. $41^{\circ} \mathrm{S}$, long. $71^{\circ} 30^{\prime} \mathrm{W}$ ): palaeolimnological aspects. Quaternary of South America and Antarctic Peninsula 3:109-148.

Van Steenis CGGJ (1971) Nothofagus, key genus of plant geography, in time and space, living and fossil, ecology and phylogeny. Blumea 19:5-98.

Vargas-Ramirez L, Roche E, Gerrienne P, Hooghiemstra H (2008) A pollen-based record of late glacial-Holocene climatic variability in the southern lake district, Chile. Journal of Paleolimnology 39:197-217.

Veblen TT, Armesto JJ, Burns BR, Kitzberger T et al (1995) The coniferous forest of South America. In: Anderson FA (ed.) Coniferous Forest. Volume 6. Elsevier Science. pp. 701-725.

Vergara R, Gitzendanner MA, Soltis DE, Soltis PS (2013) Population genetic structure, genetic diversity, and natural history of the South American species of Nothofagus subgenus Lophozonia (Nothofagaceae) inferred from nuclear microsatellite data. Ecology and Evolution 4(12):2450-2471.

Vergara R (2011) Neutral and adaptive genetic structure of the South American species of Nothofagus subgenus Lophozonia. Natural history, conservation, and tree improvement implications. Ph.D. thesis dissertation.

Viale M, Bianchi E, Cara L et al (2019) Contrasting climates at both sides of the Andes in Argentina and Chile. Frontiers in Environmental Science 7:69.

Viale M, Garreaud R (2015) Orographic effects of the subtropical and extratropical Andes on upwind precipitating clouds. Journal of Geophysical Research: Atmospheres 120:4962-4974. 
Viale M, Nuñez MN (2011) Climatology of winter orographic precipitation over the subtropical central Andes and associated synoptic and regional characteristics. Journal of Hydrometeorology $12: 481-507$.

Villagrán C (1980) Vegetationsgeschichtliche und pflanzensoziologische Untersuchungen im Vicente Pérez Rosales Nationalpark (Chile). Dessertationes Botanicae 54. Ganter Verlag K.G. Germany.

Wang PL, Pu FT, Zheng ZH (2000) Pollen morphology of the genus Nothofagus and its taxonomic significance. Acta Phytotaxonomica Sinica 38(5):452-461.

Weinberger P, Ramirez C (1999). Sinecología de la regeneración natural del Raulí (Nothofagus alpina) Fagaceae, Magnoliopsida. Revista Chilena de Historia Natural 72:337-351.

Whitlock C Bianchi MM, Bartlein PJ, Markgraf V, Marlon J, Walsh M, McCoy N (2006) Postglacial vegetation, climate, and fire history along the east side of the Andes (lat $41-42.5^{\circ} \mathrm{S}$ ), Argentina. Quaternary Research 66:187-201. 
Chapter 8

Synthesis of the main research outcomes and conclusions 


\subsection{Vegetation history}

Three lacustrine sediment cores located nearby the Lácar basin within the Lanín National Park (Argentina) were analysed in order to reconstruct past vegetation history (Figure 34). The oldest core comes from Lake Vizcacha, capturing the last 11700 cal. yr BP, while the records from the Lake Bruja and Lake Avutarda encompasses the last 3600 and 2700 cal. yr BP, respectively. The pollen diagram from Lake Vizcacha shows that vegetation composition has changed gradually as well as abruptly over the course of the Holocene. The Early Holocene can be separated into three environmental settings documented by changes in the aquatic and terrestrial pollen as well as the sedimentology.

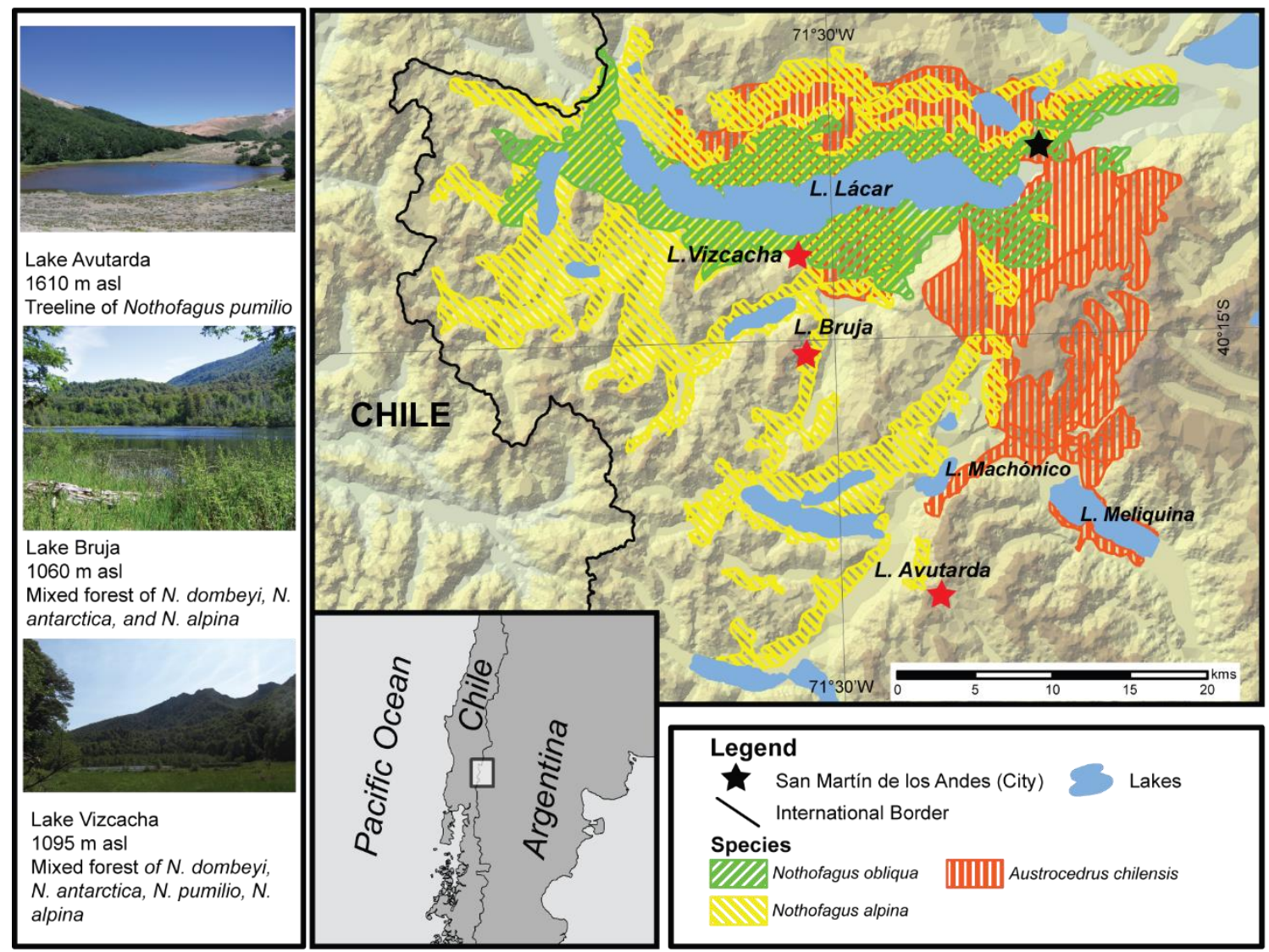

Figure 35. Map with the location of the study sites respect to the Lácar basin. Different colours represent the modern distribution of the species indicated in the legend, based on Administración de Parques Nacionales (2012); Sabatier et al. (2011) and Dezzotti and Sancholuz (1991).

Between 11700 and 10700 cal. yr BP, there is a high percentage of pollen from Cyperaceae and shrub taxa. This period correspond to a compact peat section with the presence of plant remains identified as Cyperaceae, Poaceae, and in minor proportion Sphagnum leaves together with woody 
trunks pieces. All these finding suggest the presence of a wetland dominated by Cyperaceae with shrubs most likely Nothofagus antarctica growing on the wetland. Pollen accumulation rate (PAR) during this period is low $\left(<15000\right.$ grain $\left.\mathrm{cm}^{-2} \mathrm{yr}^{-1}\right)$ and might suggest low vegetation cover around the site and an open Nothofagus woodland growing on the site. The low total PAR might, however, also be an artefact due to the bad preservation of the pollen grains and or a fast sedimentation rate not captured by the age model.

Today Lake Vizcacha persist due to high precipitation in winter and moderate during the spring and summer season. Reduced winter precipitation could therefore be a reason for the inexistence of the lake between 11700 and $10700 \mathrm{cal}$. yr BP. Based on pollen records located between $39^{\circ}$ and $43^{\circ} \mathrm{S}$ west of the Andes, Moreno et al. (2018) suggested low water levels and dry out of shallow lakes or lake regressive during the Early Holocene. However, the Early Holocene documented in Vizcacha indicated a shift to wetter conditions, as documented by the shift in sediment composition, the abrupt decline in Cyperaceae, and the presence of Myriophyllum after 10700 cal. yr BP. This indicates an interval of high precipitation during the Early Holocene, which triggered the development of a shallow lake flooding the Cyperaceae wetland, which explain its abrupt decline between 10700 and 9700 cal. yr BP and the appearance of Myriophyllum. During this humid interval, PAR's oscillate between 30000 and 60000 grains $\mathrm{cm}^{-2} \mathrm{yr}^{-1}$, and an increase in the percentage of Cupressaceae pollen is observed. Hitherto there is no other pollen record available at a similar latitude east of the Andes indicating similar patterns. West of the Andes, the pollen record from Caunahue (Markgraf, 1991) at the same latitude of Vizcacha did not show the presence of Cupressaceae but document an increase in warm-temperate taxa especially Weinmannia trichosperma, interpreted to indicate decreased precipitation and warmer temperatures. This opposite pattern of decreased precipitation likely represents local changes and /or edaphic conditions.

A renewed increase in Cyperaceae with a decline in Cupressaceae, Poaceae, the absence of Myriophyllum and the sediment change to peat after 9700 cal. yr BP, documents a renewed decrease in the water table of the lake, as a consequence of a decrease in precipitation. Nevertheless, the water table did not reach the same low stand as inferred for the time between 11700 and 10700 cal. yr BP since the percentage of Cyperaceae is the half of that in the former period.

From 8500 cal. yr BP onward the lithology is characterized by gyttja and the pollen record show low percentages of shrubs, Poaceae, and Cyperaceae, whereas Potamogeton and the green algae 
Botryococcus increase. These findings lead to the interpretation of a Mid-Holocene, characterized by the presence of a permanent lake, attributed to wetter conditions than before. The continuous but low presence of Nothofagus obliqua-type also characterize this period. Among the most noticeable patterns observed in this record is the $15 \%$ of Cupressaceae pollen between 8500 and 8000 cal. yr BP, which is concomitant with a decrease in $N$. dombeyi-type. In the literature, palynological records between $41^{\circ}$ and $43^{\circ} \mathrm{S}$ also show an increase in the percentage of Cupressaceae during the Mid-Holocene, attributed to Austrocedrus chilensis (Iglesias and Whitlock, 2014). The topmost samples of Vizcacha record document $<1 \%$ of Cupressaceae pollen, which is the signal of Austrocedrus populations located behind the mountains at the north facing slopes of Lake Lácar. As Austrocedrus has a restricted pollen dispersal (Markgraf et al., 1981), this high percentage during the Mid-Holocene might suggest the presence of a small population of this conifer nearby Vizcacha.

During the Late Holocene, major changes in vegetation composition were not observed in Bruja and Avutarda, except for the rise in the percentage of Nothofagus obliqua-type and the decline of Cupressaceae, attributed to Austrocedrus chilensis during this period. In Vizcacha, this pattern is also observed for the Late Holocene, suggesting a regional expansion of Nothofagus obliqua-type populations. The timing of the rise of this pollen type is similar in Bruja and Vizcacha. Both records documented a rise in the percentage of N. obliqua at 2200 cal. yr BP. In Avutarda the rise occurred later, at 1100 cal. yr BP.

According to Sabatier et al. (2010), the population of Nothofagus alpina around the Lácar basin occurs between 800 and $1150 \mathrm{~m}$ a.s.l., although in some sites isolated individuals have been observed at $1350 \mathrm{~m}$ a.s.I. Between 800 and $950 \mathrm{~m}, \mathrm{~N}$. alpina occurs in sympatry with N. obliqua. Generally, N. obliqua occurs at lower elevations, between 650 and 800 m a.s.I. As Vizcacha, Bruja, and Avutarda are located at high elevations, it is likely that Nothofagus alpina is contributing the most to the N. obliqua pollen type documented on the three records.

In order to compare the three records, a Principal Component Analysis was performed. The first and second axes explain $36 \%$ and $19 \%$ of the variance respectively. Figure 35 shows the samples/species bi-plot indicating that the samples from lake Avutarda and Bruja are located at the extremes, arranged on the first axis. The samples from Avutarda are dominated by steppe indicator taxa such as Poaceae, Discaria, and Ranunculus while the samples from lake Bruja are characterized by $N$. obliqua, Weinmannia trichosperma and Ericaceae. All these features suggest 


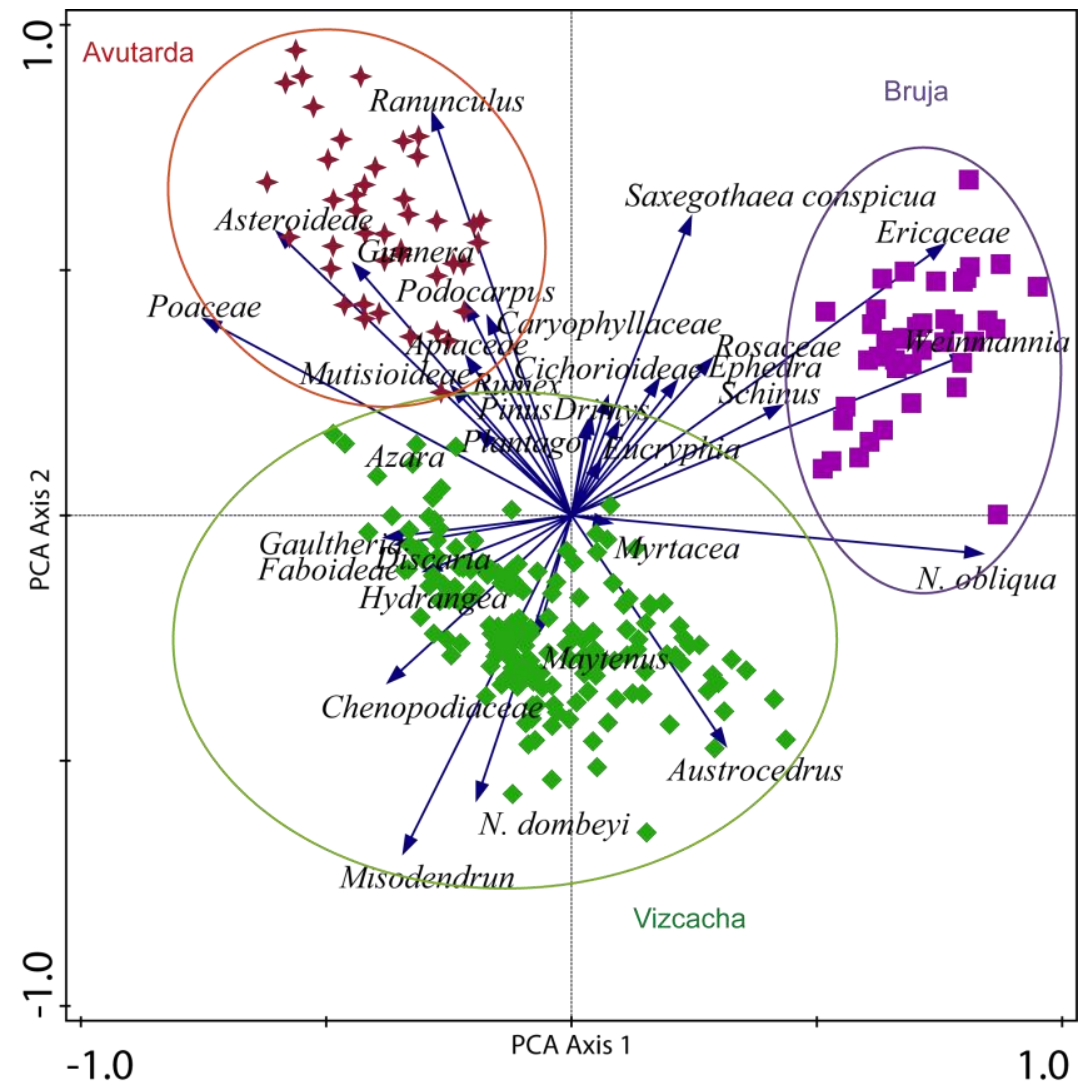

Figure 36. Species/samples scores of the PCA of pollen percentage data of Avutarda, Bruja, and Vizcacha.

that the first axis is representing an environmental gradient separating the samples from steppe and forest environments. In this gradient Bruja represents the most forested site and Avutarda the one in more open vegetation types, with the samples from Lake Vizcacha arranged in between. The second axis captures variance of Austrocedrus, N. dombeyi, Misodendrum, and Chenopodiaceae, which are all higher at Vizcacha separating this site along the second axis. Within the samples of Vizcacha a clear separation is observed between samples characterized by steppe indicator taxa such as Gaultheria, Discaria, and Chenopodiaceae and those samples characterized by forest indicators such as N. dombeyi, Misodendrum and Austrocedrus. This pattern agrees with the left-toright environmental gradient associated to the first axis. However, the comparison of the sites in the ordination documents that there are no major changes in vegetation composition throughout the Late Holocene in Avutarda Bruja and Vizcacha. For the last 4000 years, the three records are reflecting stable forest composition. 


\subsection{Postglacial history of Nothofagus obliqua-type}

One purpose of the present work was to analyse the past vegetation history of Nothofagus obliquatype. The three lakes analysed are located within the main population of Nothofagus obliqua and Nothofagus alpina (pollen type N. obliqua) in Argentina (Sabatier et al., 2011). Lake Avutarda and Lake Bruja document the increase of the pollen type over the Late Holocene period, while Vizcacha allows a long-term comparison. A visual comparison of the $N$. obliqua-type percentages for the three lakes (Figure 36) indicates an increase of the pollen type at $2200 \mathrm{cal}$. yr BP and $1100 \mathrm{cal} . \mathrm{yr}$ BP. In Vizcacha the first pollen grain observed dates to $11200 \mathrm{cal}$. yr BP. Later, at 7300 and at $2700 \mathrm{cal}$. yr BP local peaks (4.2\% and 6.4\%, respectively) are observed. However, the major rise started at 2200 cal. yr BP with an increase to $11 \%$ reaching a maximum of $17 \%$ at 400 cal. yr BP.

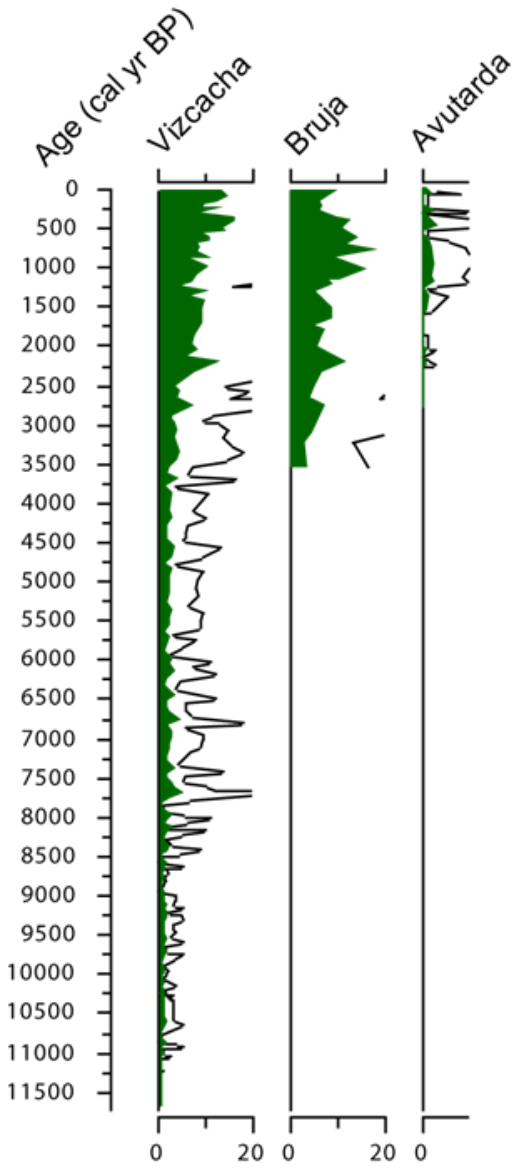

Figure 37. Comparison of the percentage of $N$. obliqua-type on Lake Avutarda, Bruja, and Vizcacha.
In most of the palynological records with the presence of $N$. obliqua-type, the pollen type is associated to warm and temperate climatic conditions (Abarzúa et al., 2014; Vargas-Ramírez et al., 2008). Markgraf et al. (2009) associate the rise in N. obliqua-type in the record from Mallín Vaca Lauquen $\left(35^{\circ} 51^{\prime} \mathrm{S} ; 71^{\circ} 02^{\prime} \mathrm{W}\right.$, Argentina) to the establishment of the present day winter rain/summer drought regime in the Late Holocene.

Based on 30 records with the presence of $N$. obliqua type from southern South America (Figure 37), a rapid expansion of the Nothofagus obliqua-type forest can be observed after the LGM. It has been proposed that $N$. obliqua-type forest survived in the South in ice-free areas during the LGM, such as the Coastal Cordillera and the Central Valley of Chile (Villagrán, 2000; Villagrán et al., 1998).

Several trees including Austrocedrus chilensis (Pastorino and Gallo, 2002) and Araucaria araucana (Marchelli et al., 2009) may also have survived the LGM east of the Andes, however if Nothofagus 
obliqua or alpina were among them is uncertain. Based on the results obtained, the major spread of Nothofagus obliqua-type forest in the region between $39^{\circ}$ and $41^{\circ} \mathrm{S}$ occurred between the Midand Late Holocene (see Figure 37). The major percentage of $N$. obliqua-type during the MidHolocene come from the moor Derrumbes located within the Vicente Pérez Rosales National Park, Chile $\left(41^{\circ} 09^{\prime} \mathrm{S} ; 72^{\circ} 06^{\prime} \mathrm{W}\right.$; Villagrán 1980$)$ with $60 \%$ of the pollen type. The author interprets this high percentage as a consequence of a warm and dry climate during this period. Today, neither Nothofagus obliqua, nor Nothofagus alpina occur at those latitudes in south Chile and Argentina. Therefore, its absence during the Late Holocene has been attributed to a northward displacement of the populations (Villagrán, 1980; 1991).

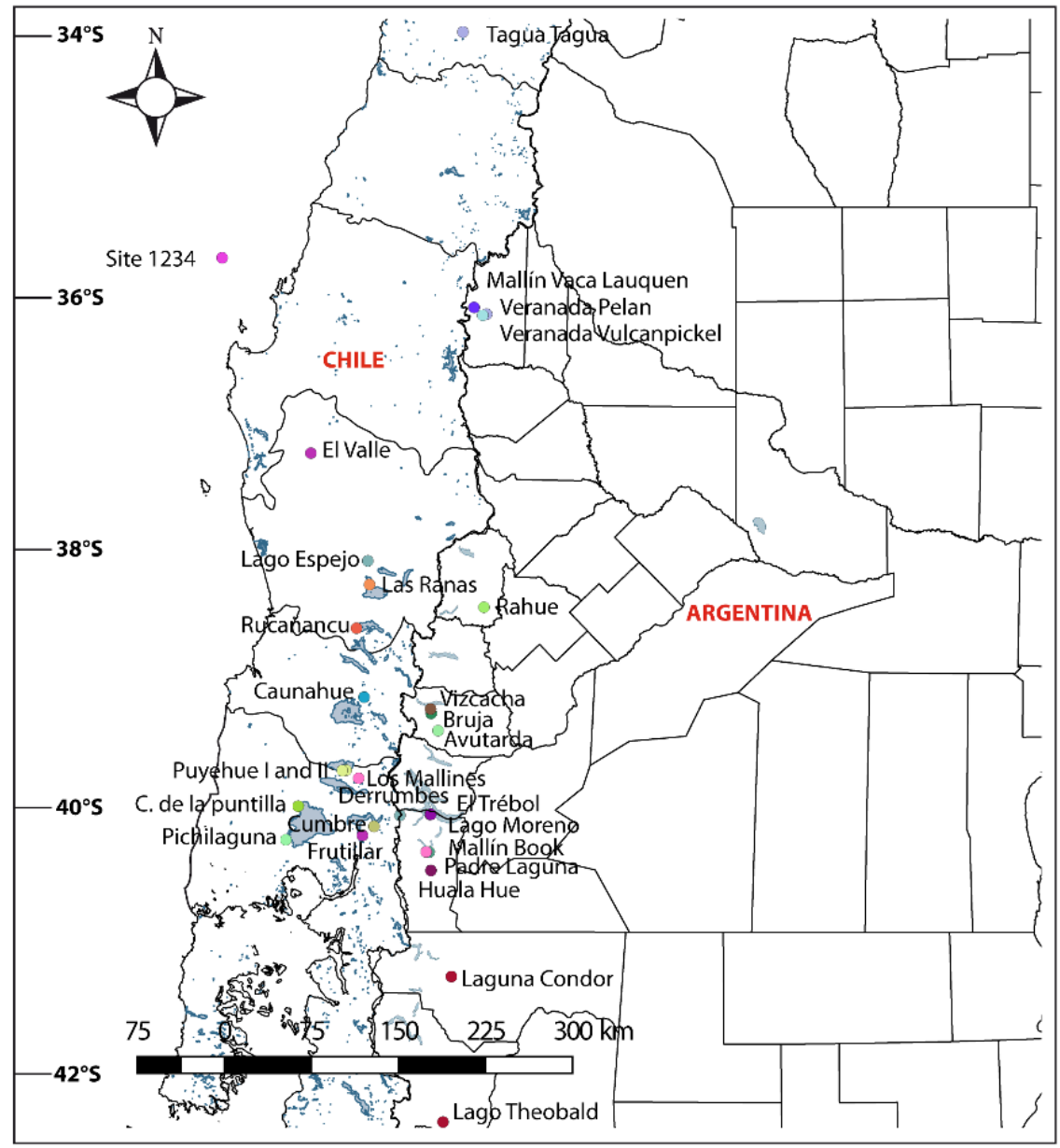

Figure 38. Map with the location of the sites analysed with the presence of Nothofagus obliqua-type. 
High percentages were observed in sites located within the Central Valley and the Andes, such as Lago Espejo, Las Ranas, Rucañancu $\left(38^{\circ} \mathrm{S}\right)$, and Vizcacha, Bruja, Puyehue I and II (40 $\left.\mathrm{S}\right)$. Percentages $<1 \%$ observed since the LGM to present times in sites in the north of the study areas such as Veranada Pelan and Vulcanpickel, as well as in sites towards the south (from El Trébol to Lago Theobald in Argentina) are interpreted as a long-distance pollen signal from dense populations located within the Central Valley and Andes.

Overall, the warming pulse suggested after the LGM, allowed the expansion of both Nothofagus obliqua and Nothofagus alpina. Since the Mid-Holocene, sites located the Central Valley of Chile, especially those at $38^{\circ} \mathrm{S}$ (see Figure 38 ) indicate a variable but continue presence of the pollen type due to the stable warmer and temperate climatic conditions inferred for that period (Figure 38). Already during the Late Holocene, the modern geographical location of the population of both deciduous trees was somehow established in the region. Nevertheless, during the last 200 years, it has been reported a substantial decrease in both populations due to human activities related to timber extraction, the introduction of exotic species (e.g. Pinus and Eucalyptus), and crop cultivation. Finally, the rapid expansion of both species during the inferred warming pulses in the Deglacial and Mid-Holocene periods reflects the sensitive and fast response of Nothofagus obliqua and Nothofagus alpina to the drastic changes in climatic conditions in the region. 


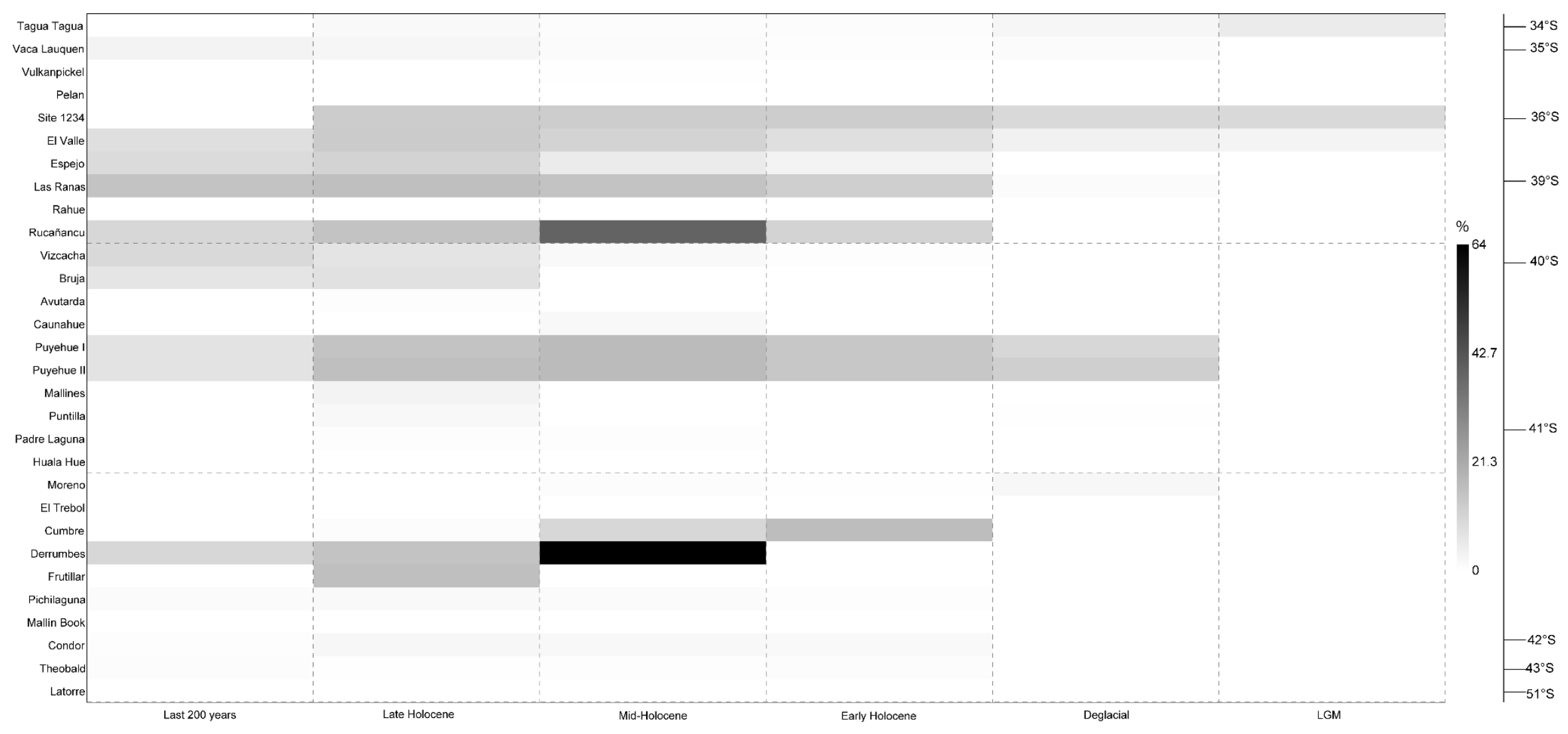

Figure 39. Matrix plot with the changes in the percentage of $N$. obliqua-type through time in grey scale. The sites are arranged from north (top) to south (bottom). 


\subsection{Influence of ash deposition on the vegetation}

The presence of several tephra layers in the three cores documents the frequent volcanic activity in the region. For the last 11700 cal. yr BP the Vizcacha core includes 27 tephra layers; Bruja (3600 cal. yr BP) recorded 46 tephra layers; and Avutarda (2700 cal. yr BP) contains 22 tephra layers. Unfortunately, the tephra layers in the three cores could not be matched visually. Tephra layers > $20 \mathrm{~cm}$ were found in the three cores and their deposition on the landscape around the lakes should have impacted the vegetation.

Through a redundancy analysis, the influence of ash deposition on the vegetation was assessed and the results indicated no significant influence of ash on the vegetation. Nevertheless, the percentage of some herbaceous and shrub taxa along with Nothofagus dombeyi-type decrease slightly after the deposition of tephra $>20 \mathrm{~cm}$, but this pattern seems to be random in the three cores analysed. Independently of the thickness of the tephra, the percentage of some taxa such as $N$. dombeyi, Poaceae, and Misodendrum did not show a decrease with the deposition of tephra $>30 \mathrm{~cm}$. Likely, at the time of the tephra deposition other disturbance agents such a fire or climatic forces triggered the changes in vegetation, or they could have acted together. Therefore, it is difficult to associate solely with ash deposition the changes in plant communities.

Certainly, the distance from the volcano and the tephra thickness are variables to take into account to assess the influence of this disturbance agent on the vegetation. For example, the vegetation closer to the Hudson, Chaitén, and Puyehue volcanoes (Chile) were severely affected at the time of the eruption, while areas hundreds of meters away were less damaged (González et al., 1996). The authors described a high mortality of Nothofagus antarctica and Nothofagus pumilio after the eruption of the Hudson volcano in 1991 due to lahar and massive ash deposition by river flooding affecting trees. Trees of Nothofagus pumilio located hundred kilometers away from the volcano were covered with up to $1 \mathrm{~m}$ of tephra but survived while the evergreen Nothofagus dombeyi showed foliage damage. The persistence of some Nothofagus species after volcanic disturbance might be attributed to certain biological adaptations, such as the formation of adventitious roots from the branches on those trees covered by a thick ash layer (Nothofagus antarctica, Veblen et al., 1977) or by the development of a new root system at the height of the new soil surface (Nothofagus pumilio, Veblen et al., 1977).

Apart from the biological adaptations that some Nothofagus species possess, the fact that the Nothofagus genus is a large pollen producer cannot be dismissed. Therefore, a possible local decline 
in Nothofagus, might be compensated by the influx of extra-local Nothofagus pollen, suppressing an effective local decline in vegetation driven by volcanism (Henríquez et al., 2015).

A decline in Poaceae percentage was observed, especially after the deposition of more than $20 \mathrm{~cm}$ of tephra in the lakes Bruja and Avutarda and after the deposition of more than $50 \mathrm{~cm}$ in the Lake Vizcacha, but like in the case of Nothofagus dombeyi-type the decline in the percentage of herbaceous taxa occurs even after the deposition of tephra of minor thicknesses. It is known that some understory species are capable of resprouting and cross the ash layers, such as the fern Lophosoria and the bamboo Chusquea (González et al., 2014). The latter is an important component of the understory present around Lake Bruja and Lake Vizcacha and probably the changes in the percentage of Poaceae pollen could be related to the dynamic of the bamboo Chusquea.

In summary, vegetation burial by volcanic ash did not induce a statistically significant effect on the local vegetation nearby Lake Avutarda, Bruja, and Vizcacha. The presence of other disturbance agents, the timing of the eruption, climatic conditions, and biological adaptations of some species to burial, might explain the random changes in the percentage of some taxa observed in the three records. Nevertheless, the time resolution of the samples analysed ( $70 \mathrm{yrs}$ ) might hide short-term vegetation responses to volcanic disturbance that are therefore unnoticeable in the pollen record. Modern observations regarding the effect of ash deposition on the vegetation in the region include canopy damage, a slow vegetative growth after disturbance, and a decline in flowering.

\subsection{Fire History}

The presence of macro charcoal particles $(\geq 125 \mu \mathrm{m})$ in Vizcacha and Bruja cores account for the local occurrence of fire during the full Holocene and Late Holocene respectively. The Early Holocene documented in Vizcacha indicate values $<2.5$ pieces $\mathrm{cm}^{-2} \mathrm{yr}^{-1}$, with a peak at 10200 cal. yr BP (5.5 pieces $\mathrm{cm}^{-2} \mathrm{yr}^{-1}$ ). In addition, the CHAR background is $<0.8$ pieces $\mathrm{cm}^{-2} \mathrm{yr}^{-1}$ between 11700 and 10100 cal. yr BP with a shift to 1.1 pieces $\mathrm{cm}^{-2} \mathrm{yr}^{-1}$ between 10100 and 9500 cal. yr BP. Records from west Andes indicate values around 2.5 pieces $\mathrm{cm}^{-2} \mathrm{yr}^{-1}$ for the Early Holocene at $40^{\circ} \mathrm{S}$ (Jara and Moreno, 2014) with some peaks of 5 pieces $\mathrm{cm}^{-2} \mathrm{yr}^{-1}$. Whitlock et al. (2006) analysed mid-latitudes lakes in Argentina $\left(41^{\circ}-42.5^{\circ} \mathrm{S}\right)$ indicating CHAR values $<2$ pieces $\mathrm{cm}^{-2} \mathrm{yr}^{-1}$ for the Early Holocene. Based this comparison, moderate local fires occurred during the Early Holocene in Vizcacha. As it was inferred, likely the dry and warm conditions suggested for the Early Holocene contribute with enough fuel to 
support surface fires. Nevertheless, in Vizcacha fires could have also affected shrubland inferred by the presence of wood charred particles during this period.

The Mid-Holocene was characterized by a shift from low-moderate fires to fires of high magnitude. According to Whitlock et al. (2006) the magnitude is an indicator of the intensity or size of the fire. Based on this, severe fires occurred especially between 7000 and 5500 cal. yr BP. Increased fire activity at the beginning of the Mid-Holocene is recorded by Jara and Moreno (2014) for the time between 8000 and 6700 cal. yr BP with a sharp decrease immediately after 6000 cal. yr BP. Similar to Vizcacha, the site El Trébol (Whitlock et al., 2006; $41^{\circ} \mathrm{S}$, Argentina) documented high fire magnitudes between $\sim 6500$ and $\sim 5500$ cal. yr BP. Fire free intervals are longer between 7000 and 5000 cal. yr BP (300 year fire ${ }^{-1}$ ), which in turn result in accumulation of biomass that given the proper climatic and ignition conditions, may result in severe fires. This pattern seems to explain the magnitudes of the fires detected during the Mid-Holocene in Vizcacha. Peaks in CHAR support this interpretation.

As Bruja only documents the last 3600 cal. yr BP, Figure 39 shows a summary of the main fire component of both lakes for the same time period in order to analyse patterns on fire regimes. Between 3600 and 2000 cal. yr BP, CHAR and CHAR background values are negligible in Bruja and only a small peak in fire magnitude was detected in Bruja at 3400 cal. yr BP. On the other hand, for the same time period Vizcacha present low values in $\mathrm{CHAR}\left(<0.8\right.$ pieces $\left.\mathrm{cm}^{-2} \mathrm{yr}^{-1}\right)$ which suggest low biomass burning, therefore low severity fire. Nevertheless, as Vizcacha is located at higher elevation than Bruja, it cannot be dismissing the possibility that these low CHAR values in Vizcacha correspond partially to extra-local fire signal from fires occurring at dry slopes of the Lácar basin.

The last 2000 years are characterized by a shift from low or negligible fire activity to moderate fires in Bruja, based on the substantial increase in CHAR values (2-12 pieces $\left.\mathrm{cm}^{-2} \mathrm{yr}^{-1}\right)$ as well as in the increased fire frequency. Meanwhile, Vizcacha continue recording low or negligible fires $(<1$ piece $\mathrm{cm}^{-2} \mathrm{yr}^{-1}$ ) and fire frequency decline (see Figure 40). Dissimilarities in fire signal between these two sites located only $4 \mathrm{~km}$ apart might be attributed to vegetational differences between the two sites. The vegetation around lake Bruja is more open, with patches of grass, and surrounded by shrubland of Nothofagus antarctica at lower slopes. In contrast, Lake Vizcacha is located between two mountains; it is surrounded by an old and closed Nothofagus forest, and next to a wetland dominated by Cyperaceae and Poaceae. Shrublands of Nothofagus antarctica have been defined as fire-prone (Veblen et al., 2008), while tall forest represents an obstacle for vertical continuity of the 
fire due to coarser moister fuel (Mermoz et al., 2005). These facts could explain why Bruja is documenting severe fires in comparison with Vizcacha during the last 2000 years.

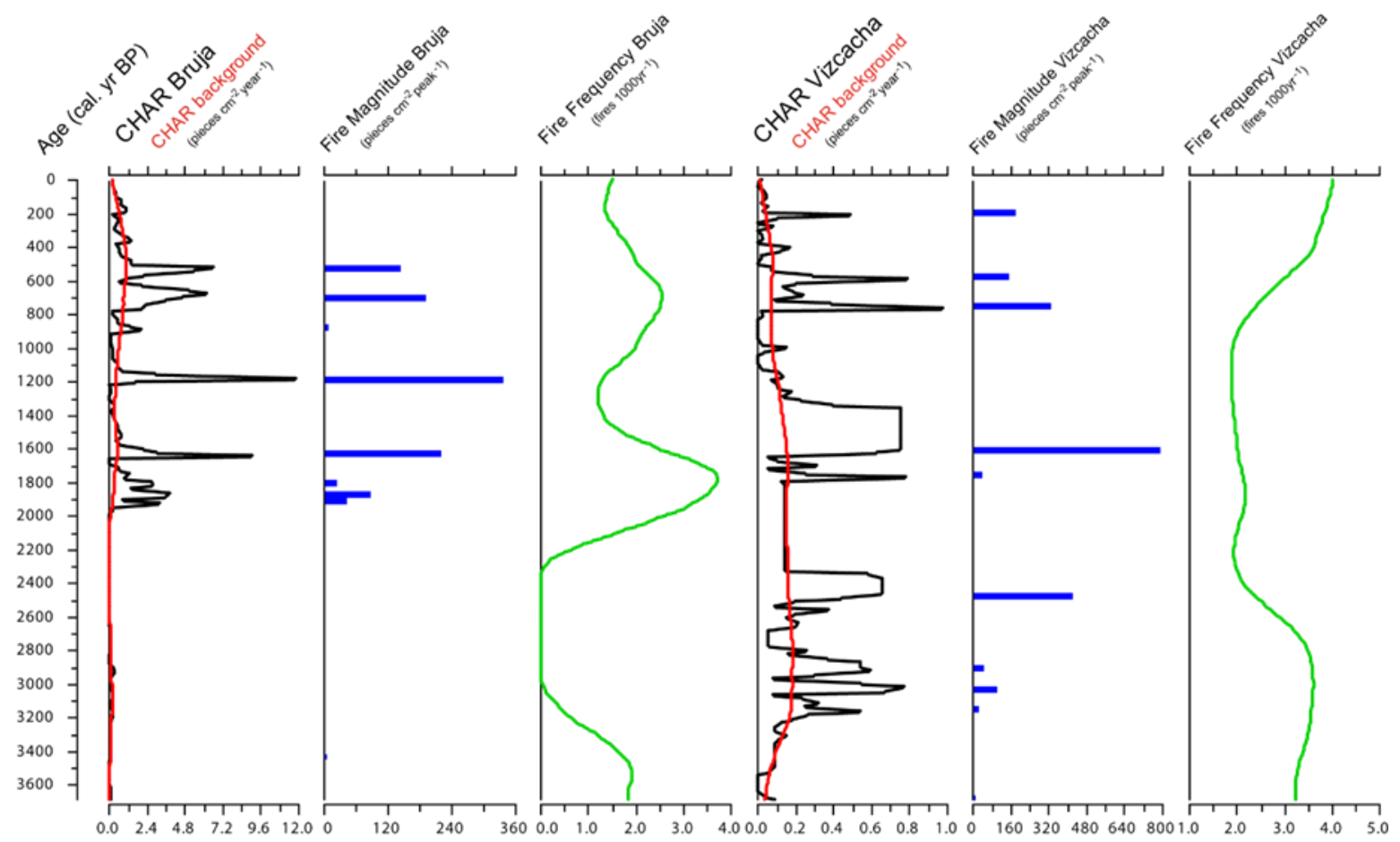

Figure 40. Summary of the main fire components documented in Bruja and Vizcacha core for the last 3600 cal. yr BP.

Finally, regarding the possible effect of fire on vegetation changes, the RDA results in Bruja indicated a nonsignificant influence of fire frequency and fire magnitude on the vegetation composition and the variables explained only 4.4 and $3.4 \%$ of the variation. Nevertheless, since in this record contiguous pollen sampling was conducted only before and after major tephra layers it may be possible that the response of the vegetation to fire was not detected in other sections of the core. Despite this, it is possible to suggest that the local fire signal captured by Lake Bruja corresponds to surface- to moderate-fires, at low magnitude and possibly promoted by lightning.

In Vizcacha, the fire return interval (FRI) showed a positive correlation with Austrocedrus chilensis ( $p=0.002$ ). Low percentages of Austrocedrus were documented for the Early Holocene, except for the slight increase during the humid phase inferred between 10700 and $9700 \mathrm{cal}$. yr BP. Again, during the humid phase after $8500 \mathrm{cal}$. yr BP Austrocedrus reached the highest percentage (15\%) documented for the entire period, concomitant with low fire frequency, negligible fire magnitude and longer-than-before FRI. Under this scenario, those more humid conditions reported at the 
beginning of the Mid-Holocene could have prevented vegetation ignition and therefore, a decline in fire events, expressed as long fire-free intervals which may have benefited Austrocedrus.

\subsection{Conclusions}

To conclude, the three records analysed document a stable Nothofagus forest during the Late Holocene. The Vizcacha record shows a high percentage of Nothofagus dombeyi-type along the entire record with some fluctuations in its percentage. This might be related to changes in climatic conditions during the Holocene. Addittionally, variation in the percentage of shrubs and herbs may be related to changes in the forest canopy. On the other hand, Nothofagus obliqua-type appears in the Vizcacha record around $11200 \mathrm{cal}$. yr BP, but a major increase of this pollen type occurs during the Late Holocene suggesting the establishment of both, Nothofagus alpina and Nothofagus obliqua during this period. Based on the modern ecology and distribution of both species, likely Nothofagus alpina is contributing the most to this pollen type. Precipitation seasonality and dry summers might explain somehow the establishment of these deciduous southern beech species in the Late Holocene. On the possible influence of ash deposition on the vegetation composition, the analyses carried out indicate no statistically significant influence of this disturbance mechanism. Nevertheless, in some cases was observed a decrease in the percentage of certain taxa, especially herbaceous after the deposition of more than $10 \mathrm{~cm}$ of tephra. Regarding fires, they do not play an important role in the local vegetation recorded in Bruja during the Late Holocene. However, fires might have influenced the dynamics of Austrocedrus chilensis populations nearby lake Vizcacha, especially during the Mid-Holocene. Finally, anthropogenic disturbance seems to play an important role in the diminish in the percentage of Nothofagus-obliqua-type, especially during the last 200 years, associated with the overexploitation of Nothofagus obliqua and Nothofagus alpina around the Lácar basin. However, after the creation of the Lanín National Park (1937), these activities were regulated, contributing to the maintenance of both deciduous trees within the basin. The decline in fire magnitude observed in Bruja and Vizcacha core during the last decades suggests effective fire suppression activities in the region. 


\section{References}

Administración de Parques Nacionales (2012) Plan de Gestión Parque Nacional Lanín. Tomo I: caracterización y diagnóstico.

Dezzotti A and Sancholuz L (1991) Los bosques de Austrocedrus chilensis en Argentina: ubicación, estructura, y crecimiento. Bosque 12(2):43-52.

Jara IA, Moreno PI (2014) Climatic and disturbance influences on the temperate rainforests of northwestern Patagonia $\left(40^{\circ} \mathrm{S}\right)$ since $\sim 14,500$ cal yr BP. Quaternary Science Reviews 90:217-228.

Marchelli P, Baier C, Mengel C, Ziegenhagen B, Gallo LA (2008) Biogeographic history of the threatened species Araucaria araucana (Molina) K. Koch and implications for conservation: a case study with organelle DNA markers. Conservation Genetics 11:951-963.

Markgraf V (1991) Younger Dryas in southern South America? Boreas 20:63-69.

Mermoz M, Kitzberger T, Veblen TT (2005) Landscape influences on occurrence and spread of wildfires in Patagonian forest and shrublands. Ecology 86(10):2705-2715.

Moreno PI, Videla J, Valero-Garcés B, Alloway BV (2018) A continuous record of vegetation, fireregime and climatic changes in northwestern Patagoia spanning the last 25000 years. Quaternary Science Reviews 198:15-36.

Pastorino MJ, Gallo LA (2002) Quaternary evolutionary history of Austrocedrus chilensis, a cypress native to the Andean-Patagonian forest. Journal of Biogeography 29:1167-1178.

Sabatier Y, Azpilicueta M.A, Marchelli P et al. (2011) Distribución natural de Nothofagus alpina y Nothofagus obliqua (nothofagaceae) en Argentina, dos especies de primera importancia forestal de los bosques templados norpatagónicos. Boletín de la Sociedad Argentina de Botánica 46 (1-2):131138.

Van Geel B, Aptroot A (2006) Fossil ascomycetes in Quaternary deposits. Nova Hedwigia 82(34):313-329.

Veblen TT, Kitzberger T, Raffaele E et al. (2008) The historical range of variability of fires in the Andean-Patagonian Nothofagus forest region. International Journal of Wildland Fire 17:724-741.

Villagran C (2000) Historia de la vegetación de las cimas de la Cordillera de la Costa, región de Los Lagos, Chile. IX Congreso Geológico Chileno (31 Julio-4 Agosto, Puerto Varas, Chile). Actas 1 Sesión temática 3 pp. 578-582.

Villagrán C, Le Quesne C, Aravena JC, Jiménez H, Hinojosa F (1998) El rol de los cambios de clima del Cuaternario en la distribución actual de la vegetación de Chile central-sur. Bamberger Geographische Schriften 15:227-242.

Villagrán C (1991) Historia de los bosques templados del sur de Chile durante el Tardiglacial y Postglacial. Revista Chilena de Historia Natural 64:447-460.

Villagrán C (1980) Vegetationsgeschichtliche und pflanzensoziologische Untersuchungen im Vicente Pérez Rosales Nationalpark (Chile). Dessertationes Botanicae 54. Ganter Verlag K.G. Germany. 
Whitlock C Bianchi MM, Bartlein PJ, Markgraf V, Marlon J, Walsh M, McCoy N (2006) Postglacial vegetation, climate, and fire history along the east side of the Andes (lat $41-42.5^{\circ} \mathrm{S}$ ), Argentina. Quaternary Research 66:187-201. 


\section{Acknowledgements}

My Ph.D. studies would not be possible without the support of my mentor, Dra. Ana María Abarzúa, who taught me everything I know about palynology. Thank you so much for introducing me to the beautiful science of Palynology. I would like to thank Prof. Dr. Hermann Behling for accepting me as a member of his Department, and for allowing me to fight for my rights. I want also to thank Dr. Thomas Giesecke for continuing to help me with my research despite the obstacles. My gratitude goes also to Prof. Dr. Frank Schäbitz and Prof. Dr. Erwin Bergmeier for being my supervisor during the last stages of my doctoral studies.

Living in another country, with another language and culture it is not easy, but thanks to my friend Christina Setyaningsih and Daniela Piraquive my experience here was much better. Thank you for your friendship, trust, and support in good times and in bad. May this world bring to you only its best. My profound and sincere gratitude goes also to Ricardo Moreno G. Thank you for helping me and comforting me in my hardest moments, for your comments during the development of my research, and for allowing me to meet your beautiful family. All the best to you as well.

Finally, I would like to express my deepest gratitude to Ricardo Vega Neira, my beloved partner, and friend. We were lucky to achieve our dreams together, at the same University. Your support, advice, and love allowed me to continue and pursue my aims during my studies. It would not have been possible without you. 


\section{Declaration of Academic Integrity}

I hereby confirm that the present dissertation is solely the work of myself. All scientific collaborators appear as co-authors of the manuscripts. If any passages or figures/diagrams from books, papers, the Web or other sources have been copied or in any other way used, all references, including those found in electronic media, have been acknowledged and fully cited.

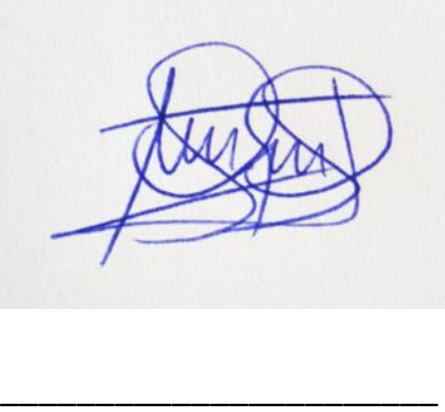

Valentina A. Álvarez Barra 


\section{Appendix 1}

Table of identified pollen, spores and NPP taxa 
Appendix 1: Table of identified pollen, spores and NPP taxa

Abbreviations for palynological records:

LA: Lake Avutarda (Chapter 5)

LB: Lake Bruja (Chapter 5)

LV: Lake Vizcacha (Chapter 6)

\begin{tabular}{|c|c|c|}
\hline Pollen type & Family & Records \\
\hline Nothofagus dombeyi-type & Nothofagaceae & LA LB LV \\
\hline Nothofagus obliqua-type & Nothofagaceae & LA LB LV \\
\hline Saxegothaeae conspicua & Podocarpaceae & LA LB LV \\
\hline Podocarpus nubigenus & Podocarpaceae & LA LB LV \\
\hline Cupressaceae & Cupressaceae & LA LB LV \\
\hline Araucaria araucana & Araucariaceae & LB \\
\hline cf. Monimiaceae & Monimiaceae & LV \\
\hline Myrtaceae & Myrtaceae & LA LB LV \\
\hline Alnus acuminata & Betulaceae & LA \\
\hline Lomatia hirsuta & Proteaceae & LA LB LV \\
\hline Weinmannia trichosperma & Cunoniaceae & LA LB LV \\
\hline Eucryphia/Caldcluvia & Cunoniaceae & LA LB LV \\
\hline Lauraceae & Lauraceae & LV \\
\hline cf. Cryptocaria & Lauraceae & LV \\
\hline Drimys winteri & Winteraceae & LA LB LV \\
\hline Pseudopanax & Araliaceae & LV \\
\hline Lepidoceras & Eremolepidaceae & LV \\
\hline Hydrangea & Hydrangeaceae & LA LB LV \\
\hline Misodendrum & Misodendraceae & LA LB LV \\
\hline Loranthaceae & Loranthaceae & LV \\
\hline cf. Griselinia & Griseliniaceae & LV \\
\hline Azara & Salicaceae & LA LB LV \\
\hline
\end{tabular}




\begin{tabular}{|c|c|c|}
\hline Maytenus & Celastraceae & LA LB LV \\
\hline Fuchsia & Onagraceae & LV \\
\hline Escallonia & Escalloniaceae & LB LV \\
\hline Embothrium coccineum & Proteaceae & LA LV \\
\hline Schinus patagonicus & Anacardiaceae & LA LB LV \\
\hline Philesia type & Philesaceae & LV \\
\hline Gaultheria & Ericaceae & LA LB LV \\
\hline Ribes & Grossulariaceae & LA LB LV \\
\hline Asteraceae subf. Asteroideae & Asteraceae & LA LB LV \\
\hline Asteraceae subf. Cichorioideae & Asteraceae & LA LB LV \\
\hline Mutisioideae undiff & Asteraceae & LA LB LV \\
\hline Mutisia & Asteraceae & LV \\
\hline Nassauvia & Asteraceae & LA LB LV \\
\hline Artemisia & Asteraceae & LV \\
\hline Senecio type & Asteraceae & LV \\
\hline cf. Ambrosia & Asteraceae & LV \\
\hline Perezia type & Asteraceae & LV \\
\hline Rosaceae & Rosaceae & LA LB LV \\
\hline Potentilla type & Rosaceae & LV \\
\hline Acaena & Rosaceae & LA LB LV \\
\hline Fragaria type & Rosaceae & LV \\
\hline Empetrum rubrum & Ericaceae & LA LB LV \\
\hline Discaria & Rhamnaceae & LA LB LV \\
\hline Rhamnaceae undiff & Rhamnaceae & LV \\
\hline Quinchamalium & Schoepfiaceae & LA LB LV \\
\hline Valeriana & Valerianaceae & LA LB LV \\
\hline Berberis & Berberidaceae & LA LB \\
\hline Viviania & Vivianiaceae & LA LB LV \\
\hline Wendtia & Ledocarpaceae & LV \\
\hline
\end{tabular}




\begin{tabular}{|c|c|c|}
\hline Armeria marítima & Plumbaginaceae & LA LV \\
\hline cf. Aristotelia & Elaeocarpaceae & LV \\
\hline Ovidia andina & Thymelaeaceae & LV \\
\hline Ephedra & Ephedraceae & LA LB LV \\
\hline Gomphrena & Amaranthaceae & LV \\
\hline Alstroemeria & Alstroemeriaceae & LV \\
\hline Poaceae & Poaceae & LA LB LV \\
\hline Iridaceae & Iridaceae & LA LB LV \\
\hline Adesmia & Fabaceae & LV \\
\hline Ranunculus & Ranunculaceae & LA \\
\hline Malvaceae & Malvaceae & LV \\
\hline Chenopodiaceae & Chenopodiaceae & LA LB LV \\
\hline Phacelia & Boraginaceae & LA LB LV \\
\hline Rubiaceae & Rubiaceae & LA LB LV \\
\hline Faboideae undiff & Fabaceae & LA LB LV \\
\hline Primula & Primulaceae & LV \\
\hline Vicia & Fabaceae & LV \\
\hline Lathyrus & Fabaceae & LV \\
\hline Brassicaceae & Brassicaceae & LV \\
\hline Apiaceae & Apiaceae & LA LB LV \\
\hline Osmorhiza & Apiaceae & LV \\
\hline Eryngium type & Apiaceae & LV \\
\hline Mulinum & Apiaceae & LA LV \\
\hline Azorella & Apiaceae & LA LB LV \\
\hline Polygonaceae & Polygonaceae & LA LV \\
\hline Caryophyllaceae & Caryophyllaceae & LA LB LV \\
\hline Campanulaceae & Campanulaceae & LV \\
\hline Verbenaceae & Verbenaceae & LA LB LV \\
\hline Gunnera & Gunneraceae & LA LB LV \\
\hline
\end{tabular}




\begin{tabular}{|c|c|c|}
\hline cf. Nertera & Rubiaceae & LV \\
\hline Litorella/Plantago & Plantaginaceae & LA LV \\
\hline Jaborosa type & Solanaceae & LV \\
\hline cf. Euphorbiaceae & Euphorbiaceae & LA LB LV \\
\hline Solanaceae & Solanaceae & LA LB LV \\
\hline cf. Convolvulaceae & Convolvulaceae & LA LV \\
\hline cf. Geraniaceae & Geraniaceae & LV \\
\hline cf. Gentianaceae & Gentianaceae & LV \\
\hline Rumex acetosella & Polygonaceae & LA LB LV \\
\hline Plantago lanceolata & Plantaginaceae & LA LB LV \\
\hline Pinus & Pinaceae & LA LB LV \\
\hline Sagittaria & Alismataceae & LV \\
\hline Myriophyllum & Halogaraceae & LV \\
\hline Isoëtes & Isoëtaceae & LA LB LV \\
\hline Triglochin & Juncaginaceae & LV \\
\hline Callitriche & Plantaginaceae & LV \\
\hline Potamogeton & Potamogetonaceae & LV \\
\hline Cyperaceae & Cyperaceae & LA LB LV \\
\hline Eleocharis type & Cyperaceae & LV \\
\hline Hydrocotyle & Araliaceae & LV \\
\hline Hymenophyllum & Hymenophyllaceae & LA LB LV \\
\hline Polypodium feuillei & Polypodiaceae & LA LB LV \\
\hline Lycopodium magellanicum & Lycopodiaceae & LV \\
\hline Blechnum & Blechnaceae & LV \\
\hline Polypodiaceae & Polypodiaceae & LA LB LV \\
\hline Lophosoria & Dicksoniaceae & LV \\
\hline Pteridophyte Trilete & & LV \\
\hline Anthoceros/Phaoceros & Anthocerotaceae & LA \\
\hline Sparganium & $\begin{array}{l}\text { Sparganiaceae o } \\
\text { Typhaceae sensu lato }\end{array}$ & LA LB \\
\hline
\end{tabular}




\begin{tabular}{|l|l|l|}
\hline NPP type & Family & Record \\
\hline Gelasinospora & Sordariaceae & LV \\
\hline Glomus & Glomeraceae & LV \\
\hline Microthyrium & Microthyriaceae & LV \\
\hline Conidiospore & & LV \\
\hline cf. Podospora & Lasiosphaeriaceae & LV \\
\hline Cercophora & Lasiosphaeriaceae & LV \\
\hline cf. Delitschia & Delitschiaceae & LV \\
\hline Coniochaeta HdV 172 & Coniochaetaceae & LV \\
\hline Pithomyces & Pleosporaceae & LV \\
\hline Dictyosporium & Dictyosporiaceae & LV \\
\hline Byssiothecium & & LV \\
\hline UG 1085 & & LV \\
\hline Rhabdocoela egg & LV \\
\hline Botryococcus & Lotryococcaceae & LV \\
\hline Pediastrum & Hydrodictyaceae & \\
\hline
\end{tabular}




\section{Appendix 2}

Pictures of some pollen and spores observed

*reference collection picture 

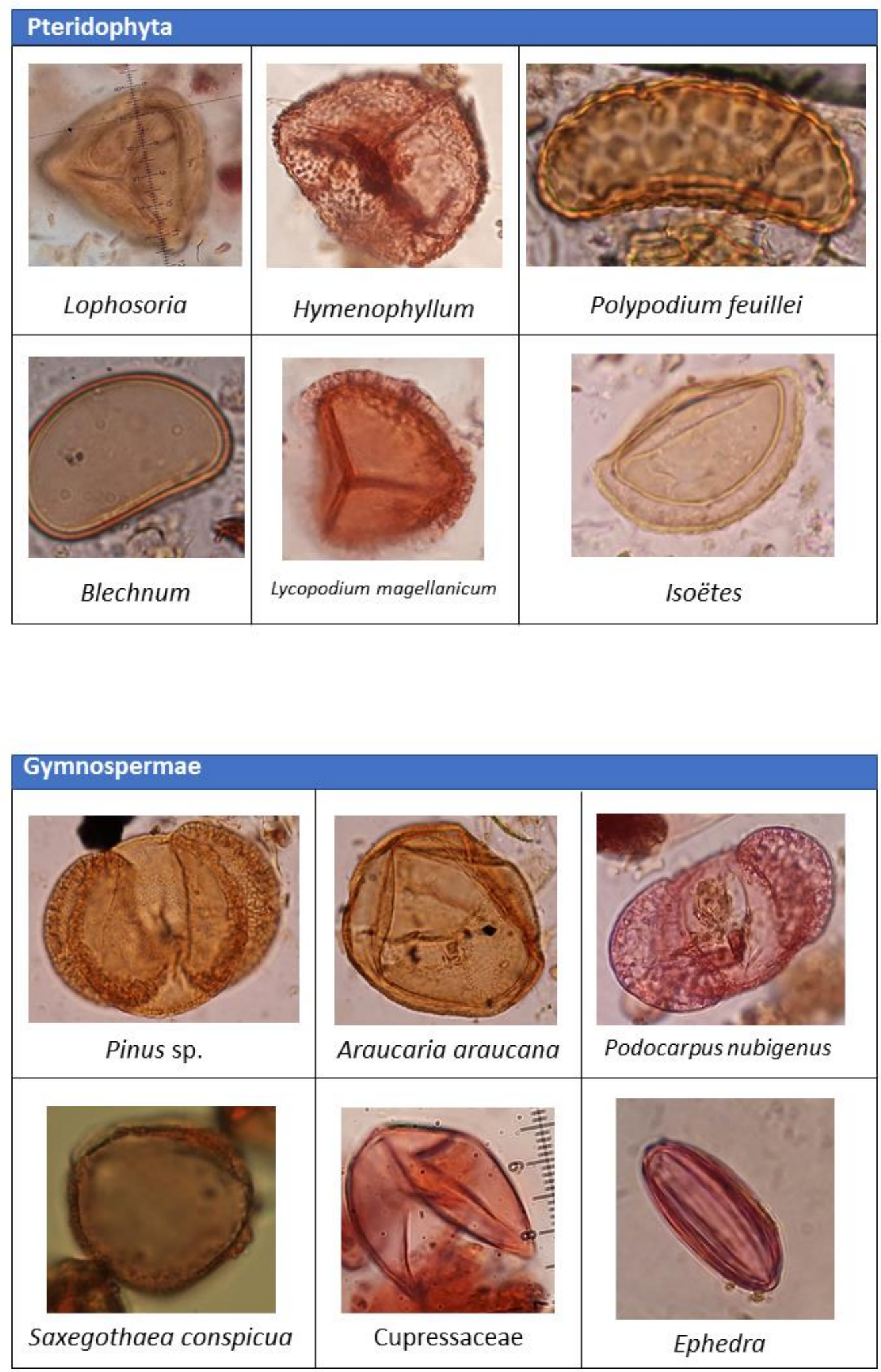

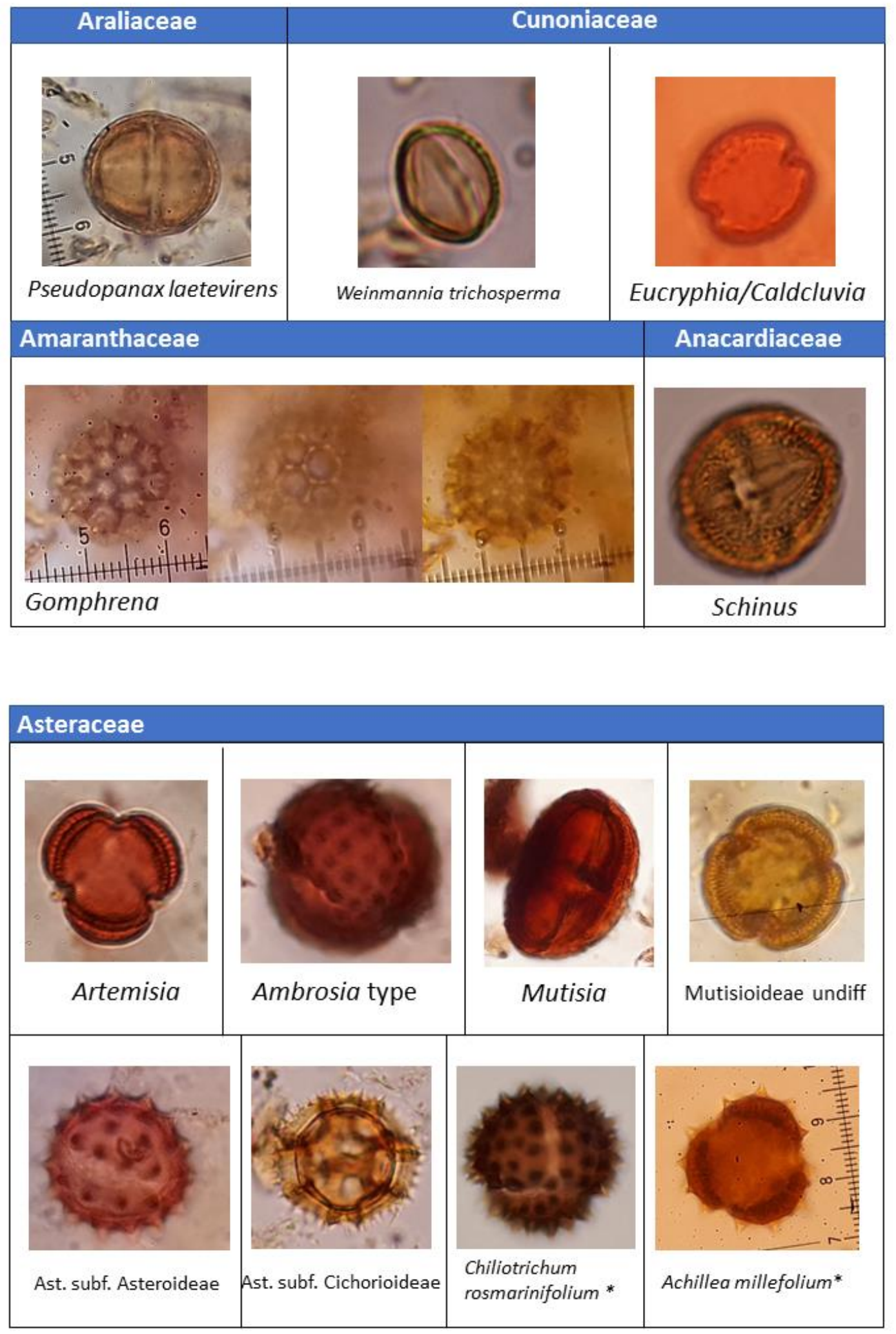


\begin{tabular}{|c|c|}
\hline Celastraceae & Alismataceae \\
\hline Maytenus & Sagittaria chilensis* \\
\hline Chenopodiaceae & Caryophyllaceae \\
\hline & \\
\hline & \\
\hline
\end{tabular}

\begin{tabular}{|c|c|}
\hline Griseliniaceae & Brassicaceae \\
\hline Griselinia type & \\
\hline Elaeocarpaceae & Ericaceae \\
\hline Aristotelia & \\
\hline (C) & \\
\hline
\end{tabular}



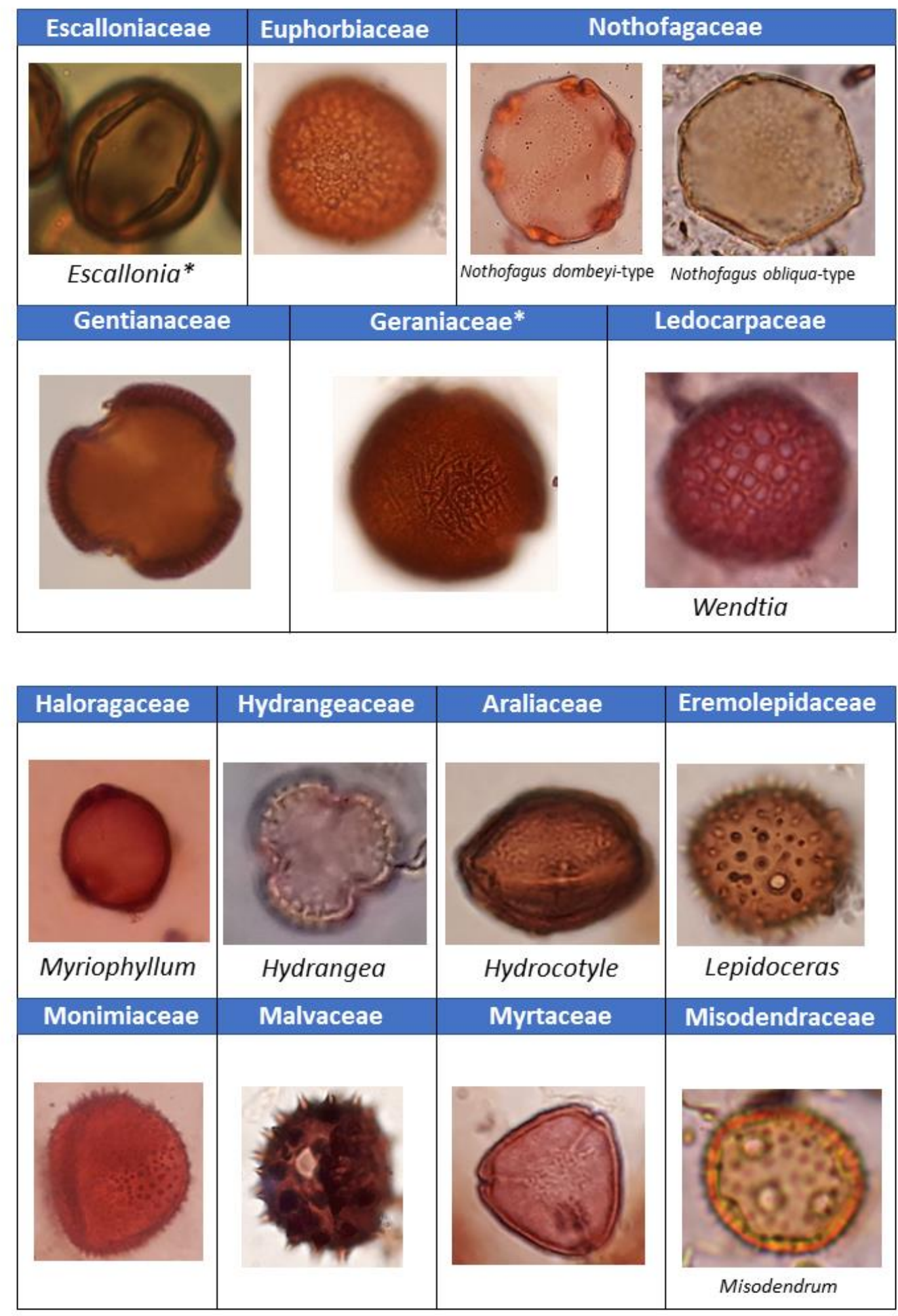

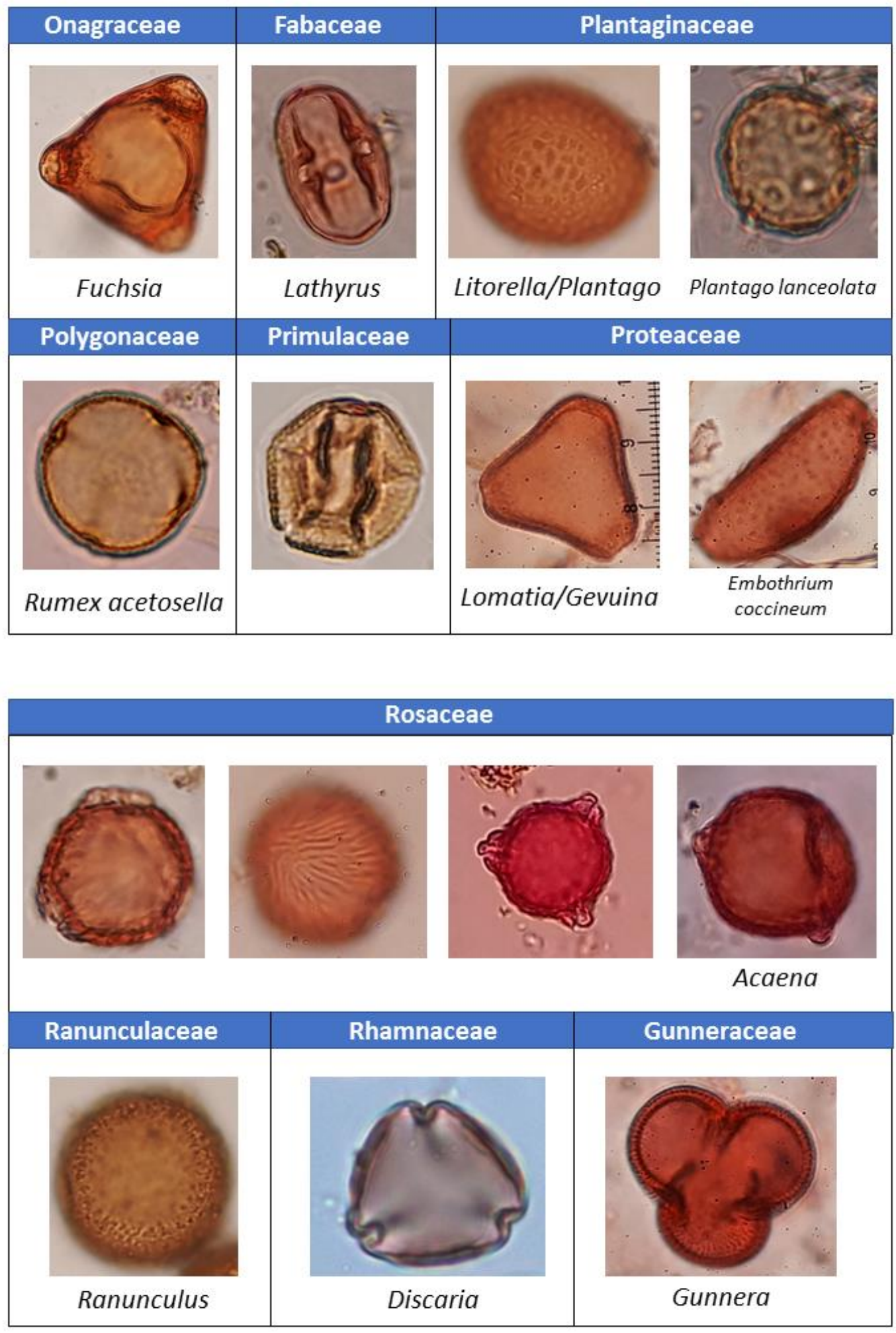


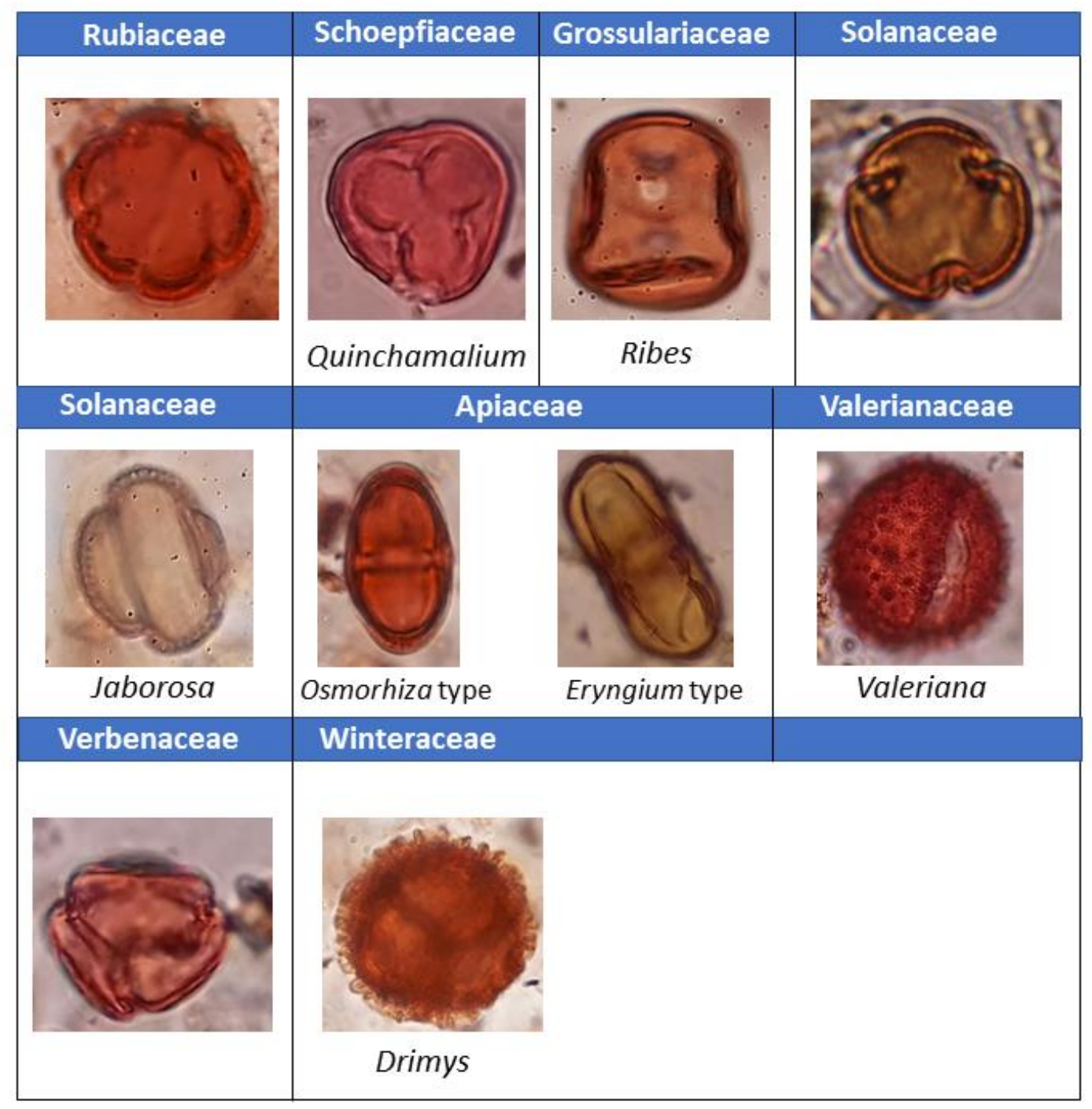




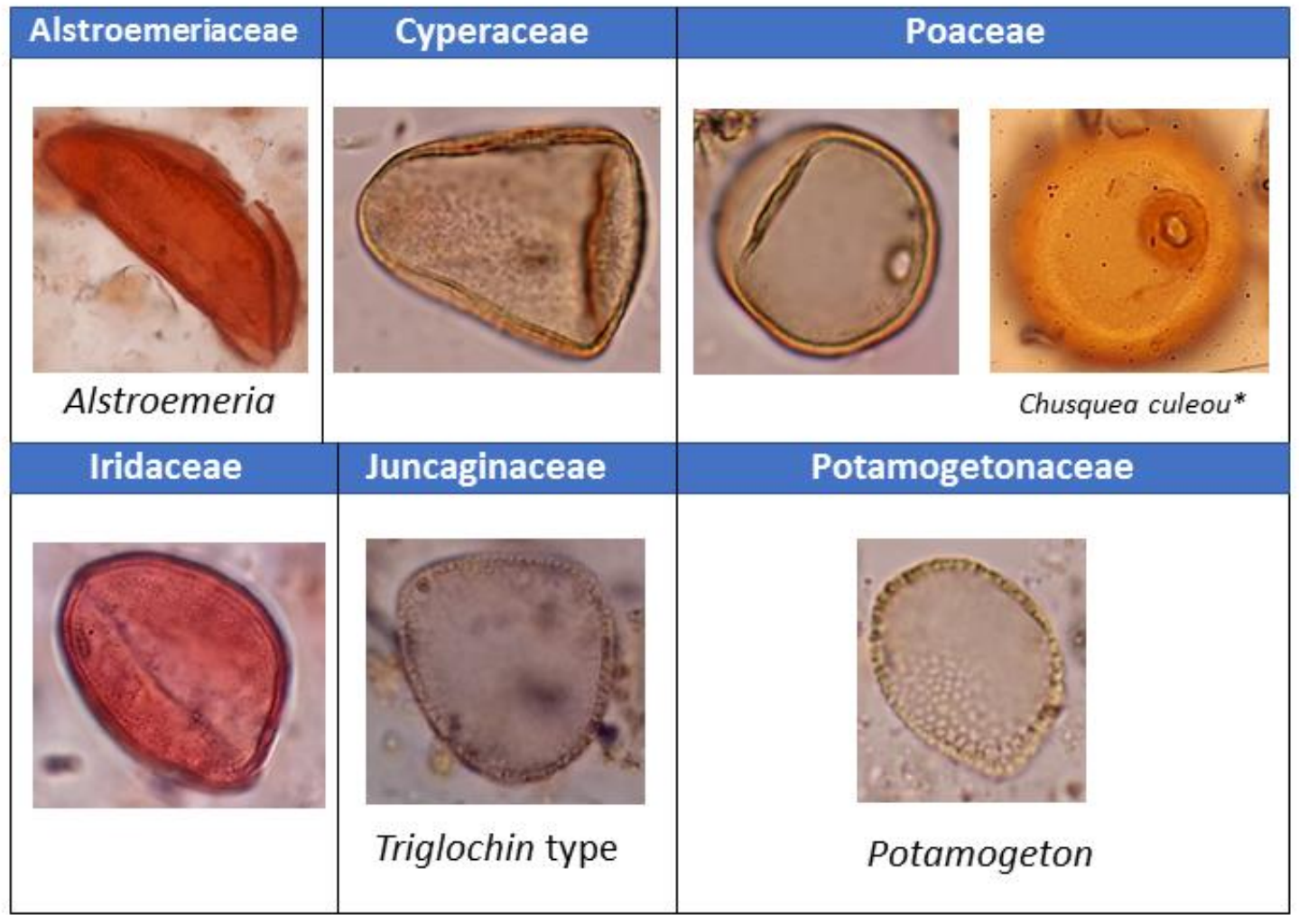




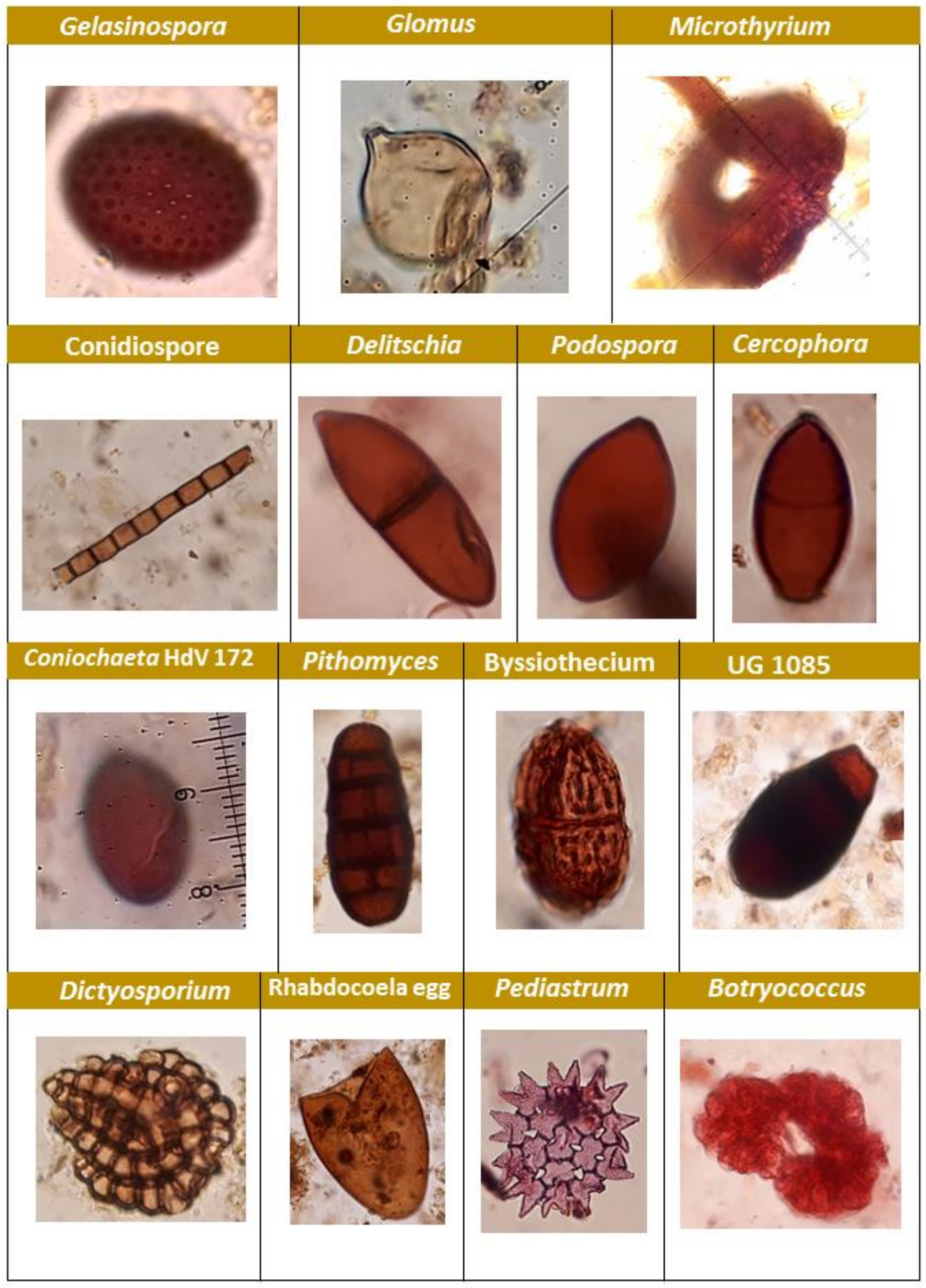




\section{Appendix 3}

Full pollen diagrams Bruja, Avutarda, and Vizcacha 
Full pollen diagram Bruja
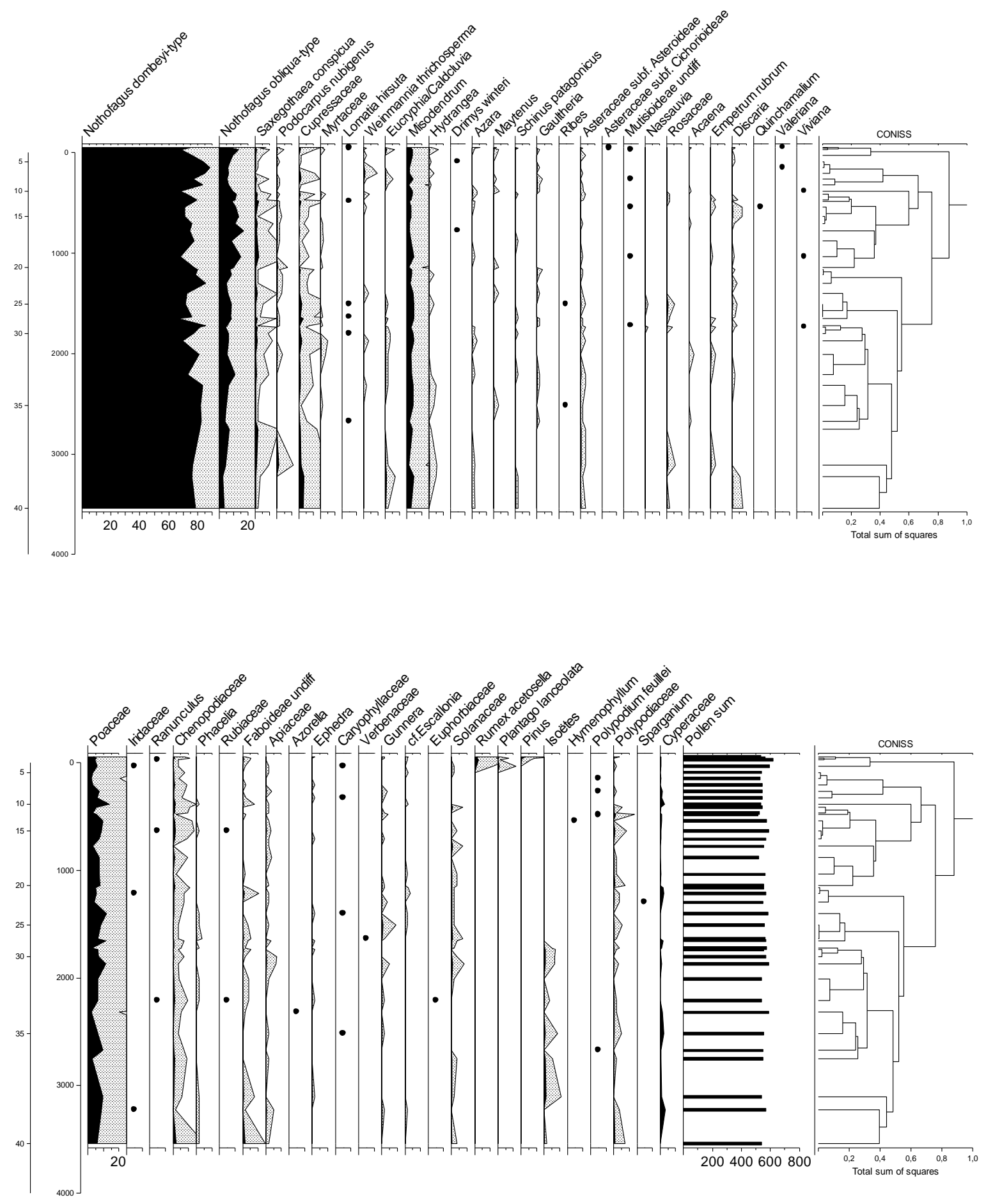
Full pollen diagram Avutarda
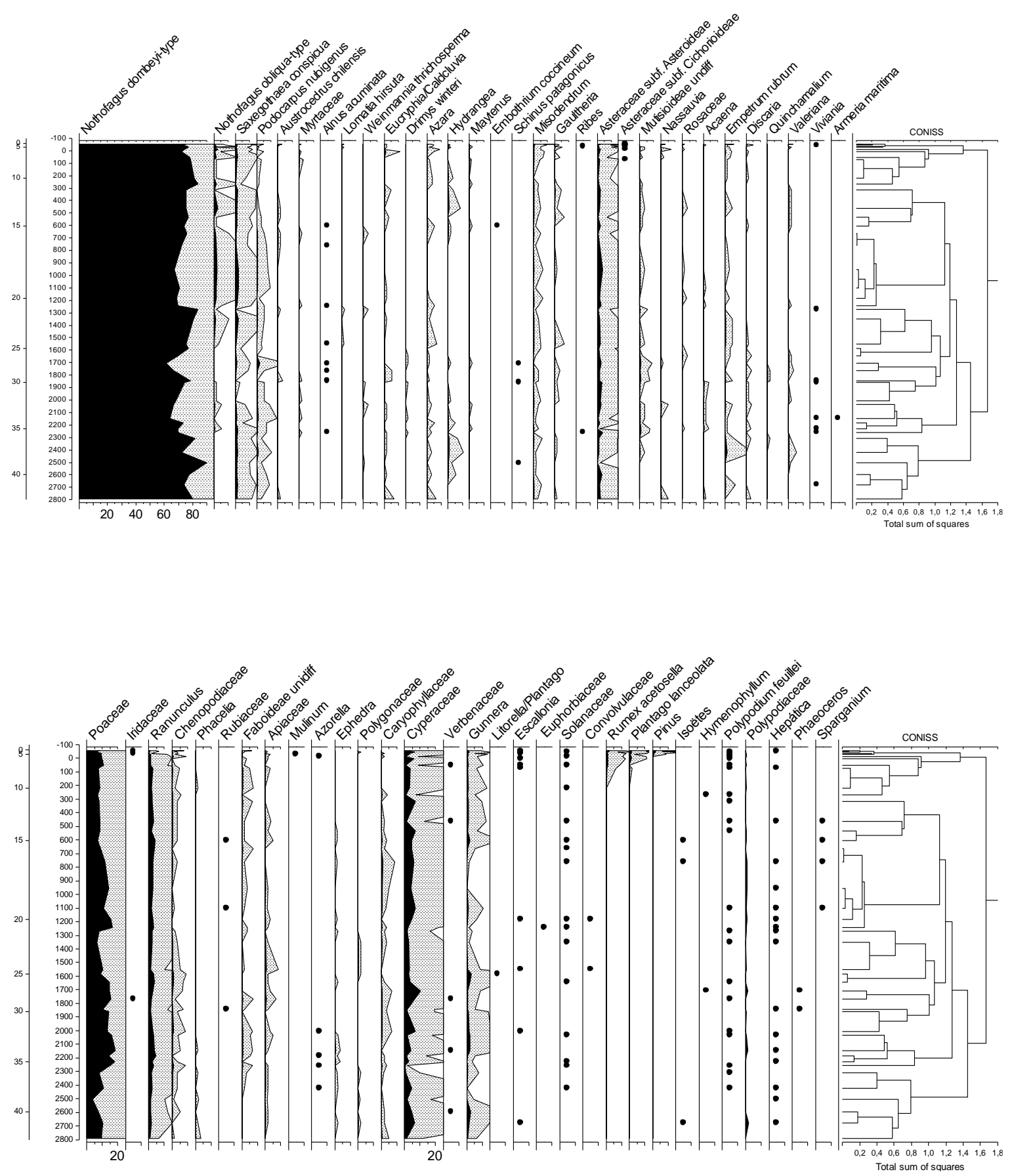
Full pollen diagram Vizcacha
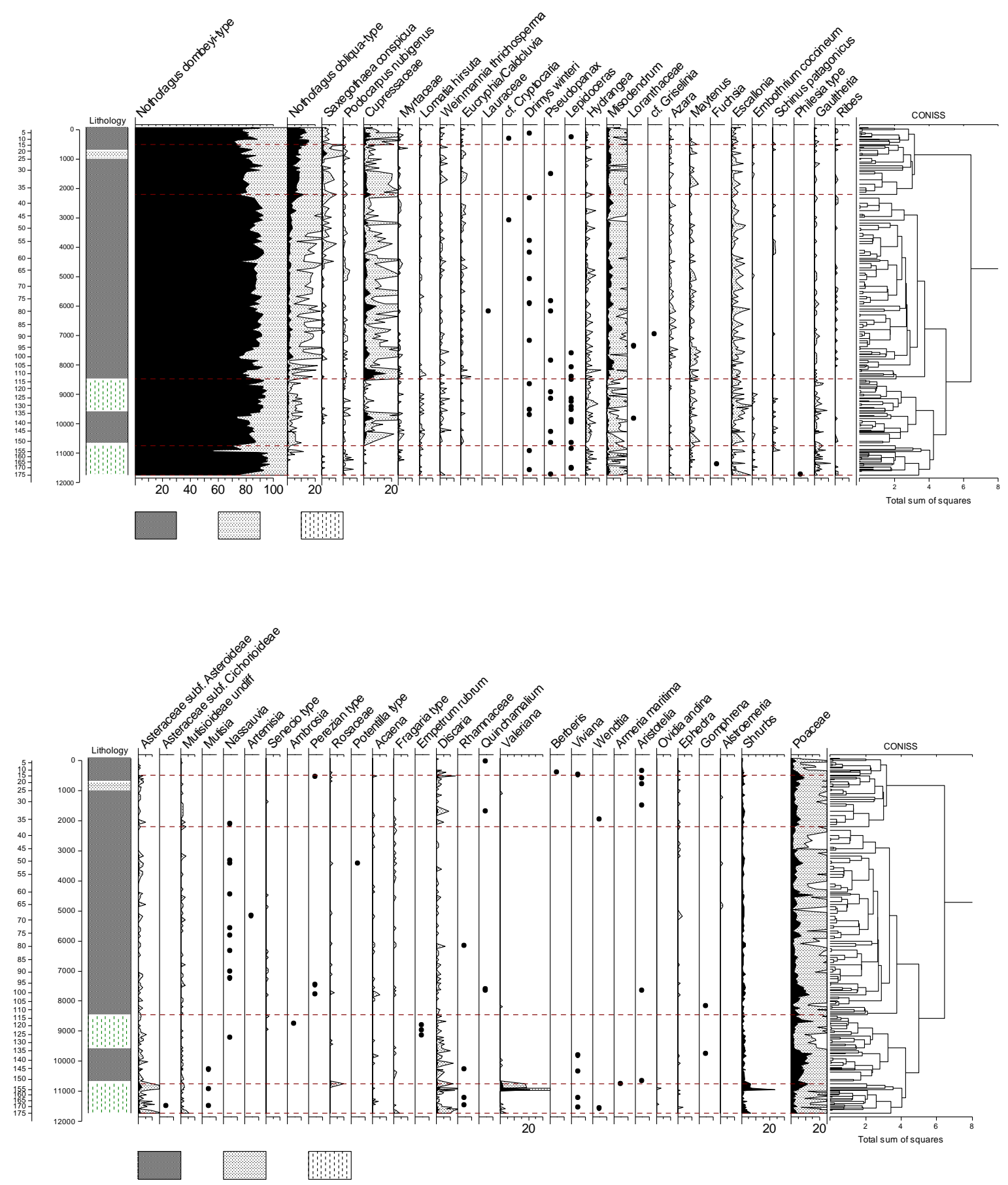

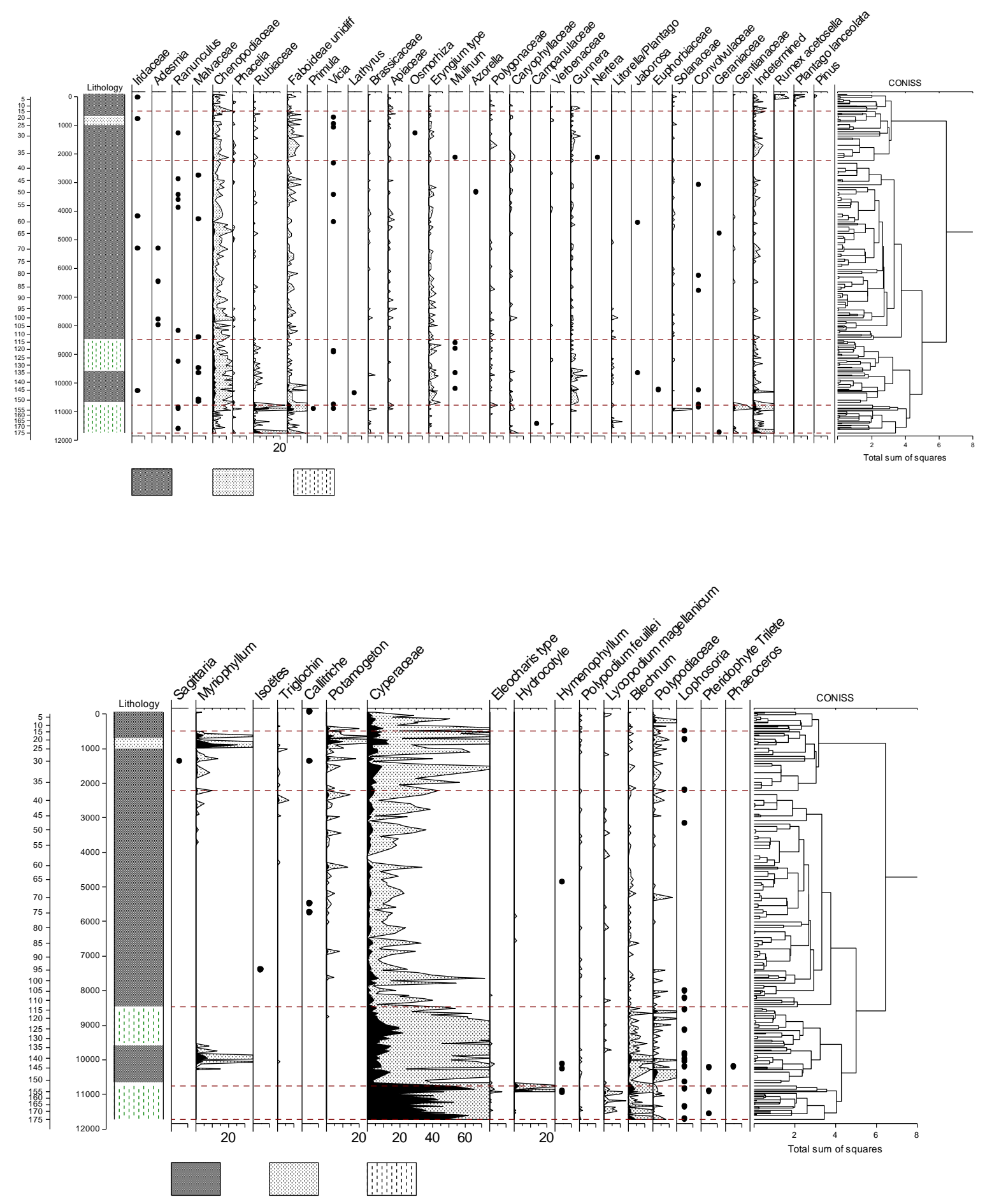


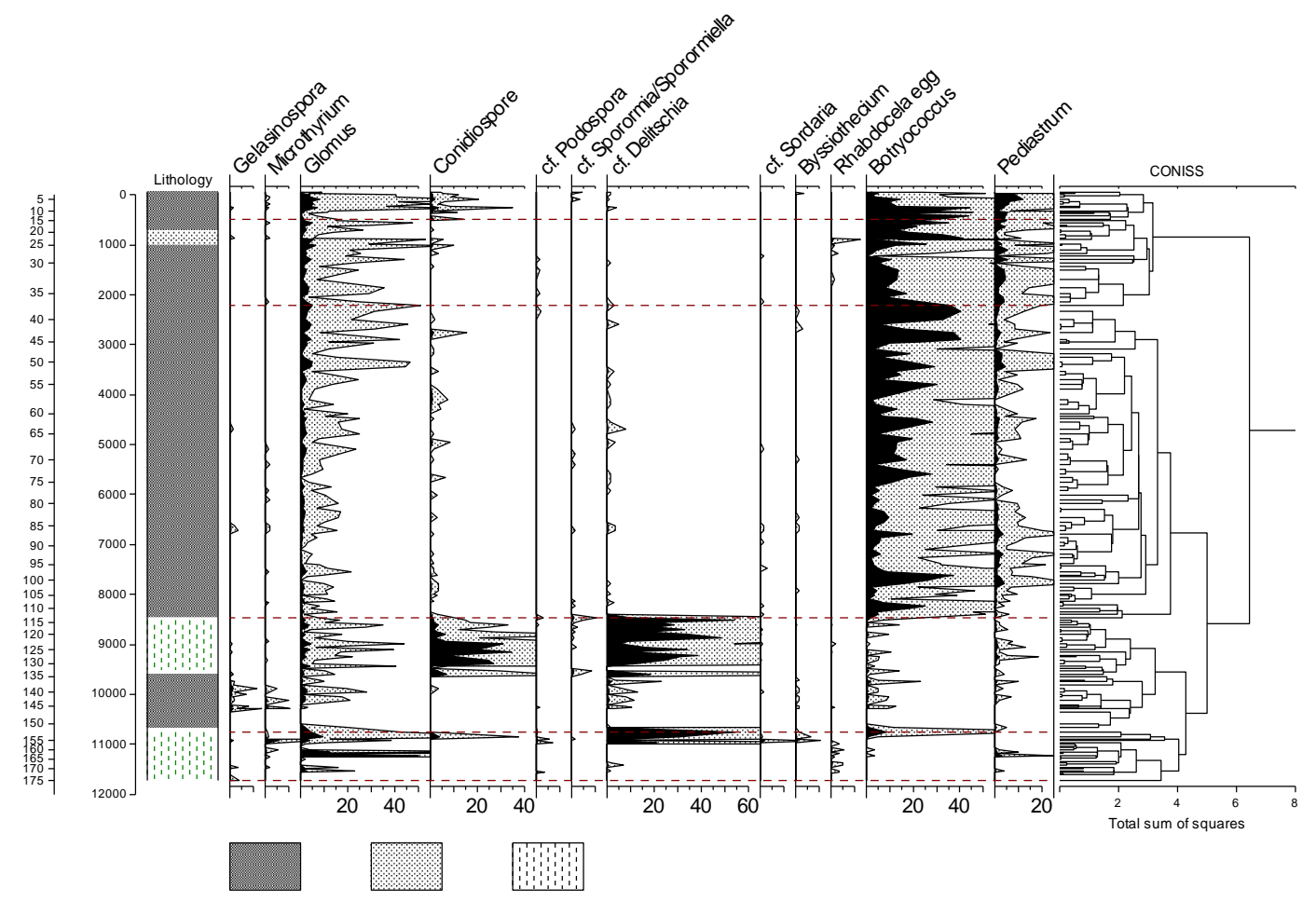

